Florida International University FIU Digital Commons

3-24-2014

\title{
Rethinking the National Question: Anti-Statist Discourses within the Kurdish National Movement
}

Ozum Yesiltas

Florida International University, oyesi001@fiu.edu

DOI: $10.25148 /$ etd.FI14040879

Follow this and additional works at: https://digitalcommons.fiu.edu/etd

Part of the International and Area Studies Commons, and the International Relations Commons

\section{Recommended Citation}

Yesiltas, Ozum, "Rethinking the National Question: Anti-Statist Discourses within the Kurdish National Movement" (2014). FIU

Electronic Theses and Dissertations. 1325.

https://digitalcommons.fiu.edu/etd/1325

This work is brought to you for free and open access by the University Graduate School at FIU Digital Commons. It has been accepted for inclusion in FIU Electronic Theses and Dissertations by an authorized administrator of FIU Digital Commons. For more information, please contact dcc@fiu.edu. 


\section{FLORIDA INTERNATIONAL UNIVERSITY \\ Miami, Florida}

\section{RETHINKING THE NATIONAL QUESTION: ANTI-STATIST DISCOURSES WITHIN THE KURDISH NATIONAL MOVEMENT}

A dissertation submitted in partial fulfillment of the requirements for the degree of DOCTOR OF PHILOSOPHY

in

INTERNATIONAL RELATIONS

by

Ozum Yesiltas 
To: $\quad$ Dean Kenneth Furton

College of Arts and Sciences

This dissertation, written by Ozum Yesiltas, and entitled Rethinking the National Question: Anti-Statist Discourses within the Kurdish National Movement, having been approved in respect to style and intellectual content, is referred to you for judgment.

We have read this dissertation and recommend that it be approved.

Felix Martin

Charles G. MacDonald

$\overline{\text { Benjamin Smith }}$

Mohiaddin Mesbahi, Co-Major Professor

Rebecca Mae Salokar, Co-Major Professor

Date of Defense: March 24, 2014

The dissertation of Ozum Yesiltas is approved.

$\begin{array}{r}\hline \begin{array}{r}\text { Dean Kenneth G. Furton } \\ \text { College of Arts and Sciences }\end{array} \\ \hline \begin{array}{r}\text { Dean Lakshmi N. Reddi } \\ \text { University Graduate School }\end{array}\end{array}$

Florida International University, 2014 
(C) Copyright 2014 by Ozum Yesiltas

All rights reserved. 


\section{DEDICATION}

I dedicate this dissertation to my family and colleagues at Florida International University without whose generous emotional and intellectual support it would not have come to fruition. 


\section{ACKNOWLEDGMENTS}

I wish to thank all members of my committee for patiently and smoothly guiding me throughout the research and writing phases of the present work. Special gratitude should go to Dr. Mohiaddin Mesbahi whose intellectual brilliance, generous mentorship, and inspiring lectures have been at the genesis of the present work and have guided it throughout. I would also like to thank Dr. Felix Martin, Dr. Charles G. MacDonald and Dr. Benjamin Smith for providing invaluable guidance and inspiring works and words.

I am particularly grateful to my parents Muzaffer Yeşiltaş and Ayten Yeşiltaş and my brother Yalın Yeşiltaş for their inexhaustible patience and great understanding whenever I need.

The Dissertation Evidence Acquisition Fellowship and the Dissertation Year Fellowship provided by the Graduate School of Florida International University during the fieldwork and writing phases of this dissertation are gratefully acknowledged. 


\title{
ABSTRACT OF THE DISSERTATION \\ RETHINKING THE NATIONAL QUESTION: ANTI-STATIST DISCOURSES \\ WITHIN THE KURDISH NATIONAL MOVEMENT
}

\author{
by \\ Ozum Yesiltas \\ Florida International University, 2014 \\ Miami, Florida \\ Professor Mohiaddin Mesbahi, Co-Major Professor \\ Professor Rebecca Mae Salokar, Co-Major Professor
}

Why and under what conditions have the Kurds become agents of change in the Middle East in terms of democratization? Why did the Kurds' role as democratic agents become particularly visible in the 1990s? How does the Kurdish movement's turn to democratic discourse affect the political systems of Turkey, Iran, Iraq and Syria? What are the implications of the Kurds' adoption of democratic discourse for the transnational aspect of the Kurdish movement?

Since the early 1990s, Kurdish national movements in Turkey, Iran, Iraq and Syria have undergone important political and ideological transformations. As a result of the Kurds' growing role in shaping the debates on human rights and democratization in these four countries, the Kurdish national movement has acquired a dual character: an ethno-cultural struggle for the recognition of Kurdish identity, and a democratization movement that seeks to redefine the concepts of governance and citizenship in Turkey, Iran, Iraq and Syria. The process transformation has affected relations between the Kurdish movements and their respective central governments in significant ways. 
On the basis of face-to-face interviews and archival research conducted in Turkey, Iraq and parts of Europe, the present work challenges the current narrative of Kurdish nationalism, which is predominantly drawn from a statist interpretation of Kurdish nationalist goals, and argues instead that the Kurdish question is no longer a problem of statelessness but a problem of democracy in Turkey, Iran, Iraq and Syria.

The main contributions of this work are three fold. First, the research unfolds the reasons behind the growing emphasis of the Kurdish movement on the concepts of democracy, human rights, and political participation, which started in the early 1990s. Second, the findings challenge the existing scholarship that explains Kurdish nationalism as a problem of statelessness and shifts the focus to the transformative potentials of the Kurdish national movement in Turkey, Iran, Iraq and Syria through a comparative lens. Third, this work explores the complex transnational coordination and negotiations between the Kurdish movements across borders and explains the regional repercussions of this process. 


\section{TABLE OF CONTENTS}

CHAPTER

PAGE

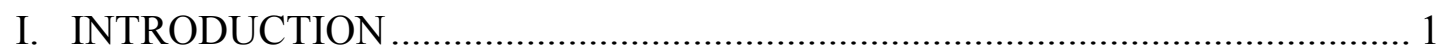

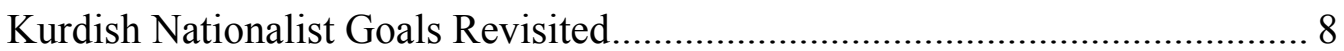

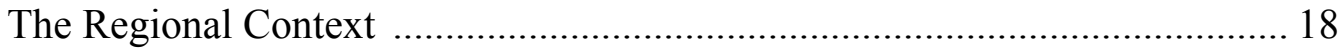

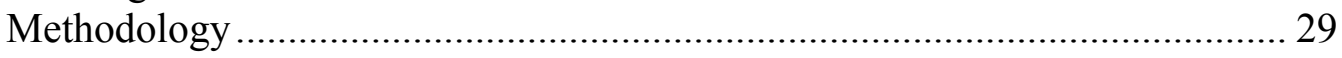

II. THEORETICAL FOUNDATIONS OF KURDISH NATIONALISM ………...... 37

Modernists vs. Ethnicists: A False Dichotomy? ................................................ 39

The Limits of an Emerging Theoretical Synthesis ........................................... 46

Structural Approaches to the Study of Kurdish Nationalism............................. 52

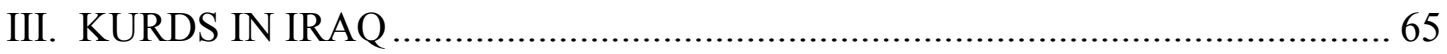

The Road to Autonomy: The Legacy of the Armed Struggle............................ 70

Autonomous Kurdistan: An Opportunity for Democracy …………………..... 80

Political Development and Emergent Democracy in Iraqi Kurdistan ............... 85

Relations between the KRG and Baghdad in the Post-Saddam Era ................. 96

The Arab-Kurdish Divide: Challenges and Prospects ...................................... 98

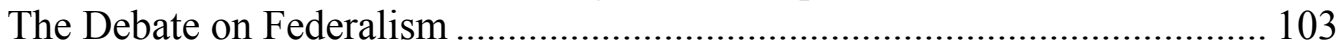

Democracy and Power-Sharing in Iraq: Towards an Alternative Model ....... 108

The Road Ahead .................................................................................... 116

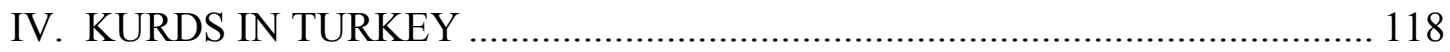

The Ideological Foundations of the Kurdish Movement in Turkey ............... 121

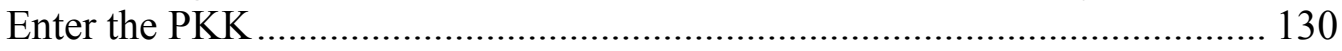

The Rise of Political Violence ....................................................................... 136

Transformation of the Kurdish Movement in Turkey...................................... 143

The PKK's Turn to Democratic Discourse ........................................................ 153

The Justice and Development Party and the Kurdish Question....................... 159

The Democratic Opening and the Oslo Process …………………................. 166

The Limits of the AKP's Kurdish Policy ...................................................... 170

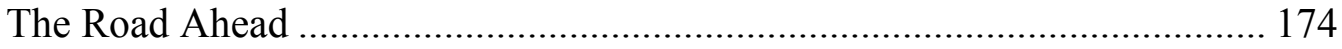

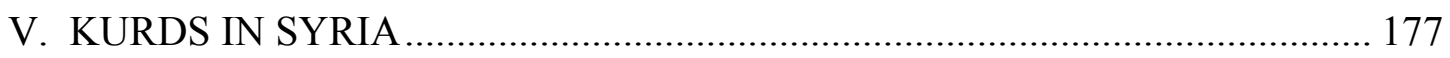

Institutionalization of Kurdish Nationalism in Syria ..................................... 180

Hafez Al-Assad's Game ............................................................................. 184

Reawakening of Kurdish Nationalism in Syria ............................................. 189

Towards the Qamishli Revolt .................................................................... 191

The Beginning of a New Era: The Qamishli Revolt....................................... 197

Evolving Relations between The Kurdish and Arab Opposition...................... 201

Syria: The Arab Spring's Final Destination ................................................... 211 
The Kurds and the Syrian Opposition in the Wake of the Syrian Uprising.... 213

Establishment of the Syrian Kurdish National Council............................... 218

The Role of the Democratic Union Party ....................................................... 223

Intra-Kurdish Party Relations ........................................................................ 229

The Role of the Regional Actors in the Syrian Uprising .............................. 233

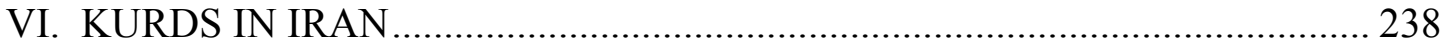

The Status of Ethnic and Religious Minorities in Iran ................................. 241

The Legacy of the Republic of Mahabad................................................... 250

The Kurds and the State After the Islamic Revolution ................................ 257

Towards the First Wave of Reform ............................................................... 261

The Reform Movement and the Kurdish Challenge ...................................... 268

2009 Presidential Election and the Second Wave of Reform ......................... 276

The Kurds and the Iranian Opposition: New Horizons for Cooperation ......... 284

The International Dimension of the Kurdish Question in Iran ....................... 289

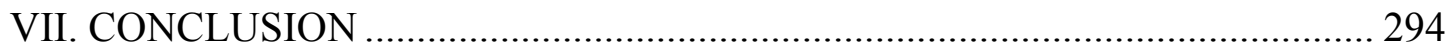

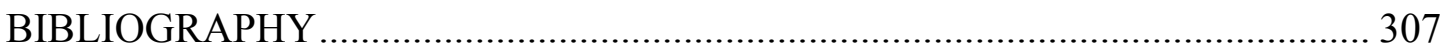

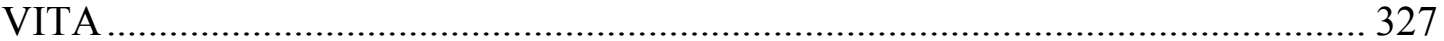




\section{ABBREVIATIONS AND ACRONYMS}

\begin{tabular}{|c|c|}
\hline AKP & Justice and Development Party \\
\hline BDP & Peace and Democracy Party \\
\hline $\mathrm{CHP}$ & Republican People's Party \\
\hline DDKD & Revolutionary Eastern Cultural Associations \\
\hline DDKO & Revolutionary Eastern Cultural Hearths \\
\hline DTK & Democratic Society Congress \\
\hline DTP & Democratic Society Party \\
\hline ECHR & European Court of Human Rights \\
\hline FSA & Free Syrian Army \\
\hline HADEP & People's Democracy Party \\
\hline HEP & People's Labor Party \\
\hline HPG & People's Defense Forces \\
\hline IKDS & Iran's Kurdistan Democratic Party \\
\hline KADEK & Kurdistan Freedom and Democracy Congress \\
\hline $\mathrm{KCK}$ & Council of Communities of Kurdistan \\
\hline KDP & Kurdistan Democratic Party \\
\hline KDPI & Democratic Party of Iranian Kurdistan \\
\hline KDPS & Kurdish Democratic Party in Syria \\
\hline KKK & Council of Associations of Kurdistan \\
\hline $\mathrm{KNC}$ & Kurdish National Council \\
\hline KRG & Kurdistan Regional Government \\
\hline KUK & National Liberationists of Kurdistan \\
\hline
\end{tabular}




\begin{tabular}{|c|c|}
\hline MHP & Nationalist Movement Party \\
\hline MIT & National Intelligence Organization \\
\hline $\mathrm{NCB}$ & National Coordination Body for Democratic Change \\
\hline PÇDK & Kurdistan Democratic Solution Party \\
\hline PJAK & Party of Free Life of Kurdistan \\
\hline PKK & Kurdistan Workers' Party \\
\hline PUK & Patriotic Union of Kurdistan \\
\hline PYD & Democratic Union Party \\
\hline $\mathrm{SCP}$ & Syrian Communist Party \\
\hline $\mathrm{SKC}$ & Supreme Kurdish Committee \\
\hline $\mathrm{SNC}$ & Syrian National Council \\
\hline TAL & Transitional Administrative Law \\
\hline TIP & Workers Party of Turkey \\
\hline TKDP & Kurdistan Democratic Party of Turkey \\
\hline TKSP & Turkish Kurdistan Socialist Party \\
\hline UAR & United Arab Republic \\
\hline YPG & People's Protection Units \\
\hline
\end{tabular}




\section{CHAPTER I}

\section{INTRODUCTION}

In Iraq, we are not struggling for independence, but for our liberty. We will continue our struggle until we obtain humane living conditions. Our struggle only serves for defending ourselves. The Arabs, with whom we commonly form the Iraqi State, have engaged in a battle to exterminate us. They denied our existence. We maintain this struggle to make ourselves recognized. ${ }^{1}$

In 1968, after seven years of fighting with the Iraqi army, this was the answer that Molla Mustafa Barzani gave to the Turkish journalist Hulusi Turgut who asked him about the Iraqi Kurdish movement's stance on the establishment of an independent Kurdish state in the Middle East. By the late 1960s, the Kurdish revolt in northern Iraq was viewed as a dangerous experiment of Kurdish self-rule by Baghdad as well as by Ankara, Tehran and Damascus. The emergence of the Kurdistan Workers' Party (PKK) insurgency in Turkey after roughly a decade further exacerbated the claims regarding the right and ability of the Kurds to run their own affairs and led to a great deal of discontent in the neighboring countries. These events left a major mark on the literature about the Kurds throughout the 1990s during which the question of Kurdish statehood intrigued a large number of scholars. Accordingly, the reasons behind the Kurds' historical failure to achieve statehood, their lack of political unity, and the cultural, political and economic suffering imposed by the host country policies upon the Kurdish populations in Turkey, Iran, Iraq and Syria have been widely discussed in the literature.

\footnotetext{
${ }^{1}$ Turgut, Hulusi (1969). Barzani Dosyası (Barzani File), Istanbul: Hasmet Matbaas1, 33-34.
} 
Although the Kurdish question has been predominantly studied in the context of the discourse of statehood both in the academic and policy circles, ${ }^{2}$ throughout the history of Kurdish struggle for national liberation, "independent statehood" was referred to only rarely by the major actors and political parties that shaped the Kurdish national movement in all four parts of Kurdistan. ${ }^{3}$ Although there has been a notable increase in Kurdish aspirations for independence at a mass level since the early 1990s, particularly following the emergence of Iraqi Kurdistan as a de-facto autonomous region, political independence was rarely stated explicitly at the elite level. Rather, the Kurdish demands were often defined within the framework of the broader term "the right to selfdetermination" with a focus on various decentralization projects, recognition of cultural rights and increased democracy in the host countries.

The acceptance of the constitution of 2005 in Iraq, which strengthened the position of the Kurdistan Regional Government (KRG) within both domestic and regional politics, introduced "federalism," a new administrative concept, with farreaching implications for both Iraq and the entire Middle East. ${ }^{4}$ On the other hand, as the struggle between young Turkish conscripts and Kurdish militants in the mountains of

\footnotetext{
${ }^{2}$ I am using the phrase "discourse of statehood" in the meaning of having an independent sovereign state defined as the exercise of organized political power, without intervention by a superior authority, over a territory and people (Baty 1930: 9-10). The existing scholarship approaches the "Kurdish question" predominantly as a problem of "statelessness" which is viewed as the root cause of the suppression and denial of the Kurds.

${ }^{3}$ Contemporary use of Kurdistan refers to large parts of eastern Turkey, northern Iraq, northwestern Iran and northeastern Syria. Kurdistan covers small portions of Armenia as well and may also include the Kurds living in Russia and Azerbaijan. The Kurds living in Russia, Armenia and Azerbaijan are not included in the present study mainly because of their insignificant numbers and marginal influence they have on their respective political environments.

${ }^{4}$ Ahmed, Mohammed M. A. (2007). "Laying the Foundation for a Kurdistani State in Iraq: 1991-2006" in The Evolution of Kurdish Nationalism edited by Mohammed M. A. Ahmed and Michael Gunter, Costa Mesa, CA: Mazda Publishers, 184.
} 
southeastern Turkey gradually moved into the more mundane settings of local government offices, the national parliament, and civic organizations since the early $1990 \mathrm{~s},{ }^{5}$ the pro-Kurdish political parties of Turkey have increasingly become the major locomotives of the internal policy debates on political decentralization, constitutional change and democratization in Turkey. Furthermore, as the so-called process of the Arab Spring has dramatically transformed the political landscape in the Middle East since late 2010, the Syrian Kurds have appeared as crucial actors in shaping both the future of Syria and the Kurdish question in general. As the terminology and focus dedicated to the recent political transformations in the Middle East remained largely "Arab" and little has been written over the role of non-Arab minorities have in shaping the future of the region, the Syrian Kurds' radical change of discourse from achieving citizenship and cultural rights to struggling for the establishment of a federal and democratic Syria has only enhanced the academic and policy significance of the Kurdish role in the Middle East.

In this context, the present work is an attempt to challenge the current narrative of Kurdish nationalism, which is predominantly derived from a statist interpretation of Kurdish nationalist goals, ${ }^{6}$ and to explore, instead, the Kurds' growing role in shaping the debates on governance, human rights and democratization in Turkey, Iran, Iraq and Syria. As opposed to the analyses of Kurdish nationalism from the viewpoint of the official state discourses, the present work is a deliberate effort to present the Kurdish viewpoint and focus on Kurdish nationalism as a movement in its own right and not just a reaction to the

\footnotetext{
${ }^{5}$ Watts, Nicole F. (2010). Activists in Office: Kurdish Politics and Protest in Turkey, Seattle, WA: University of Washington Press, 3-4.

${ }^{6}$ The "statist" interpretation of the Kurdish question refers to the notion that every nation is supposed to have a state of its own and that nationalism is mainly a struggle for maintaining or attaining statehood.
} 
processes of modernization and state-building in the Kurds' host countries. From this perspective, the Kurdish question is no longer defined as a problem of "statelessness," but a problem of "democracy" in Turkey, Iran, Iraq and Syria. Accordingly, I argue that Turkey, Iran, Iraq and Syria do not suffer from a "Kurdish problem," but rather a "democracy problem."

Analysis of the Kurdish question in the context of democratization in the Middle East is a recently developing subject of inquiry, yet the analyses that consider the Kurds as the "agents" of democratization remain relatively scarce. The literature does not offer any detailed study of the Kurds' role in the democratization processes in Iran or Syria. The studies that investigate the Kurdish role in Iraqi politics, on the other hand, usually have a stronger tendency to focus on the issues of partition or a possible Kurdish secession than to examine the Kurds as a force for the development of a democratically pluralistic Iraq. ${ }^{7}$ Since 2005, the establishment of a federal system in Iraq has led to the emergence of a growing literature on the issue of federalism and democratization in the Middle East. ${ }^{8}$ The pro-Kurdish democratic movement in Turkey has started to attract scholarly attention only recently. ${ }^{9}$ However, the major deficiency in these studies is that

\footnotetext{
${ }^{7}$ See Özcan, Nihat Ali (Spring 2004). "Could a Kurdish State Be Set Up In Iraq?,"Middle East Policy, 11 (1): 119-122; Rafaat, Araam (Fall 2007). "An Independent Kurdish State: Achievable or Merely a Kurdish Dream?," The Journal of Social Political and Economic Studies, 32 (3): 267-304; Dawoody, Alexander (2006). "The Kurdish Quest for Autonomy and Iraq's Statehood," Journal of Asian and African Studies, 41 (5-6): 483-505. For a discussion of the Iraqi Kurds' commitment to new forms of national affirmation beyond statehood see Salih, Khaled (Spring 2004). "Kurdish Reality in an Emerging Iraq," Middle East Policy, 11 (1): 122-126.

${ }^{8}$ See O'Leary, B., McGarry, J., Salih, K. (2005). The Future of Kurdistan in Iraq, Philadelphia: University of Pennsylvania Press; Stansfield, G., Anderson, E. (2010). Iraqi Kurdistan: Political Development and Emergent Democracy, London and New York: Routledge; Visser, R., Stansfield, G. (2007). Iraq of Its Regions: Cornerstones of a Federal Democracy?, New York: Columbia University Press.

${ }^{9}$ Demir, Eyüp (2005). Yasal Kürtler (Legal Kurds), İstanbul: Tevn Yayınları; Watts, Nicole F. (2010).
} 
although they discuss the demands raised by the pro-Kurdish political parties and the structural conditions that facilitate the emergence of pro-Kurdish legal activism, they do not present how those demands are articulated within the Kurdish movement's wider discourse of democratization and political change in Turkey and how they challenge the established notions of democracy and political representation.

Why and under what conditions do the Kurds become democratic agents? Why do the Kurdish demands become tied to the broader problem of democracy in Turkey, Iran, Iraq and Syria? Why do the Kurdish politicians argue that the problems of governance, democracy and human rights in these four countries are closely linked to the solution of their respective "Kurdish problem?" The existing scholarship is not well equipped to help answer those questions because of the emphasis placed on the independent state discourse, which is predominantly informed by a modernist understanding of nationalism and the tendency to view the nation as a social entity only insofar as it relates to a certain kind of modern territorial state, the nation-state. Driven by this particular theoretical stance, the Kurdish scholarship, more often than not, offers structural analyses of the issue that explores the trajectory of the Kurds either through modernist state discourses, that is, in terms of "failure" "lack" or "fragmentation" or through narratives of victimhood which treat the Kurdish case as a form of reactive nationalism that is shaped by the suppression and denial of Kurdish identity. This situation discounts the important changes the Kurdish movement has undergone over the last two decades and their impact on both domestic and regional politics. The present study aims to shift the attention to the proactive characteristics and transformative potentials of the Kurdish movement in the 
context of the debates on human rights and democratization in Turkey, Iran, Iraq and Syria since the early 1990 s.

Discussing the Kurdish national movement as a democratic agent and transformative force does not mean that Kurdish nationalists are a monolithic, unitary community whose strategies unfold similarly in every context. The Kurdish movements in Turkey, Iran, Iraq and Syria maintain quite distinctive internal dynamics in organizational, ideological and strategic terms. As emphasized numerously in the literature, Kurdish movements in each of the four countries in question act in diverse political environments, which largely affect how Kurdish nationalism is defined in each political context and what strategies are chosen to achieve the set goals. In this respect, the political structures of the Kurds' host countries play a major role in determining how the Kurdish political action is constrained and facilitated at different time frames and in various ways. ${ }^{10}$ However, while reacting to the constraints and opportunities they face, the Kurdish actors also affect and reshape the legal and institutional structures and political alignments within their respective polities in diverse ways. This situation creates a typically fluid, reciprocal and unpredictable relationship between the Kurdish movements and the political systems in which they act.

Nor does the focus of the present study on the anti-statist discourses ${ }^{11}$ within the Kurdish national movement serve to deny the Kurdish aspiration for statehood or to

\footnotetext{
${ }^{10}$ Natali, Denise (2005). The Kurds and the State: Evolving National Identity, New York: Syracuse University Press.

${ }^{11}$ The dictionary meaning of the prefix "anti" is "against", "hostile to" or "counteracting". However, I use the term anti-statist mainly to place an emphasis on the Kurdish political elite's articulation of the Kurdish demands outside the dominant paradigm that identifies nationalism with the goal of seeking sovereign statehood. In that sense, the purpose of using of the term "anti-statist discourses" is not to make a point that Kurdish national movement is against or hostile to the idea of a Kurdish nation-state.
} 
dismiss the discourse of independent statehood as a scholarly perspective in studying the Kurdish question. Rather, the purpose is to challenge the long-established perceptions regarding the Kurdish nationalism that has been continuously reproduced in the literature as a state-seeking movement. First, the concrete articulations of the Kurdish demands expressed through the statements of the Kurdish political elite do not match up to this narrative, and second, such an approach provides persistent ground for the regional states to legitimize their security-oriented policy making in dealing with the Kurdish question. Furthermore, this approach overlooks the complex and dynamic nature of the phenomenon of ethnic mobilization by over-emphasizing the host states' capacity and propensity for repression as factors that determine the rise and fall of cycles of Kurdish protest and political action, and considers the Kurdish movement simply as a phenomenon that derives from the negative and positive incentives offered by the Kurds' respective central governments.

The discourse of decentralization and cultural rights promoted by the Kurdish political elite has significant implications for the processes of democratization in Turkey, Iran, Iraq and Syria. Nevertheless, a statist reading of the Kurdish nationalist goals immediately eliminates the context through which these implications could be discussed. The statist approach deprives the Kurds of their agency and fails to capture the fluid and reciprocal relationship of Kurdish movements with their respective political systems. From this perspective, the Kurds' capacity to effect political change becomes exclusively tied to the establishment of a Kurdish nation-state whose absence, in turn, leads to a failure to undertake any serious accounting of movement-initiated changes in the political structures of the countries in which they live. 
The present work undertakes three tasks:

(1) Unpacking the reasons behind the growing emphasis, since the early 1990s, of the Kurdish movements on democracy, human rights, and political participation and explaining the new ways through which the notions of a united Kurdistan, Kurdish rights and independence were reinterpreted in the context of political change and the protection of territorial integrity in Turkey, Iran, Iraq and Syria.

(2) Challenging the work that restricts Kurdish nationalism as a reactive force against suppression and denial, and focusing instead on the transformative potentials of the Kurdish national movement by discussing movement-initiated legislative change and other forms of change designed to restructure the legal and institutional basis of the political systems in Turkey, Iran, Iraq and Syria.

(3) Explaining the complex transnational coordination and negotiations between the Kurdish movements in Turkey, Iran, Iraq and Syria as major factors that account for the still unfolding process of strategic convergence among the Kurdish political demands across borders, and investigating the regional repercussions of this process.

\section{Kurdish Nationalist Goals Revisited}

In 1970, while the negotiations between the commission headed by Saddam Hussein and Mullah Mustafa Barzani were still going on in order to settle the Kurdish issue in Iraq, Masoud Barzani, son of Mullah Mustafa Barzani, asked Saddam Hussein how Baghdad would solve the democracy problem in greater Iraq. Saddam Hussein said, 
"The system that we govern the rest of Iraq is none of your business. You will have autonomy in Kurdistan. Why do you care about this?"12

The 1970 autonomy agreement between Barzani's Kurdistan Democratic Party (KDP) and the Baath government did not lead to implementation of genuine autonomy in Iraqi Kurdistan. Nevertheless, Masoud Barzani’s question gained additional meaning after the 2003 American invasion of Iraq and became even more significant after the withdrawal of the U.S. forces at the end of 2011. As the centralization efforts of the Baghdad government, headed by Prime Minister Nouri Al-Maliki, increasingly caused friction between the KRG and Baghdad after the U.S. forces left Iraq, the political scenarios established on an approaching declaration of political independence by the KRG proliferated rapidly, while relatively little attention was paid to the policies of the Al-Maliki government as a threat to the unity of Iraq. ${ }^{13}$

The predictions concerning a possible Kurdish secession from Iraq have been compounded by the breakdown of authority in Syria after the start of the Syrian uprising in March 2011, and the creation of a Kurdish enclave along much of the country's border with Turkey by July 2012. As the Kurds have advanced in several Kurdish-populated towns and cities in northern Syria, a potential union of the Kurdistan region in northern Iraq with the Kurdish territories in Syria around the common cause of an independent

\footnotetext{
${ }^{12}$ Galbraith, Peter (2006). The End of Iraq: How American Incompetence Created a War Without End, New York: Simon and Schuster, 63.

${ }^{13}$ For the centralization policies of the Maliki government and the resulting conflict between the KRG and Baghdad see Özpek, B. B. (Summer 2012). "Democracy or Partition: Future Scenarios for the Future of Iraq," Insight Turkey, 14 (3): 127-140; Stansfield, G., Anderson, L. (Spring 2009) "Kurds in Iraq: The Struggle between Baghdad and Erbil,"Middle East Policy, 16 (1): 134-145.
} 
Kurdish state quickly came on to the agendas of the scholarly communities as well as the political analysts. ${ }^{14}$

Despite the considerable attention paid to the discourse of independent statehood in the political analyses concerning the Kurdish question, there is a significant mismatch between the focus of these analyses and how the Kurdish politicians articulate their demands in public sphere. Twenty years after Masoud Barzani's question to Saddam Hussein, in 1991, the Persian Gulf War triggered another Kurdish uprising in the north of Iraq. Following the uprising, Barzani explained the goal of the Kurdish movement with the motto, "Autonomy for Kurdistan, democracy for Iraq."

At this stage in our struggle, what we want is clear: We want real autonomy in Kurdistan and democracy for Iraq. However, our struggle in Iraqi Kurdistan is also part of the Kurdish movement in general. It's inevitable for the Kurdish nation to obtain its legitimate rights like all the other nations. Through what stages would this become a reality? How our struggle would progress in time would determine that. ${ }^{15}$

Although many scholars regarded the KRG as a de facto state, ${ }^{16}$ Barzani continued to underscore the Kurds' commitment to a unified Iraq after the autonomous status of the Kurdistan region gained constitutional recognition in 2005. In 2012, when the centralization policies of the Maliki government started to deepen the tensions

\footnotetext{
${ }^{14}$ See Mansour, Renad. "The Role of Iraqi Kurdistan in the Syrian-Kurd Pursuit of Autonomy," Aljazeera Center for Studies, September 19, 2012; Arango, Tim. "Kurds Prepare to Pursue More Autonomy in a Fallen Syria," New York Times, September 19, 2012; Weiss, Stanley. "It's Time for an Independent Kurdistan," Huffington Post, November 5, 2012; Cafiero, Giorgio. "The Dreams and Dilemmas of Iraqi Kurdistan," Foreign Policy in Focus, January 24, 2012.

${ }^{15}$ Ball, Rafet (1991). Kürt Dosyası (Kurdish File), İstanbul: Cem Yayınevi, 444-445.

${ }^{16}$ See Romano, David (2010). "Challenges of Autonomy in the Wake of U.S. Withdrawal," International Affairs, 86 (6): 1345-1359; Gunter, M. (2011). "Arab-Kurdish Relations and the Future of Iraq," Third World Quarterly, 32 (9): 1623-1635.
} 
between Baghdad and Erbil, Barzani reiterated the KRG's commitment to the unity and integrity of Iraq provided that Iraq remains federal and democratic:

Unfortunately, after many years the situation is being changed and turned into the previous version. We don't accept the return of dictatorship and we are only partner in governance by name. We cannot accept Kurds or any other community to be marginalized. The problem here is not only the Kurds, it is with all Iraq. If Iraq was democratic, federal and plural then it will be one and united. We don't threaten the unity of Iraq; it is dictatorship that threatens the unity of Iraq. ${ }^{17}$

The Kurdish question in Syria has usually been a marginal issue not only in the media but also in the academic research dedicated to either Syria or the Kurdish question. The Qamishli Revolt of 2004 marked the beginning of a new era for the Syrian Kurds by giving rise to a dramatic upsurge of Kurdish national feelings that shook the Syrian government and brought the Kurdish issue to the forefront of the debate about the future of Syria. ${ }^{18}$ However, the major breakthrough in Syrian Kurdish politics took place as a result of the spread of the uprisings known as the Arab Spring into Syria in March 2011, after which the prospects for greater Kurdish autonomy in the country became a crucial part of the discussions on how events should unfold after the toppling of the President Bashar al-Assad.

As of October 2011, a total of fourteen Kurdish parties exist in Syria and none of them formally demand an independent Syrian-Kurdish state or the inclusion of the Syrian

\footnotetext{
17 "President Barzani: We don't threaten the unity of Iraq; it is dictatorship that threatens the unity of Iraq" May 8, 2012. Available at http://www.malpress.com/english/news/302-president-barzani-we-dont-threatenthe-unity-of-iraq-it-is-dictatorship-that-threatens-theunity-of-iraq.html (Accessed June 4, 2012).

${ }^{18}$ Lowe, Robert (2007). "Kurdish Nationalism in Syria" in The Evolution of Kurdish Nationalism edited by Mohammed M. A. Ahmed and Michael Gunter, Costa Mesa, California: Mazda Publishers, 287.
} 
Kurdish regions in a united Kurdistan. ${ }^{19}$ On May 14, 2011, the Kurdish parties in Syria presented their demands publicly for the first time since the beginning of the uprising. Among the eight items listed as demands of the Kurds, one states that the solution of the Kurdish question in Syria can be achieved through "the implementation of a just and democratic solution to the Kurdish question by recognizing in the constitution that the Kurds are an integral part of the Syrian people and by guaranteeing their national rights. $" 20$

The same document also puts forward the position of the Kurds towards the broader minorities question in Syria, seeking "the protection and guarantee of the cultural rights of ethnic and religious minorities in Syria." 21

On June 11, 2012, a joint session of the Kurdish National Council and the People's Council of West Kurdistan, the two main Kurdish opposition groups in Syria, took place in Erbil, Iraq. The meeting led to the signing of a cooperation agreement on July 12, 2012, the Erbil Accords, which created the Kurdish Supreme Committee as a governing body of all Kurdish-controlled territories in Syria. The goal of the Committee was explained as follows:

... work towards the overthrow of the dictatorship in Damascus, the construction of a democratic, pluralistic state, and the creation of a new Syria with many ethnicities. This new Syria will satisfy the aspirations of

\footnotetext{
${ }^{19}$ KurdWatch (December 2011). "Who is the Syrian Kurdish Opposition? The Development of Kurdish Parties, 1956-2011,” Report 8, 13-15.

${ }^{20}$ KurdWatch Newsletter, May 23, 2011. http://www.kurdwatch.org/newsletter/newsletter_en_230511.html (Accessed February 12, 2012).

${ }^{21}$ Ibid.
} 
our people by recognizing its existence as an original people in the constitution. The Kurdish question must be solved democratically. ${ }^{22}$

As the Syrian Kurds buried their internal differences and gained control of several towns in northern Syria, the idea of decentralized rule as the most appropriate solution for the future of minorities in a post-Assad era became increasingly called for by the Kurdish leaders. This situation, combined with the ongoing conflict between the KRG and the central Iraqi government, has led to much speculation that the birth of an independent Kurdish state might be at hand.

Salih Muslim Muhammad, the leader of the most powerful Kurdish party in Syria, the Democratic Union Party (PYD), made the Kurdish position in Syria's revolution clear in a statement dated July 25, 2012:

We do not follow any separatist policies. We have no demand for independence. We want our demands to be fulfilled in the context of democratic rights and territorial integrity of Syria. We have been working on a project for four years which is based on the constitutional recognition of the Kurdish nation, and acknowledgement of their national rights such as education in mother tongue. We call this democratic autonomy. This project is not only for the Kurds but may be applied to all the other regions in Syria in case there is a consensus. ${ }^{23}$

After the joint session in Erbil, Shelal Keddo, a member of the Kurdish National Council, issued a statement declaring that federalism is the most viable and convenient solution for the Syrian issue in general and the Kurdish issue in particular:

Federalism could be considered a guarantee for the unity of Syrian land and preservation of the rights of each component of the Syrian

\footnotetext{
${ }^{22}$ Meeting Minutes of the Erbil Agreement, http://www.kurdwatch.org/pdf/KurdWatch_D027_en_ar.pdf (Accessed September 16, 2012).

${ }^{23}$ "PKK ile organik değil ideolojik bağ var" ("There is an ideological, rather than an organic bond, with the PKK"), BBC Turkish's Interview with the PYD leader Salih Muslim Muhammad. May 27, 2012. http://www.radikal.com.tr/Radikal.aspx?aType=RadikalDetayV3\&ArticleID=1095199\&CategoryID=81 (Accessed September 22, 2012).
} 
community. As it has been successfully achieved in many countries around the world, we should take the idea of federalism for Syria into consideration and study it seriously, and try to look into the possibilities of achieving it in order to prevent any potential civil war in the country after the collapse of the current tyrannical regime. ${ }^{24}$

Until today, the only major Kurdish organization that openly adopted the discourse of independent statehood with the goal of establishing a united Kurdish state as part of its official program is the Kurdistan Workers' Party (PKK), which has carried out armed struggle mainly in the southeastern Turkey since the late 1970s. Nevertheless, the PKK abandoned its objective of establishing an independent united Kurdish state by the early 1990s, and engaged in a comprehensive reorganization of its entire program throughout the 2000s, on the basis of democratic transformation in Turkey as the ultimate solution to the Kurdish question.

Since the capture, in 1999, of the PKK leader, Abdullah Öcalan, the discussion on the future of the Kurdish question in Turkey has shifted towards an alleged radical break in the PKK's objectives. The conventional view in the literature is that the PKK began to disintegrate and lost its way after the capture of Öcalan and gave up the ideal of an independent united Kurdistan. ${ }^{25}$ However, the political-ideological change PKK has undergone since the early 1990s was, in fact, more complex than a simple tactical retreat, and it has received very little recognition in the literature thus far. This situation played a significant role in the continuation of the "separatist" taboo surrounding the Kurdish

\footnotetext{
24 "Kurds See Federalism as Best Solution for Syria," Rudaw, August 17, 2012.

${ }^{25}$ Özcan (2006), for example, concludes that the PKK gave up the struggle for an independent Kurdistan after Öcalan's arrest. Likewise, Eccarius-Kelly (2011) explains the PKK's turn to democratic demands primarily by referring to Öcalan's capture in 1999. However, both the PKK dissidents and Öcalan himself have argued for a negotiated settlement of the Kurdish question in Turkey long before the arrest of Öcalan in 1999 (Beşikci 1992; Güneş 2012).
} 
question in Turkey and the persistent dominance of security-oriented policymaking within the state.

Öcalan refers to the "nation-state" mainly as an outdated model, and he sets forth an in-depth critique of the concept of state by arguing that liberation cannot be achieved by means of state-building, but rather by the deepening of democracy. In his defense texts, he particularly aims to disassociate democracy from nationalism, and independence from statehood, and he criticizes the national condition of modernity as exclusive and intolerant. Within this framework, Öcalan concludes the nation-state concept itself is antagonistic and destructive to the liberation of peoples, be they Kurdish or otherwise. He envisions a "democratic confederalism" in which numerous "self-governing bodies throughout Kurdistan" (all the territories where the Kurds live) operate through the autonomy of the citizens of local communities rather than state authorities. ${ }^{26}$ In that sense, he considers democratic confederalism not only a mechanism for the unification of Kurdistan and the Kurds, but also a model for the resolution of Middle East's problems originating from ethnic and religious differences.

The Kurdish experience in Iran, although it usually appears weaker than its counterparts in either Iraq or Turkey, is blessed with the fact that it was in Iran the first and only (to this date) independent Kurdish Republic, Mahabad, existed from 1945 to 1946. According to Nader Entessar, The Republic of Mahabad still stands as a beacon of light for Kurdish movements throughout the region. ${ }^{27}$ In September 1945, the Kurdistan

\footnotetext{
${ }^{26}$ Öcalan, Abdullah (2008). War and Peace in Kurdistan, Cologne: International Initiative Freedom for Öcalan - Peace in Kurdistan, 32.

${ }^{27}$ Entessar, Nader (1992). Kurdish Ethnonationalism, London: Lynne Rienner Publishers, 23.
} 
Democratic Party of Iran (KDPI) was established, replacing the Kurdish nationalist organization Komala that had been active since 1942. Two months after its formation, the KDPI issued a statement specifying its program of policies, and calling for "the Kurds to be free and independent in the management of their local affairs and to receive Kurdish independence within the borders of Persia." ${ }^{28}$

Shortly after the establishment of KDPI, on January 22, 1946, the Republic of Mahabad was proclaimed. According to its Manifesto, some of the aims of the Republic were mentioned as "autonomy for the Iranian Kurds within the Iranian state; the use of Kurdish as the medium of education and administration; and the election of a provincial council for Kurdistan to supervise state and social matters. ${ }^{29}$ Although the Republic of Mahabad was crushed by the central Iranian government in less than a year after its establishment, it is still considered as the first and only Kurdish republic in modern history and the most significant event in the imagination of all nationalist Kurds. Nevertheless, despite the Republic's ambiguous posture between autonomy and independence as well as the explicit demands for the recognition of the Kurds' cultural rights in Iran, the ultimate aims of the Kurdish Republic did not attract much scholarly attention. Instead of treating the Republic as a genuine effort by the Kurdish people to achieve their national rights within the framework of the Iranian state, the scholarly analyses that recount the history of the Kurdish Republic of 1946 explain it largely in

\footnotetext{
${ }^{28}$ Koohi-Kamali, Farideh (2003), The Political Development of the Kurds in Iran, New York: Palgrave Macmillan, 106.

${ }^{29}$ Entessar, 25.
} 
terms of the power politics of the Cold War era and as an extension of Soviet expansionist policy in the Persian Gulf. ${ }^{30}$

The KDPI continued to be the main vehicle of Kurdish political efforts in Iran in the following decades. The party mainly embraced the protection of the interests of the people of Kurdistan-Iran, and of all the national movements throughout Iran, as the main defining principle of its general course of action. Within this framework, autonomy for Kurdistan within a democratic Iran and the struggle for obtaining the national rights of all the oppressed peoples of Iran remained to be the party's principal objective until $2004 .^{31}$ In the $13^{\text {th }}$ congress of the party in July 2004 , the previous platform of "democracy for Iran, autonomy for Kurdistan" was replaced by the proclamation of federalism for Iran and national rights for the Kurds and other nationalities. ${ }^{32}$

An examination of the general goals of other prominent Kurdish parties in Iran does not indicate major programmatic differences. The Komala Party of Iranian Kurdistan places democracy as the main theme of its political agenda and identifies its mission as fighting for Kurdish rights, for a regime change in Iran, and for a democratic secular pluralist federal Iran. ${ }^{33}$ The Party of Free Life of Kurdistan (PJAK), which is a

\footnotetext{
${ }^{30}$ See Entessar (1992); Eagleton, William (1963). The Kurdish Republic of 1946, London: Oxford University Press; Koohi-Kamali, Farideh (2007) "The Kurdish Republic in Mahabad: Formation of a National Movement" in The Evolution of Kurdish Nationalism edited by Mohammed M. A. Ahmed, Michael Gunter, Costa Mesa, CA: Mazda Publishers. For a detailed theoretical and conceptual analysis of the formation and development of Kurdish nationalism in Iran from 1905 to 1947 see Vali, Abbas (2011). Kurds and the State in Iran: The Making of Kurdish Identity, London \& New York: I. B. Tauris \& Co Ltd.

${ }^{31}$ Ghassemlou, A. R. (1981). Report of The Central Committee to The Fifth Congress of The Kurdistan Democratic Party of Iran, Paris: PDKI, 28-29.

32 KDPI Program and Internal Regulations Adopted in the $13^{\text {th }}$ Congress, July 3-7, 2004. http://pdki.org/english/program-and-internal-regulation/ (Accessed October 2, 2012).

${ }^{33}$ Komala Party of Iranian Kurdistan, Party Program. http://www.komala/org/english/sidor/2011/2011/ Introduction_eindex.htm (Accessed October 3, 2012).
} 
relatively new party known for its active use of armed strategies since 2004, defines its goal as the establishment of a democratic organization of people as well as practice of the democratic values to achieve a radical type of democracy and to launch a democratic confederacy in eastern Kurdistan. ${ }^{34}$

\section{The Regional Context}

Besides the critical role the Kurdish movement plays in the domestic politics of Turkey, Iran, Iraq and Syria, particularly regarding these countries' paths towards meaningful democratization since the early 1990s, there has been also an emerging Kurdish dynamic at the regional level since the Gulf War of 1991. After the creation of an autonomous Kurdish region in northern Iraq, the Kurdish question has become an increasingly important issue in Middle Eastern and international politics. The war to remove Saddam Hussein from power in 2003 furthered this discussion. More recently, the uprisings in the Arab world unexpectedly pushed the Kurds to the forefront of regional politics after the breakdown of authority in Syria, which generated an unprecedented degree of unity and transnational cooperation among the Kurdish political groups.

Since the partition of Kurdistan in the aftermath of World War I, the aspirations of Kurdish people in one country have directly affected the aspirations and actions of the Kurdish populations across the borders. For several decades, the Kurds had to endure different socio-political circumstances and pressures in four different countries. However, despite the diverse political experiences and strategic trajectories followed by different

\footnotetext{
${ }^{34}$ Party of Free Life of Kurdistan, Party Program. http://pjak.org/eng/about.php (Accessed October 3, 2012).
} 
Kurdish groups in Turkey, Iran, Iraq and Syria, transnational politics have always been an integral part of Kurdish nationalism.

Relations between Syria and Iraq worsened significantly in the 1980s when Damascus sided with Iran during the Iran-Iraq war. Following that, the relations between the Kurdish parties, which were dominating northern Iraq, and the Syrian regime strengthened. The Syrian regime turned a blind eye to the recruitment of hundreds of Syrian Kurds to the ranks of peshmergas (Kurdish guerilla forces in Iraqi Kurdistan), mainly in Barzani's KDP. ${ }^{35}$ After the establishment of KRG in 1992, the economic stranglehold of a double embargo and the political isolation of the Iraqi Kurds made contacts with Damascus even more crucial for the Iraqi Kurdish political groups. The KDP and Jalal Talabani's Patriotic Union of Kurdistan (PUK) kept offices in the Syrian capital and in Qamishli until 2003, which allowed them to secure outside contacts. ${ }^{36}$

The tensions between Turkey and Syria derived from border disputes as well as conflicts over water supplies. Strained relations between the two countries pushed the Syrian regime to provide open support for the Kurdish nationalist movement in Turkey led by the PKK throughout the 1980s and 1990s. Öcalan, the leader of the PKK, lived in Syria for two decades until his arrest in 1999, and northern Syria became a major organizational ground for the PKK militants. Similar to the cross-border dynamics between the KDP, the PUK and the Kurds in Syria, considerable militant engagement by the Syrian Kurds in the ranks of the PKK also took place until the late 1990s.

\footnotetext{
${ }^{35}$ Tejel, Jordi (2009). Syria's Kurds: History, Politics, and Society, New York: Routledge, 72-73. ${ }^{36}$ Ibid. 74-75.
} 
Despite interruptions by regional power struggles, notably the Iran-Iraq war, the Kurdish nationalist parties of Iran and Iraq have traditionally supported each other. Particularly after the establishment of the KRG, cross-border contacts between the Iranian and Iraqi Kurdish communities increased through political party representations. Since the 1990s, Iranian Kurdish nationalist parties such as the KDPI and Komala have established offices and communication networks in northern Iraq to advance their nationalist claims. ${ }^{37}$ This enabled the Iranian Kurdish groups to not only coordinate activities with their supporters inside Iran, but to also engage in activities such as issuing press releases, training militants, and sponsoring military campaigns, actions that would otherwise have been prohibited in Iran. ${ }^{38}$

Similar to the literature on the relationship of the Kurdish movements to their respective central governments, the scholarly accounts of the transnational aspects of the Kurdish question also reflect the limits of adopting a structural/statist approach in explaining Kurdish political action at the regional level. Rather than providing an understanding of the strategies pursued by Kurdish political actors to gain leverage in the regional states, these accounts portray the Kurds as victims of regional power politics and essentially conclude that lack of political and cultural unity among the Kurds across borders made it easier for the host states to manipulate the Kurdish political groups according to their own domestic and regional interests.

\footnotetext{
${ }^{37}$ Natali, 177.

${ }^{38}$ Ibid.
} 
For example, Denise Natali argues that "asymmetrical transnational space ${ }^{39}$ has created greater complexity and diversification in Kurdish nationalist sentiment across borders. This diversification, alongside distinct historical trajectories that have emerged in conjunction with different states, limits the likelihood of a unified Kurdish nationalist project from emerging at the local, regional, or international level. ${ }^{, 40}$ Likewise, Abbas Vali asserts that because of the diversity of the general political and cultural processes of denial and exclusion of Kurdish identity in their respective national territories, Kurdish national identity has been deeply fragmented since its inception. ${ }^{41} \mathrm{He}$ argues that:

... the transnational ethos of Kurdish nationalism has its structural limitations in the internal conditions and diverse development of Kurdish societies. These conditions have seriously debased the transnational character of Kurdish nationalism, effectively undermining its centripetal tendencies .... Deprived of its structural, political and cultural unity, it is reduced to local autonomist movements riven with parochial interests and clientelist relations. ${ }^{42}$

... when they are patronized, maintained and used in cross-border politics by neighboring sovereign states against their own fragmented self, as is often the case in the region; the autonomist movements seriously obscure the political and cultural boundaries separating ethnic and national identities. $^{43}$

\footnotetext{
${ }^{39}$ Natali explains transnational space as the externally based opportunity structures such as diasporic networks, international nongovernmental organizations, host-country democratic systems, and advanced telecommunication system that provide new forms of support or constraints to Kurdish nationalist projects. By "asymmetrical transnational space" she refers to the uneven consequences of these processes for different Kurdish nationalist projects in different countries. She concludes that due to the asymmetrical nature of the transnational space, while Iraqi Kurds have gained a monopoly on Kurdish autonomy, their counterparts in Turkey and Iran have barely acquired political rights (Natali, 160-161).

${ }^{40}$ Ibid.

${ }^{41}$ Vali, Abbas (1998). "The Kurds and Their 'Others': Fragmented Identity and Fragmented Politics", Comparative Studies of South Asia, Africa and the Middle East, 18 (2): 82.

${ }^{42}$ Ibid.

${ }^{43}$ Ibid. 82-83.
} 
Although they principally recognized the cross-border character of the Kurdish question, these scholarly accounts primarily take the fragmentation of Kurdish society as their point of departure and conclude that the transnational space works "against" rather than "in favor" of the consolidation of Kurdish nationalist movement and leads to further diversification among the Kurdish political groups. Vali and Natali's discussion on the diverse development of Kurdish societies draws attention to the linguistic, religious, and tribal divisions among the Kurds that were deepened by the fragmentation of the Kurdish national movement after the post-World War I partition of Kurdistan. Nevertheless, while they focus on the Kurds' religious, tribal and linguistic differences and the distinct internal political conditions they had to face, these accounts do not take into consideration how the Kurds contest these local differences through the political discourses they develop both at the domestic and regional level. Since the 1990s, and particularly after the overthrow of Saddam Hussein's regime in Iraq in 2003, trans-border activities increasingly brought the Kurdish groups' political consciousness together around the overarching discourse of human rights, democracy and political decentralization. This common democratic discourse not only transcends the tribal, linguistic and religious divisions, but also creates a unified Kurdish political dynamic on a regional level that continues to develop alongside the separate Kurdish nationalist projects in Turkey, Iran, Iraq, and Syria.

In order to explain this discursive convergence among the separate Kurdish movements, one needs to move beyond a structural/statist approach to Kurdish nationalism. The argument that Kurdish movements in Turkey, Iran, Iraq and Syria followed distinct historical trajectories and were shaped by diverse processes of exclusion 
and denial contains much truth. Nonetheless, it falls short of shedding light on how the collective Kurdish entity is defined by the Kurdish political actors themselves and incorporated into the domestic as well as cross-border political engagements by the Kurdish groups in the contemporary period. Although the exact sense of "imagined community" could differ from one Kurdish community to another, it has been the common notion of membership rather a common understanding of what membership means that has throughout the history of Kurdish resistance, played an important role in sustaining the broader Kurdish movement, which encompasses Kurdish activists from multiple countries in the context of a complex transnational network.

The Syrian government's policy of providing Kurdish groups fighting against Turkey and Iraq with relative freedom of action from the 1970s onwards originated mainly from the regional ambitions of the Assad regime, which aimed to push its own Kurdish problem on to its neighbors. Accordingly, the PKK, KDP and PUK were allowed to pursue activities in Syria only on the condition they would keep the Syrian Kurdish movement under control. However, Hafiz Assad gradually lost control of his own game as a result of the strengthening of the Kurdish identity and Kurdish nationalist sentiments among the Syrian Kurds who were affected by the cultural and political activities of the PKK, KDP and PUK in Syria. This situation paved the way for the Syrian Kurds to eventually break out of their muted existence in the 1990s, and laid the foundation for the emergence of the Kurdish movement as an important political oppositional force in Syria by the early 2000s. This increasing political consciousness and organizational development among the Syrian Kurds from the 1990s onwards played a significant role 
in the swift organization of the Syrian Kurdish parties as a separate oppositional bloc during the Syrian uprising of 2011.

By the 1990s, transnational relationships among the Kurds also developed considerably as a result of the escalation of the PKK's activities in the region. As the traditional Iranian Kurdish political parties were mostly absent from Iranian Kurdistan, many Kurdish activists saw the PKK as an organization that could express their nationalist and revolutionary aspirations. ${ }^{44}$ After the arrest of Öcalan in February 1999, Kurdish demonstrators in Sanandaj, Mahabad and Urmiya took to the streets and staged mass protests against the Islamic regime in support of Öcalan. After the structural and ideological changes it experienced in the aftermath of Öcalan's capture, the PKK shifted its activities to include Iran and Syria by establishing independent political parties in these countries. The PJAK, which was established in 2004, soon attracted attention and showed considerable potential for organizing social and cultural activities and also for carrying out armed struggle against the Islamic regime. ${ }^{45}$ Likewise, the PYD, which was founded in Syria in 2003, strengthened its position as the successor of the PKK whose sphere of influence among the Syrian Kurds diminished after Damascus handed over Öcalan. Although the leaders of both PJAK and PYD emphasized on numerous occasions that they are distinct parties and have no organic ties to the PKK, both parties acknowledge they share the same leadership, membership and ideological orientation with the PKK.

\footnotetext{
${ }^{44}$ Ahmadzadeh, Hashem (2010). "Kurdish Political Mobilization in Iran" in The Kurdish Policy Imperative edited by Robert Lowe and Gareth Stansfield, London: Royal Institute of International Affairs, 189.

${ }^{45}$ Ibid. 189-190.
} 
There is no doubt the establishment of the KRG in Iraqi Kurdistan in 1992 increased the regional significance of the Kurdish question and inspired Kurds in other parts of Kurdistan in their search for autonomy and cultural rights. Given its concern for establishing working relationships with its neighbors, the KRG principally followed a cautious attitude towards the Kurdish militant groups fighting against the Turkish and Iranian governments. Although the KRG has been careful to distance itself from the PKK and PJAK in order not to antagonize Turkey and Iran, Iraqi Kurdistan continued to be a safe haven for various Kurdish groups including the Iranian Komala and KDPI.

Despite constant pressure from both Turkey and Iran to crackdown on the Kurdish groups operating in northern Iraq, the KRG traditionally avoided armed confrontation with these groups mainly because of the massive support base these groups have among the Iraqi Kurds. The regional government in northern Iraq was fragile and facing an uncertain future in the early 1990s, which was exacerbated by disastrous episodes of civil war between the KDP and PUK in the mid-1990s. Nonetheless, since the end of internal fighting in 1997, and particularly after the constitutional recognition of the KRG in 2005, both the KDP and PUK became more consistent in their statements about their support for a political solution to their neighbors' respective Kurdish problems and declared the regional government would not participate in military solutions.

While the academic discussions on the growing significance and legitimacy of Kurdish nationalism increased considerably after the Gulf wars of 1991 and 2003, these discussions led to the emergence of a perspective that reduces the regional dimension of the Kurdish question to the study of the autonomous status of the Iraqi Kurds and the politics of the KRG. Since the early 1990s, such a stance created a tendency to assign a 
primary status to Iraqi Kurdistan in order to explain the course of events of the Kurdish movements in Turkey, Iran and Syria and the cross-border character of the Kurdish issue.

Ofra Bengio states that:

... the traditionally marginalized Kurds of Syria have found new energy in the cauldron of the Syrian uprising and are now demanding a federal system in which they would gain significant autonomy in a post-Assad Syria. The extremely restive Kurds of Turkey are pressing for what they call democratic autonomy. The Kurds of Iran, typically unremarked upon in the media, are stirring beneath their blanket of obscurity. But most important of all these are the Kurds of Iraq. Iraq was the epicenter of the Kurds' great leap forward in the early 1990s: the establishment of the Kurdistan Regional Government (KRG), which is a euphemism for a de facto Kurdish state. It is to the KRG experience that Iranian, Syrian and Turkish Kurds increasingly look for lessons and guidance, and rightly so. ${ }^{46}$

In a similar vein, Jordi Tejel argues that:

The acceptance in the constitution in 2005 of federalism as the new Iraqi state's system of organization only served to strengthen the centrality of the Iraqi Kurds, both in Iraq and in the Kurdish arena in the Middle East. Almost immediately, demands for administrative autonomy following the Iraqi model were made with varying degrees of intensity in Turkey, Iran, and even Syria, confirming the cross-border character of the Kurdish issue. $^{47}$

It is true that the Kurdish autonomy in Iraq has become a major inspiration for Kurds in other parts of Kurdistan mainly because of the fact that the autonomy of the KRG has survived longer and been more meaningful than any other Kurdish autonomous experiment in recent history. ${ }^{48}$ However, it would be a misleading approach to consider this fact as grounds for assigning centrality to the Iraqi Kurds in analyzing the broader

\footnotetext{
${ }^{46}$ Bengio, Ofra (November/December 2012). "Will the Kurds Get Their Way?," The American Interest.

${ }^{47}$ Tejel. 80.

${ }^{48}$ Bengio, Ofra (2005). "Autonomy in Kurdistan in Historical Perspective" in The Future of Kurdistan in Iraq edited by Brendan O'Leary, John McGarry, and Khaled Salih, Philadelphia: University of Pennsylvania Press, 182.
} 
Kurdish phenomenon in the Middle East or to consider the Kurdish demands in Turkey, Iran and Syria as originating directly from the politics of the KRG. The growing international legitimacy enjoyed by Iraqi Kurdistan gave greater voice to the Kurdish cause in the international arena. Nevertheless, this situation also created an opportunity for the regional states to disregard their respective Kurdish problems by pursuing a policy of identifying the regional dimension of the Kurdish question solely with the developments concerning the status of Iraqi Kurdistan. Turkey, Iran, and Syria sought military and political support from the KRG for their policies towards the Kurdish movements within their own borders in exchange for granting recognition to the autonomous status of Iraqi Kurdistan. In other words, for Turkey, Iran and Syria, conducting diplomacy with the Iraqi Kurds emerged as a useful political strategy to increase their control over their respective Kurdish movements.

As rarely recognized in the literature, the demands for autonomy and cultural rights have been on the agenda of the Kurdish movement in Turkey since the early 1990s. The demand for democratic autonomy was officially declared for the first time in July 2011, and developed as a consequence of a complex ideological, strategic and organizational transformation of the Kurdish movement in Turkey that took place over the past two decades. Autonomy for Kurdistan within a democratic Iran, on the other hand, has been the core political concept of the Kurdish movement in Iran since the 1970s. Even the experience of the Mahabad Republic of 1946, which is often viewed as the symbol of Kurdish independence in the $20^{\text {th }}$ century, was in fact informed by a specific reading of the Iranian Constitution, which emphasizes political pluralism, 
decentralization of power, provincial and local administrative and cultural autonomy, and respect for religious and ethnic differences. ${ }^{49}$

The revival of the Kurdish movement in Syria was affected largely by the Kurdish experience in Iraq. According to one Syrian Kurdish political figure, the overthrow in 2003 of Saddam Hussein liberated the Syrian Kurds from a culture of fear and created a strong motivation for changing the status of the Kurds in Syria. ${ }^{50}$ However, it is often overlooked that besides the impact of the achievements of the Iraqi Kurds on the Kurds in Syria, there has also been a significant influence of the Kurdish movement in Turkey on the Syrian Kurds, particularly in ideological and organizational terms. Especially since the beginning of the Syrian uprising in March 2011, most of the popular representations of the events in Syrian Kurdish politics in media and scholarly accounts adopted a tendency to portray the situation as a battleground between the pro-PKK PYD and the pro-KRG Kurdish National Council. ${ }^{51}$ These accounts principally serve the goal of reinforcing the status of the KRG as the central force in Kurdish regional politics while marginalizing the influence of the PKK. Whereas, the Kurdish efforts to act as a united front in Syria and the KRG's mediating role, which included negotiations with the PYD at the risk of antagonizing Turkey, have received relatively little attention.

\footnotetext{
${ }^{49}$ Vali, Abbas (2011). 90.

${ }^{50}$ Mashal Tamo of the Kurdish Future Movement in Syria, quoted in Landis, Joshua, Pace, Joe (Winter 2006-2007). "The Syrian Opposition," The Washington Quarterly, 30, (1), 45-68.

${ }^{51}$ See Cafiero, Giorgio. "Who will Govern Syrian Kurdistan?," Foreign Policy in Focus, August 31, 2012; Ali, Othman. "The Struggle for the Hearts of Kurds in Syria: Barzani vs. Öcalan," Today's Zaman, February 13, 2012; Dinçer, O. Bahadır. "The Kurds in Syria, The PKK and Turkey," The Journal of Turkish Weekly, August 16, 2012; Natali, Denise. “Syria’s Kurdish Quagmire,” AlMonitor, May 1, 2012.
} 
The actions of the major Kurdish political actors in the Middle East, particularly the PKK, KDP and PUK, have been mostly evaluated from the perspective of the regional power struggles and the political ambitions of the states and international powers that affected the evolution of the Kurdish question. In this context, Kurds are often viewed as victims of changing power relationships among the regional states as well as the status-quo oriented approach of the international powers towards regional matters. Notwithstanding the significance of these factors in shaping the Kurdish politics in the Middle East, another crucial determinant of the regional dimension of the Kurdish question has been the diplomatic capacity of the Kurdish political groups themselves. These groups observe and review these regional power relations and position themselves as non-state actors vis-à-vis the regional, as well as international, actors in order to strengthen their political leverage and negotiating power. In this respect, incorporation of the "Kurdish viewpoint" into the regional debate on the Kurdish issue is another task that the present study undertakes.

\section{Methodology}

The present work is based on extensive archival research that incorporates a wide variety of primary and secondary sources. The sources were collected during a six-month period from multiple sites in Turkey, Iraq, parts of Europe and the United States. The written sources include Turkish, Kurdish and English language newspapers and periodicals; political party programs; parliamentary debates; newsletters published by various non-governmental organizations; human rights reports; municipal reports; policy papers published by think tanks; speeches and statements; election data; and personal memoirs. The documents were gathered from the National Library and Parliamentary 
Library (Ankara, Turkey); the Kurdistan Parliament (Erbil, Iraq); the political party offices of Peace and Democracy Party (Istanbul, Turkey), Kurdistan Democratic Party (Erbil, Iraq), Patriotic Union of Kurdistan (Sulaymaniah, Iraq), the Goran Movement (Sulaymaniah, Iraq), Islamic Movement of Kurdistan (Erbil, Iraq), Kurdistan Islamic Union (Erbil, Iraq); Bilkent University Library (Ankara, Turkey) and Salahaddin University Library (Erbil, Iraq); Kurdish Human Rights Watch (Erbil, Iraq); the Kurdish Human Rights Project (London, UK); the Kurdish Institute of Paris (Paris, France); Kurdistan Regional Government - Representation in the USA (Washington D.C., the US); internet web sites; and individuals.

Throughout the field work, I supplemented these written sources with in-depth interviews conducted with members of Parliament; party leaders; pro-Kurdish majors, journalists and lawyers; activists from human rights organizations; and representatives of think tanks and civil society organizations working in the field of Kurdish rights. I was not able to travel to Iran and Syria to collect archival data because of time constraints and personal safety concerns. To compensate for this deficiency, I conducted interviews with the leaders of the Syrian Kurdish opposition parties and the Democratic Party of Iranian Kurdistan in Erbil, Iraq, ${ }^{52}$ in order to gain first-hand information about the recent developments concerning the Kurdish movements in Iran and Syria.

All interviews were done face-to-face, directly by me in Turkish, English and Kurdish (with a translator available). The interviews were conducted to fill gaps in the existing literature, which predominantly views the Kurdish issue as a question of

\footnotetext{
${ }^{52}$ Since the beginning of the uprising in Syria, most of the Syrian Kurdish opposition parties are operating from northern Iraq. The Democratic Party of Iranian Kurdistan is outlawed in Iran. Its headquarters is located in Erbil, Iraq.
} 
statelessness and a case of reactive nationalism rather than a problem of democracy. In my attempt to depart from structural explanations that trace the evolutionary trajectory of the Kurds' history as one of victimization, suppression and denial, I seek to uncover the aspects of the Kurdish movement that transformed it into a powerful force for social and political change. Within this framework, the present study focuses primarily on the reasons behind the articulation of Kurdish demands within the scope of a wider democratic movement for change, how these demands are communicated to the state and the society in general, and what role this process plays in the transformation of both Kurdish identity and political goals, and the established notions of democracy, governance and citizenship within the Kurds' respective polities.

Why I chose the political elite as my target group instead of the non-elite is related directly to my research question and methodology. The main questions my research seeks to answer relate to the transformation of Kurdish nationalism in Turkey, Iran, Iraq and Syria and the diverse ways through which this process shapes Kurdish identity and national demands as well as domestic and regional politics in the Middle East. I draw mainly on a critical analysis of the modernist school of nationalism and the discourse analysis framework that is based on the underlying premise that "our ways of talking do not neutrally reflect our world, identities and social relations but, rather play an active role in creating and changing them.. ${ }^{, 53}$ In the field of politics, the discourse analysis framework becomes particularly relevant given that engaging in politics often involves engaging in discursive practices. In this regard, political discourse can be briefly

\footnotetext{
${ }^{53}$ Phillips, Louise, Jørgensen, Marianna W. (2002). Discourse Analysis as Theory and Method, London: Sage Publications, 1.
} 
defined as the text and talk of politicians and political institutions that are the principal actors of political discourse.

Despite their crucial position in political science as the main actors of political discourse and political practices, politicians and political institutions are not the only participants in the domain of politics. Whether or not they actively engage in discursive practices, the non-elite, the "masses" are also involved in political discourse as the primary recipients of the political communicative events. However, given my research question, which seeks to provide an understanding of a particular discursive articulation of Kurdish political goals - the democratic discourse, the practices of the major political entrepreneurs in the movement (politicians, opposition groups, rights-based organizations, journalists, lawyers, activists, etc.) are given methodological priority.

Rogers Brubaker draws attention to the methodological drawbacks of what he calls "groupism" in the study of the ethnicity, race and nationhood, and in the study of ethnic, racial and national conflict in particular. ${ }^{54} \mathrm{He}$ speaks of the tendency to treat ethnic groups, nations and races - Serbs, Croats, Muslims, Jews, Blacks, Hispanics and Kurds, for example - as if they are internally homogeneous, even unitary collective actors with a common purpose. In order to go beyond groupism, Brubaker suggests, "ethnicity, race and nation should be thought not in terms of substantial groups or entities, but in terms of practical categories, discursive frames, organizational routines, institutional forms, political projects and contingent events." ${ }^{, 55}$ In this respect, he suggests:

\footnotetext{
${ }^{54}$ Brubaker, Rogers (2002). "Ethnicity without Groups," Archives Européenes de Sociologie, 43 (2), 164.

${ }^{55}$ Ibid. 167.
} 
Although participants' rhetoric and common sense accounts treat ethnic groups as the protagonists of ethnic conflict, in fact the chief protagonists of most ethnic conflict are not ethnic groups as such but various kinds of organizations, broadly understood and their empowered and authorized incumbents. These include states, their organizational components, law enforcement agencies, armed forces units, political parties, ethnic associations, social movement organizations, churches, newspapers, radio and television stations and so on. ${ }^{56}$

As it is with every society, Kurds are also diverse people in terms of their political preferences. Therefore, the debate over whether the pro-Kurdish parties and organizations represent all the ethnic Kurds ${ }^{57}$ is not directly relevant to the current study, which seeks to explain primarily the articulation of Kurdish nationalism beyond the narrowly scoped framework of ethnic nationalism. In this respect, rather than the question of "what is Kurdish nationalism," the current study endeavors to answer the question of "how and with what consequences is Kurdish nationalism institutionalized and constituted as a political and cultural form informed by the discourse of democracy." This approach opens up a large space for the consideration of human agency.

Discourse analysts, such as Ernesto Laclau and Chantal Mouffe, submit that all forms of identity are contingent and constructed within political discourse. ${ }^{58}$ They depart from the idea that discourse constructs the social world in meanings that can never be

\footnotetext{
${ }^{56}$ Ibid. 171-172.

${ }^{57}$ For a discussion on the incongruence between the electoral results in Kurdish-populated areas of Turkey and the ethnic identity of the voters see Tezcur, G. M. (2009) "Kurdish Nationalism and Identity in Turkey: A Conceptual Reinterpretation," European Journal of Turkish Studies, 10; for an analysis of the debate on whether Turkey's pro-Kurdish party pursues ethnic nationalism or acts as a "party of Turkey" see Kavak, Şeref (2012). "Kürt Siyasetinin 2000'li Yılları: "Türkiyelileşme" ve Demokratik Toplum Partisi” (Kurdish Ethnopolitics in the 2000s: Turkey-fication and the Democratic Society Party) in Türkiye Siyasetinde Kürtler: Direniş, Hak Arayışl, Katıllm (Kurds in Turkish Politics: Resistance, Struggle for Freedom, Participation) edited by Büşra Ersanlı, Güney Göksu Özdoğan, Nesrin Uçarlar, İstanbul: İletişim Yayınları.

${ }^{58}$ Günes, Cengiz (2012). The Kurdish National Movement in Turkey: From Protest to Resistance, London and New York: Routledge, 4.
} 
permanently fixed. The overall idea of the Laclau and Mouffe's discourse theory is that social phenomena are never finished or complete, which opens up the way for constant social struggles about definitions of society and identity, with resulting social effects. ${ }^{59}$

Likewise, Brubaker and Craig Calhoun, treat nationalism mainly as a form of "discourse" that comes into being as the conscious creation of a body of people. ${ }^{60}$ Instead of adopting a conventional developmental treatment of nations, Brubaker and Calhoun focus more on the temporality of nationalism and the contingent nature of nationness. Emphasizing the active participation of people in creating and making sense of nationalism, they explain the nation as an entity that is created and sustained by active engagement of a relevant body of people into processes of thought and interchange.

Calhoun proposes we treat nationalism first as a discursive formation, which means it should be examined as a way of thinking and comprehending the world. ${ }^{61} \mathrm{He}$ contends the system of nations is basic to our mental picture of the contemporary world and political practice. This picture is reproduced through words and images as well as through maps, systems of communication and other cultural and political practices, which depict the world as compartmentalized into discrete nations with well-defined boundaries. Calhoun sees it as a useless effort to explain nationalism by a single explanatory variable such as state building, industrialization, unequal economic

\footnotetext{
${ }^{59}$ Louise and Jørgensen. 24.

${ }^{60}$ Brubaker, Rogers (1996). Nationalism Reframed: Nationhood and The National Question in The New Europe, Cambridge: Cambridge University Press; Calhoun, Craig (1997). Nationalism, Minneapolis: University of Minnesota Press.

${ }^{61}$ Calhoun, 22.
} 
development or resentment. What is important for him is only the discourse of nationalism. $^{62}$

Brubaker rejects the understanding of nations as enduring collectivities and emphasizes instead the necessity of determining how the nation is constituted in various times and places, often via competing discourses of the same nation. According to Brubaker, explaining the process through which a particular discursive articulation of the nation becomes momentarily, yet powerfully realized in practice should be central to the work of the analysts of nationalism. ${ }^{63}$

Academic discussions on the Kurds are often interested in historical-sociological explanations about the rise and development of Kurdish nationalism. ${ }^{64}$ These studies focus mainly on the development of Kurdish nationalism in the $20^{\text {th }}$ century as an ethnic stateless reaction against the official state nationalisms of Turkey, Iran, Iraq and Syria. Although they discuss in detail the social, economic and political conditions that gave rise to the politicization of Kurdish identity and the struggle between the Kurds and their respective governments, these analyses remained largely reliant on a single explanatory variable - coercive state policies - while accounting for the evolution of Kurdish nationalism. In that sense, how and why these processes were interpreted as "oppression" and "assimilation" by the Kurds themselves and implicated in their conceptions of

\footnotetext{
${ }^{62}$ Ibid.

${ }^{63}$ Brubaker (1996), 15.

${ }^{64}$ See Entessar (1992); McDowall, David (1996). A Modern History of the Kurds, London and New York: I. B. Tauris; Vali, Abbas (2003). Essays on the Origins of Kurdish Nationalism, Costa Mesa, CA: Mazda Publishers; Ahmed, Mohammed, M. A., Gunter, Michael (2007). The Evolution of Kurdish Nationalism, Costa Mesa, CA: Mazda Publishers.
} 
democracy, national identity, citizenship and governance did not attract much scholarly attention.

Instead of taking a developmental stance, the present study elaborates on the dialectical relationship between the competing political discourses raised by the Kurds and their states, and discusses how the democratic discourse of the Kurds becomes institutionalized and challenges the official state discourses on democracy and governance both at the domestic and regional levels. 


\section{CHAPTER II}

\section{THEORETICAL FOUNDATIONS OF KURDISH NATIONALISM}

Considering how the broader goals of democratization, decentralized rule and achievement of cultural rights were incorporated into the Kurdish nationalist agenda over the past two decades, the question of why the discourse of independent statehood continues to be prominent in the academic as well as policy-oriented analyses of the Kurdish question is intriguing. The fact the Kurds are the largest ethnic group in the world living in a geographically compact area with no nation-state of their own has been viewed as problematic in the context of a modern world system defined by sovereign nation-states. Most studies on the modern history of the Kurds examine the struggle between the Kurds and their central governments with a particular focus on the oppression of the Kurds as victims of assimilationist policies, and the resultant failure of the Kurdish desire for an independent state. Nevertheless, the Kurdish nationalist demands no longer fit this narrative given the proactive nature of the Kurdish movement, which has been gradually unfolding since the 1990s, as well as the shifting discourse of Kurdish nationalism towards an emphasis on democratization under the existing state framework of the Middle East. In this respect, it is imperative to revisit those analyses about the Kurdish question that are driven by a particular theoretical stance, which puts the concept of nationalism exclusively in a state-centric framework.

There has been a remarkable increase in the volume of the academic writing on nationalism, particularly since the end of the Cold War because of the proliferation of ethnic conflicts in many parts of the world. Despite the lack of a scholarly agreement on 
how to define the concepts of nation and nationalism, there has been a growing consensus that nationalism as an ideology and movement is a modern phenomenon that emerged and developed as a result of the major socio-economic processes of modernity such as industrialization, capitalism and the rise of the modern state.

Though Elie Kedourie's Nationalism (1960) stimulated some discussion in the beginning of the 1960s, Ernest Gellner's essay on nationalism in Thought and Change (1964) is recognized by many as the mark of the real beginning of the modern study of nationalism. In the 1970s, the sequential work of Anthony D. Smith $(1971,1976,1979)$ not only made a substantial contribution to the conceptual development of nationalism as a social phenomenon, but also laid the groundwork for the core debate within the field: the divide between ethnicists and modernists. By the 1980s, the body of writing on nationalism flourished further through the works of John Alexander Armstrong (1982), Benedict Anderson (1983), Gellner (1983), Anthony D. Smith (1983, 1986) which were followed by the works of Eric Hobsbawm (1990), Walker Connor (1993), and John Breuilly (1994) during the 1990s. This large body of work produced from the 1970s onwards generally investigates when and how nationalism developed and why it has remained so significant.

Modernists and ethnicists differ mainly over the "when" and "how" of nationalism. Although scholars of both camps agree nationalism is a relatively recent phenomenon, dating from the late eighteenth to early nineteenth centuries, significant differences of opinion arise over the issue of whether the roots of nationalism can be traced back to previous eras. Ethnicists challenge the modernist view primarily on the grounds that while nations may be modern, their origins are not, and that the origins of 
nations can be traced back to earlier periods. ${ }^{65}$ In this regard, the arguments of the ethnicists have important implications for understanding the role played by ethnic identity and shared cultural traits in the emergence of ethnic nationalist challenges to state authority. The modernist view, on the other hand, contributes greatly to the understanding of how shared characteristics become politically activated and give way to nationally conscious polities through its focus on the economic and political changes caused by the process of modernity.

The theoretical divide between the modernists and ethnicists is often overstated. What unites both camps is their emphasis on the territoriality of the nation and the link between the rise of national consciousness and the constitution of independent political entities in the form of states in the modern era. Despite their lack of a specific engagement with the relationship between state and nation, ethnicists acknowledge that, under the right stimulus, groups sharing distinctive religious, linguistic, or racial characteristics will arrive at a corresponding group consciousness, a consciousness that typically manifests itself in the nationalist desire for a state belonging to the group in question. ${ }^{66}$ Modernists, however, consider the cultural aspects of nationalism only as a means to accomplish political goals defined primarily in terms of achieving statehood.

\section{Modernists vs. Ethnicists: A False Dichotomy?}

The modernist stance emphasizes the state in addressing the national question. Achievement of statehood is seen as vital for the survival and maintenance of the nation.

\footnotetext{
${ }^{65}$ Day, Graham, Thompson, Andrew (2004). Theorizing Nationalism, New York: Palgrave Macmillan, 910.

${ }^{66}$ Brown, David (1989). "Ethnic Revival: Perspectives on State and Society," Third World Quarterly, 14 (4): 5 .
} 
The modernists' main model, nation building, credits the existence of nations largely to the deliberate, rational agency of elites promoting collective or individual interests. As modernization disrupts traditional ties and means of subsistence, the nation serves to mobilize the commitment and sacrifice necessary for socioeconomic development. As a territorially sovereign political community featuring a culture of mass civic participation, the nation subordinates all other allegiances of its members (gender, family, class, etc.) to national consciousness. It constitutes the sole medium for development and social redistribution and serves as the main actor in the international arena.

Gellner submits that nationalism is a sociologically contingent phenomenon that possesses time- and context-bound roots. ${ }^{67} \mathrm{He}$ argues that nations and nationalism are sociologically necessary in modern, industrial societies where the intimate structures of traditional society erode ${ }^{68}$ Industrialization brings about a basic convergence towards certain essential technical and occupational norms, and thus requires a homogeneous culture with mass literacy, standardized knowledge and context-free communication. Such a culture, according to Gellner, is possible only through a state-sponsored mass, public education system. National identity constitutes the identification with such a culture, and nations are its expression. In a characteristically modernist outlook, Gellner states that nations are not cultures waiting to be awakened, but products of nationalism, a functional movement inherent in and necessary for modernity. In this respect, he views nationalism as a political principle that primarily refers to the congruence between the political and the national unit.

\footnotetext{
${ }^{67}$ Gellner, Ernest (1964). Thought and Change, Chicago: The University of Chicago Press, 150-151.

${ }^{68}$ Ibid. 165.
} 
In the same vein, Eric Hobsbawm explains nationalism as a political project aimed mainly at statehood. He sees nations primarily as the products of nationalism and affirms that nation, as a social entity, belongs exclusively to a particular, historically recent period. ${ }^{69}$ For Hobsbawm, nation becomes the perfect means for a new sociocultural integration of modern societies and for creating the cohesion and stability necessary in such a society. ${ }^{70}$ In this respect, nationalism becomes politically significant principally due to its state-making and economy-forming power. To control rapid social change and the mass influx of enfranchised citizens, state capitalist elites resort to the construction of emotionally and symbolically charged signs of group memberships. These symbolic, ritualistic practices, which Hobsbawm calls "invented traditions," provide the inculcation of values and norms of behavior. Therefore, according to Hobsbawm, it is pointless to discuss nation and nationality except in so far as they relate to a certain kind of modern territorial state, the nation-state. ${ }^{71}$

Anthony Giddens and John Breuilly demonstrate a more distinctive approach to state-oriented nationalism by endorsing the view that nations and nationalism are mainly the properties of the modern states. Giddens defines the nation as "a collectivity existing within a clearly demarcated territory, which is subject to a unitary administration, reflexively monitored both by the internal state apparatus and those of other states."

\footnotetext{
${ }^{69}$ Hobsbawm, Eric (1990). Nations and Nationalism since 1780: Program, Myth, Reality, Cambridge: Cambridge University Press, 9.

${ }^{70}$ Ichijo, Atsuko, Uzelac, Gordana (2005). When is the Nation? Towards an Understanding of Theories of Nationalism, New York: Routledge, 12.

${ }^{71}$ Hobsbawm, 9-10.

${ }^{72}$ Giddens, Anthony (1985). A Contemporary Critique of Historical Materialism. Vol. 2. The Nation State and Violence, Cambridge: Polity Press, 116.
} 
However, rather than nationalism per se, it is the nation-state in its unique administrative, military and territorial properties that commands Giddens' attention. ${ }^{73} \mathrm{He}$ accords nationalism a sociological significance only insofar as it is linked to the state. It is the state's centralization and administrative expansion that distinguishes the nation-state from other polities and nationalism from other group identities.

Breuilly also sees nationalism as a political movement defined mainly by its relationship with the state and/or goal for statehood. For him, nationalism is inconceivable without the state and vice versa, and the central nationalist goal is autonomy (usually meaning establishment of a sovereign state in the national territory) justified in the name of the "nation" ${ }^{74}$ Nationalist arguments, according to Breuilly, are used to justify the quest for state power, and this is why theorists must focus on the movement's political aspect. Breuilly especially opposes the notion that pre-modern ethnic identity necessarily has any bearing on modern nationalism. He criticized ethnicists on the grounds they exaggerate and distort the occasional use of terms concerning nationality in pre-modern states and they insufficiently appreciate that "ethnicity" is material used, indeed, often invented by modern nationalism rather than one of its essential conditions. ${ }^{75}$

The proponents of the ethnicist view do not deny the argument that both nations and nationalism are, by and large, post-eighteenth century phenomena. Nevertheless, they

\footnotetext{
${ }^{73}$ Smith, Anthony (1998). Nationalism and Modernism, New York: Routledge, 72.

${ }^{74}$ Breuilly, John (2001). "The State and Nationalism" in Understanding Nationalism edited by Montserrat Guibernau and John Hutchinson, Cambridge: Polity Press, 32.

${ }^{75}$ Ibid. 34.
} 
object to the modernists' tendency to assume a sharp break between modernity and previous eras, which, according to ethnicists, leads to the neglect of the complex interplay between the modern nations and the collectivities that predated them. Ethnicists argue the modernizing processes such as industrialization, capitalism and the rise of the modern state may convert the ethnic cultures into national cultures, but cannot "invent" them. Although they do not have a particular tendency to conflate the nation with the state, ethnicists do share the modernists' state-centric understanding of nationalism by emphasizing the relationship between the rise of ethno-nationalist consciousness and the establishment of independent political units in the modern era.

Anthony Smith, who is a pioneering figure in the study of nationalism, argues that most nations, including the earliest, were based on ethnic ties and sentiments and on popular ethnic traditions, which have provided the cultural resources for later nationformation. ${ }^{76}$ Smith acknowledges nations are modern forms of community, yet he insists that nations and nationalism draw sustenance from a "living," pre-modern ethnic past with ties to earlier ethnic communities (which Smith terms as ethnie), to their symbols, and to the memories of their values and exploits. ${ }^{77} \mathrm{He}$ contends that although nations and nationalism are modern, a historic ethnic foundation is necessary for their survival and it is the ethnie that provides that foundation.

Smith disputes the link that modernists highlight between the modern industrial era and the rise of nationalism, and argues that modern forces revitalize, in changed form, the social and cultural relations of past eras, and do not engender completely novel forms

\footnotetext{
${ }^{76}$ Smith, 12.

${ }^{77}$ Smith, Anthony (1999). Myths and Memories of the Nation, Oxford: Oxford University Press, 19.
} 
of collective belonging. In this respect, he sees ethnicity - which modernists almost completely ignore - as a key explanatory variable in accounting for the origin of the nation-states. In his definition of nationalism, Smith underlines the rise of modern, statecentered political consciousness as an important element for fostering nationalist sentiments. However, he rejects the notion that ethnicity is a by-product and vehicle for cultural homogeneity, statehood or socioeconomic emancipation. Rather, he attributes causal primacy to ethnicity in the formation of the nation and the nation-state model.

Other prominent ethnicist scholars such as Walker Connor and John Hutchinson also emphasize the inherently ethnic character of nationalism. Connor argues that explaining nationalism simply as a rational quest for collective goods leaves no room for collective values, memories, symbols, and emotions, and such an account is not enough to explain the passion and wide appeal of nationalism. For Connor, what is crucial in the study of nationalism is the subconscious belief in the group's separate origin and evolution, which is an important ingredient of national psychology. ${ }^{78}$ However, despite his emphasis on the ethnic character of nations, Connor eventually refers to certain aspects of modernization, such as the advances in mass communications and transportation, while explaining the process through which ethnic groups reach the level of consciousness as necessary for being a "self-aware" community. He asserts that the growth of ethno-nationalist consciousness gave rise to increasing political mobilization in

\footnotetext{
78 Connor, Walker (1994). Ethnonationalism: The Quest for Understanding, Princeton: Princeton University Press, 197.
} 
many parts of the world in the post-World War II period, and made political independence a viable option for many smaller ethnic groups. ${ }^{79}$

In his criticism of the modernist scholars who confine the use of the term "nationalism" to a purely political movement and its capacity for state-making, Hutchinson makes a distinction between political and cultural nationalism. He defines political nationalism as a civic polity of educated citizens whose objective is to secure a representative state for their community, while the cultural nationalist perspective gives primacy to the distinctive civilization of the nation, which is the product of its unique history, culture, and geographical profile. ${ }^{80}$ Nevertheless, Hutchinson does not deny the importance of political nationalism and points out that its focus on the state and citizenship is regularly complemented by cultural forms of nationalism that seek a moral regeneration of the community and an inner renovation of ethnic base.

The modernist-ethnicist divide within the contemporary debate on nationalism presents more a mutually complementary framework than a dichotomy. The ethnicist view begs the question of why some "objective" cultural groups fail to develop strong group consciousness while others with more tenuously shared characteristics emerge as fairly unified, ethnically conscious polities. ${ }^{81}$ The modernists' emphasis on factors such as capitalism, industrialization, mass communications and elite politics provides an explanation regarding the stimuli through which shared cultural traits become politically

\footnotetext{
${ }^{79}$ Connor, Walker (April 1972). "Nation-Building or Nation-Destroying?" World Politics, 24 (3), 328-331; also see Connor, Walker (January 1993). "The Politics of Ethnonationalism," Journal of International Affairs, 27: 1-21.

${ }^{80}$ Hutchinson, John (1987). The Dynamics of Cultural Nationalism: The Gaelic Revival and the Creation of the Irish State, London: Allen \& Unwin, 12-13.

${ }^{81}$ Geertz, Clifford (1973). The Interpretation of Cultures: Selected Essays, New York: Basic Books.
} 
activated and create a collective sense of belonging that manifests itself in the form of nationalism. In other words, although the pre-modern ethnic ties and sentiments provide the cultural resources for later nation-formation, the saliency of ethnic identification as a political factor is determined by the social, economic and political changes evoked by the process of modernization.

The modernist approach, on the other hand, overlooks the psychological aspects of nation-building process by putting the nationalist sentiments in a purely instrumentalist framework. Although the nation may be socially constructed, it cannot be pulled out of thin air. The standard rational choice accounts assume that ethnic kinship ties are fictional, and can therefore be seen instrumentally in the context of the leaders' strategy to manipulate ethnicity for the sake of personal or collective economic or political gains. The difficulty with this account is that it fails to explain why ethnicity would be the basis for mobilization at all rather than other types of allegiances such as economic interest, class or gender. The modernist stance is not well equipped to answer this question mainly because it overlooks the "value-rational" micro-foundations of ethnic or national mobilization. For ethnicity to be instrumentally used by the leaders, ethnicity must exist as a valued good for some in the first place.

\section{The Limits of an Emerging Theoretical Synthesis}

A view that takes the various components of ethnicity (language, culture, shared origins and religion) as the building blocks from which national identification may be constructed resolves the modernist/ethnicist divide. Although the modernists and ethnicists account for two distinct aspects of nationalism - political and cultural, respectively, for both, the nation-state model represents the institutionalized form of the 
nation. In other words, whether they see the pre-modern ethnic ties as fictitious or real, both views embrace the state as the main guarantor of collective identity and presuppose congruence between political and cultural boundaries. Thus, nationalism is considered primarily as the locus of the claim to popular sovereignty, which presupposes an idealtype of the nation-state, an entity in which all citizens will be members of its uniform community. ${ }^{82}$

For the modernist, while nationalism provides the state with ideological legitimacy, the state guarantees the rights and freedoms of those it considers to be its own members and provides them with protection. This formula works perfectly in cases where the state and the nation align, as in Gellner's terms, where there is congruence between state and culture. If this is not the case, the people who do not have the "right" cultural characteristics choose between assimilating, migrating or becoming irredentist nationalists in order to change their situation. The options of the state toward those who do not fit its local dominant characteristics range from assimilation to expulsion or "ethnic cleansing." ${ }^{83}$ Indeed, the majority of the $20^{\text {th }}$ century's ethnic conflicts validate the premise that the cultural homogenization imposed by the elites is not sufficient for the sustenance of the nation, and that pre-existing cultures, including ethnic cultures, are an important basis for political mobilization in ethnically diverse societies.

\footnotetext{
${ }^{82}$ Vali, Abbas (2003). "Genealogies of the Kurds: Constructions of Nation and National Identity in Kurdish Historical Writing" in Essay on the Origins of Kurdish Nationalism edited by Abbas Vali, Costa Mesa, California: Mazda Publishers, 68.

${ }^{83}$ Gellner, Ernest (1997). "The Turkish Option in Comparative Perspective" in Rethinking Modernity and National Identity in Turkey edited by S. Bozdoğan, R. Kasaba, Seattle and London: University of Washington Press, 240.
} 
For the ethnicist, the causal relationship between state and nation is based upon the primacy of ethnic unity as the necessary condition for the survival of the nation and the viability of the nation-state. As the politico-administrative reach of the governments was extended to the peripheral ethnic homelands in the modern era, these groups developed a desire to preserve their autonomous lifestyles, which hardened the attachments to ethnic identities. In this context, increased cultural awareness combined with uneven diffusion of modernity leads to the emergence of ethnic nationalism as a way to respond to the cultural disorientation and physical disruption of the traditional way of life. As perceived dependence and exploitation gives rise to ethno-nationalism, achieving self-determination, defined as political independence in the form of separate statehood, becomes a major goal for most of the politically mobilized ethnic groups. In this context, alignment of the cultural boundaries of the pre-modern ethnic homelands with the political boundaries of the newly-established nation-states is viewed by the ethnicists as the primary condition that guarantees the sustainability of the nation.

Although the ethnicists gain the upper hand in explaining the emergence of ethnonationalist movements, the state-based solution they offer in addressing the national question eventually creates a variant of modernist view insofar as they see cultural homogeneity as the major requirement of the nation-state. In other words, while criticizing the exclusive and intolerant character of the "national" condition of modernity, the perspective of the ethnicist serves to regenerate the state institution in its same exclusionary form, referring to a unique people identified with unique cultural characteristics. In that sense, both the modernist and ethnicist accounts of nationalism fall 
short of dealing with the issues of cultural diversity and the broader minority questions in multi-ethnic, multi-cultural and religiously diverse societies.

The contemporary debate on nationalism is largely silent on the question of cultural heterogeneity. Rather, the notion of nation built on a common culture is taken for granted, and the correspondence between the political and ethnic boundaries of the state is seen as essential for the legitimacy of the nationalist cause and the national state. Where cultural diversity poses a threat to the socio-political cohesiveness, political stability and territorial integrity of the state, proponents of both sides of the debate leave us with nothing but the options of either assimilation or the establishment of a new state that would provide the necessary protection for those who secede. Within this framework, the state is presented by both modernists and ethnicists as the main instrument of security for the members of the nation. This approach leaves no room for debating an alternative project that could entail the development of a profound unity respecting ethnic and cultural diversity under conditions where the state becomes a source of insecurity for certain segments of the population.

If the nation-state secures the rights of its citizens, then surely it is a necessity; but if the nation-state relies on nationalism and invariably produces massive numbers of stateless people, it certainly needs to be opposed. ${ }^{84}$ The idea of human rights born during the Enlightenment was intended to be universal. Nonetheless, the evolution of the state into the "nation-state" and the corresponding tendency to conflate nation with state gave an exclusively national definition to the scope of the community whose rights were to be

\footnotetext{
${ }^{84}$ Arendt, Hannah, Kohn, Jerome (ed.), Felman, Ron H. (ed.) (2007). The Jewish Writings, New York: Schocken Books.
} 
enforced and protected. Such a stance fails to address core questions about how nations and states may engage in an ongoing social and political exchange in the configuration of both domestic and international life. Clarifying these tensions is an important precondition for developing politically more satisfying models.

If the nation-state falls short of ensuring the rights of everyone under its jurisdiction and is to be opposed, the question then arises as to what will serve as its alternative. If the realization of fundamental human rights presupposes some particular state agency to guarantee rights and freedoms for those it considers to be properly its own members, a problem arises for those who are culturally different and lacking their own nation-state, notably the minorities. Feeling insecure, the more minority populations are excluded from rights, the more they tend to look for a reintegration into a national community of their own. ${ }^{85}$ Hannah Arendt argues the only way to make the state a safe repository of human rights for all its citizens is by taking the nation out of the nationstate. ${ }^{86}$ The way to do this, according to Arendt, is by meshing the state to a web of federal relations, both below and beyond the state, thereby moving away from the state as a site of sovereignty. Insofar as nationalism is bound to the claim of national sovereignty, any reconfiguration of the state depends upon a liberation from the nationalist legacy. ${ }^{87}$

\footnotetext{
${ }^{85}$ Beiner, Ronald (2003). Liberalism, Nationalism, Citizenship: Essays on the Problem of Political Community, Vancouver: UBC Press, 139.

${ }^{86}$ Ibid. 140.

${ }^{87}$ Ibid.
} 
In her examination of the "Jewish question," 88 Arendt puts an emphasis on the opportunity for Jews to become a nation and elaborates on the structure of the state that might embody their nationhood and its principal condition. ${ }^{89}$ Within the framework of her well-known and much debated notion of "the right to have rights," which she sees as the principal human right, she focuses on the right of a people to become a nation by founding a state whose institutions announce and guard the civil rights of its citizens. ${ }^{90}$ However, while the foundation of a state, "a new kind of state," was what Arendt saw as the goal of the Jewish people, she rejected the idea that the structure of this new state in Palestine should be that of a European nation-state. The binational Arab-Jewish state she envisions is based on a council system of governing. "Local self-government and mixed Jewish-Arab municipal and rural councils, on a small scale and as numerous as possible, are the only realistic political measures that could eventually lead to political emancipation of Palestine, ${ }^{, 91}$ as Arendt puts it.

There is no doubt the Kurdish efforts at self-determination principally derive from the failure of the states of Turkey, Iran, Iraq and Syria to safeguard the rights of their Kurdish citizens. According to the modernist and ethnicist accounts of nationalism, this situation automatically lends itself to the solution of establishing a Kurdish nation-state which would be the only entity that could provide the necessary protection. Nevertheless,

\footnotetext{
${ }^{88}$ Arendt uses the term "Jewish question" mainly as referring to the problematic situation of an identifiable people living in a land that is not their land but that of another people.

${ }^{89}$ Kohn, Jerome (2007). "Preface: A Jewish Life: 1906-1975" in The Jewish Writings edited by Jerome Kohn and Ron H. Feldman, New York: Schocken Books, xxiv-xxv.

${ }^{90}$ Ibid. xxv.

${ }^{91}$ Arendt, 401.
} 
it is striking that the evolutionary trajectory of Kurdish political discourse poses a significant challenge to this assumption. In other words, the mainstream statist thought on nationalism is not able to explain the Kurds' political position in Turkey, Iran, Iraq and Syria.

Building a "new state" had certainly become the main goal of the Kurdish nationalist movement in the late twentieth century. However, the manner in which this goal unfolds since the early 1990s suggests that the national liberation envisioned by the Kurdish political elite has less to do with establishing a separate Kurdish nation-state than becoming an effective oppositional force in pushing for political change within the borders of Turkey, Iran, Iraq and Syria. Although the dynamics of the relationship between the Kurds and their respective central governments vary from one country to another, the Kurdish movements' move toward democratization has made them important political players in each of the four states as they try to address such important issues as minority rights, democracy and federalism. In that sense, contemporary Kurdish nationalism warrants an objective scholarly investigation, not only as it impacts the crucial political developments within the states in which the Kurds live, but also as it shapes the Kurds' interactions with each other across borders and with the regional and global players involved in restructuring state-society relations in the Middle East.

\section{Structural Approaches to the Study of Kurdish Nationalism}

Structural explanations are the backbone of the modernist thought that traces the origins, rise, and course of nations and nationalism to the consequences of uneven capitalism, industrialism and rise of the modern state. Although they attribute a relatively greater role to human agency in explaining nationalism by referring to shared ideas, 
sentiments, meanings and definitions among the adherents of a given cultural or ethnic group, ethnicists also rely heavily on the process of modernization and the underlying structural changes in explaining the development of group self-awareness and politicization of ethnic identity. While the ethnicist approach defines nationalism on the basis of a uniform ethnic origin ever-present in history, the modernist approach deduces it from a mythical origin constructed by modernity. In both cases, the nationalist discourse has no autonomy; it is an effect or expression of either real or assumed national origin constituted by the objective structures of industrial capitalism and the culture of modernity.

One of the main issues in treating the Kurdish question as a problem of democracy rather than a problem of statelessness strictly defined in ethnic terms is that one must maintain a distance from the structural analysis of the relationship between the Kurds and the state. Adopting such an approach is crucial in order to understand Kurdish nationalism from the perspective of the "Kurds." It is the Kurdish political actors who define the Kurdish question as a problem of human rights, democracy, and political participation in the first place. Thus, any analysis that considers the Kurdish question in the context of the democratization process in Turkey, Iran, Iraq or Syria needs to open up a large space for the role of human agency rather than depending solely on the structural factors as the main determinants of Kurdish political action.

The hegemonic representation of the Kurdish question as a case of "separatism" and "terrorism" in state discourses puts constraints on the development of academic debate and research on the Kurds throughout much of the $20^{\text {th }}$ century. As the host governments frequently prohibited or placed restrictions on the publication and 
dissemination of information on the Kurds, the "official" representation of the Kurds in state and popular media discourses remained largely unchallenged until the 1960s. From the 1960 s to the 1980 s, only a limited number of academic works were published in the field of Kurdish Studies and they were focused primarily on the Kurdish cause in Iran (Eagleton 1963; Ghassemlou 1965) and Iraq (Adamson 1964; Jawad 1981; Ghareeb 1981). From the 1960s onwards, Turkey's official state discourse on the Kurdish question started to face a challenge from the Kurdish activists who led to the emergence of the Kurdish movement as an influential political oppositional force in Turkey in the 1970s. Accordingly, from the 1980s onwards, the increase in Kurdish political activism witnessed a corresponding increase in the number of books and articles on Kurdish identity and nationalism in Turkey. The Kurdish factor in Syria, on the other hand, remained marginal in academic research dedicated to either Syria or the Kurdish question until the Qamishli revolt of 2004, which is accepted as a major milestone regarding the growth of Kurdish nationalism in Syria.

By the 1990s, the increased salience of Kurdish nationalism as a political factor, particularly in Turkish and Iraqi politics, resulted in a remarkable upsurge of academic work on the Kurdish question. The first comparativist and more theoretical work on the Kurds were published in this period (Entessar 1992; Chaliand 1993; Gunter 1993, 1997; Olson 1996, McDowall 1996; Ciment 1996). From the late 1990s and throughout the 2000s, Kurdish Studies was increasingly integrated into country studies and comparative work focusing on all four parts of Kurdistan. These studies address a diverse range of issues and focus on different periods and aspects of Kurdish society and politics. An overwhelming number of these studies focus on the historical origins and development of 
Kurdish nationalism in the Middle East with particular attention paid to the conflict analyses of Kurdish political actors and state authorities as well as the accounts of the political history of Kurdish nationalism in Turkey, Iran, Iraq and Syria. ${ }^{92}$

The political history literature predominantly focuses on the evolution of Kurdish national movement and the politicization of Kurdish identity after the establishment of modern nation-states in the Middle East in the early twentieth century. The political history accounts by Van Bruinessen (2000), White (2000), Natali (2005), Tahiri (2006), Ahmed and Gunter (2007), Tejel (2009) and Aziz (2011) generally trace the evolutionary trajectory of Kurdish nationalism with a particular focus on the nation-state building processes in Turkey, Iran, Iraq and Syria as the major determinant of the rise of Kurdish ethno-nationalism in the $20^{\text {th }}$ century. These studies not only highlight the significance of the modernization process - increased urbanization, educational opportunities and communications - in giving rise to the politicization of Kurdish identity in the newlyestablished nation-states of the Middle East, but also analyze the internal social and economic characteristics of the Kurdish society as a causal factor in explaining the failure of the Kurds to establish a nation-state of their own.

Similarly, the conflict analysis literature as exemplified by the works of Gunter (1990), Kirişci and Winrow (1997), Barkey and Fuller (1998), Özcan (2006), Romano (2006), Vali (2011) and Eccarius-Kelly (2011), examine the conflict between the Kurds and their respective central governments in a historical context. They refer to particular theoretical frameworks such as social movements and constructivist approaches in

\footnotetext{
${ }^{92}$ Cengiz, 8 .
} 
accounting for the origins and evolution of the encounters between the sovereign powers, and the Kurdish communities and their political representatives.

Recently, studies that have a narrower focus on a particular aspect of the contemporary Kurdish national movement have also been published such as the works by O'Leary, McGarry and Salih (2005), Yıldız (2005), MacDonald and O'Leary (2007), Lawrence (2008), Visser and Stansfield (2008), Gunter (2008) and Natali (2010). These studies deal predominantly with the social and political changes that took place within the Kurdish national movement since the early 1990s with a particular focus on the debates on democracy and federalism in Iraq after the 2003 American intervention and the increasing significance of the discourse on human rights regarding the Kurdish question in Turkey within the context of Turkey's EU accession process.

Following the first Gulf War, the literature on the Kurds and Kurdish nationalism was enriched greatly through the political history and conflict analyses accounts of Kurdish political activism. However, works produced in the field of Kurdish Studies continue to focus on structural factors - the market, the economy, industrialization, capitalism, education, communication, transportation - in explaining the rise and development of the Kurdish national movement. Informed largely by the mainstream structural-statist theoretical frameworks on nationalism, contemporary Kurdish scholarship often highlights the causal relationship between the processes of statebuilding and modernization in the Kurds' host countries and the social and economic changes that took place in the Kurdish society. These studies usually trace the roots of Kurdish nationalism back to the state formation period in the Middle East after World War I, and examine the Kurdish national movement as a phenomenon primarily shaped 
by the state-building policies in Turkey, Iran, Iraq and Syria. Accordingly, the evolution of Kurdish nationalism is principally explained as a function of these diverse political environments in which the Kurds act, and whether or not Kurdish nationalist aspirations become publicly salient is viewed largely in the context of the positive or negative incentives offered by the central governments.

Although these analyses have extensive explanatory power in terms of understanding the variations in the manifestation of Kurdish nationalism across space and time, they fail to capture the changes in the Kurdish national movement during the contemporary era because of the limitations imposed by framing the problem from the perspective of the political structures of the states in which the Kurds live. Lately, the works of Marlies Casier and Joost Jongerden (2010), Cengiz Güneş (2011) and Büşra Ersanl1, Günay Göksu Özdoğan and Nesrin Uçarlar (2012) made important contributions to the literature by clarifying how the demands of the Kurds were constituted in the discourses of the Kurdish political elite, and then communicated to the state authorities and society at large in the context of the pro-Kurdish actors' attempts to transform their respective polities. These studies have opened a greater space for Kurdish agency within the policy-making processes.

Others such as Nicole Watts (2010), despite giving an account of the Kurdish democratic and legal forms of engagement as a political oppositional force in Turkey, analyzes the pro-Kurdish parties largely from the perspective of the official Turkish discourse. Her study "does not include a discussion of the conception of democracy being proposed by the pro-Kurdish movement, how it addresses questions of pluralism - both within and outside the Kurdish community - and to what extent this discourse of 
democracy has challenged the notions of democracy and citizenship in Turkey." ${ }^{93}$ Hence, an in-depth study of the fluid and reciprocal relationship between the Kurds and their respective central governments and the role that the Kurdish political actors play in reshaping the legal and institutional structure and political alignments within their respective polities remains a major gap scholars have not yet addressed.

The structural accounts of Kurdish nationalism often take the "political opportunity structures" as their point of departure. Political opportunity structures are explained on the basis of the premise that emphasis should be given to the interaction between the movement and institutionalized politics and the importance of the broader political system in structuring opportunities for collective action. ${ }^{94}$ A political opportunities perspective seeks to show how changes in some aspect of a political system create new opportunities or constraints for activist efforts in order to explain the emergence of a particular movement or "cycle of protest."

Laying the foundation in this tradition, Charles Tilly, in his classic From Mobilization to Revolution (1978), explains what he calls as the "polity model," which relates contenders to a government and to other contenders via coalitions and struggles for power. ${ }^{96}$ The polity model deals with the surrounding world that is likely to affect the contender's well-being, that is, by considering incentives or opportunities to act. In other

\footnotetext{
${ }^{93}$ Cengiz, 15-16.

${ }^{94}$ McAdam, D., McCarthy, J. D., Zald, M. N. (1996). Comparative Perspectives on Social Movements: Political Opportunities, Mobilizing Structures, and Cultural Framings, Cambridge: Cambridge University Press, 2-3.

${ }^{95}$ Ibid. 17.

${ }^{96}$ Tilly, Charles (1978). From Mobilization to Revolution, Reading, PA: Addison-Wesley, 70.
} 
words, the strengths and weaknesses of the external actors comprise the contender's opportunities to act on its interests. ${ }^{97}$

Similarly, David Meyer suggests, "the primary point of the political opportunity approach was that activists do not choose goals, strategies, and tactics in a vacuum. Rather the political context, conceptualized fairly broadly, sets the grievances around which activists mobilize, advantaging some claims and disadvantaging others." ${ }^{98} \mathrm{He}$ asserts 'the wisdom, creativity, and outcomes of activists' choices - their 'agency' - can only be understood and evaluated by looking at the political context and the rules of the games in which those choices are made - that is, "structure." 99

Political opportunity accounts of the Kurdish question by scholars such as Paul White (2000), Hakan Yavuz (2001), Denise Natali (2005), Nader Entessar (2007) and Nicole Watts (2007) generally focus on state policies as the determining factor in the development of the Kurdish national movement, particularly the politicization of Kurdish identity. In explaining the evolution of Kurdish nationalism, these accounts explain Kurdish political action by referring to the opportunities and constraints facing the Kurds. Within this framework, the political opportunity perspective enables scholars of Kurdish Studies to address two questions: how the movement emerges on the one hand, and its ongoing development, on the other. Nonetheless, while tracing the evolutionary trajectory of the Kurdish movement, these accounts do not explore the encounters between the Kurds and the state as a reciprocal process. During their confrontations with the political

\footnotetext{
${ }^{97}$ Ibid. $70-137$.

${ }^{98}$ Meyer, David S. (2004). "Protest and Political Opportunities," Annual Review of Sociology, 30: 127-128. ${ }^{99}$ Ibid.
} 
structure, the Kurds, as a challenging group, also affect legislative or other forms of political change that serves to restructure the legal and institutional basis of the political system.

Other studies such as Michael Gunter (2008) and Kerim Yıldız and Mark Muller (2008) focus on external opportunity structures, namely, the U.S. intervention in Iraq in 2003, and Turkey's EU accession process, as factors that explain the increasing salience of Kurdish nationalism in twenty-first century. However, although they contribute greatly to the literature in terms of addressing the role of external factors in providing new forms of support for Kurdish nationalist projects, these accounts do not demonstrate how the externally-based opportunity structures are reinterpreted by the Kurdish actors and expressed within their political agendas attempting to make new opportunities in the domestic realm.

Within the literature, there are also studies that analyze the mobilization strategies and the cultural and social-psychological tools employed by the Kurdish political groups in order to strengthen Kurdish collective action and organizational capacity. David Romano (2006), besides providing a political opportunity account, examines various vehicles of mobilization as well as social psychological and cultural factors that serve as crucial inducements to Kurdish collective action in Turkey, Iran and Iraq, and does this from a comparative perspective. Ali Kemal Özcan (2006) specifically analyzes the discourse of the PKK from the 1970s to early 2000s and focuses on the views and ideas of the organization as well as its political objectives and corresponding strategies for action. Martin Van Bruinessen (2003) draws attention to the development of Kurmanci as a modern literary language and its role in the emergence of Kurdish national awareness 
during the evolution of the Kurdish movement. Farideh Koohi-Kamali (2007) studies the transition of Kurdish society in Iran from a traditional tribal community to a society with market-based economic and social relationships, and discusses the impact of economic developments in Kurdish society on the expression of political demands for independence. Nicole Watts (2006) provides a discussion of the Kurdish participation in electoral politics in Turkey as a form of social movement activism for surviving, consolidating and advancing the Kurdish political agenda.

Although these accounts provide important reflections on the cognitive, ideational and strategic dimensions of the Kurdish collective action and the roles they play in the construction of Kurdish nationalist discourse, the scholarship does not offer a comprehensive analysis of how this repertoire of collective action is used by the proKurdish contentious actors to create new opportunities and widen the cycle of contention in order to challenge and transform existing political systems. In other words, although they open a greater space for the role of agency in contentious politics, these studies do not provide a discussion of the contentious actors' dynamic relationship to the opportunity structures and their potential to transform their given polity.

While it is true the institutionalized political systems and changes in the patterns of political opportunities and constraints play a significant role in shaping the prospects for collective action and the forms movements take, they are not an inevitable prerequisite to action. Structural explanations suffer from a high level of determinacy by assuming that the structural changes in government and society inevitably produce changes in social movements. Such a stance does not leave room for unintended movement-initiated change in the structure of political opportunities. 
William Gamson and David Meyer remind us that "opportunities open the way for political action, but movements also make opportunities." ${ }^{100}$ Nonetheless, the observation of Gramson and Meyer is not widely reflected either in the field of Kurdish studies or in the broader literature on social movements. As Doug McAdam underscores:

While lavishing attention on the impact of political opportunities on the timing, form, and consequences of social movements, movement scholars have spent comparatively little time and energy systematically studying the role that movements have played in reshaping the institutional structure and political alignments of a given polity. ${ }^{101}$

Given that the majority of the Kurdish studies scholars emphasize the increasing importance of the Kurdish movement as a powerful force for change in society, their collective failure to undertake any systematic and comprehensive accounting of the effect of the Kurdish movement on the various dimensions of political opportunities is puzzling. In this respect, the literature on the Kurds falls short of capturing the dynamic, reciprocal, and crucially important relationship of the Kurdish actors to structures of political opportunity. McAdam states:

Those structures simultaneously constrain and facilitate collective action by a wide range of challenging groups. Those who temporarily benefit from the structure are apt to act aggressively to take full advantage of the opportunities accorded them. In doing so, they are likely to effect legislative or other forms of change that serves to restructure - in both intended and unintended ways - the legal and institutional or the relational basis of the political system or both. Thus transformed, the structure of political opportunities once more acts back to confront the population of challenging groups with new constraint and possibilities for action. ${ }^{102}$

\footnotetext{
${ }^{100}$ Gamson, W. A., Meyer, D. S. (1996). "Framing Political Opportunity” in Comparative Perspectives on Social Movements: Political Opportunities, Mobilizing Structures, and Cultural Framings edited by Doug McAdam, John D. McCarthy and Mayer N. Zald, Cambridge, Cambridge University Press.

101 McAdam, Doug (1996). "Conceptual Origins, Problems, Future Directions" in Comparative Perspectives on Social Movements: Political Opportunities, Mobilizing Structures, and Cultural Framings edited by Doug McAdam, J. D. McCarthy and M. N. Zald, Cambridge, Cambridge University Press. 36-37.

${ }^{102}$ Ibid.
} 
Since the early 1990s, the Kurdish national movement can be said to acquire a dual character: an ethno-cultural struggle for the recognition of Kurdish identity and demands, and a democratization movement for the prohibition of human rights violations and the achievement of democratic reforms. In other words, Kurdish nationalism is no longer defined solely by ethnic assertiveness but also by wider claims for expanded rights and democratic governance for all the nationalities coexisting with the Kurds. Explaining this discursive transformation merely as a change in political tactics and strategy or a derivative of the structures of political opportunity leaves no room for considering the Kurdish question outside the framework of the official state discourses.

The process by which the Kurdish question became intertwined with the question of democratization transformed the relationship between the Kurds and their respective central governments. The Kurdish parties and activists seek to challenge the political and ideological authority of the state not only on the basis of identity politics, but also by raising claims for a competing vision of culture, governance and political representation to that espoused by the central governments of Turkey, Iran, Iraq and Syria.

Restricting the study of the Kurdish question to a narrowly defined framework of reactive nationalism unfavorably assigns a passive role to the Kurdish movement in its encounters with the state. In other words, the Kurds' capacity to engage in politics is simply confined to the "right to react" which subordinates the movement to one which derives solely from the actions and decisions of those in power. Such an approach not only precludes the consideration of the Kurdish movement as an autonomous actor, but invariably reproduces the narratives of victimhood, which allows governments to claim 
full agency in the processes at work in the definition, transformation and the eventual solution of the Kurdish problem. 


\section{CHAPTER III \\ KURDS IN IRAQ}

Iraq is facing a serious crisis. We have tried our utmost to prevent Iraq from descending into a sectarian conflict and we have consistently avoided taking sides in this conflict. The Kurds have played a pivotal role in bringing about the new Iraq, particularly two years ago when our initiative resulted in the formation of the current government. Had it not been for our role, one can only guess what an unknown fate would have beset Iraq. It is very unfortunate that a small number of people in Baghdad have imposed themselves and monopolized power. ${ }^{103}$

After the 2003 American invasion of Iraq and the toppling of Saddam Hussein's regime, the southern and central governorates of Iraq became mired in civil war and economic stagnation, while the Kurdish north experienced relative stability and certain levels of development. ${ }^{104}$ In the context of the new power-sharing system established in Iraq following the approval of 2005 constitution, this asymmetrical growth largely influenced center-periphery relations by strengthening the Kurdistan region's political power in relation to the state and increasing its leverage on the central government to accommodate Kurdish demands. ${ }^{105}$ This situation inevitably revitalized the long term Kurdish-Arab animosity that lies at the intersection of fundamental questions about the future of Iraq. These questions include the stability of the new regime, the process of

\footnotetext{
103 "On eve of Kurdish New Year, President Barzani delivers key address," March 21, 2012. http://www.krg.org/a/d.aspx?l=12\&s=02010100\&r=223\&a=43432.\&s=010000 (Accessed November 11, 2013).

${ }^{104}$ Natali, Denise (2010). The Kurdish Quasi-State: Development and Dependency in Post-Gulf War Iraq, New York: Syracuse University Press, 2010, p. xix.

${ }^{105}$ Ibid. xx.
} 
democratic transition, and whether Iraq will become a truly federal state with an inclusive vision towards its ethno-sectarian diversity.

Barzani's statement on the Kurdish New Year in 2012 highlights the role of the Kurdish movement not only in establishing a new political order in Iraq, but also in ensuring the future stability of the regime in the context of the challenges facing the newly-established power-sharing system. The relationship of the Kurds to the process of democratization in Iraq is a complex one that raises the question of whether the Kurdistan region is a stabilizing or a disintegrating force. Why has the Kurdish movement in Iraq become so central to the questions of whether Iraq can be democratic or whether federalism can stabilize Iraq, particularly in the post-Saddam era? In the same vein, why has the Kurdish movement in Iraq gained greater prominence within its respective political environment compared to its counterparts in Turkey, Iran and Syria?

One answer lies in the sheer demographic weight and territorial concentration of Kurds within Iraq. ${ }^{106}$ Kurds in all parts of Kurdistan are, by and large, territorially concentrated with the exception of Syrian Kurds who are geographically dispersed along the northern Syrian line. The number of Kurds living in Iraq is less than those living in Turkey and Iran. However, as far as the ethnic demography and comparative rates of voter turnout are concerned, the Kurds have a more significant presence in Iraq, particularly by comparison to their presence in Iran and Syria.

The second explanation for the relative strength of Iraqi Kurdistan is the sustained continuity of the Kurds' armed struggle against successive regimes in Iraq since the

\footnotetext{
${ }^{106}$ O"Leary, Brendan, Salih, Khaled (2005). "The Denial, Resurrection, and Affirmation of Kurdistan" in The Future of Kurdistan in Iraq edited by Brendan O'Leary, John McGarry, Khaled Salih, Philadelphia: University of Pennsylvania Press, 15.
} 
British mandate in Iraq. Organized Kurdish armed struggle against the state started in Turkey only in the 1980s while armed struggle was never a mode of opposition for the Syrian Kurds until the uprising of 2011. Armed struggle in Iranian Kurdistan, on the other hand, proved to be effective in terms of placing the rights of ethnic and religious minorities on to Iran's political agenda, but it was never sufficient to force the government into a political solution.

The crucial factor that affected the success or failure of Kurdish armed struggle in each country is the relative military and bureaucratic capacity of the state. Until the rise of the Baathists in 1968, Iraq was a fairly weak state whose military and bureaucratic capacities were far less than those of republican Turkey or monarchical Iran. Whereas, in Syria, armed struggle as a viable strategy of resistance was generally avoided due to the limited size and organizational capacity of the Kurds. Even during the Baathist regime, the Kurds in Iraq won concessions on language rights, constitutional recognition of their identity, and promises of decentralization mainly as a result of the long struggle waged by the Kurdish armed forces in the country's north. The implementation usually remained poor, but the idea of an "Iraqi Kurdistan" with distinct political and administrative capacity was increasingly solidified.

The third reason Kurdish nationalism endured in Iraq lies with the peculiarities of the British mandate in the early twentieth century. The British policy towards the Kurds throughout the mandatory period was generally marked by the British dilemma of how to reconcile its assertions for democracy in Iraq with its preference for a strong centralizing authority necessary to maintain internal stability and ensure the preservation of Britain's political interests. In this context, the Kurdish uprisings of the 1920s and 1930s were 
perceived by the British largely as disintegrative movements that should be suppressed in order to ensure that the economically important Kurdish areas, particularly the oil-rich Mosul, was attached to the emerging Iraqi state.

On the other hand, the British emphasis on representation and constitutionalism as well as Britain's commitments to both the League of Nations and to the Kurds to grant official autonomy to Kurdistan constrained Britain's ability to encourage a strong government in Iraq. Through the mid-1940s, successive Kurdish revolts were constant reminders of the Iraqi government's failure to maintain order and fulfill its obligations to its Kurdish citizens. The British, therefore, encouraged the official use of Kurdish language, education in Kurdish and appointment of Kurdish officials in the Kurdish areas. Although these policies were never more than half-heartedly carried out and did not ensure the bureaucratic entrenchment of these cultural rights, they assisted in the preservation of the constitutive elements of Kurdish culture and nationalism in Iraq. It is fair to say that under the mandate and indeed until the high tide of Baathist ascendancy (1975-1990), in contrast to the much more repressive situation in Iran or Turkey, the Kurds' separate identity was generally recognized to a greater or lesser extent, or at least not denied, by all Iraqi governments. ${ }^{107}$

The fourth answer to the question of why Iraqi Kurdistan became so fundamental to the future of Iraq and proved more effective in pressing its agenda for greater rights and autonomy than its counterparts in Turkey, Iran and Syria is the sustained organizational capacity of the Kurdish nationalist groups in the country. This situation

\footnotetext{
${ }^{107}$ Farouk-Sluglett Marion, Sluglett, Peter (2001). Iraq Since 1958: From Revolution to Dictatorship, London: I. B. Tauris, 26.
} 
has much to do with the internal instability of the Iraqi state itself as well as the military capacity of the Kurdish movement. Until the establishment of the Baathist regime in 1968, Iraq was suffering severely from successive coups and intra-Arab conflicts. The Kurds, in the meantime, continued to fight for the recognition of their language and administrative control of Kurdistan. Both of these factors hindered full state penetration of Kurdistan and gave the Kurdish leaders opportunities to advance their cultural, administrative and territorial demands. The Kurds never fully controlled Kurdistan until 1991, but they consistently consolidated the governance and control of portions of northern Iraq and maintained minimal state functions.

Finally, regarding intra-Kurdish politics, the power configuration of Iraqi Kurdistan remained predominantly tribal after the establishment of Kurdish nationalism in Iraq in the 1930s and 1940s. However, the tribal leaders' pragmatic partnership with the intellectual and urbanized Kurdish nationalists played a crucial role in the emergence of a functioning Kurdistan in Iraq. While the tribal/modernist divide has been a major source of disunity, so much so it led to crippling episodes of infighting, that disunity has enabled the Iraqi Kurds to better organize in order to conduct armed and political struggle. In sum, although the current status of the Iraqi Kurds has much to do with outside intervention in Iraq, the emergence of Kurdistan as a de facto autonomous entity after Saddam Hussein's defeat in the Kuwait war of 1991 was not an accident. Likewise, the fundamental role of the Kurds within the debate on democracy and federalism in Iraq in the post-Saddam era is not a coincidence. Both developments have their roots in the past developments of the state of Iraq and the evolution of its relationship to Iraq's Kurds. 


\section{The Road to Autonomy: The Legacy of the Armed Struggle}

Until the Kurds gained de facto autonomous status in 1991, Kurdish nationalism in Iraq was for the most part a "reactive" nationalism. After the establishment of the modern state of Iraq, the persistent focus of successive regimes on a unified sense of Iraqi nationalism built around a distinctly Arab narrative led to the establishment of a contentious relationship between the state and the Kurds, who form the second largest ethnic group in the country after the Arabs. The warfare between the Kurds and the governments of Baghdad from 1960 to 1980 created a strong motivation to react in unity against oppression and significantly contributed to the consolidation of Kurdish nationalism in Iraq. More than any other single event in the past half century of Kurdish history in the country, the Anfal campaign of 1988, during which the Kurds were subjected to outright massacre at the hands of the Baath regime, further reinforced the common notion of suffering and provoked a galvanizing nationalism among the Kurds. ${ }^{108}$ After the Kurds gained full control over territory following Saddam Hussein's withdrawal from north in 1991, this element of reactive nationalism steadily gave way to the emergence of the Kurdish movement as one that not only built up a political system in the north for a flourishing region, but also shaped important debates on the future of democracy in Iraq.

The British policy of Sunni "Arabizing" the government in Iraq during the mandatory period was contested right from the beginning by both the Kurds and Shia Arabs. The fact Arab nationalism was established as the primary pillar of the state's

\footnotetext{
${ }^{108}$ Olson, Robert (2005). The Goat and the Butcher: nationalism and State Formation in Kurdistan-Iraq since the Iraqi War, Costa Mesa, CA: Mazda Publishers, 233.
} 
ideological legitimacy meant the distinction between Kurds and Arabs emerged as more intractable than the sectarian divide between the Sunnis and Shia. While the sectarian question in Iraq was mainly a problem of underrepresentation of the Shia within the organs of the state, the ethnic question created a more significant problem due to the competing claims of the Kurds to a nation-state of their own. The Shia Arabs were encouraged to subscribe to the notion of being "Iraqis" through the establishment of a monarchy that was Arab in composition and orientation. The same cannot be said for the Kurds whose grievance was the creation of the state of Iraq itself, which undermined Kurdish attempts to secure autonomy or independence after the collapse of the Ottoman Empire. In this respect, the main distinction between the Shia and Kurdish uprisings in Iraq throughout the twentieth century is that while the aspirations of Shia Arabs were mostly directed toward changing the power configuration within the state, the Kurds had broader demands for a reorganization of the state of Iraq itself.

Throughout the early 1920s, there were constant armed uprisings in northern Iraq. These revolts were, by and large, an expression of traditional Kurdish hostility to imposition of any form of outside authority and a result of the Kurdish tribal chieftains' desire to exploit the disintegration of former power centers to assert their own autonomy in the wake of the collapse of the Ottoman Empire. ${ }^{109}$ These early Kurdish revolts in Iraq were quickly suppressed by the British. In the new post-World War I international order stamped by the principle of self-determination, the uprisings made a strong case for

\footnotetext{
109 Farouk-Sluglett, Sluglett, 25; Tripp, Charles (2007). A History of Iraq, New York: Cambridge University Press, 34.
} 
Kurdish nationalism and posed significant challenges to the configuration of the Iraqi state envisaged by the British authorities.

The 1930s marked the awakening of a national consciousness among the first generation of secular educated and urban Kurds in Iraq who began to develop ideas of how best to secure specifically Kurdish identity and interests within the framework of the Iraqi state ${ }^{110}$ The new urban and intellectual nationalists challenged the dominance of the traditional notables of Kurdistan, yet were aware of the power of the tribal leaders in Kurdish society. When the British and the Hashemite attempted to penetrate Kurdistan with modern direct rule by replacing tribal governance with more bureaucratic yet Arabized administration, some of the tribal notables, determined to defend their privileges, made common cause with the new urbanized and professionalized Kurds who had different grievances and agendas. ${ }^{11}$ This model led to the emergence of the Kurdistan Democratic Party (KDP), under the leadership of a traditional notable, Mulla Mustafa Barzani, and a group of urban intellectuals, notably Ibrahim Ahmed and Jalal Talabani.

Throughout the monarchical rule and into the first years of the republican period, the ethno-sectarian societal structure and the idea of democracy were bound to clash in Iraq. The problem was that building the strong central government necessary to maintain unity in a socially-fractured society conflicted with the goal of creating the representative institutions vital for legitimatizing the order in the eyes of the existing communities, but

\footnotetext{
${ }^{110}$ Tripp, 62.

${ }^{111}$ O’Leary, Khaled, 21.
} 
that would, by definition, constrain governmental action. ${ }^{112}$ The Hashemite monarchical government succeeded in building a strong central government, but largely failed in achieving legitimacy because of the reluctance of the governing elite to cede power in a truly meaningful way by assuring the diverse communities their identities and interests were fully respected. Consequently, a general belief took hold that coercion was necessary to achieve the discipline and unity required to manage Iraq's ethnic and sectarian diversity.

Iraq underwent several periods marked by democratic experiments designed to break the stranglehold of authoritarianism on the country. Narrowing the dislocations between the disparate communities of Iraq was a crucial aspect of this task. As the Kurds have engaged in an almost constant rebellion against Baghdad since the establishment of modern Iraq in 1921, the political, administrative and cultural gap between the north and the rest of the country was a constant reminder of Iraq's failure to establish an inclusive, democratic order.

Iraqi rulers often had an inconsistent attitude toward democracy that was clearly discernible in the country's uneven march toward democratic ideals and practices, during which democracy would go through an extended period of denial, and then suddenly allowed to function, only to be denied yet again. ${ }^{113}$ It is no coincidence the relations between the state and the Kurds have been marked by the same attitude, which led successive regimes to recognize Kurdish nationalism and cultural rights for a time, then

\footnotetext{
${ }^{112}$ Dawisha, Adeed (2009). Iraq: A Political History from Independence to Occupation, Princeton, NJ: Princeton University Press, 6.

${ }^{113}$ Ibid.
} 
to deny Kurdish identity again and reinstate strategies of assimilation and control. In this sense, there has always been a striking overlap between the cycles of political openings for Kurds in Iraq and the emergence of political will to stop the armed rebellions in the north through opening negotiations with the Kurds.

The first major political opening in Iraq took place after the coup of July 14, 1958, which put an end to the monarchical rule and marked the beginning of Iraq's transition to a republican state. Issues concerning the position of the Kurds within the state of Iraq quickly became central to the program of action specified by the revolutionaries led by General Abd al-Karim Qasim. The rapprochement between the Kurds and the new regime was largely a result of the common interests shared by the Kurdish movement and the Qasim government. For Qasim, Kurdish support for the new regime was of great value in combatting attempts by the extreme Arab nationalists to displace him. ${ }^{114}$ The Kurdish movement was viewed as a critical ally both by Qasim and his left-wing supporters due to Mulla Mustafa Barzani's distinguished record of armed combat and revolt over several years against the British administration and the monarchy. For the Kurds, Iraq's transition to a republican regime created a political environment conducive for the recognition of their demands for the establishment of democratic freedoms and the realization of the Kurds' political and cultural rights.

The general program drawn up by the new republican government called for the establishment of a democratic regime and the adoption of a new constitution based on freedoms, social justice and recognition of the rights of the minorities within Iraq's

\footnotetext{
${ }^{114}$ Penrose, E. F., Penrose, Edith (1978). Iraq: International Relations and National Development, Boulder: Westview Press, 1978, 338.
} 
national unity. ${ }^{115}$ Within this framework, Qasim legalized the KDP, welcomed Mullah Mustafa Barzani on his return from the Soviet Union where he was in exile since 1945, and removed some of the restrictions that had been placed on Kurdish publications under the preceding regime. ${ }^{116}$ Qasim and his leftist supporters promoted an Iraqi-first identity and tried to create a sense of Iraqiness based on the Kurdish-Arab fraternity. The draft constitution stated, "Arabs and Kurds are partners in the Iraqi homeland and their national rights are recognized within the Iraqi state." 117 Nonetheless, the honeymoon between Qasim and the Kurdish movement did not last long, not only because Qasim shared the preconceptions of his predecessors regarding the Kurdish question, but also because his administration did not manage to progress beyond the very limited elements of representative government established by the preceding regime.

The Kurdish question has an important place in any analysis of the decline of Qasim. The major flaws in Qasim's administration such as his gradual concentration of power and his failure to depart from the entrenched state traditions of authoritarianism soon made it apparent the Kurdish aspirations for autonomy and the restoration of democratic liberties were in fact representing demands which the government in Baghdad was not yet willing to grant to Iraqi Arabs, and so they could hardly grant rights to the Kurds. ${ }^{118}$ Under these conditions, relations between the Kurds and the Iraqi state rapidly deteriorated. The fighting that broke out in 1961 was the start of a prolonged conflict that

\footnotetext{
${ }^{115}$ Marr, Phebe (1985). The Modern History of Iraq, Boulder, Colorado: Westview Press, 155.

116 Vanly, Ismet Sheriff (1993). "Kurdistan in Iraq" in A People Without a Country: The Kurds and Kurdistan edited by Gerard Chaliand, New York: Olive Branch Press, 150.

${ }^{117}$ Dann, Uriel (1969). Iraq Under Qassem: A Political History, London: Pall Mall, 36.

${ }^{118}$ Penrose, 280.
} 
continued intermittently until 1975 . The prolonged war in the north played a significant role in the declining popularity of the Qasim regime and its eventual ouster by the Baathists and Arab nationalist military figures on February 8, 1963.

The next major attempt at a democratic opening in Iraq emerged directly out of the concerns over finding a peaceful solution to the Kurdish problem. In 1966, Abd alRahman al-Bazzaz was appointed as the first civilian prime minister of Iraq since the collapse of the monarchy in 1958. Iraq had been under military rule since 1963 . The appointment of Bazzaz appeared to be a move away from the military ruler regime towards some civilian power, giving the impression a new era of a more open government would be introduced. ${ }^{119}$ Bazzaz himself was an Arab nationalist ideologue, but he recognized the centrality of the Kurdish question to the country's progress and attempted to initiate negotiations to end the war and effect a settlement in the north. On June 29, 1966, he outlined a twelve-point offer to the Kurds that went further than ever before in meeting most of the Kurdish demands. A full acknowledgement of Kurdish nationality was the first of the twelve points followed by the acceptance of the Kurdish language as an official language (along with Arabic) in the provinces that were predominantly Kurdish. The declaration also promised decentralization with freelyelected administrative councils and proportional representation for Kurds in central government. Finally, the government declared its intent to hold parliamentary elections within the period fixed in the provisional constitution. ${ }^{120}$

\footnotetext{
${ }^{119}$ Al-Marashi, Ibrahim, Salama, Sammy (2008). Iraq's Armed Forces: An Analytical History, New York: Routledge, 100.

${ }^{120}$ Penrose, 340.
} 
With the al-Bazzaz government came a valuable opportunity to consider the Kurdish question in the context of a workable plan of reconciliation. ${ }^{121}$ More importantly, al-Bazzaz's efforts to end the war in the north went hand-in-hand with efforts to establish a genuine representative government as he understood that democratic order cannot be discussed without confronting the bi-national character of Iraq. In this respect, the Bazzaz Declaration was a crucial initiative in that it addressed two requirements necessary to resolve the Kurdish question in Iraq: autonomy for the Kurds and an electoral parliamentary democracy for all Iraq. ${ }^{122}$ However, the al-Bazzaz government was short lived because the military rulers rejected any concession to the Kurdish nationalist demands. With his departure in August 1966, the best chance for both the Kurds and a democratic republican Iraq disappeared.

Before 1991, the final episode of rapprochement between the Kurds and the state took place under the most coercive regime in the modern history of Iraq. On assuming power in 1968, the Baath regime launched a program intended to take over all of Iraq's social and political institutions and organizations, and used violence on a scale unmatched in Iraq's history in order to suppress all of its opponents. ${ }^{123}$ In this context, the Kurdish war in the north was troublesome in light of both the Baath determination to take "full" control of the country and the wish of the ruling civilian faction of the Baath to free itself from its dependence on the army. In the meantime, as the efforts to suppress the

\footnotetext{
${ }^{121}$ Ibid. 341.

${ }^{122}$ McDonald, 318.

${ }^{123}$ Eppel, Michael (2004). Iraq from Monarchy to Tyranny: From the Hashemits to the Rise of Saddam, Florida: University Press of Florida, 254.
} 
revolt and isolate Barzani failed, the government in Baghdad decided, as Abd al-Rahman al-Bazzaz had before them, that for Iraq to become strong the Kurds had to be accommodated and decisively brought into the national fold. ${ }^{124}$

On March 11, 1970, the Baghdad government declared a far-ranging agreement with the Kurds. The agreement recognized the Kurdish nationality and promised linguistic rights, Kurdish participation in the government and appointment of Kurdish governors in the mainly Kurdish areas. ${ }^{125}$ Most controversially, Article 14 of the agreement stated that "appropriate measures will be taken to unify the mainly Kurdish districts and administrative units, as established by official statistics drawn up for the purpose. ${ }^{, 126}$ In this way, the government promised self-government for the Kurds and decided the territorial extent of the Kurdish autonomous area would be determined through a population census. During the years following the agreement, Article 14 remained the main obstacle to the agreement's implementation as Baghdad was determined to ensure that the major oil-producing areas of Kirkuk and Mosul remained outside Kurdish control. Thus, the period of Kurdish-Baath amity that emerged in the early 1970s, withered away quickly given the sluggish pace of negotiations. However, the legacy of the 1970 agreement continued until the 1990s, and laid the foundations of decentralized government in Iraq.

\footnotetext{
${ }^{124}$ Romano, David (2006). The Kurdish Nationalist Movement: Opportunity, Mobilization and Identity, New York: Cambridge University Press, 192.

${ }^{125}$ Stansfield, Gareth (2007). Iraq: People, History, Politics, Cambridge: Polity Press, 104.

${ }^{126}$ Vanly, 155.
} 
The relationship between the Kurds, the state and democracy in Iraq was never straightforward. Successive regimes attempted to give concessions to the Kurds, not out of genuine concerns for democracy, but mainly to accomplish their own political interests. Although there was no formal link between the Kurdish issue and the question of restoring representative government in Iraq, it was impossible to accommodate the Kurdish demands for autonomy and cultural rights without opening up the system to embrace diversity and dissent. Thus, the episodes of formal negotiations between the Kurds and the governments in Baghdad always act as a catalyst in pushing successive regimes to consider the broader question of democracy in Iraq.

Well aware democratization in Iraq was necessary to accomplish their goals, the Kurds persistently emphasized the importance of democratic order in Iraq as the primary precondition for the implementation of their identity demands. In this respect, they took strategic advantage of Baghdad's politicians' need to broaden support for their governments and pressed ahead the Kurdish agenda for greater rights and autonomy. Maintenance of military discipline among contentious Kurds, which was mainly a consequence of the tribal power configurations, enabled the Kurdish movement to constantly challenge the central government and strengthen their political leverage and negotiating power. The professional-intellectual wing within the movement, despite its competing agendas, often acted in concert with the tribal leaders in the face of extreme government coercion and played a significant role in building up the organizational capacity of the movement. The Kurdish movement in Iraq suffered severely from intraKurdish conflict, but often the opposing party organizations cooperated to protect the interests of the Kurds of Iraq. When the opportunity manifested itself in 1991, both the 
KDP and the PUK, despite their limitations, were ready to govern Kurdistan with their established social bases, and administrative and military capabilities.

\section{Autonomous Kurdistan: An Opportunity for Democracy}

From 1991 until the United States-led coalition invasion of Iraq in 2003, the Kurdish region of Iraq remained largely insulated from the rest of the country economically and politically. Until 1991, the cycles of Kurdish rebellion in the north paradoxically encouraged both a central government with strong coercive powers and an open government responsive to the demands of its citizens. Given the entrenched role of the military in Iraqi political life and the powerful tendency for politics to be seen as a way of disciplining the population, democratic experiments in Iraq never culminated in genuine political change. Nevertheless, the rulers' commitment to ensure conformity with their visions of social order was constantly interrupted by successive revolts in the north, which occasionally gave way to the emergence of leaders willing to open up the political system and make deals with the Kurds. The establishment of a de facto autonomous zone in the north practically eliminated this dynamic in the relationship between the Kurds and the state.

The 1991 Gulf War virtually put an end to the Kurdish armed struggle in Iraq, which had defined the relationship between the Kurds and the Iraqi state more than half a century. Following the defeat of 1991, as testimony to the resilience of the system he has constructed, Saddam Hussein's regime and much of his ruling circle remained largely intact. The power of the regime in Baghdad was not much affected by the emergence of 
an autonomous Kurdish entity in the north. ${ }^{127}$ For the Kurds, on the other hand, state repression ceased to be a major threat in the virtually independent area under Kurdish control, which was protected from interference by the central government through a sterile U.S. containment policy against Saddam Hussein. Over the years following the Gulf War, the Kurdish region, historically one of Iraq's most conflict-ridden and underdeveloped areas, has emerged as the most stable, secure and prosperous region by far. While the creation of a safe haven and subsequent development processes widened the social, political and economic gap between the north and the center, and were seen as a precursor to Kurdish statehood, the same processes became the very reason why the fate of the Kurds became tied to the future of Iraq and the establishment of a stable democracy in the country.

The emergence of Iraqi Kurdistan as an autonomous entity in 1991 was not an unintended consequence of the defeat of Saddam Hussein in the Gulf War. The intermittent guerilla war that the Kurds themselves conducted against the central government, as well as the political cohesion and organizational capacity they built over the decades, shaped the turn in fate for the Kurds of Iraq as much as the major wars that were fought in the region. At the end of 1991, Saddam Hussein, content that the international community, particularly the US and Turkey, would never support Kurdish secessionism, withdrew the Iraqi army from Kurdistan. Saddam was right in anticipating the international reaction to the possible establishment of a Kurdish state, but his decision to pull out of Kurdistan was based on two erroneous assumptions. First, he believed the

\footnotetext{
${ }^{127}$ Tripp, 254.
} 
Kurds would not be able to survive without the services of the central government and would rush quickly back to the control of the Baathist state. Second, he thought the world would remain indifferent to the fate of the Kurds, as had been the case after the Anfal campaign in $1988 .{ }^{128}$ Saddam was wrong on both counts. Kurdistan managed to survive economically and politically as a result of the combined effects of a number of factors.

The emergence of Kurdish autonomy in Iraq was a direct outcome of the enhanced international humanitarian awareness of the Kurdish plight. The subsequent economic survival and sustainability of Kurdistan was also made possible through the vast amount of international aid flowing into the region, which encouraged relative stability, economic recovery and rehabilitation under the difficult post-war conditions. The external support for Kurdish autonomy has been tied largely to the international commitment to keep Iraq "as a whole." However, humanitarian relief to the Kurds was also linked to larger transformations in international politics in the post-Cold War era that challenged the notion of state sovereignty and focused on protecting local populations on human rights principles and demands for post-conflict recovery. ${ }^{129}$ The installation of a no-fly zone and the subsequent economic support to the Kurds derived in large part from the strategic interests of the US and foreign governments to protect world petroleum markets and contain the Iraqi government. Nevertheless, it was also a result of the international attention and recognition won by the Kurdish cause, compounded by the

\footnotetext{
${ }^{128}$ Bengio (2005). 178.

${ }^{129}$ Natali (2010). 30.
} 
emergence of a "new humanitarianism" in the 1990s based on the promotion of programs of support for democracy and human rights in conflict-ridden societies. ${ }^{130}$

Saddam expected his regime would return to Kurdistan soon after the end of the war. In early 1992, he imposed a complete economic blockade on the Kurdish region leading to a double embargo for the Kurds as Iraq was already subject to the United Nations sanctions. Under those conditions, humanitarian aid became the most important source of the region's external finances. Over time, the UN's difficulties in operating freely in Saddam-controlled regions of central and southern Iraq as well as the doubts concerning the proper monitoring or accountability for aid given for projects in government-controlled areas led to the emergence of development differentials across regions of the country. ${ }^{131}$ While the Saddam-controlled, aid-restricted regions experienced spiraling inflation, political instability, and socioeconomic decline, the Kurdistan region enjoyed certain levels of economic revival and assured some basic needs for the local population. ${ }^{132}$ During the regime's last decade, the status-quo in Iraq remained largely unchanged, but the economic and political progress made by the Kurdistan region since 1991 came back to haunt the post-Saddam era, providing the Kurds with strong leverage over the debates on building a more inclusive political system in Iraq.

\footnotetext{
${ }^{130}$ Barakat, Sultan (2005). "Post-War Reconstruction and Development: Coming of Age" in After the Conflict: Reconstruction and Development in the Aftermath of War edited by Sultan Barakat, London: I. B. Tauris, 9-10.

${ }^{131}$ Brown, Sarah Graham (1999). Sanctioning Saddam: The Politics of Intervention in Iraq, New York: I. B. Tauris, 275-279.

${ }^{132}$ Natali (2010). 31.
} 
If international financial support played a major role in Kurdistan's economic survival, it is the power of Kurdish nationalism as an ideological force that ensured the endurance of Kurdistan politically. After Baghdad pulled out of the Kurdish region, Saddam informed the legion of Kurdish civil servants they had to relocate to Iraqi government territory or lose their salaries. ${ }^{133}$ But the Kurds stayed. The government withdrew its administrative units and personnel from Kurdistan, cut off the salaries to Kurdish employees, and imposed an internal embargo on the region, creating a unique administrative and legislative vacuum that paralyzed civil operations in Kurdistan. The Kurds, however, were determined to take up this challenge because the "Kurdish ethnicity" had become a deeply entrenched valued good in Kurdish society after the decades-long struggle against the central government. This is why the commitment to Kurdish self-rule was no longer up for compromise, however costly the pursuit of its realization.

Indigenous Kurdish political and administrative systems were established immediately after the events of 1991 . The Kurdish political leadership, dominated by the KDP and the PUK, quickly took the initiative to fill the political vacuum created by the withdrawal of the Iraqi central government's presence in the north. Multi-party elections occurred on May 19, 1992, resulting in the establishment of the Kurdistan Regional Government and a power sharing system between the KDP and PUK. In the years following the April 1992 elections, serious problems remained in Kurdistan, notably the internecine fighting between the two main parties, but the Kurds' point of comparison -

\footnotetext{
${ }^{133}$ Lawrence, Quil (2008). Invisible Nation: How the Kurds Quest for Statehood is Shaping Iraq and the Middle East, New York: Walker \& Company, 62.
} 
as Iraq was severely damaged by the authoritarian rule of Saddam Hussein since 1979 set a very low standard. For all their problems of divided government and internal mistrust, the Kurdish progress over governing an area that was almost completely destroyed by war with a population numbering as many as 5 million, was noteworthy. ${ }^{134}$ The April 1992 election was one of the most democratic to be held in the Middle East and had a significant turnout, which was both an unambiguous sign of the population's awareness of the importance of democratic principles and a protest against Saddam's regime. $^{135}$

The economic and political development in the Kurdish region after 1991, and notably since the end of Kurdish infighting in 1997, has been held up as a demonstration that establishing an open and plural politics in Iraq is possible. ${ }^{136}$ In this respect, particularly after the American invasion of Iraq, the question of whether the de facto autonomous region in the north could provide a model for future democratic state of Iraq gained prominence. The answer to this question is tied to two distinct but interlocked processes: democracy in Kurdistan and the relations between the Kurds and Baghdad in the post-Saddam era.

\section{Political Development and Emergent Democracy in Iraqi Kurdistan}

The prospects of overthrowing Saddam Hussein's regime were weak until the emergence of a possible confrontation between the U.S. and Iraq in 2002. In this context,

\footnotetext{
${ }^{134}$ Stansfield, Gareth (2005). "Governing Kurdistan: The Strengths of Division” in The Future of Kurdistan in Iraq edited by Brendan O'Leary, John McGarry, Khaled Salih, Pennsylvania: University of Pennsylvania Press, 200.

${ }^{135}$ Hoff, Ruud, Leezenberg, Michiel, Miller Peter (1992). Elections in Iraqi Kurdistan: An Experiment in Democracy, Brussels: Pax Christi International, 11.

${ }^{136}$ Tripp, 258.
} 
and in the face of the still powerful status quo in Baghdad and weak and fragmented Iraqi opposition, the Kurds focused on establishing a self-governing region in the north with a functioning democracy and decent living standards. With the changes taking place in the region and the growing possibility of a change of regime in Baghdad in 2003, the fears and ambitions regarding the future of Kurdistan grew as well. Considering the economic and political progress made since 1991 as well as the opportunities offered by major military action against Baghdad by the U.S., the Kurdistan Regional Government raised the political stakes in post-Saddam negotiations, moving from limited local autonomy to a more ambitious federal system of government. Besides the intersection of U.S. interests with those of the Kurds, it was the claims over the success of the "Kurdish democratic experiment" that led the Kurdish leaders to be more assertive regarding the Kurdish demands in the post-Saddam era. While those claims have merit, their validity cannot be confirmed unless the questions of how successful the experiment was and how sustainable it is are answered.

In 1992, the Kurds declared the establishment of a federal democracy in Iraq to be their goal. When a de facto autonomous region emerged in the north in 1991, the two biggest challenges facing the Kurds were, first, Kurdish unity, specifically, dissolution of the rivalry between the KDP and PUK, and second, the concerns of the neighboring countries (Turkey and Iran in particular) over the emergence of an independent Kurdish state in northern Iraq. Kurdish unity, which was fundamental to the empowerment of the autonomous Kurdish entity, was ironically frightening the surrounding countries and provoking their intervention. The way to overcome this dilemma was determined to be the Kurdish adherence to the idea of a democratic, federal and unified Iraq, which would 
both mitigate the concerns over territorial integrity of Iraq and preserve the Kurdish entity within a democratic framework.

In October 1992, the Kurdistan National Assembly announced the unanimous commitment of Iraqi Kurdistan "to determine its fate and define its legal relationship with the central authority at this stage of history on the basis of a federation within a democratic parliamentary Iraq." ${ }^{137}$ The October 1992 resolution recognized both the Kurds' right to self-determination and the territorial integrity of Iraq, fulfilling the two main requirements for ensuring the economic and political success of Kurdistan. Nevertheless, the deep-seated problems within the Kurdish political scene soon sprang up to militate against the chances of ultimate success, the most serious of which was a crippling episode of internal fighting.

Democracy in Kurdistan is primarily related to the multi-party politics as the political position in the region results largely from the way in which the two major political parties evolved. Successive rounds of civil war between the KDP and PUK created a significant obstacle to the establishment of a coherent democratic structure and led to major problems in the region including the use of violence in pursuit of political ends, corruption, the division of society along established political cleavages and external intervention. This situation inevitably highlights a question about the extent to which a system characterized by a fundamental divide can truly provide a model for the rest of Iraq, which already suffered from severe social, political, ethnic and sectarian divisions.

\footnotetext{
${ }^{137}$ Voice of the People of Kurdistan Radio, October 5, 1992. Quoted in Bengio, Ofra (Summer 2003). "Iraqi Kurds Hour of Power," Middle East Quarterly, 10 (3): 39-48.
} 
Faced with the necessity of having to form an administration in the aftermath of the withdrawal of government forces in 1991, the political parties of the Kurdistan region struggled to come to terms with their newfound territorial authority. ${ }^{138}$ For decades, the Kurds were against law and order, and fought against the state. Changing from guerilla fighters to statesmen was not an easy task. Still, in 1992, Kurdistan's voters showed they had both the desire and the ability to govern themselves by electing a National Assembly. However, the power sharing system devised to both provide an administration for the region and satisfy the KDP and PUK simply did not solve the historical enmity deriving from deep-rooted political grievances and mutual mistrust between the two parties.

Until 1997, neither party displayed the ability to manage their rivalries in a peaceful manner, and resorted to military options that made the possibility of any stable joint government extremely unlikely. ${ }^{139}$ Moreover, the use of arms inevitably made the parties look beyond the Kurdish region for support, which paved the way for external intervention. The KDP established working relations with Turkey, which needed the KDP in order to destroy the PKK bases in northern Iraq. Meanwhile, the PUK turned to Iran for military support, which led the KDP to ask military assistance from the Iraqi government. American concern about the re-establishment of Saddam Hussein's control in the north as well as the intervention of Iran into Iraqi territories eventually resulted in the U.S.-mediated Washington Agreement of September 1998, which ended the fighting between the KDP and the PUK.

\footnotetext{
${ }^{138}$ Stansfield, Anderson (2010). 3.

${ }^{139}$ Ibid. 5.
} 
The situation in Kurdistan until 1997 clearly revealed the difficulties associated with the Kurdish parties' ability to "govern" due to their roots as armed opposition groups. Rather than viewing the first half the 1990s as an "incompetency" brought about by the evolution of the Kurdish movement as a predominantly military struggle, it is perhaps more correct to see it as a period of development toward the maturity of the Iraqi Kurdish political system and parties. Following the Washington Agreement, Kurdistan was divided into two executive jurisdictions controlled by the KDP and the PUK, respectively. The divided political system, despite casting a shadow of apprehension over the future of a unified Kurdistan government, paradoxically allowed the parties to manage their differences while gaining the experience, knowledge, and skills necessary to turn Kurdistan around. ${ }^{140}$ As awkward and cumbersome as the divided government appeared to be, the stability achieved by the division of power enabled both parties to manage the domestic affairs of their respective regions more efficiently and develop their administrative capacities. Since 1997, there has been an increasing trend toward reconciliation and cooperation as the two parties focus on being governments rather than parties.

Despite the political turmoil of the mid-1990s and the subsequent territorial division of Kurdistan, one might still argue that a more democratic and pluralistic system prevailed in the north as compared to the one-party totalitarian state in Baghdad whose pervasive apparatus of surveillance and repression remained largely intact even during the 1990s. The Washington Agreement explicitly recognized the multi-ethnic

\footnotetext{
${ }^{140}$ Stansfield (2005), 199.
} 
composition of the Kurdish region and thus of Iraq as a whole, placing the aspirations of such groupings as the Turkmen, Assyrians and the Chaldeans on an equal footing with those of the Kurds. ${ }^{141}$ Since 1991, all the cabinets of Kurdistan included the members of ethnic and religious minorities through the enforcement of certain minority quotas. The more open and liberal atmosphere has allowed the entry of new political forces, including the formation of parties representing other ethnic and religious groups in the region such as three separate Turkmen parties, the Islamic Movement of Kurdistan and its more radical Islamist offshoots, as well as Assyrian and other Christian parties. ${ }^{142}$

Since 1997, the experiences Kurdistan offer proof that Iraqis, who had been deprived of any meaningful democratic experience for decades, can embrace democratic principles and norms. The process of reconciliation in Kurdistan gained pace particularly after the U.S.-invasion of Iraq, which galvanized the Kurdish leaders to plan carefully their future course of action and coordinate their efforts both in their political negotiations with Baghdad and in how they govern Kurdistan. These efforts brought about major accomplishments for the Kurds, the most notable of which was the formal recognition of the Kurdistan Region as a legitimate entity of the state. ${ }^{143}$ The Kurdistan Regional Government Unification Agreement of January 21, 2006 further strengthened the legitimacy of the Kurdish politicians and consolidated the Kurdistan Region as an

\footnotetext{
${ }^{141}$ Tripp, 258.

${ }^{142}$ Ibid.

${ }^{143}$ Stansfield, Gareth (2010). "From Civil War to Calculated Compromise: The Unification of Kurdistan Regional Government in Iraq" in The Kurdish Policy Imperative edited by Robert Lowe, Gareth Stansfield, London: Chatham House, 138.
} 
institutionalized reality in the Middle East. It was also a major step towards putting an end to the exploitation of differences between the KDP and PUK by the regional powers.

Iraqi Kurdistan has come a long way for the last two decades, but it would be a mistake to exaggerate the levels of development that occurred in the region. Even though the KRG became a mixed cabinet following the unification agreement, the political power in the region remained divided between two poles. Both the PUK and the KDP have been exposed to criticisms on the grounds that they continue to put their separate party interests before the interests of the KRG and that even the opposition parties are actually on the payroll of the two main parties in the region. ${ }^{144}$ The establishment of a joint government provided hope that the disputes between the KDP and PUK would be solved, and the KRG would better serve the collective and public interest. However, the new unified arrangement generated concern among the smaller parties that the PUK and KDP might have absolute power in Kurdistan and narrow the democratic process by hindering the establishment of any opposition in the region. ${ }^{145}$

Despite its distinct course of development, Iraqi Kurdistan shares many structural features with the country as a whole. While the region has enjoyed enhanced economic prosperity over the past two decades, the regional elites have maintained their patronclient networks by relying on the same structures that materialized during their resistance to the Baath rule. ${ }^{146}$ The PUK and the KDP negotiated successful development programs

\footnotetext{
${ }^{144}$ Leezenberg, Michiel (2005). "Iraqi Kurdistan: Contours of a Post-Civil War Society," Third World Quarterly, 26 (4/5): 640.

145 "Views differ on PUK-KDP Agreement," Kurdish Globe, August 8, 2007.

${ }^{146}$ Von der Osten-Sacken, Thomas (March 2006). "Working Paper: Iraqi Kurdistan; a Model for Iraq?" Presented to the ASPEN Conference: Greater Middle East, Doha, Qatar.
} 
with the United Nations and international nongovernmental organizations through their share of the "Oil-for-food" program, which played an important role in the economic development of the region throughout the 1990s. However, this situation created important challenges for Iraqi Kurdistan similar to those facing many authoritarian societies based on wealth through oil. Despite the achievement of a great deal of economic progress, this growth remained vulnerable given the increasing dependency on oil and gas, particularly after the realization that the region cannot continue to count on international aid to maintain its economic growth.

Contemporary Iraqi Kurdistan is not quite a rentier state (or quasi-state) in the classical dependency-theoretical sense of the word. Nevertheless, the growing oil sector, combined with Kurdistan's position as a "post-civil war society," resulted in certain structural problems whereby the heritage of domestic conflict strengthened, and even institutionalized, the patronage relations in the region. ${ }^{147}$ Instead of the KRG, the control over important sectors such as oil, gas, telecommunications, construction and trade remained in the hands of the PUK and KDP or other allied political groups. ${ }^{148}$ The wealth acquired through international aid and oil has not been distributed among the Kurdish cities equally due to the two major parties' tendency to spend most of the funds for the benefit of their respective spheres of influence. Thus, economic inequality remains a major problem as not all people have been able to profit from Kurdistan's newlyachieved prosperity. Smaller political parties, independent civil society organizations and

\footnotetext{
${ }^{147}$ Leezenberg, 640.

148 Jabary, Kawa, Hira, Anil (Summer 2013). "The Kurdish Mirage: A Success Story in Doubt," Middle East Policy, 20 (2): 106-107.
} 
the media have largely failed to act as checks over the larger parties due to the institutionalized patronage and policies of cooptation that cut across the state-society relations. This situation significantly weakened the chances for genuine democracy in the region and instead, consolidated the perception of the KRG as "Barzani-stan" and "Talabani-stan."

This institutionalized patronage gradually increased the mistrust of the KRG and its institutions among the Iraqi Kurdish populations. The PUK and the KDP have been able to maintain their legitimacy in the eyes of the Kurdish public in large part because of their leadership role within the resistance against decades of totalitarian rule and violent repression in the north. Since Saddam Hussein's overthrow in 2003, however, it has become increasingly apparent the people of Kurdistan are not satisfied with the authorities in power and now demand for the elimination of institutionalized clientelism and corruption.

The first popular expression of dissatisfaction with the ruling parties appeared in March 2006 when hundreds of protestors took to the streets on the anniversary of Halabja gas attack, expressing anger at what they view as corruption, nepotism, and a lack of transparency within the KRG, and particularly within the two predominant political parties. ${ }^{149}$ March 2006 protests were the most serious popular challenge to the political parties that have ruled Kurdistan for the past fifteen years and conspicuously highlighted

\footnotetext{
${ }^{149}$ See Amnesty International, "Iraq: Hope and Fear; Human Rights in the Kurdistan Region of Iraq," April 14, 2009; Qadir, Kemal Said (2007). "Iraqi Kurdistan's Downward Spiral,” Middle East Quarterly, 14 (3): $19-26$.
} 
the growing tension between the local Kurdish communities and the KRG. ${ }^{150}$ Likewise, a series of demonstrations and riots against the KRG occurred in 2011 in the city of Suleymaniyah, demanding an end to corruption and social injustice, and asking for the resignation of the cabinet and the disbanding of the KRG. The protests were inspired by the pro-democracy uprisings sweeping the Arab world and organized by the Goran (Change) Movement, a major opposition party founded in 2009. After more than two months of daily protests, the demonstrations were crushed by the security forces, which opened fire and detained protesters, actions that received heavy criticism from Amnesty International and Human Rights Watch. ${ }^{151}$

The problem that has prevailed in Kurdistan since 1991, is that the creation of a functioning government in the region remained a top-down process involving the elites of the two major political parties and external actors, particularly the United States. Ordinary people living in the Kurdistan region exercise very little influence over the form or substance of the government. ${ }^{152}$ Although the people of Kurdistan in principle from 1991 to 2003 largely supported this undertaking, the fact that the regional authorities held significantly more power than ordinary citizens gradually created a clear set of local grievances and demands for renegotiating the terms of the relationship between the authorities and local people.

\footnotetext{
${ }^{150}$ Worth, Robert F. "Kurds Turn Violent in Protest Against Their Leaders," The New York Times, March $16,2006$.

${ }^{151}$ See Amnesty International. "Days of Rage: Protests and Repression in Iraq," April 12, 2011; Human Rights Watch. "Iraqi Kurdistan: Growing Effort to Silence Media," May 24, 2011.

${ }^{152}$ Watts, Nicole F. (2012). "The Role of Symbolic Capital in Protest: State-Society Relations and the Destruction of the Halabja Martyrs Monument in the Kurdistan Region of Iraq," Comparative Studies of South Asia and the Middle East, 32 (1): 71.
} 
Kurdistan holds promise for the future. Although the major political parties of the KDP and PUK focused primarily on preserving their own power base within the region, they also acknowledged the necessity of embedding more democratic procedures in order to ensure both internal legitimacy and external support for the Kurdish cause. After the 2006 protests in Halabja, increasing government responsiveness to the demands of the citizens created an expanded political space with more active civil society involvement. During the post-protest mobilization process, many of the people associated with the opposition media and NGOs became important players within the new Goran Party, which formed in 2009 as a break away from the PUK over issues about transparency in government, accountability, and corruption. ${ }^{153}$ Following the 2011 protests organized by Goran, both the KDP and PUK leaderships declared their recognition of the people's right to protest and the legitimacy of their demands. ${ }^{154}$ Goran won nearly a quarter of the votes in the Iraqi Kurdistan parliamentary elections of July 2009, and mounted a serious challenge to the monopoly of power of the two main parties. In the 2013 parliamentary elections, Goran gained even more votes and won the second-most seats in the parliament after the KDP, bumping the PUK in the third place. After the elections, the PUK announced that it respected the results and "denying the people's will would be shameful. ${ }^{, 155}$

Increasing competition between the KDP and PUK and the emergence of a new, more vigorous Kurdish opposition, definitely presents challenges for stability in

\footnotetext{
${ }^{153}$ Watts (2012). 85.

${ }^{154}$ See "Massoud Barzani's Response to protests in Iraqi Kurdistan," Ekurd.net, February 27, 2011; "Talabani acknowledges protesters and MP vote on their demands," Ekurd.net, March 18, 2011.

155 “PUK Falls to Third Place in Iraqi Kurdistan Elections," Al-Monitor, September 27, 2013.
} 
Kurdistan. On the other hand, a growing understanding among the parties regarding the rules of political competition looks promising in terms of effective promotion of democracy and expansion of multi-party involvement in the region. It is important to note that many of the difficulties facing post-Saddam Iraq are similar to those facing Iraqi Kurdistan since 1991. If there is one clear lesson to be learned from the experience of the Kurds, it would be that embarking on a competitive multi-party democracy without considering the multiple fault lines in political, ideological, ethnic and sectarian terms in divided societies is potentially disastrous. This lesson proved pertinent for the whole of Iraq in the post-Saddam era, confirming that the development of political framework underpinned by consensus regarding the rules of political competition is not possible without political reconciliation between various ethno-sectarian groups in Iraqi society.

\section{Relations between the KRG and Baghdad in the Post-Saddam Era}

Besides the shortcomings of the model of governance and democracy in Iraqi Kurdistan, the question of whether Iraqi Kurdistan can become a model for the rest of Iraq is important especially when one considers the Kurdish movement is the most influential component of the Iraqi opposition. Until 1991, the Kurds' position in Iraq's internal opposition took the form of armed struggle, which played an important role in forcing successive Iraqi regimes to make concessions on issues regarding democracy, governance, and political participation. However, those concessions never turned into permanent measures or spurred real political change in Iraq because of the deeply entrenched authoritarian structure of the state.

When regime change became imminent in Baghdad in the aftermath of the American invasion of Iraq in 2003, Iraqi Kurdistan had been without any direct link to 
the central government for more than a decade. After the removal of Saddam Hussein's regime, the Kurdish leaders "returned" to Iraq to participate in the negotiations concerning the Transitional Administrative Law (TAL) after more than a decade of de facto sovereignty. However, this time, Iraq's diverse ethnic and religious groups had a unique opportunity to redefine, negotiate and reshape the state on new bases of legal plurality and decentralization. It was in this context the Kurds once again took up their role as the core element of the internal opposition in Iraq and their role became central to the questions of democracy and federalism in the country in the post-Saddam period.

The emergence of Iraq as a federal state after the regime change was in part a consequence of the American views of the larger question over Iraqi identities. However, the form federalism took in Iraq as it was accepted in the 2005 constitution was mainly the outcome of dedication and active participation by the Kurds in both the Iraqi Governing Council and the transitional Iraqi government, which lasted from June 2004 to the January 30, 2005 elections. ${ }^{156}$ Given their accumulated power and experience with administration and organization over a decade, the Kurdish parties operated with increased leverage over the Arabs in shaping the constitutional negotiations.

The Kurds were never seen as a strategic asset by the U.S. despite the important role they played in ousting Saddam Hussein from power. After the victory of the U.S. it soon became apparent that this role was a transient one. The fact the U.S. refrained from publicly supporting the planned federation pushed the Kurdish officials to intensify their efforts to fine-tune the concept of federalism, which they envisioned in 1992 for the new

\footnotetext{
${ }^{156}$ Ahmed (2006). 153.
} 
Iraq and reiterated during the Iraqi opposition conference in London in $2002 .{ }^{157}$ The TAL, and later on, the permanent constitution of Iraq acknowledged the legal status of the KRG and recognized the Kurdistan region as one of the federal units in Iraq. Nevertheless, the nature of the federation, but more precisely, the question of whether federalism will strengthen the state and national unity in Iraq or continue to be a source of division, remained to be the main cause of tension and negotiation after the ratification of the permanent constitution in October 2005.

\section{The Arab-Kurdish Divide: Challenges and Prospects}

Much of the contention between the Kurds and Arabs in the post-2005 period arises from the status of Kirkuk and the other disputed territories in Nineveh and Diyala provinces, and the KRG's desire to be autonomous in managing its own internal affairs, particularly, its oil resources. The 2005 constitution lays out a process of resolving the status of Kirkuk and the other disputed areas, but it has remained dysfunctional to date because of profound differences over interpretation and the lack of political will. ${ }^{158} \mathrm{~A}$ referendum in Kirkuk was supposed to have been held in 2007 in accordance with the Article 140 of the constitution, but has been put off indefinitely by Baghdad. From the perspective of the Kurds, this is an indication of the central government's antidemocratic, sectarian, centralizing and unconstitutional behavior, which threatens the fragile democracy in Iraq and opens the way for inter-communal conflict. ${ }^{159}$

\footnotetext{
157 Political Statement of the Iraqi Opposition Conference in London. December 14-16, 2002. http://www.kurdmedia.com/article.aspx?id=8850 (Accessed November 20, 2013).

${ }^{158}$ International Crisis Group, "Iraq and the Kurds: Confronting Withdrawal Fears," ICG Middle East Report 103, March 28, 2011, ii.

${ }^{159}$ Park, Bill (2012). "Turkey, the US and the KRG: Moving Parts and the Geopolitical Realities," Insight Turkey, 14, (3): 109-110.
} 
The prosperous, autonomous Kurdish oil market is the greatest factor in instigating political feuds and complicates the status of Kirkuk. In this regard, the Kurdish attempts to make separate oil deals with foreign governments and international oil companies plays the role of both stabilizing and spoiling the political process in Iraq. ${ }^{160}$ On the one hand, the Kurdistan's region's economic empowerment through oil exports may force the Prime Minister to engage in serious negotiation regarding the disputed territories and Iraq's oil policy, which would strengthen the commitment to power sharing and the creation of a more inclusive political dialogue. In addition, the economic opportunities offered by the growth of Kurdistan's oil and gas industry have greatly encouraged economic and political cooperation with regional states, particularly Iran and Turkey. These alliances helped stabilize the KRG's shared borders, which have been historically conflict-ridden areas because of the Kurdish problems in the neighboring states.

On the other hand, the KRG's nationalist ambitions and efforts to strengthen the autonomy of the Kurdistan region makes it a potential political spoiler because of the challenge the KRG poses upon the Iraqi government's own state-building efforts to consolidate its authority and territorial integrity. ${ }^{161}$ In this regard, the decisions annexing Kirkuk to Kurdistan and permitting the KRG to be autonomous in managing its own oil resources were viewed by the Iraqi government as Kurdish political overreaching, and as increasingly maximalist demands.

\footnotetext{
${ }^{160}$ Natali, Denise (Summer/Fall 2003). “The Kurdistan Region of Iraq: Stabilizer or Spoiler?," Georgetown Journal of International Affairs, 71-72.

${ }^{161}$ Ibid.
} 
The authoritarian policies of the Baghdad government, headed by the Prime Minister Nouri Al-Maliki, were slowly unfolding since the beginning his first term in the office in 2006, particularly given his attempts to fill the ranks of the security and intelligence services with loyalists and to create constitutionally unregulated structures to by-pass the parliamentary approval requirements for the selection of top officers. The Kurds supported Al-Maliki during his first term in order to achieve stability for the fragile coalition government and they helped him survive several political challenges in 2006 and 2007, not only from Sunni Arab factions, but also from within his own Shia community. ${ }^{162}$ Yet, the Kurds began to break with Maliki as the Prime Minister's efforts to stamp his authority on the Iraqi government and to bring Iraq's security and intelligence services under his direct control reached its peak by the end of 2008. When the Sunni-Shia tensions led to nine months of political gridlock over the formation of the new Iraqi government following the March 2010 parliamentary elections, it was the critical role played by the Kurdish parties that resolved the impasse and ensured a second term for Maliki.

Although the Shia bloc in Iraq is more willing to play along with the emphasis on consensus and power sharing in the new political order as compared to the Sunnis, both the Shia and the Sunni political groupings disfavor the federal structure in Iraq which limits the power of the central government and provides the Kurds with greater say in Iraqi politics. The Kurdish parties, therefore, refrained from embracing a specific party or candidate from among either the Shia or Sunni-backed contenders to lead the new

${ }^{162}$ Katzman, Kenneth. "The Kurds in Post-Saddam Iraq," Washington, DC: Congressional Research Service, October 1, 2010, 6 . 
government in 2010. While Maliki's growing power and authoritarianism was definitely alarming if he were reappointed, a potential Sunni-dominated government was equally worrisome for the Kurds given the Sunni Arabs' decisive advocacy for a strong, centralized government that could lead to the unraveling of the political settlement reached in 2003. Eventually, the Kurds threw their support behind Maliki on three conditions: the governing coalition would be a government of national unity, comprising all the major political blocs in Iraq; the prime minister's authority would be diluted to prevent accumulation of disproportionate power; and negotiations would be resumed, in accordance with the 2005 constitution, on the status of Kirkuk and the other disputed territories, and the long-stalled hydrocarbons and revenue-sharing law.

Maliki accepted the demands of the Kurds by signing a pledge that spelled out key agreements and the terms designed to limit his power. However, once the new government finally coalesced, it became apparent the measures taken to constrain Maliki's grip on power would remain on paper. Maliki tightened his control over the Iraqi state and its security forces by increasing his efforts to centralize power by controlling the strategic ministries, the military, the electoral commission and the economy. ${ }^{163} \mathrm{He}$ also implemented a harsh bureaucratic cleansing campaign against Kurdish and Sunni figures, which undermined the power-sharing system implemented in Iraq after the U.S. invasion.

The Kurdish-Arab relations further deteriorated after the withdrawal of the U.S. forces from Iraq at the end of 2011. The US withdrawal greatly weakened the safety valve that helped manage Arab-Kurdish relations in Iraq since 2003 and left highly

${ }^{163}$ Özpek. 134. 
sensitive and significant issues that have not been resolved on the table, such as the reconciliation between politicized communities, the disagreements over disputed territories, the scope of Kurdish autonomy, oil policy, and the overall nature of the national project. Following the US departure, Maliki's calls for a rewritten constitution that would increase the executive authority of the prime minister's office over regions reflected the growing discrepancy between the centralization policies of Baghdad and the autonomy aspirations of the Kurdistan region. The main driving force behind the attack against the constitution was the view that the Kurds are an existential threat to the territorial integrity of Iraq and that the Kurds' attempts to implement article 140 of the constitution and negotiate an oil law for Iraq illustrate their ultimate aim to secede from the state.

The suspicion about the ultimate Kurdish goals is a consequence of the prevalence of ethno-sectarian-based analysis of Iraqi politics that has existed since the establishment of the modern state of Iraq. As the post-Saddam era paved the way for the furthering of Kurdish autonomy, the possible secession of the Kurds from Iraq became more frequently pronounced by Baghdad and the neighboring governments as well as by academics, journalists and media commentators. Repeated emphasis on this option derived partially from the desire of both the Sunni and Shia Arabs to return to an Iraq dominated by a strong state narrative founded on Arabism, and partially from the failure to think outside the dominant paradigm that national self-determination has only one meaning, a sovereign and independent state.

Since the mandatory period, none of the major Kurdish political forces in Iraq presented independent statehood as an organized political demand. The Kurds had 
founded their political and military struggle on the argument that self-determination does not necessarily entail only one option. As a demonstration of their commitment to new forms of national affirmation beyond statehood, the Kurds developed a perspective in which Iraq was viewed as a state where the devolution of some state competences go hand-in-hand with a meaningful recognition of the Kurds as a distinct national community within a multi-ethnic and multi-religious Iraq. ${ }^{164}$ From this perspective, the 2005 constitution was not a document that set the stage for the eventual Kurdish secession, but a compromise by the Kurds undertaken for the interests of the "new Iraq" and as evidence of the Kurds' commitment to the integrity of the state. ${ }^{165}$ In the same vein, and when viewed from the Kurdish perspective, the actions of the KRG regarding the disputed territories and oil revenues, which are perceived as indications of Kurdish secessionist aims, are simply reactions of the Kurds to Baghdad's refusal to negotiate the territories, revenue sharing and national hydrocarbon law through constitutional means.

\section{The Debate on Federalism}

The adoption of a federal system of government, whereby power is constitutionally divided among different levels of government, is among the most frequently advocated solutions to the problem of managing conflict in divided societies. ${ }^{166}$ However, the challenge lies in the question of how to structure a federation that can alleviate, rather than exacerbate, ethnic and religious divisions. The concerns

\footnotetext{
${ }^{164}$ Salih (2004), 123.

${ }^{165}$ Stansfield and Anderson (2010), p. 142.

166 Anderson, Liam (2008). "The Non-Ethnic Regional Model of Federalism: Some Comparative Perspectives" in An Iraq of Its Regions: Cornerstones of a Federal Democracy edited by Reidar Visser, Gareth Stansfield, New York: Columbia University Press, 205.
} 
regarding the design of federal system and the future of democracy in Iraq bear a substantial resemblance to the concerns raised during the British mandate over how to amalgamate Iraq's diverse peoples into a coherent whole within a representative governance framework. Since the mandatory period, successive regimes in Iraq saw the Arab-Kurdish divide as carrying the greatest potential for undermining Iraq's social and political unity. ${ }^{167}$ The post-Saddam era is no exception.

During the 1920s, the British opted for supporting Arab nationalism in Iraq in order to integrate the peoples of the new state, which only exacerbated the ethnic gap in society and left Iraq's north in a constant state of war until 1991. The American policy towards post-Saddam Iraq, while supporting the creation of a federal government that represents the right of all peoples of Iraq, is fixated on the international commitment to Iraq's territorial integrity, which propels the U.S. policy makers toward favoring recentralization. Thus, in both cases, the external powers' commitment to maintain a strong central government in Baghdad encourages the promotion of the idea of "oneness of Iraq," which eases the sectarian divisions by appeasing pan-Arab opinion, but does not relieve the conflict potential rooted in the ethnic divide.

The Shia grievances in Iraq until the 2003 war and the Sunni grievances in the country in the post-Saddam era are, by and large, similar in nature and have more to do with the distribution of power within the state than the form of governance. The political and economic balance in Iraq, which has been heavily in favor of the minority Sunnis, shifted dramatically after the demise of Saddam's regime and provided the Shia Arabs

${ }^{167}$ See Dawisha, Adeed (2005). "The Prospects for Democracy in Iraq: Challenges and Opportunities," Third World Quarterly, 26 (4/5): 723-737; Yavuz, Hakan (Spring 2004). "Provincial Not Ethnic Federalism in Iraq," Middle East Policy, 11 (1): 126-131. 
with increased access to power due to their demographic majority. Although the Sunnis reacted harshly to their reduced political status, they made common cause with the Shia Arabs in calling for a tight-knit Arab Iraq with a strong central government, as opposed to the Kurdish desire for a loose federation. Iraq's new constitution recognized the majority of the demands by the Kurds. However, the post-2005 political process in Iraq simply transformed the ethnic struggle between the Arabs and the Kurds into a struggle between "centralists" and "regionalists," thus, leaving the problem of Arab-Kurdish divide largely unresolved.

The standard approach to the question of democracy and federalism in Iraq among both the academic and policy communities is that in order for democracy to take root, the federal system in Iraq has to be territorially, not ethnically, based. ${ }^{168}$ In other words, it is argued that a federal system based on ethno-sectarian divisions will entrench communitybased loyalties and lead to civil breakdown by encouraging the citizens' commitment to the "good" of the narrower community rather than to the "general good." The best alternative for Iraq is seen as deemphasizing the particularistic attachments to sect or ethnicity, and establishing a federal system that is decentralized on the basis of territory, and promotes citizenship and constitutional patriotism. Within this framework, the Kurds and their efforts to protect the autonomy of Kurdistan are automatically denounced as a threat to the unity of Iraq.

Iraq's communal divisions might indeed undermine political stability and democratization. However, what threatens the future of democracy in Iraq is not Iraq's

\footnotetext{
${ }^{168}$ See Dawisha (2005); Hakan Yavuz (2004); Democratic Principles Working Group (2002). "Final Report on the Transition to Democracy in Iraq," Washington D. C.; Kanan, Makiya (2003). "A Model for PostSaddam Iraq," Journal of Democracy, 14 (3): 5-12.
} 
communal diversity per se, but how it is managed. The political process in Iraq has long been a scene of life-and-death struggles that formed the texture of a violent and communal politics across the country. ${ }^{169}$ For democracy to flourish in Iraq, the new political order must first address the fear of each community that one group might come to power and impose its interests and goals on the other groups. If Iraq's ethnic and sectarian diversity is managed as matter of pluralism and democratic participation rather than as a divisive factor, then the motivation of each group to limit the power of the other might in fact provide the checks and balances essential to the establishment of a workable and equitable power sharing system. Therefore, the main task is to transform the country's communal diversity from a disintegrating force to an agent for democratic change. For those advocating for a territorial federalism in Iraq, this task can be achieved by emphasizing the "Iraqi" character of the state above all considerations of ethnic or religious affiliation. According to this argument, there is but one "people" in Iraq, the "Iraqi people," which refers to the citizens of the state of Iraq regardless of race, ethnicity, or religion. ${ }^{170}$

This view, while finding resonance among the majority Arab community, invites suspicion among the Kurds as it means relinquishment of their formal status as a separate nationality and the loss of Kurdish identity, distinctiveness and existing rights. There is no doubt the promotion and reinforcement of a shared Iraqi citizenship and identity is crucial for establishing a sustainable democracy in Iraq. However, this approach does not

\footnotetext{
${ }^{169}$ Tripp. 303.

${ }^{170}$ International Crisis Group. "Iraq's Constitutional Challenge," Baghdad and Brussels: ICG Middle East Reports 19, November 13, 2003, 11.
} 
capture the complexities and historical particularities of modern Iraq. Throughout the twentieth century, the barrier to democracy in Iraq was not its ethno-sectarian diversity, but the absence of any meaningful political space for the expression of ethnic and religious identities. Given the long history of ethnic expulsion, coercive assimilation and genocidal action against the Kurds, it is politically unrealistic to expect the Kurds to abandon their long struggle to be recognized as a nationality in exchange for reintegrating into Iraq on the terms of Iraq-first patriotism. A shared "Iraqi" identity can be reconstructed only if it is articulated on the basis of explicit recognition of multiple identities, be they national, religious, or linguistic.

The notion of shared Iraqi citizenship stems primarily from an effort to encourage commitment to "civic nationalism" and "constitutional patriotism," as opposed ethnic nationalism. Nevertheless, it is hard for Iraq to develop into a Western-style liberal democracy as such, given that it does not correspond to the ethnographic realities of the country. There is not just "one" Iraqi people. The Iraqi people are made up of more than one nationality, including Arabs and Kurds, which was recognized even by the Baathists in their March 1970 accord with the KDP, as well as by the provisional constitution of 1958. Both in 1958 and 1970, however, the recognition of multiple nationalities in Iraq and the promise of democracy remained on paper due to the ideological pressure of Arab nationalism. These failed attempts at creating a more open government and finding a peaceful solution to the Kurdish question only resulted in the deepening of Arab-Kurdish divide and consolidation of the authoritarian rule in the country. The route taken by the TAL rightfully serves to manage this division by creating a durable set of political compromises so that Iraq could evolve into a sustainable democracy. Nonetheless, the 
post-December 2005 election era showed that Iraq is still facing the threat of recentralization and sliding back to authoritarian rule.

The constitution adopted in Iraq in 2005 set up a decentralized federation and put forward a very progressive framework of democratic governance, civil rights and freedoms. Apart from the Kurds' strong assertion of federalism, little has been discussed in the country at large about the composition of the new government, particularly the degree of devolution of central power and the definition of the boundaries of the federal units. While the Sunni Arabs were primarily concerned about their marginalized status in the new order, the Shia were eager to claim the political power they believe their majority deserves and was denied for so long under Saddam's Sunni-dominated government. ${ }^{171}$ In this context, the Kurdish parties emerged as the critical "third" players in the postSaddam era, concerned mainly with the troubling possibility of Shia plans to replace an iron-fisted minority with the tyranny of the majority. That was the main reason behind the Kurdish parties' insistence on a power-sharing system that would recognize Kurdistan as one geographic and political entity and prevent future discrimination by the central state apparatus.

\section{Democracy and Power-Sharing in Iraq: Towards an Alternative Model}

The issues of hydrocarbons legislation, disputed territories and federalism clearly pitch the KRG and the Iraqi government against each other. Nevertheless, rather than a disintegrating factor, this situation needs to be understood in the context of the ethnosectarian political dynamic, which implicitly denounces Kurdistan as an ethnic entity. Despite shared anti-Maliki sentiments with many other Iraqi Arab groups, the Kurdistan

${ }^{171}$ Al-Rikabi, Ramsey. "The Kurds and the Constitution,” Al-Ahram Weekly, March 18, 2004. 
region has no significant support from other Iraqi populations for its key demands regarding the implementation of the constitution because of the still-powerful ethnic fault lines in Iraqi society. As the borders of the Kurdistan region are perceived to be ethnically defined, the disputes over autonomy, management of oil resources, and the status of Kirkuk and other oil-rich areas continue to derail the post-Saddam democratization process in the country.

It is true that Kurdistan certainly pertains to the homeland of the Kurds as a distinct ethnic group. In that sense, the Kurdishness of Kurdistan is undeniable. However, the Kurdistan region is not ethnically homogeneous and some of the other governorates of Iraq, most notably Baghdad, Nineveh, Diyala and Kirkuk, have highly heterogeneous populations. The 2005 constitution provides a legal framework to define federal sub-units that transcend ethnic boundaries and focus on regional identity, with varying degrees of ethnic and religious homogeneity and heterogeneity. ${ }^{172}$ Article 117 of the constitution recognizes Kurdistan as one of the federal regions and according to article 124, the Baghdad, with its administrative borders, constitutes the governorate of Baghdad and may not merge with a region. Regulations regarding the formation of new regions are specified in article 119, which states that the remaining governorates shall have the right to organize into a region based on a request to be voted on in a referendum. The constitution, thus, allows the Iraqis themselves rather than the political elites to determine the nature of their federation and whether it will be defined by ethnicity or regional

\footnotetext{
${ }^{172}$ Article 113 of the constitution recognizes the Kurdistan Region as one of the sub-units of the federation. According to article 120, the Baghdad governorate constitutes its own region. According to article 115, each of the remaining fourteen of the country's eighteen governorates has the right either to form its own region, to join with others to form a larger region, or to maintain its status as a governorate. Full text is accessible at http://www.washingtonpost.com/wp-dyn/content/article/2005/10/12/AR2005101201450.html
} 
identity. From this perspective, Iraq has a chance to evolve naturally into a hybrid ethnic/territorial federation that will both ensure the dominant ethnic and religious populations their rights will not be compromised, and provide political consensus that regional administrations will be based on respect for diversity.

Iraq's dilemma is that an ethnic federation in which the political parties, electoral politics and power in the central government are organized around ethnic groups would most likely exacerbate, rather than alleviate, the ethno-sectarian nature of politics in the country. A territorial federation, on the other hand, which deliberately draws lines to divide ethnic concentrations would equally reinforce the ethnic divisions, at least in the short term, given the fact ethnicity is already one of the powerful defining features of Iraq's political life. What the advocates of territorial federalism fail to realize is that territorial federalism offers benefits once the system is already in place, but it does not provide a solution to the dilemmas of creating territorial federalism in deeply-divided societies composed of geographically concentrated ethnic groups in the first place. Currently, any attempt to divide Kurdistan territorially would certainly be forcibly resisted by the Kurds and might spark violent reactions that would unravel the fragile political consensus underpinning Iraq's nascent political order. Hence, what Iraq needs is a more fluid option that would prevent the imposition of either of these two extremes, and instead enable a smooth transition from ethno-sectarian politics to pluralist democracy.

The option of regional federalism, where the sub-units will be defined not by ethnicity but on the basis of distinct historical and cultural identities, has the potential to offer a viable solution to the controversies regarding the design of Iraq's federal 
system. ${ }^{173}$ Under this model, in terms of population, the regional sub-units will still be dominated by certain ethnic or religious groups, but communal identities will not be their defining feature. Since the late 1990s, the Kurdish political leadership of Iraq has attempted to build a civic nationalist project that promotes the idea of a "Kurdistani" identity to which Arabs, Turkmens, Assyrians as well as the Kurds living in Kurdistan region could subscribe. In doing so, the Kurdish leaders have sought to promote the idea that the "Kurdistan Region" is a geographic construct and an institutionalized entity based on the recognition of the distinct ethnic and cultural identities of its component peoples under an all-encompassing "Kurdistani" vision.

Although it has yet to be voted on in a referendum and thereby enter into force, the KRG approved the draft constitution of the Kurdistan region on June 24, 2009, which lodges significant protections for the non-Kurdish groups in the region. The equality clause of article 20 lays the groundwork for this by stating that all forms of discrimination on the basis of race, color, sex, language, social background, nationality, origin, religion, belief, thought, age, social, political or economic status, or handicap are prohibited. ${ }^{174}$ Article 5 of the draft constitution recognizes the ethnically and religiously diverse structure of Kurdistan by stating that the people of the region are composed of Kurds, Arabs, Chaldo-Assyrian-Syriacs, Armenians and others who are citizens of Kurdistan. The religious rights of the Christians, Yazidis and other non-Muslim groups are recognized under article 6. The draft constitution accepts Kurdish and Arabic as the

\footnotetext{
${ }^{173}$ Anderson, Liam (2008). 251-255.

174 The full text of the draft constitution of Kurdistan Region - Iraq is accessible at http://gulfanalysis.files.wordpress.com/2013/12/kurdistan-draft-constitution-2009.doc.
} 
two official languages of the Kurdistan region, but also guarantees the right of the region's citizens to educate their children in their mother tongue and recognizes that along with Kurdish and Arabic, Turkmen and Assyrian shall be official languages in administrative districts populated by the speakers of these languages.

The draft constitution as well as the electoral law of the Iraqi Kurdistan National Assembly recognizes the election system shall take into consideration the fair representation of all geographic localities, ethnic and religious groups and that a member of the parliament shall represent all the groups that make up the people of Iraqi Kurdistan, regardless of their political, ethnic and religious affiliation. According to article 22 of the electoral law, every group or ethnic minority (Turkmen, Arab or others) have the right to forward its own roster that includes the names of their nominees for the Iraqi Kurdistan region. ${ }^{175}$

Although they gained some support from Turkmens and Assyrians, it is hard to claim the Iraqi Kurdish leaders have succeeded in their efforts to promote a regional vision of Kurdistan as home to diverse identity groups living in the north of the country. The overwhelming sentiment among the Assyrian community is to preserve their distinctiveness rather than subscribing to the wider "Kurdistani" identity, which is still considered as representing the dominance of the Kurds in the region. ${ }^{176}$ The strategy to gain Turkmens' support for the Kurdistani initiative also failed due to the problems

\footnotetext{
175 The UNAMI translation of the Electoral Law of the Iraqi Kurdistan National Assembly (KNA). http://unami.unmissions.org/LinkClick.aspx?fileticket=ZTDKqBiClCo\%3D\&tabid=4300\&language=enUS

176 Stansfield, Gareth, Ahmadzadeh, Hashem (2008). "Kurdish or Kurdistanis? Conceptualizing Regionalism in the North of Iraq" in An Iraq of Its Regions: Cornerstones of a Federal Democracy edited by Reidar Visser, Gareth Stansfield, New York: Columbia University Press, 136-140.
} 
created between the communities by the situation in Kirkuk. The KRG's demand for the inclusion of Kirkuk into the Kurdistan region of Iraq, and the insistence on its Kurdish origins has put the Kurds in conflict with the Turkmens who accused the Kurdish leadership of attempting to "Kurdify" Kirkuk just as Saddam "Arabized" it. ${ }^{177}$ Similar to Arabs, for the Turkmens, both inside and outside of Kirkuk, incorporation of Kirkuk into the Kurdistan region would accelerate Kurdish independence and, thus, Iraq's breakup. $^{178}$

The policy of promoting the notion of "being Kurdistani" has failed for two reasons. The first reason is the continued dominance of ethno-sectarian divisions in defining Iraqi political life and the accompanying political pressures that exist in the country, particularly over the controversial issues of federalism and disputed territories. Latent suspicion continues to exist between Kurds, Arabs, Assyrians and Turkmens. The second reason is the fact that the traditional understanding of Kurdistan, that is the idea of a greater Kurdistan entity as the homeland of all Kurds, grew stronger among the Iraqi Kurds mainly due to the heightened expectations following the survival of Kurdistan region in Iraq since 1991. The consolidation of this idea has happened perhaps even against the wishes of the leaderships KDP and PUK, who now face the challenging task of balancing the political realities of post-Saddam Iraq with the expectations of the Kurds in the north.

The reluctance of the Turkmen and Assyrian communities to accept the wider "Kurdistani" identity, as well as the growing Kurdish nationalist sentiment in the north,

\footnotetext{
${ }^{177}$ Ibid. 145.

${ }^{178}$ International Crisis Group (2011). 7.
} 
suggests the attempts to distance the Kurdistan region from being viewed to be overtly Kurdish will remain futile. However, the Kurdish politicians are keen to continue to follow this strategy. Why this is the case is not difficult to comprehend: Kurdish leaders are fully aware of the fact their geography and power bases are strongly against them in case they opt for independence. The option of independence also means military confrontation not only with Iraq but also with the neighboring states and a possible US involvement. It is hard to imagine the Iraqi Kurdish leaders would sacrifice the economic and political gains as well as the international legitimacy they have worked so hard to achieve since the establishment of the KRG in 1991 to throw themselves into another wave of violence. Under these circumstances, the Kurdish leadership has followed the strategy of gradually changing the image of Kurdistan, perceived as an ethno-nationalist movement, which works against the KRG's relationship with both the Iraqi government and the regional powers.

Concerning the debate on federalism and democracy, the problem facing Iraq is not the domination of federal regions by certain ethnic or religious groups, as the advocates of territorial federalism argue. The problem is the possibility that ethnicity or religion would be the defining feature of the federal sub-units. In other words, there is a crucial difference between a federal region in which majority of the population identifies itself by a certain ethnic or religious identity, and a federal region in which local authorities govern according to ethnic or religious loyalties. Because Iraqi politics is still defined in terms of communal divisions, it is assumed that regional ethnic and religious demographics would automatically reflect on governance. Rather than the ethnic versus territorial federalism dichotomy, the debate on federalism and democracy in Iraq should 
focus on two main issues: whether local governments act responsibly toward all their citizens within their areas, and not just for ethnic or sectarian co-nationals, and how to reach a broadly-accepted accommodation over the role of the central government.

Within this framework, the efforts of the Kurdish leaders to establish a pluralist local government that recognizes the ethnic and religious diversity of Kurdistan is very important in terms of the implementation of regional model of federalism. The same model is applicable to southern Iraq as well, where two non-sectarian ideological currents have historically been far more important than the idea of Shia consolidation in a territorial bloc: the "far south" which is composed of the triangle of Basra, Nasiriyya and Amara, and the "Middle Euphrates" which represents the regionalism of the urban centers and the tribes. ${ }^{179}$ Similar to Kurdistan, both of these sub-units will be dominated by Shia Arabs in terms of population, but, critically, the Arab ethnicity or the Shia religious identity will not be their defining feature. In this way, the proposed regional model will both ensure a sense of security among Iraq's major identity groups by avoiding risky attempts at dividing up the geographic concentrations of ethnicities, but also alleviate the impact of ethno-sectarian divisions on politics by encouraging the expression of regional diversity on a non-communal basis.

Even if the Kurdish leaders' efforts to promote a civic model of nationalism in Kurdistan can be viewed as part the strategic objectives of the KRG, promotion of pluralism and the legal recognition of the multi-ethnic and multi-cultural structure of Kurdistan is itself very significant. This approach may set a useful example for the rest of

\footnotetext{
${ }^{179}$ Visser, Reidar (2008). "Two Regions of Southern Iraq," in An Iraq of Its Regions: Cornerstones of a Federal Democracy edited by Reidar Visser, Gareth Stansfield, New York: Columbia University Press, 29.
} 
Iraq and play a crucial role in resolving many controversial issues regarding federalism. For example, rather than viewing Kirkuk as an intractable problem, predetermined by its contentious history and current politics, the Iraqi leaders may approach Kirkuk as an opportunity to build a compromise around legally entrenched governing arrangements which involve power-sharing mechanisms based on the promotion of local "Kirkuki" identity alongside the region's component peoples - Kurds, Arabs and Turkmen.

\section{The Road Ahead}

Iraq's history is filled with instances of discrimination and violence against certain sections of society on the basis of ethnicity, including attempts at genocide. For this reason, any attempt at imposing a solution on Iraq that does not take past communal traumas into consideration risks violent reaction, which, in turn, would threaten the very territorial integrity of the country. The model of a strong centralized government with a powerful controller was tried in Iraq and went horribly wrong, as was witnessed during Saddam Hussein's regime. However, federalism has barely been given time to take root. Since the 2005 parliamentary elections, what is seen in Iraq has only been a half-hearted attempt at decentralization, which resulted in a dysfunctional democracy. The idea of true federalism is still regarded with suspicion in Iraq because of the popular assumption that a federal Iraq means empowerment of communal loyalties, thus, a weaker Iraq. In this regard, the management of the Kurdish-Arab divide is central to Iraq's successful transition to a stable federal democracy.

Opting for independence is a decision that lies with the Kurdish people and their political representatives. Given the regional political dynamics, this option, at least for now, is quite unlikely. The reality on the ground, on the other hand, strongly indicates 
that an Iraq without Kurdistan has a significantly lower chance of becoming a true democracy than an Iraq where Kurdistan is an integral part of Iraq within a federal framework. The role of the KRG is critical in Iraqi politics in terms of the consolidation of power-sharing mechanisms as the Kurdish movement is the only organized actor in the country who has the capacity to act as a pressure group and force the central government to negotiate regarding on decentralization and the creation of a more inclusive political framework in Iraq. Without Kurdistan, it is quite likely Iraq could slide back to a strong centralized state built around a distinctly Arab narrative with possible sporadic outbreaks of sectarian conflict and the use of coercion to maintain unity and stability. 


\section{CHAPTER IV}

\section{KURDS IN TURKEY}

A great responsibility falls on all of us to create an equal, free and democratic country of all peoples and cultures, befitting the history of Kurdistan and Anatolia. On this occasion of Newroz, I call on the Armenians, Turkomans, Assyrians, Arabs and all other peoples just as much as on the Kurds to behold the flame of freedom and equality - the fire that is lit here today - and embrace it as their own. ${ }^{180}$

Abdullah Öcalan, the imprisoned leader of the Kurdistan Workers' Party (PKK), made a call, described by many political analysts as "historic," on March 21, 2013, the Kurdish new year (Newroz). Obtained by the leader of the pro-Kurdish Peace and Democracy Party (BDP) during his visit to Öcalan's prison cell, the statement was the result of meetings held by Öcalan with the Turkish government since October 2012. The statement was broadly viewed as a declaration of a ceasefire and an end to the conflict that has riven Turkey for the past three decades.

The struggle of the Kurds in Turkey did not start with the PKK, which was formally founded in 1978 and launched its first attack in Turkey in August 1984. Nor was the statement of March 2013, the PKK's first ceasefire declaration. However, Öcalan's letter from jail marked the beginning of a new era for the Kurdish question in Turkey for a number of reasons. First, compared with the majority of other Kurdish parties in Kurdistan, the PKK is a relatively recent actor in the broader Kurdish struggle in the Middle East. It has become one of the most influential actors in the region since the early 1990s by mobilizing the Kurdish masses not only in Turkey, but also in Iran, Iraq and

180 “Öcalan's Historic Newroz 2013 Statement," March 24, 2013. Available at http://peaceinkurdistancampaign.wordpress.com/2013/03/24/Öcalans-historic-newroz-2013-statement/ (Accessed January 8, 2014). 
Syria. Secret talks between the Turkish government and Öcalan took place several times in the 1990s and 2000s, but they were never made public because of the classification of the PKK as a terrorist organization. Furthermore, those negotiations largely reflected the Turkish government's prime motive to end the armed insurgency of the PKK rather than a genuine will to establish peace in Turkey. In this context, the March 2013 declaration was viewed as "historic" by many given it was the first time Öcalan was publicly acknowledged by the Turkish government not only as a legitimate political actor representing the Kurds in Turkey, but as a chief negotiator within the peace process.

Second, since 1993, the PKK had declared numerous unilateral ceasefires with the stated intention of opening peace negotiations. In most cases, these initiatives were ignored by successive governments and portrayed instead a sign of the PKK's weakness and imminent defeat. It is important to note that although the March 2013 statement was largely interpreted by the international media as a ceasefire declaration, Öcalan's letter in fact did not even once include the words "ceasefire" or "truce." The most appropriate definition would be "a call for the cessation of hostilities," but Öcalan's assessment and appeal was far ahead of even that. ${ }^{181}$ Öcalan's main purpose was to move the Kurdish struggle from the military realm to the world of democratic politics in Turkey. Silencing the guns, which implies "cease-fire," was an inseparable component of this process, but only as a logical starting point to pave the way for achieving the broader goal of establishing a democratic Turkey not only for the Kurds, but for all peoples and cultures.

The founding manifesto of the PKK, which was published in 1978, sets the party's goal as the establishment of an independent, united and democratic Kurdistan and

\footnotetext{
${ }^{181}$ Çandar, Cengiz. “Öcalan’s Message Is Much More Than a Cease-fire,” AlMonitor, March 24, 2013.
} 
states that other forms of solutions such as autonomy or federalism are "reformist," and consequently "reactionary" views for they do not tend to disturb the existing state borders. ${ }^{182}$ The manifesto stresses the indispensability of the use of force against the "colonial" forces ${ }^{183}$ and embraces that all-in-one use of ideological, political, and military forms of struggle are necessary for the success of the national liberation of Kurdistan. It emphasizes that the PKK's primary focus is on the Kurdish struggle in Turkey, but that national liberation will be achieved through the destruction of not only Turkish colonialism, but also the colonialism of the other occupying state-forces in Kurdistan and the subsequent construction of a democratic and united Kurdish state.

Until the early 1990s, independent statehood, armed struggle and the idea of united and democratic Kurdistan were the three major pillars of the PKK movement. The Newroz message of Öcalan, which strongly emphasized ending the armed struggle and finding a solution to the Kurdish question within the democratic politics of Turkey, remarkably reflects the dramatic alterations in the PKK's political and ideological outlook on the Kurdish question as it gradually unfolded over two decades. Throughout this process, the major changes the PKK underwent with regard to its programmatic development can be categorized into three areas: an ideological transformation from state-seeking nationalism to one centered on "radical democracy," which is based on the rejection of the concept of nation-state; the political transformation from the ideal of

\footnotetext{
182 Öcalan, Abdullah (1978). Kürdistan Devriminin Yolu (The Path to Kurdistan Revolution) (Manifesto), Weşanên Serxwebun, Köln.

183 The founding manifesto of the PKK defines Kurdistan as a "colony" and the Kurdish question as a problem of colonization. Accordingly, Turkey, Iran, Iraq and Syria are defined in the manifesto as "colonial forces.
} 
separate statehood to the ideal of democratic confederalism, which represents a new specification of Kurdish independence; and strategic transformation from armed struggle to political struggle aimed at negotiation and peaceful settlement.

The evolution of the PKK shows how Turkey's Kurdish question has been translated into a quest for democracy that concerns all peoples living within the borders of Turkey. "Radical democracy" is a term that thoroughly captures the emergent discourse of the PKK in the 1990s, given that it provides a new understanding of politics in Turkey on the basis of a critique of the nation state. This approach differentiates the Kurdish movement in Turkey from its counterparts in Iran, Iraq, and Syria, as it views the nation state as the main obstacle to the liberation of people, be they Kurdish or other. While the Kurdish movements in Iran, Iraq and Syria are equally critical of the nation state and its implications for democracy, their criticisms concentrate solely on the exclusionary character of Arab and Shia Islamist Iranian nationalisms. The discourse of the PKK, on the other hand, derives from a critical evaluation of the theoretical foundations of the concept of nation state and underscores its antagonistic relationship with democracy. Accordingly, the establishment of an independent Kurdish state in the context of the PKK's discourse would only further consolidate the existing system of nation states in the Middle East, which are seen by the PKK as the main obstacles to democratization in the region throughout the twentieth century. The solution, therefore, lies in transforming the existing system, not in consolidating it.

\section{The Ideological Foundations of the Kurdish Movement in Turkey}

It is not possible to understand the evolution of the Kurdish movement in Turkey from the 1990s onwards without comprehending its relationship with the Turkish left, 
which provided the Kurds with an important avenue to express their grievances throughout the 1960s and 1970s. The Kurdish movements in the Middle East came into close contact with the leftist movements in all parts of Kurdistan throughout the twentieth century. This association sometimes took place sometimes through the politicized Kurds' tendency to view the communist parties as the best places for the expression of their militancy in the absence of Kurdish nationalist parties, as in Syria, and sometimes through the reliance of Kurdish parties on leftist forces to maintain their presence under suppressive political conditions, as in Iran. In Iraq, where Kurdish parties managed to maintain a strong presence in the political arena despite suppression, the left-wing forces saw the Kurds as critical allies in their struggle against their political rivals. However, it is only in Turkey that the organized, mass-based Kurdish movement was born directly from the leftist movement with an equally strong emphasis placed on both socialist and Kurdish nationalist goals. The alliance between the Kurds and the Turkish left resulted in separation mainly because of the failure of leftist forces to accommodate ethnic demands. Nevertheless, once again, only in Turkey, this process of dissociation resulted in major political and ideological transformations within the Kurdish movement.

The 1960s is usually considered as "rebirth" or "reawakening" of Kurdish nationalism in Turkey ${ }^{184}$ after the Kurdish revolts of 1920s and 1930s in the early years of the Republic. Although it is not entirely wrong to use the term "reawakening" to describe Kurdish nationalism during this period, it is important to note the underlying

\footnotetext{
${ }^{184}$ White, Paul (2000). Primitive Rebels or Revolutionary Modernizers? The Kurdish National Movement in Turkey, London: Zen Books, 130; McDowall (1996). 404-417.
} 
causes of Kurdish activism and show that the element of "Kurdishness" as defined in the 1960s and 1970s differs greatly from the 1920s and 1930s.

The view that the Turkish state's discriminatory, violent and exclusive policies have had a decisive influence in shaping contemporary Kurdish nationalism has substantial explanatory power in accounting for the emergence of political mobilization among the Kurds after the First World War. The most significant result of WWI in terms of its repercussions on the future trajectory of Turkish nationalism was the replacement of the decentralized multi-ethnic Ottoman heritage with a centralized nation-state, defined as the Kemalist model, which does not recognize any nation other than the Turks. ${ }^{185}$ The problem of "minorities" was solved in the Turkish constitutional scheme without ever addressing it ${ }^{186}$ and all the "now-citizens" of the Turkish Republic were invited to become Turks through article 88 of the 1924 Constitution, which states, "Everyone bound to the Turkish State through the bond of citizenship is a Turk."

The shift from the multi-ethnic, multi-cultural realities of Ottoman Empire to the nation-state model was considerably problematic from the standpoint of the Kurds not only because of the loss of regional autonomy they had under the decentralized Ottoman system, but also because the new state denied the ethnic heterogeneity of society in legal terms. The growing Kurdish discontent following the foundation of the Republic was shaped by both the concerns of the traditional Kurdish elites over the loss of their

\footnotetext{
${ }^{185}$ Yeğen, Mesut (2007). "Turkish Nationalism and the Kurdish Question," Ethnic and Racial Studies, 30 (1): $125-126$.

${ }^{186}$ There is no reference in the Constitution to the word "minority". The status of minorities in Turkey was established by the 1923 Treaty of Lausanne, which defines minorities on the basis of religion. Accordingly, the Lausanne Treaty envisions full citizenship rights for non-Muslims, yet falls short of extending legal protection to Turkey's numerous ethnic, linguistic and cultural minorities because of its restrictive definition.
} 
privileges under the Ottoman rule, and an increasing emphasis on "Kurdishness" as an ethno-political cause.

Since the concept of nation was defined within an essentially Islamic framework under the Ottoman Empire, although aware of their ethnic identity, the Kurdish traditional dignitaries and the Kurdish intelligentsia did not conceive "Kurdishness" as a decisive element in determining their social and "national" status. ${ }^{187}$ It would be misleading to exaggerate the nationalist essence of the revolts of the 1920 s and 1930 s as they did not take place around a clear Kurdish nationalist agenda. However, it is important to note that the logic of the nation-state embraced by the new Republic played a significant role in increasing the emphasis of the Kurds on "Kurdishness" as their primary identity marker. These growing ethnic sentiments in the early years of the Republic provided the social, cultural and political resources for later Kurdish nationformation in Turkey.

Within this framework, rather than a period of "reawakening," it is more appropriate to view the 1960 s and 1970 s as a period of maturity of the Kurdish nationalist consciousness in Turkey. Kurdish activism for the first time appeared in Turkey's political arena as an organized movement with a specific structure, program and strategy. It was no longer possible to reduce political mobilization among Kurds to a reaction to ethnic Turkish nationalism and discriminatory state policies. By the 1960s, a young generation of Kurdish counter elites seized control of the movement from traditional Kurdish leaders, defined Kurds in radical new ways, and engaged in new types of

${ }^{187}$ Bozarslan, Hamit (2003). "Kurdish Nationalism in Turkey: From Tacit Contract to Rebellion (19191925)" in Essays on the Origins of Kurdish Nationalism edited by Abbas Vali, Costa Mesa, CA: Mazda Publishers, 170. 
political activism with clearly defined nationalist goals aimed at challenging the basic principles of the republican state. ${ }^{188}$ This new generation was composed mostly of educated intelligentsia using legal, non-violent repertoire to promote a class-based interpretation of the Kurdish question with the goal of creating a socialist state. While earlier generations of Kurdish activism failed to create mass action due to tribal, religious and sectarian divides, this new generation not only brought diverse Kurds together in protest, but did so across ethnic boundaries in coordination with the Turkish left. ${ }^{189}$

The 1940s and 1950s were largely experienced as "decades of silence"190 for the Kurds in Turkey given the Turkish state's policy of denying the very existence of ethnic communities other than Turks, and the militarization and systematic surveillance of Kurdish territories from the 1930s, which had an intimidating effect on the population. By the 1960s, the "decades of silence" ended when Kurdish unrest resumed as a segment of the rising left-wing opposition in Turkey. A broad stratum of educated Kurds, who were mostly university students, discovered in leftist ideas - more specifically, in Marxism-Leninism - a universalistic syntax that allowed them to establish a link between the "oppressed Kurdish nation" and "oppressed classes" of Turkey. ${ }^{191}$ In this regard, they

\footnotetext{
${ }^{188}$ Watts, Nicole F (2007). "Silence and Voice: Turkish Policies and Kurdish resistance in the mid-20 Century" in The Evolution of Kurdish Nationalism edited by Mohammed M. A. Ahmed and Michael Gunter, Costa Mesa, CA: Mazda Publishers, 53-54.

${ }^{189}$ Ibid. 54.

${ }^{190}$ See Nezan, Kendal (1993). "Kurdistan in Turkey," in A People Without A Country: The Kurds \& Kurdistan edited by Gerard Chailand, New York: Olive Branch Press, 62-68; Bozarslan, Hamit, "Kurdish Historiographic Discourse in Turkey," in Essays on the Origins of Kurdish Nationalism edited by Abbas Vali, Costa Mesa: Mazda Publishers, 31-34.

${ }^{191}$ Bozarslan, Hamit (2007). "Kurdish Nationalism Under the Kemalist Republic: Some Hypotheses," " in The Evolution of Kurdish Nationalism edited by Mohammed M. A. Ahmed and Michael Gunter, Costa Mesa, CA: Mazda Publishers, 50.
} 
began to appropriate a socialist discourse stressing national oppression and economic exploitation of the Kurdish peasant masses, which gradually culminated in the conception of Kurdistan as a "colony" and Kurds as a colonized people. ${ }^{192}$ This framing of the Kurdish issue gained widespread acceptance among Kurdish activists, yet laid the groundwork for the organizational and ideological separation of the Kurdish struggle from the struggle of the revolutionary left in Turkey in the 1970s.

Until 1968, the Workers Party of Turkey (TIP) played a major role in organizing and leading the socialist struggle in Turkey and served as an incubator for Kurdish mobilization by incorporating many Kurdish activists into the Turkish political system. TIP drew attention to both the problem of economic underdevelopment in the Kurdish inhabited regions of Turkey and the political and cultural problems encountered by the Kurds due to state discrimination. The party played a particularly important role in organizing the 1967 "Eastern Meetings," which were a series of protest meetings and demonstrations held in several towns in Turkey's mainly Kurdish southeast. Framed as a protest campaign against economic underdevelopment and lack of democracy, they constituted the first peaceful mass Kurdish protests in republican history and significantly contributed to the public debate on the Kurdish question and demands of the Kurdish people. ${ }^{193}$ The fact that the Kurdish rights agenda was adopted not only by the Kurdish socialists, but also by the Turkish leftists, led to the integration of Kurdish resistance as a political practice at the heart of Turkish politics. This came as a major challenge to the

\footnotetext{
${ }^{192}$ Günes, Cengiz (2007), “Kurdish Politics in Turkey: A Question of Identity," The International Journal of Kurdish Studies, 21 (1/2): 17.

${ }^{193}$ Watts (2010). 41.
} 
Kemalist project, which was mainly based upon isolating the Kurdish resistance in geographical and ideological terms. ${ }^{194}$

The interpenetration of Kurdish and Turkish politics proved remarkably durable until the late 1960s. However, the signs of splintering of the Turkish socialist and Kurdish political agendas began to appear when, as elsewhere in the world, the left in Turkey started to become severely handicapped by divisions and internal struggles in the 1970s. Very basically, two main currents of thought and action in the revolutionary left emerged. "Socialist revolutionaries" claimed capitalism had advanced in Turkey, and a transition to socialism was possible. "National democratic revolutionaries," on the other hand, envisaged a two-phase revolution, the first phase being the national democratic revolution and the second being socialist revolution. This theorization characterized Turkey as a semi-colony of Western imperialism and concluded that, for Turkey to have its economic and political independence, workers, peasants and progressive forces within the bourgeoisie needed to enter into an alliance to achieve a national democratic revolution, which would be followed by a socialist revolution. ${ }^{195}$

TIP was the main representative of the socialist revolution thesis. It was also the first legal political party to openly acknowledge the existence of the Kurdish people in Turkey and draw attention to their national oppression under the republican rule. However, the factional struggles and disagreements over the revolutionary strategy gradually plunged the party into crisis and marginalized its position within the leftist

\footnotetext{
${ }^{194}$ Watts (2007). 77.

195 Jongerden, Joost, Akkaya, A. Hamdi (2012). "The Kurdistan Workers Party and a New Left in Turkey: Analysis of the Revolutionary Movement in Turkey through the PKK's Memorial Text on Haki Karer," European Journal of Turkish Studies, 14: 4.
} 
movement in the late 1960s. In the meantime, as the national democratic revolution thesis became more dominant in the Turkish socialist movement in the early 1970s, the relationship between the Kurdish activists and the Turkish left wing began to unravel.

After the military coup of March 1971 was a period of collapse for the left in Turkey given the ban on left wing organizations and publications, the arrest of its militants and the killing of its main leaders. It was during this period that the idea of organizing a separate Kurdish struggle around the thesis of Kurdistan as a "colony" was born. As the left started to organize again in the mid-1970s, the division between the Turkish socialists and Kurdish activists increasingly came to the surface. Turkish leftists were exposed to criticism by the Kurdish groups on the grounds they had left their challenging position and had become parties of the regime. The national democratic revolution thesis' definition of the Turkish state as a semi-colony of Western imperialism inevitably led to a tendency on the part of the left to reconcile the revolutionary movement with the Kemalist ideology. ${ }^{196}$ The motto "Fully Independent Turkey" became one of the most widely used slogans by the left in the 1970s. By defining Turkey's status as a semi-colony, this approach turned a blind eye to Turkey's own role as a colonizing force vis-à-vis Kurdistan. According to the Kurds, the Turkish left not only became statist and lost its capacity to act as a genuine opposition force in Turkey, but it also failed to approach the Kurdish question from an emancipatory perspective.

Turkish socialists remained generally unreceptive to Kurdish rights and demands because they perceived the ethnic and national demands as a threat to the unity of the

${ }^{196}$ Hevra: Devrimci Türkiye Kürtleri Örgütü (Organization of Revolutionary Turkish Kurds) (1974). Türkiye Şartlarına Ters Düssen Bir Tez: Milli Demokratik Devrim (A Thesis that Runs Counter to the Conditions in Turkey: National Democratic Revolution), Zurich: Ronahi Yayınları. 
socialist movement and the working class in Turkey. ${ }^{197}$ In addition, increasing government repression and paramilitary activity against the Kurds in southeast Turkey in the late 1960s and 1970s, gradually increased the gap between the socialist agenda and the Kurdish rights agenda because of the growing "separatist" stigma attached to the Kurdish movement. In this context, the Turkish socialists increasingly viewed the Kurdish question as a problem only to be considered once a socialist Turkey was established. The Kurdish movement, on the other hand, differentiated itself from the Turkish left by reframing the socialist ideology in the context of the national question and portraying the national liberation of the "peoples" as a core requirement of the revolutionary and socialist ideology. This approach increasingly manifested itself in the Kurdish activists' emphasis on the distinction between the nationalism of the "oppressed nations" and that of the "oppressor nations," and the promotion of the idea that unless the reality of Kurdistan was recognized in Turkey, it would be impossible to pursue and implement a truly socialist ideology.

The rise of the Turkish left and the emerging schisms within the Turkish ruling elite in early 1960s are often referred to as important political opportunity structures that enabled the Kurdish movement to reassert its influence in Turkey's political arena. The Turkish left's real impact on Kurdish politics in Turkey lies in the way it helped construct Kurdish identity by providing Kurdish nationalism with an ideological framework through which the Kurdish activists found collective answers to questions about "who they are" and "what kind of world they want to live in." Nevertheless, the developments from the late 1960s on showed that the Kurdish groups, despite the still relatively

${ }^{197}$ Güneş (2012). 61. 
influential position of the Turkish left, decided to pursue a separate agenda shaped by a reinterpretation of socialist ideology on the basis of Kurdish national struggle. This was certainly not a politically pragmatic move for the Kurds because of the high costs of pursuing identity politics in Turkey at a time when just being a leftist was a dangerous path to follow. The Kurds, however, were determined to take up this challenge given the growing power of Kurdish nationalism as an ideological force in its own right. Kurdish national demands were no longer up for compromise, however costly the pursuit of their realization might be.

\section{Enter the PKK}

Although the signs of separation between the Turkish left and Kurdish nationalism became clear in the late 1960s, Kurdish activism was already evolving towards a more organized form. The Kurdish uprising led by Mullah Mustafa Barzani in 1961 had a direct bearing on this process. In 1965, the Kurdistan Democratic Party of Turkey (TKDP) was established as the ideological equivalent of Mustafa Barzani's KDP in Iraq. TKDP advocated for a similar autonomist plan and demanded the recognition of social, political and cultural rights of the Kurds within the territorial integrity of Turkey. TKDP was the first specifically Kurdish party of Turkey, but it never managed to have a strong hold among the Kurds because of its very conservative ideology. The founders of the party, Faik Bucak and Sait Elçi, had previously subscribed to the mainstream rightist Turkish politics. Consequently, they appealed to a conservative society, one that is loyal to the aghas and tribal structures organically tied to the government for the protection of their interests. Given its ideological link with the existing political system, TKDP had little to offer. Many of the party's leaders were arrested in January 1968, and internal 
divisions in 1969 further weakened the party. ${ }^{198}$ The party revived briefly during the second half of the 1970s, but failed to put down strong roots.

On the leftist front, as the factional infighting within TIP made clear the fact it was unable to formulate and maintain a coherent policy on the Kurdish issue, the discontented Kurds intensified their attempts to establish Kurdish socialist organizations which resulted in the establishment of Revolutionary Eastern Cultural Hearths (DDKO) in 1969. DDKO brought together university students and youth in Turkey's urban centers who shared common goals revolving around the recognition of the political, social and economic rights of the Kurds, developing Kurdish culture and language, and combatting the official policies of the Turkish state that deny the existence of the Kurds in Turkey. ${ }^{199}$ The DDKO, like TIP and other leftist organizations, was closed following the 1971 coup. They were reorganized in mid-1974 as the Revolutionary Eastern Cultural Associations (DDKD) and remained one of the most important organizations among the left wing Kurdish nationalist groups in the 1970s.

The main legacy of the DDKO is that they represent the first attempts on the part of the Kurdish activists to break away from Turkish socialists and form autonomous Kurdish organizations on the basis of the discourse of "national oppression" of the Kurds. Throughout the 1970s, the number of legal and underground left-wing Kurdish organizations proliferated rapidly. Some of these groups such as the Rizgari (Liberation) movement and its break away, Ala Rizgari, traced their origins to the DDKO. Another

\footnotetext{
${ }^{198}$ Epözdemir, Şakir (2005). Türkiye Kürdistan Demokrat Partisi: 1968/235 Antalya Davası Savunması (Kurdistan Democratic Party of Turkey: 1968/235 Antalya Lawsuit Defense), Istanbul: Peri Yayınlar1.

${ }^{199}$ Kısacık, Raşit (2011), Kürt Sorunu ve Etnik Örgütlenmeler - 2: Rizgari ve Ala Rizgari (Kurdish Problem and Ethnic Organizations - 2: Rizgari and Ala Rizgari), Istanbul, Ozan Yayınc1lı, 39-40.
} 
group, the Turkish Kurdistan Socialist Party (TKSP), was established by the TIP's Kurdish members and became one of strongest Kurdish socialist groups in the 1970s. The popularity of socialist ideas among the Kurdish activists also affected the ideological evolution of the formerly conservative TKDP. The defeat that the Iraqi Kurdish movement suffered in 1975 played a significant role in discrediting the conservative autonomist brand of Kurdish nationalism represented by the TKDP in Turkey. TKDP began its revival in 1975 and its left wing dominated the DDKD. Later, three groups, Kawa, the KIP/DDKD and the KUK (National Liberationists of Kurdistan) emerged from the DDKD movement and became influential in Kurdish politics throughout the second half of the 1970s. Finally, there was the PKK (Kurdistan Workers Party), which had its roots in the illegal revolutionary left in Turkey. ${ }^{200}$

The 1970s witnessed a virtual explosion of Kurdish nationalist organizations in Turkey. However, none of these groups were able to survive the effects of the 1980 military coup, which targeted the political left, both Turkish and Kurdish variants, in an attempt to eradicate it. ${ }^{201}$ According to İsmet İmset, there were twelve Marxist-Leninist Kurdish groups active in the 1970s, among which only the PKK (Kurdistan Workers Party) managed to achieve a steady rise and growing effectiveness throughout the 1980 s and $1990 \mathrm{~s}^{202}$ The endurance of the PKK movement in the post-1980 period is a

\footnotetext{
${ }^{200}$ Jongerden, Joost, Akkaya, A. H. (2011). "Born From the Left: The Making of the PKK," in Nationalism and Politics in Turkey: Political Islam, Kemalism and the Kurdish issue edited by Marlies Casier and Joost Jongerden, London and New York: Routledge, 125.

${ }^{201}$ Barkey, Henri (1996). "Under the Gun: Turkish Foreign Policy and the Kurdish Question," in The Kurdish Nationalist Movement in the 1990s: Its Impact on Turkey and the Middle East edited by Robert W. Olson, Kentucky: The University Press of Kentucky, 67.

${ }^{202}$ Imset, Ismet (1992). The PKK: A Report on Separatist Violence in Turkey, Ankara: Turkish Daily News Publications, 17-20.
} 
benchmark for the evolution of the Kurdish movement in Turkey in terms of understanding not only the transformations within the Kurdish society itself, but also the significant shifts the relationship between the Kurds and the Turkish state underwent from the early 1990s onwards.

The organizational development of the Kurdish movement in the 1960s and 1970s made important contributions to the public discussion of the Kurdish issue in Turkey. Particularly in the second half of the 1970s, the Kurdish socialists became considerably assertive and influential in stressing the notions of "national oppression," "colonialism" and "national liberation," which were disseminated widely in the political magazines of the Kurdish political groups and clandestine parties. ${ }^{203}$ Although this process provided an important platform for the expression of the views of Kurdish activists and consolidation of their political position, the Turkish state's perception of the Kurdish question and the security-oriented policy making, which had dominated the state's dealings with the politically active Kurds since the early years of the republican rule, remained largely unchanged.

The Kurdish uprisings of the 1920s and 1930s were considered by the state as an artificial question originating simply from the resistance of the pre-modern tribal structures and adherences towards the dissemination of modern state power into the Kurdish-inhabited regions. Likewise, the Kurdish unrest of the 1960s and 1970s was believed to be simply an outcome of communist incitement. In other words, the Turkish

\footnotetext{
${ }^{203}$ Güneș (2012), 74.
} 
state consistently avoided recognizing the "Kurdishness" of the Kurdish question. ${ }^{204}$ This situation did not change after the emergence of the PKK as a guerilla organization in the 1980s, during which the discourse of "terrorism" and military solutions dominated the state's approach towards the Kurds. By the early 1990s, however, both the state's perception of the Kurdish question and its methods of addressing the issue started to undergo significant shifts. The endurance of the PKK both as a military and political organization was a major causal factor in effecting this transformation. The PKK's own ideological transformation in the aftermath of the collapse of the Soviet Union formed another important aspect of this process. It is the combination of these factors that eventually resulted in the interpenetration of the Kurdish question with the problem of democratization in Turkey.

The question of why the PKK emerged as the only socialist and Kurdish nationalist group that survived the widespread suppression following the 1980 coup is significant in terms of understanding the long-term consequences of the Kurdish armed struggle in Turkey. It is common in the literature to establish a direct causal link between the rise of the PKK in the post-1980 period and its use of violence against the state. ${ }^{205}$ The torture and other degrading and humiliating treatment the Kurdish activists were exposed to in Diyarbakir Prison after the coup is seen as a turning point in the radicalization of the Kurdish movement and its abandonment of peaceful opposition

\footnotetext{
${ }^{204}$ Yeğen, Mesut (1999). "The Kurdish Question in Turkish State Discourse," Journal of Contemporary History, 34 (4) 555.

${ }^{205}$ See Özcan, Ali Kemal (2006). Turkey's Kurds: A Theoretical Analysis of the PKK and Abdullah Öcalan, New York \& London: Routledge; Taspinar, Omer (2005). Kurdish Nationalism and Political Islam in Turkey: Kemalist Identity in Transition, London and New York: Routledge; Kanat, Kilic Bugra (2013). "Ending Ceasefires for Political Survival: The Use of Diversionary Strategies by the PKK Leadership" in Understanding Turkey's Kurdish Question edited by F. Bilgin, A. Sarihan, Maryland: Lexington Books.
} 
tactics. These approaches, however, have very limited explanatory power in accounting for the evolution of the Kurdish movement in Turkey since the 1980s, particularly for the transformations that took place both within the Kurdish movement itself and its relations with the state since the early 1990 s.

The argument that explains the emergence of the PKK as a reaction against the extreme state repression following the 1980 coup denies the very "continuity" of the Kurdish question in Turkey since the 1920s. This perspective explains the Kurdish movement on the basis of a narrowly defined causality confined to the state-PKK conflict in the post-1980 period and essentially seeks to construct an alternative "Kurdish reality," disconnected from its historical dynamics, internal controversies and organizational processes, and instead draws on the 1980 coup as a convenient tool to justify its arguments. $^{206}$

Turkey's Kurdish question did not emerge in 1980 with the rise of the PKK, nor did the PKK emerge as a reaction to state brutality against the Kurdish activists in Diyarbakir Prison. More importantly, the rapid growth of the PKK's influence among the Kurdish masses in the 1980 s cannot be reduced to a reaction against the oppressive political environment following the 1980 coup, but can be traced back to the early beginnings of the movement in the 1970s. At best, the impact of the 1980 coup on the Kurdish movement can be explained by the fact that the discriminatory and draconian measures adopted by the military regime between 1980 and 1983 , such as banning the

\footnotetext{
${ }^{206}$ Fırat, Bahar Şahin, Fırat, Mesut (2011). “Kürt Hareketi'ni Diyarbakır Cezaevi’ne Hapsetmek: Iktidar, Özne ve Siyaset Üzerine Eleştirel Bir Deneme" (Confining the Kurdish Movement to Diyarbakir Prison: A Critical Essay on Power, Agent and Politics), Toplum ve Kuram, 5: 93-94.
} 
Kurdish language altogether and the widespread torture in Diyarbakir Prison, provided the recruits that the PKK needed. ${ }^{207}$

Although the PKK launched its first attack in 1984, armed struggle was accepted by the organization in principle since the early 1970s. Until 1977, the PKK defended armed struggle ideologically, but without any serious attempt to engage in it. By the late 1970s, serious preparations to organize a guerilla war started and continued until the first attack against Turkish military targets in 1984. Therefore, establishing a direct causal link between the 1980 coup and the emergence of a Kurdish armed struggle is both misleading and reductionist. Furthermore, of the various Kurdish parties that emerged in Turkey in the 1970s, the PKK was the first to openly strive for "liberating" every chunk of Kurdistani territory and ultimately reunify them in "Greater Kurdistan" by using "armed struggle." It was, however, not the "only" Kurdish party to embrace the strategy of use of arms to achieve the goal of full independence for a united Kurdistan. Several other Kurdish parties, such as Ala Rizgari, KUK and Kawa, also openly declared their goal to establish an independent united Kurdish state and their belief in armed struggle as the best path to the liberation of Kurdistan.

\section{The Rise of Political Violence}

It is important to answer several vital questions regarding the evolution of the Kurdish movement after the 1980s. Why did the PKK emerge as the only Kurdish party to survive the repressive political environment of the early 1980s? How did it manage to consistently expand its social base among the Kurdish masses while other Kurdish parties

207 Çandar, Cengiz (2013). "On Turkey's Kurdish Question: Its Roots, Present State, Prospects," in Understanding Turkey's Kurdish Question edited by F. Bilgin, A. Sarıhan, Maryland: Lexington Books. 66. 
were largely marginalized in the post-1980 period? Is there a causal link between the endurance of the PKK-led armed struggle and the transformation of the Kurdish question from an ethnic issue defined in the context of "terrorism" and "separatism" to a political problem defined in the context of democratization in Turkey?

Given the low probability of victory and the high costs of participation, armed struggle is certainly the most risky path a political movement can pursue particularly if it is conducted against a state. When the 1980 coup almost completely destroyed both the Kurdish and Turkish leftist organizations, one of the main factors that distinguished the PKK from other Kurdish parties and enabled it to survive was its social base, which included a sizable portion of workers and peasants. Contrary to its popular perception, PKK is primarily a political party rather than a military organization, but it uses military means to achieve political ends. ${ }^{208}$ In this sense, what distinguished the PKK from the other Kurdish parties, as well as from the Turkish leftist groups that took up arms for achieving socialist aims, was that the party leadership put a particular emphasis on reaching political and ideological maturity and having a strong support base as preconditions to engaging in military action. The signs of this strategy can be clearly seen throughout the history of the PKK.

PKK's military struggle began after twelve years of preparation. From the first meeting of the organization's founders in 1972, to the official proclamation of the PKK in 1978 , the group carefully avoided expressing itself through any legal means; rather it formed a tightly organized and well-disciplined but open network, engaging mainly in theoretical and ideological discussions. During the second half of the 1970s, almost all

\footnotetext{
${ }^{208}$ Barkey, H. and G. E. Fuller (1998). Turkey's Kurdish Question, Boston: Rowman \& Littlefield, 26.
} 
the Turkish and Kurdish leftist groups established legal platforms for political action in the form of journals, magazines and associations. Kawa, Rizgari and Ala Rizgari published their own journals and the TKSP was widely known for its legal monthly journal, Özgürlük Yolu (Path of Freedom). ${ }^{209}$ Other illegal political parties organized legal fronts in the form of associations among which the DDKD was the most important. The original group, which later became the PKK, did not use any specific name for a long time, refrained carefully from producing any written material that would document the group's political views or organizational structure, and focused only on verbal propaganda, ideological discussions and mass communications to expand its social base. ${ }^{210}$ The reasons behind this strategy lie mainly in Öcalan's leadership skills and his cautious personality.

Öcalan was well aware of the state's relentless approach to the Kurdish issue and its violent suppression of any type of political organization involving partially or completely, the Kurds. Therefore, he concluded the group could never become a massbased influential force if it exposed itself through legal platforms. Furthermore, Öcalan himself closely experienced the years following the 1971 coup during which the cadre and leadership of the then-prominent Turkish socialist groups were killed immediately after they started rural guerilla warfare against the state. Based on the lessons from this experience, Öcalan argued that the dramatic failure of these groups derived from hasty organization and immediate, poorly-thought out and under-planned actions. With this knowledge, the group around Öcalan decided to organize itself thoroughly before

\footnotetext{
${ }^{209}$ Jongerden, Akkaya, (2011). 125.

${ }^{210}$ Yüce, M. Can (1999). Doguda Yukselen Gunes I, Istanbul: Zelal Yayinlari, 268-309.
} 
entering into a direct confrontation with the state. Throughout the 1970s, the group had a slow but steady growth by avoiding the risk of standing out too much in the eyes of the official authorities. That is why the PKK's first attack in 1984 was quite shocking for the Turkish government, which was of the opinion that it had all illegal groups under control after the military coup. The survival of the PKK in the post-1980 period cannot be explained without referring to this organizational strategy.

Muzaffer Ayata, who is a founding cadre of the PKK, points out how the organizational capacity of the PKK differentiated the party from other Kurdish organizations after the 1980 coup:

After the 1980 military coup, Turkey became a place dominated by fear, repression, torture and violence. Turkish left and the Kurdish opposition were violently suppressed, while the political arena was left to be dominated by nationalist, conservative and sectarian forces. In this political environment, only the PKK managed to resist. During the 1970s, almost all the Kurdish organizations, such as KUK, Rizgari, Ala Rizgari, DDKD, were ideologically on the same page. Everybody was defending socialism. The emergent political atmosphere of the 1980s, which was overtaken by torture and violence, revealed the differences between these parties. Strong ones survived. The PKK resisted at the risk of getting wiped out of the Turkish political scene. Its members continued to resist at the cost of their lives both in prisons and in Kurdistan. No other party could reach this threshold. That's why they were marginalized. ${ }^{211}$

The reasons behind how the PKK managed to consistently increase its influence over the Kurdish masses while other Kurdish groups became marginalized in the 1980s can also be traced back to the 1970s. Although the PKK proclaimed the creation of a unified and independent Kurdistan as its primary objective, it did not identify that as its sole goal, but also desired a radical transformation of the social and political structure of

${ }^{211}$ Interview with Muzaffer Ayata. November 28, 2011, Stuttgart. 
Kurdish society. ${ }^{212}$ After the group led by Öcalan formed their party clandestinely in the city of Diyarbakir in 1978, the PKK directed its armed struggle first against the Kurdish notables and the tribal heads. Thus, the PKK's political actions first began as an intraKurdish class struggle rather than being directed against the Turkish government. ${ }^{213}$ This reveals much about the PKK's philosophy and modus operandi. PKK announced its existence in 1978 not as an ethnic movement, but as an actor that challenges the patronage-based tribal system in Turkey's southeast. From a strategic perspective, the elimination of landlords was intended by the PKK to weaken the grip of feudal institutions over the land and people, restrict the state's indirect rule over Kurdistan through cooptation, and create room to maneuver in the countryside in preparation for rural guerilla warfare. ${ }^{214}$ At the same time, this strategy allowed the PKK to show the diffident peasantry that the PKK protects their rights and freedoms by fighting against the tribes and landowners in the region. Consequently, the PKK's image as the voice of the oppressed grew rapidly, and the party drew its leaders, members and militants largely from the disenfranchised and marginalized.

Remzi Kartal, a former member of the Turkish Parliament, explains the relationship between the PKK and the Kurdish masses as follows:

The problem in Kurdistan originates from oppression. The PKK rightfully identified this problem and gained Kurdish people's trust. Even before the PKK was established, different groups and parties engaged in propaganda in the region and told the Kurdish people about the vitality of advocating for their political rights and organizing civic action and protests. However,

\footnotetext{
${ }^{212}$ Jongerden, Joost (2007). The Settlement Issue in Turkey and the Kurds: An Analysis of Spatial Policies, Modernity and War, Leiden and Boston: Brill, 53-54.

${ }^{213}$ Çandar (2013). 65.

${ }^{214}$ Jongerden (2007). 55-56.
} 
what people needed was security. Kurdish people were ready to fight, but they were also aware of the state violence they had to confront if they take action. It is only the PKK who responded to Kurdish people's need for security. It is only the PKK who assured the Kurdish people that it would protect them if they stand up for their rights and the PKK successfully fulfilled that responsibility. That's why no other movement, but only the PKK, managed to earn people's trust and that's why the masses followed the PKK while the other Kurdish parties remained marginal. ${ }^{215}$

The Turkish state refused to consider the Kurdish aspirations or enter into political discussions on the matter and used constant threat of violence to maintain its dominance over the Kurds. However, the control of the Turkish state was seriously threatened when the PKK succeeded in gaining mass support and presenting itself as a viable alternative. ${ }^{216}$ The violence perpetrated by the PKK, it has been argued, was rational and instrumental in the sense it created political space for public debate on the Kurdish question and tried to change the social and political status of the Kurds in circumstances where there was no alternative avenue for the expression of grievances. ${ }^{217}$ The threat posed by the PKK to the political system in Turkey and the influence it had among the masses in Turkey's southeast has been recognized as the most serious challenge faced by the Turkish Republic since its establishment in $1923 .^{218}$

Whether the armed opposition of the PKK led to political gains for the Kurds and paved the way for the implementation of policy changes from the Turkish state is a significant question. Mahmut Şakar, who was one of the lawyers of Öcalan, drew

\footnotetext{
${ }^{215}$ Interview with Remzi Kartal. November 29, 2011, Brussels.

${ }^{216}$ Jongerden (2007). 53.

${ }^{217}$ Bozarslan, Hamit (2004). Violence in the Middle East: The Political Struggle to Self Sacrifice, Princeton: NJ: Markus Wiener Publishers, 23.

${ }^{218}$ Özdağ, Ümit (2003). The PKK and Low Intensity Conflict in Turkey, Ankara: Frank Cass.
} 
attention to the fact that in cases where the violence of power blocks all avenues for selfexpression, violence of the opposition becomes instrumental in forcing those in power to negotiate for a political solution:

Nobody defends violence, which is an issue that directly affects human life. However, I don't accept the understanding which views everyday violence of the state legitimate and denounces the armed resistance against state violence as terrorism. The existence of the Turkish state in Kurdistan has always been based on use or threat of force. The Kurdish movement came to the conclusion that armed struggle is imperative after decades of oppression and denial. The 1980 coup and the inhumane treatments that the Kurds were exposed to were the last straw. It was no longer possible to organize resistance through parties or associations. There is still much progress to be made for the settlement of the Kurdish question within a genuinely democratic framework. The current political conditions are different than the conditions which necessitated armed struggle in the 1980s. The PKK is aware of this reality and seeks to engage in negotiations with the state. Today, nobody denies that there are avenues available to the Kurds to express themselves politically. Nonetheless, it is also undeniable that this is a consequence of the armed struggle. ${ }^{219}$

Hatice Çoban, who is the representative of pro-Kurdish Peace and Democracy

Party in Brussels, expresses similar views:

We, as a party, accept that the PKK is not a cause but an effect of Turkey's Kurdish question. This is not about supporting or opposing the use of arms. Because we all wish that the painful process of armed struggle, which led to the loss of a lot of lives in Turkey, was never experienced and that the Kurds gained their rights through peaceful methods. This is about recognizing a reality. The reality is that the Kurdish question defined as "the Kurds' demands for rights" entered the Turkish state's agenda as a result of the PKK's armed struggle. This is undeniable. What would have happened if the Kurds never took up arms? I think we will always ask this question. ${ }^{220}$

By the early 1990s, both the Kurdish movement and its relations with the state started to undergo important transformations. Significant shifts took place not only within

${ }^{219}$ Interview with Mahmut Şakar. October 17, 2011, Cologne.

${ }^{220}$ Interview with Hatice Çoban. October 11, 2011, Brussels. 
the PKK's outlook on the solution to the Kurdish question, but also the Turkish state's perception of the Kurdish problem. The entrance of pro-Kurdish parties on to the Turkish political scene in the early 1990s marked the beginning of a crucial process in which the Kurds' armed struggle and political struggle began to go hand in hand, affecting each other as well as the larger democratic problems of Turkey in critical ways. Nevertheless, it is important to note that the PKK, particularly its leader Öcalan, continued to be the most influential actor in terms of defining the Kurdish question in Turkey and shaping the public debate on the demands of the Kurds. This process gradually expanded the boundaries of the Kurdish movement to affect not only the status of the Kurds, but also the broader political problems that concern the rights and freedoms of all citizens of Turkey. The Kurdish movement had become a force capable of influencing the political agenda of the whole country.

\section{Transformation of the Kurdish Movement in Turkey}

The PKK's political activities throughout the 1980s and 1990s led to the mobilization of large number of Kurds in Turkey. The increase in political violence during this period caused a corresponding increase in Kurdish political mobilization in the form of popularly attended demonstrations and protests. ${ }^{221}$ From the early 1990 s, the Kurdish activists also started to work within electoral politics, creating alternative channels to armed struggle to articulate Kurdish demands.

Participation of the Kurds in formal political arenas, which started with the establishment of People's Labor Party (HEP) in 1991, was a significant development in the expression of demands by the Kurds within the realm of legal democratic politics.

${ }^{221}$ Güneş (2012). 122. 
However, it is important to highlight the cause and effect relationship between the armed struggle and the entry of Kurdish activists into the Turkish political arena. These newlyemerging pro-Kurdish parties were able to find a space in formal politics largely due to the resilience of the PKK movement. One of the main consequences of the PKK's guerilla warfare was the emergence of the discourse of "terrorism" in Turkey as a novel way to delegitimize the Kurdish demands. Ironically, it is the PKK's struggle that cleared the way and opened political space for the emergence of legal, pro-Kurdish parties that could consolidate the Kurds' engagement with democratic politics and further the Kurdish movement in ways that armed struggle could not. Therefore, the mainstream proKurdish parties that have acted within the formal political arena in Turkey from the early 1990s, have always maintained a strong commitment to the articulation of the Kurdish question as originally set forth by the PKK in the 1970s.

There are fundamental questions to consider regarding the changes the Kurdish movement experienced in the early 1990s. If the main objective of the PKK-led Kurdish movement was the establishment of an independent united Kurdish state, why did the Kurdish activists increasingly turn to the formal political arena and opt for acting "within" the system? Why did the PKK take this approach when it would have been in its interests to incorporate these activists into its own ranks as recruits? The answer to these questions lies in the political and ideological transformations of the PKK since the early 1990s. Instead of viewing these transformations as a break from its initial goals, it is more appropriate to view them in the context of both the PKK's evolutionary trajectory and the changing political conditions in which it operated. 
Although the PKK specified liberation of Kurdistan as its main objective, it never depicted its struggle as an ethnic one. This was a crucial distinction between the PKK and the other Kurdish organizations in the 1970s. Although relations with the revolutionary left were common to all Kurdish groups in that period, the approach of the PKK was very distinctive. After the separation between the Turkish and Kurdish socialists, most of the Kurdish organizations turned to Kurdish nationalism as their defining ideology with the goal of leading a proletarian revolution of their own. The PKK envisaged the revolution in Turkey and Kurdistan as an intertwined process in which the center of gravity rested in Kurdistan. ${ }^{222}$ In PKK's ideology, the liberation of the Turkish people was seen as an objective that could never be accomplished without the achievement of the liberation of the Kurds. Accordingly, the Kurdish struggle was depicted not as an assignment for Kurdish nationalists, but for socialists, Kurds, and Turks alike. This was the main criticism posed by the PKK against the Turkish left. Öcalan makes this point by stating, "I turned to the Kurdish cause not because I am a Kurd, but because I am a socialist.",223 The PKK has always had a strong orientation to Turkey and weak linkages with other Kurdish parties because of its tendency to position itself at a distance from narrowly defined anti-Turk ethnic nationalism.

The Turkish left's failure to rid itself of the influence of Kemalism and the tendency to disregard the revolutionary potential of Kurdistan eventually prompted the group led by Öcalan to organize separately. However, the PKK never lost interest in Turkey's revolutionary organizations and their agendas. It is important to recognize this

\footnotetext{
${ }^{222}$ Jongerden, Akkaya (2012). 13.

${ }^{223}$ Yüce, 230.
} 
distinctive approach embraced by the founding cadre of the PKK in order to understand the transformations in the PKK's objectives in the 1990s. The PKK's success at becoming a resilient movement lies not only in its ability to transform itself according to changing political conditions, but also in its ability to maintain a mass support base even after it underwent radical transformations with regard to its objectives.

During the 1970s, the PKK followed the strategy of mobilizing the masses by emphasizing the emancipatory nature of socialist ideology and promoting socialism as a path to achieve independence and defeat colonialism in Kurdistan. Addressing the feelings of "Kurdishness" was seen as a second step. ${ }^{224}$ This approach derived specifically from Öcalan's personal outlook on the Kurdish question which, for him, could not be confined to the narrow limits of ethnic nationalism. That is why the transformation of the feudal nature of Kurdish society was seen as significant to the establishment of an independent united Kurdish state. ${ }^{225}$ From this perspective, Kurdish statehood was never depicted in the PKK's ideology as an end in itself, but as a means for the emancipation of Kurdish society. This approach gave the PKK the flexibility to redefine Kurdish "independence" according to changing political circumstances. This is exactly the reason why the Kurdish masses continued to follow the PKK despite its dramatic shift in the party's political objectives in the early 1990s, from the goal of independent statehood to finding solutions within the borders of Turkey.

\footnotetext{
${ }^{224}$ Yüce, 285.

${ }^{225}$ Öcalan, for example, has always been critical of the Kurdish parties of Iraqi Kurdistan. Many times, in his statements, he asserted that the KDP and PUK cannot liberate the people of Iraqi Kurdistan unless they transform the tribal structure of the society and political life. Accordingly, Öcalan emphasizes that even if the Kurds in Iraq secede and establish a separate state, this would not bring "independence".
} 
It is common in the literature on Kurdish nationalism in Turkey to explain the transformations within the PKK's objectives in the context of Öcalan's capture by Turkish security forces in 1999. The PKK's abandonment of the ideal of an independent Kurdistan is interpreted largely as a sign of its moderation of its goals due to the arrest of the party's leader and its declining capacity to act. This view is largely in line with the official approach of the Turkish state towards the Kurdish question in the 2000s, which portrayed the changes in the PKK's goals as a sign of weakness and a result of the PKK's defeat by the Turkish army. Although the PKK experienced severe difficulties and suffered from organizational instability from 1999 to 2004, the fact the party managed to reorganize itself and once again emerge as a serious challenge to the state after 2004 onwards proved these approaches wrong.

In fact, the PKK has neither abandoned the idea of "independence" nor its efforts to achieve the ideal of "united Kurdistan." Rather, what the PKK abandoned was only its "statist" approach towards the Kurdish question. In other words, the party still maintains the goal of an independent united Kurdistan, but tries to accomplish this goal in new ways. In this respect, the shift in the PKK's approach to the Kurdish question can be explained as a transformation of the "state-building" project to one that is centered on "society-building," which focuses not only on Kurdish society, but also on accomplishing radical political change in the whole of Turkey. Tracing the origins of the changes in the PKK's objectives to Öcalan's capture in 1999 is misleading as it does not provide a true understanding of this transformation process, which dates back to the early years of the 1990s. 
Throughout the 1990s, Öcalan's leadership was largely focused on recognizing the changing political circumstances both in Turkey and in the international arena, and explaining the need to modify its goals to both PKK members and the party's support base. The collapse of the Soviet Union and the communist bloc in 1989 was one of the main reasons behind the PKK's transformation. The definition of "Kurdishness" made by the PKK in the 1970s was based on not only "national demands," but also "socialist demands." In this respect, the party's goals were considerably affected by the Cold War conditions and the Marxist-Leninist attitude towards the national question, which was defined as the nations' right to self-determination. The dominance of this approach is clear in the PKK's founding manifesto, which rejects the solutions such as "regional autonomy," "federalism" or "linguistic and cultural autonomy" on the grounds they are against the "independent state" thesis, which is the only true interpretation of the nation's right to self-determination." ${ }^{226}$ According to Mahmut Şakar, the goals of the PKK during the 1970s and 1980s were reflected the political conditions of the period in which the PKK was born:

The PKK was born in a world where independent statehood was seen as the only solution to the problems of oppressed nations. The primary goal of the PKK was to end oppression which was originating from the denial of the identity of Kurdish community. If your goal is to mobilize this community, you have to focus on this discourse of denial. During the 1970s and 1980s, if the PKK emerged with the goal of autonomy or federalism, that would not mean much to the masses. There was need for a much stronger formulation to respond to the Turkish state violence. Turkish state was where the Kurds were denied, a Kurdish state would be the place where the Kurds would be free. It was "independent Kurdistan" which we didn't have and what we needed to hear. It sounded so good. ${ }^{227}$

\footnotetext{
${ }^{226}$ Öcalan (1978).

${ }^{227}$ Interview with Mahmut Şakar.
} 
By promoting the discourse of independent statehood and embracing the use of violence, the PKK aimed to directly address this policy of denial and open avenues for the Kurds to express their identity and mobilize their political energy. These two strategies enabled the PKK to not only challenge the core principles of the Turkish Kemalist project, but also introduce the Kurdish question as a legitimate problem on the Turkish state's agenda. In the early 1990s, however, the PKK was facing a number of dislocations. The social, political and economic conditions that necessitated armed struggle were still in place in Turkey. However, the armed struggle had already served some of the important objectives of the PKK such as the creation of a mass movement and to bring the Kurdish question to the attention of the Turkish state. By the 1990s, guerilla warfare was no longer sufficient because the movement was growing at a rapid pace and the masses were in dire need of opportunities to consolidate the political struggle. The collapse of the Soviet Union further complicated this environment by making it imperative for the PKK to build a new political/ideological perspective and an organizational structure. To address these dislocations, the PKK started to construct a comprehensive democratic discourse, which significantly altered the movement's longterm objectives and political demands for the Kurds.

Öcalan places emphasis on the importance of political struggle in the early 1990s and talks of the relationship between "independence" and "statehood":

Right now, armed struggle is escalating because we don't see any transformation in the Turkish state's approach towards the Kurdish question. However, we pay attention to political struggle too. This is not a contradiction. We engage in armed struggle not to block political avenues, but to open space for political struggle. Independence should not be understood only in the form for separatism. You cannot claim that you are independent only because you have a state. Independence represents a 
mental and moral existence. If nations are not independent ideologically and morally, regardless of whether they have a state or not, they are slaves and dependent. Nations that search for recognition from America and the United Nations worship statism. This approach enslaves people. The notion of independence that the PKK tries to provide for the Kurdish people, as well as for the other peoples - Turks, Arabs and Persians - is not merely related to the concept of state. Statehood is within our understanding of independence, but we don't want to narrow our movement down to that. ${ }^{228}$

In another interview, Öcalan places emphasis on the coexistence of the Kurds and

Turks in the context of the PKK's understanding of "independence":

I focus on the concepts of "independence," "freedom" and "unity" rather than the concept of "separation." Independence can be claimed by different people living together. We are not talking about an independent state. We are talking about a political unity in which people can think, act and develop policies on the basis of equality. The problem is that the political tradition in Turkey is not compatible with such an understanding of independence. We believe that Turks need independence too. The Turkish state tries to solve all problems only through coercion and control. What the Turkish state understands from national unity is to wipe out the popular will of the Kurds. This approach does nothing but further complicates the problems. $^{229}$

Öcalan emphasizes how peaceful and democratic coexistence of the Kurds and

Turks is fundamental to the liberation of not only the Kurdish and Turkish people, but all

the peoples of the Middle East. He introduces the term "Middle Eastern Federation" and

claims for the Kurdish movement a central role in the accomplishment of this ideal:

Achievement of unity between Turks and Kurds will pave the way for unity among all the peoples of the Middle East. This is the international aspect of our quest for independence. For us, achieving unity with the Turks on the basis of freedom and equality is much easier than achieving unity with the Kurds of Iran or Iraq. This is because of objective reasons. Other parts of Kurdistan have their own movements, class interests and

\footnotetext{
${ }^{228}$ Balli, 231-232.

${ }^{229}$ Calışlar, Oral (1993). Öcalan ve Burkay'la Kürt Sorunu (The Kurdish Problem with Öcalan and Burkay), Istanbul: Pencere Yayınları, 17-18.
} 
political structures. It is not realistic to claim unity for the Kurds without considering these dynamics. Unity with the Persians and Arabs will be a more difficult process. However, these relations will form the core components of the eventual goal of forming a Middle Eastern federation which will bring emancipation for all the peoples of the Middle East. ${ }^{230}$

The concepts of "autonomy" or "federation" did not become part of the PKK's party program for the solution to the Kurdish question until after the capture of Öcalan in 1999. A closer reading of Öcalan's statements and the meeting reports of the PKK throughout the 1990s, however, clearly indicates that the party questioned the classical statist approach to the national question and contemplated other possible solutions and their continued dependence on armed struggle. In the Political Report submitted to the Fifth Congress of the PKK, Öcalan significantly highlights these issues:

How do we define the concept of "political solution" and considering the military situation, when can it be possible? Is it realistic to impose federation in Turkey as a phase in the solution process? What would be the characteristics of such a federal system and what would be its relationship with Turkey's democracy and struggle for democratization? How can we incorporate the Turkish left and revolutionary forces of Turkey into this process? What could be the best strategy to develop a political solution which would be based on establishing relations with Turkey, other regional states and the United States without sacrificing our independence and freedom? ? $^{231}$

Öcalan's attempts to connect the solution to the Kurdish question to the democratization process in Turkey is a clear indication of the PKK's search for a new political and ideological perspective that would respond to the changing political conditions of the post-Cold War world. As his questions in the Fifth Political Report

\footnotetext{
${ }^{230}$ Ball1, pp. 236-237; Perinçek, Doğu (1990). Abdullah Öcalan ile Görüşmeler, İstanbul: Kaynak Yayinları, 118-119.

231 Öcalan, Abdullah (1995). PKK 5. Kongresine Sunulan Politik Rapor (The Political Report Presented to the PKK $5^{\text {th }}$ Congress), Weşanên Serxwebun, Köln.
} 
suggest, the PKK remained loyal to the emancipatory ideals of socialism and maintained its interest in acting in concert with the revolutionary forces of Turkey. The main critique of the Soviet Revolution by the PKK was that it was a victim of vulgar materialism as it exhausted all the energy of socialism for the growth of the economy, party and state. ${ }^{232}$ According to the PKK, the state should have been dissolved in the people, but the experience of socialism showed the process occurred the other way around; the people were dissolved to the state and the party. ${ }^{233}$ Thus, for the PKK, establishing a free individual and society was more vital than establishing a state and party. Accordingly, socialism in Kurdistan is defined as a great human revolution that does not recognize borders.

Until the late 1990s, discursive changes within the PKK did not follow a clear pattern. The party did not abandon its commitment to the construction of a socialist society, but its critique of the nation-state encouraged an increasing quest for alternative solutions based on the peaceful coexistence of nationalities without changing existing borders. In this respect, the global turn towards democracy after the collapse of the communist regimes played a significant role in the emergence of a "democratic discourse" as the most appropriate alternative for the PKK as a new strategy that would respond to the realities of the age and resonate with the growing demands for the expansion of political struggle.

The clearest indications of change were seen when the PKK declared a unilateral ceasefire in 1993 in an attempt to promote reconciliation and open the way for dialogue

\footnotetext{
232 Özcan, Ali Kemal (2006). 102.

${ }^{233}$ Serxwebun, monthly periodical of the Central Committee of the PKK, October 1995.
} 
and negotiations in order to solve the conflict through political means. Two more unilateral ceasefires followed in 1995 and 1998. These attempts at reconciliation evolved into, after 1999, a strategic transformation that truly radicalized the PKK-led Kurdish movement in Turkey. Contrary to the conventional view that armed struggle radicalized the Kurdish movement in Turkey, it is, in fact, the PKK's appropriation of the "democratic discourse" in the 2000s that represents true radicalization. What makes the movement "radical" after 1999 is that the PKK no longer sought to simply transform the Kurdish society, but asked the Turkish state and the other regional states to face their own democratic deficits. This is a considerably radical demand, particularly in a region where the primacy of the state over the individual has always been a major barrier to the establishment of genuine democracy.

\section{The PKK's Turn to Democratic Discourse}

After Öcalan's capture in 1999, the PKK entered into a comprehensive process of ideological and organizational reorganization. This process could be characterized as the implementation phase of the intense theoretical and ideological deliberations of the 1990s. Until the late 1990s, the PKK retained core socialist values, but kept its distance from "experienced" socialism represented by the Soviet regime. This provided the PKK with an opportunity to focus on the concepts of "freedom" and "emancipation" as opposed to socialism cast as a particular political regime. The focus on the individual and society, and not the state, laid the groundwork for the party's ultimate turn to democratic discourse in the 2000s. It was not Öcalan's arrest that initiated this process, but it certainly accelerated it by putting pressure on the PKK to reformulate its ideology and organizational structure. 
The evolution of the Kurdish question in Turkey in the 2000s has three defining elements that require an in-depth assessment: 1) the political and ideological change within the PKK, which was shaped largely by Öcalan's defense texts and prison notes; 2) the Justice and Development Party's (AKP) rise to power, which marked the beginning of a new phase in the Turkish state's approach to the Kurdish question; and 3) the increased influence and visibility of Kurdish parties in the formal political arena, notably the Democratic Society Party (DTP) and its successor, Peace and Democracy Party (BDP).

After Öcalan's capture, the PKK declared a permanent ceasefire in September 1999 , in order to open up space for dialogue. This was followed by an extraordinary party congress in January 2000 in which the PKK's party program underwent a complete renewal. The extraordinary congress resulted in the approval of a new program (Program of 2000), which was a systemized edition of Öcalan's defenses and included substantial changes in the party's national undertakings. In the Program of 2000, "Democratic Transformation" replaced the concept of "Kurdistan Revolution" and the prime objective was defined as "bringing the sovereign power of Turkey's oligarchic structure and its extensions on the Turkish and Kurdish peoples to an end." ${ }^{234}$ The solution to the "national question" was described as "developing a democratic political system on the base of Turkey's political wholeness and constitutional citizenship in which the free participation of Turkish and Kurdish peoples is realized.,235

\footnotetext{
234 Öcalan, Abdullah (2000). Dönüşüm Süreci Üzerine Perspektifler: Politik Rapor (Perspectives on the Transformations Process: The Political Report), Weşanên Serxwebun, Köln.

${ }^{235}$ Ibid.
} 
As the Program of 2000 indicates, the change within the PKK was more than a transformation. According to the structure of the new program, the PKK essentially declared itself as a party of not only Kurdistan but also Turkey. Nevertheless, it is evident from Öcalan's main defense that transformation of the party's national standpoint did not mean the abandonment of the Kurdish national cause. Rather, in parallel with the theoretical discussions of the 1990s, Öcalan saw the role of the PKK and the Kurdish movement as fundamental to the goal of furthering the solution of the national question within the framework of democratic transformation. The first sentence of the introduction to his main defense makes this point clear:

My defense is not so much based on detailed replies to the charges in the indictment prepared by the Chief Prosecutor [of the State Security Court], as it is about what I see as a more important topic: how to reach an historic reconciliation from a revolt under the leadership of the PKK, and increase the possibility of a solution to the Kurdish issue. ${ }^{236}$

After 2000, the PKK's ideological framework was established on the basis of Öcalan's defense texts, which were published and accepted in the PKK congresses as the official party line. Within the defense texts he submitted to the Turkish courts and the European Court of Human Rights, Öcalan highlighted two concepts: "Democratic Republic" and "Democratic Confederalism." Öcalan outlines an historical analysis of civilization, starting in the Middle East, and concludes it is the state that is the "original sin" of humanity. ${ }^{237}$ The democratic civilization that Öcalan's defenses aspire to

\footnotetext{
${ }^{236}$ Öcalan, Abdullah (1999). Declaration on the Democratic Solution of the Kurdish Question, London: Mesopotamian Publishers.

${ }^{237}$ Jongerden, Joost, Akkaya, A. Hamdi. (2011). "The PKK in the 2000s: Continuity through Breaks," in Nationalism and Politics in Turkey: Political Islam, Kemalism and the Kurdish Issue edited by Marlies Casier, Joost Jongerden, London and New York: Routledge, 152.
} 
construct in the region aims for a radical transformation of the entire Middle East through the development of pluralist democracy and civil society. ${ }^{238}$

Öcalan's proposed solution to the Kurdish question in Turkey is conceived in the light of his decentralized and democratized vision of the Middle East, in which he considers the PKK as the locus of the process of transformation. Öcalan sees the development and deepening of democracy as the key to the establishment of a Democratic Republic of Turkey, which will provide a lasting solution to the Kurdish question. The main mechanism for the unification of the Kurds, according to Öcalan, is the establishment of a democratic confederalism, which refers to the formation of selfgoverning bodies throughout Kurdistan. The mechanism will offer a way out of the current stalemate characterized by the highly centralized states in the region and pave the way for the establishment of a Democratic Middle Eastern Union in the long run.

In order to complement this ideological transformation, the PKK also underwent a process of organizational change and renewal. In its seventh extraordinary congress, the PKK first reorganized its guerilla forces, which resulted in the abolition of the old army front structure and replaced it with a new body, HPG (People's Defense Forces). Not merely a technical adjustment, the new organization introduced the PKK's new military strategy, which was designed according to the party's new programmatic focus on "democratic transformation" and political struggle rather than armed struggle. The concept of "legitimate defense" was introduced to characterize the new military strategy,

\footnotetext{
${ }^{238}$ Güneş (2012). 140.
} 
which maintained the PKK's capacity to carry out an armed campaign should the democratic political solution fail or the movement come under attack. ${ }^{239}$

In the eighth congress of the PKK, which was held in 2002, the PKK converted itself from a party to a congress under the name KADEK (The Kurdistan Freedom and Democracy Congress). It declared the conversion from "party" to "congress" better captured the movement's aspiration to become a non-power-envisaging entity. KADEK's mission was explained as one of coordinating the various new organizations necessary to the democratic transformation project in Kurdistan. Within this framework, the Congress' program conceptualized as a long-term objective the democratization of state and society across the countries in the Middle East with a Kurdish population and the construction of a Democratic Middle Eastern Union. In line with this objective, different parties were founded in other parts of Kurdistan in 2002, 2003 and 2004, respectively: the Kurdistan Democratic Solution Party (PÇDK) in Iraq, the Democratic Union Party (PYD) in Syria and the Party of Free Life of Kurdistan (PJAK) in Iran.

KADEK was replaced by Kongra-Gel in November 2003, and was renamed as the PKK in 2005. Another body called the Council of Associations of Kurdistan (KKK) was established in 2005, which later took the name the Council of Communities of Kurdistan (KCK). The KCK was founded to put into practice the idea of democratic confederalism proposed by Öcalan in his defense to the European Court of Human Rights (ECHR) in 2004, and as an alternative institutional framework to the nation-state system in the Middle East. As a loosely united confederal entity, the proposed political structure would

\footnotetext{
${ }^{239}$ Ibid. 138.
} 
neither challenge the established and internationally recognized boundaries nor resort to nationalism or attempt to establish a nation-state. ${ }^{240}$

Since his arrest in 1999 until 2005, Öcalan came under much criticism on grounds that the changes he proposed were no more than tactical moves. In response to these criticisms, Öcalan defined himself as pursuing a realistic policy by adopting alternative perspectives beyond the idealized solutions of "unlimited autonomy" or a "perfect state." He asserts that the alternative options serve the purpose of maintaining the movement and provide for the development of a political solution without sacrificing the goal of independent Kurdistan:

We need not abandon our principles in order to pursue a realistic policy. Herein we find the reason that prevents a solution to the Kurdish question: Dogmatism is confused with principle; compromise with surrender. ${ }^{241}$

From 1999 to 2005, the PKK faced various difficulties including opposition from within the organization, which resulted in a serious split in 2005, and growing frustration among the party's supporters due to lack of progress despite the permanent cease-fire and dramatic transformations with regard to the movement's goals. The PKK's strategic transformation did not fully lead to its acceptance as a democratic movement advocating for political change through non-violent means, at least on the part of the Turkish state and public in general. However, it gradually lessened the antagonistic state of relations in Turkey and put increasing pressure on the government to pursue a democratic solution. Through intensive theoretical and ideological deliberation, Öcalan and the PKK managed

\footnotetext{
${ }^{240}$ Ibid. 141.

241 Öcalan, Abdullah (2011). Prison Writings: The PKK and the Kurdish Question in the $21^{\text {st }}$ Century, London: Transmedia Publishing Ltd., 70.
} 
to get the movement in order by 2005. Despite sporadic flare-ups, armed conflict did not return to the levels of the 1980s and 1990s.

\section{The Justice and Development Party and the Kurdish Question}

After Öcalan's capture, Turkey was at a vulnerable crossroad. Benefiting from the nationalist pride Öcalan's capture had elicited among many Turks, ultra-nationalist parties made a strong showing in Turkey's parliamentary elections held on April 18, 1999. ${ }^{242}$ On the other hand, against the backdrop of Turkish nationalist pride, Öcalan's capture led to a spasm of Kurdish violence in Turkey and Europe. Instead of issuing a hard-line appeal for renewed struggle during his trial for treason that ended on June 29, 1999 with a sentence of death, Öcalan issued his call for the implementation of true democracy to solve the Kurdish problem within the existing borders of Turkey. ${ }^{243}$ Öcalan's call for a democratic solution to the Kurdish problem played a significant role in preventing the outbreak of a zero-sum game that would bring Turkish and Kurdish nationalists into a violent confrontation. It is significant that both the implicit and explicit negotiations that took place between the state and the PKK since 1999, have been built on this emergent opportunity to solve the Kurdish issue within a democratic framework, which would result in a win-win situation for both sides.

The Turkish state's ability to take up Öcalan's offer in 1999 followed an unsteady path. The decision of the government on January 12,2000 , to comply with the request of the ECHR for a stay of Öcalan's execution was a clear indication of the government's

\footnotetext{
${ }^{242}$ Gunter, Michael (2000). "The Continuing Kurdish Problem in Turkey after Öcalan's Capture," Third World Quarterly, 21 (5): 851.

${ }^{243}$ Ibid. 854.
} 
recognition of Öcalan's role in preventing the revival of armed conflict, which was essential to the development and deepening of democratization. Furthermore, a process of implicit bargaining began between the state and the PKK shortly after the capture of Öcalan, which led to several steps taken both by sides. The PKK decided to withdraw its guerilla forces out of Turkey upon Öcalan's order to end armed conflict shortly after his conviction. In August 1999, President Süleyman Demirel met with mayors from the proKurdish People's Democracy Party (HADEP) in order to engage in broad discussions, which was a clear signal the state was willing to recognize openly the legitimacy of certain forms of Kurdish political activity. ${ }^{244}$

The process of implicit bargaining between the state and the PKK remained dominated by uncertain policy responses within the Turkish political system, which can be attributed to the continued influence of Turkey's military establishment in the political arena as well as the concerns of the fragile coalition government in maintaining stability by avoiding open negotiation with either Öcalan or the PKK. The sudden arrest of three HADEP majors in February 2000, the reluctance to permit Öcalan to make statements to the press and restrictions put on his access to his lawyers, the continued emergency rule in several southeastern provinces despite the PKK's abandonment of guerilla struggle, and finally, the Turkish military attack on the PKK units in northern Iraq in April 2000 were evidence that the Turkish government would continue to pursue its own agenda. Nevertheless, although the progress towards a political solution was slow, Turkish public opinion regarding the Kurdish question changed dramatically in the wake of Öcalan's

\footnotetext{
${ }^{244}$ Ibid. p. 859.
} 
trial, which promised hope for the future establishment of peace and democracy in Turkey. $^{245}$

The rise of the conservative Justice and Development Party (AKP) to power in November 2002 opened a new chapter regarding the approach of the state towards the Kurdish question for several reasons. The main barrier to finding a political solution to the Kurdish question in Turkey has always been the fact that there was a major conflict between the state and the Kurdish actors over the conceptualization of the Kurdish question and the foundations of the Turkish Republic. The leaders of Turkish political establishment were all from secular parties, the products of education and political experience imbued with nationalist and Kemalist beliefs, which represented the very ideologies the Kurdish movement struggled against. ${ }^{246}$ Until the early 1990 s, the official approach of the state towards the Kurdish question was defined by its complete rejection of the problem. By the early 1990s, however, the government authorities started to make statements suggesting they recognized the "Kurdish reality" in Turkey. ${ }^{247}$ However, these rhetorical changes never translated into concrete practices in the political realm because of the failure to develop policies outside the Kemalist framework.

The pro-Islamic AKP came to power in 2002 with a commitment to address the Kurdish question. The main difference between the AKP and its predecessors was that

\footnotetext{
${ }^{245}$ Birand, Mehmet Ali, "Turkish Public Opinion is Softening Towards the Kurds," International Herald Tribune, July 8, 1999.

${ }^{246}$ Bahcheli, Tozun, Noel, Sid (2011). "The Justice and Development Party and the Kurdish Question," in Nationalisms and Politics in Turkey: Political Islam, Kemalism and the Kurdish Question edited by Marlies Casier and Joost Jongerden, London and New York: Routledge, 102.

${ }^{247}$ In 1992, the Turkish Prime Minister Suleyman Demirel declared "We recognize the Kurdish reality," which is accepted as the first official acknowledgement of the Kurdish question by the Turkish Republic.
} 
the AKP represented an ideology that shares common faith with Kurdish nationalism in that Islamism, like Kurdish nationalism, was defined as an existential threat to Kemalism since the foundation of the Turkish Republic. At its launching in 2001, the AKP's party program was skillfully crafted around universal themes of democracy and justice, expressed in a litany of phrases designed to resonate favorably with a wide cross-section of voters. ${ }^{248}$ In this context, there had been high expectations that the AKP government would address the Kurdish question from a democratic perspective. During the AKP's eleven-year rule, Turkey witnessed a number of important developments regarding both the solution of the Kurdish question and democratization in Turkey. However, the question of whether these developments established real political change or followed the same general direction of their predecessors, but within an Islamic framework, remained questionable. More importantly, the question the extent to which these developments were viewed as "change" from the perspective of the Kurds requires analysis.

Islamist discourse views the Kurds as fellow victims of the secular Kemalist republic and acknowledges them as people with a language and identity of their own. ${ }^{249}$ As a party that seeks to appeal to a wide cross-section of voters, AKP chose to present itself as a "democratic conservative" party which can be defined as a pragmatic mix of a general commitment to Islamic values with universal themes of justice, democracy and human rights. Regarding the Kurdish question, AKP's program put emphasis on "respect

\footnotetext{
${ }^{248}$ Bahcheli, Noel, 104-105.

${ }^{249}$ Houston, Christopher (2003). Islam, Kurds and the Turkish Nation State, Oxford and New York: Berg, 157.
} 
for cultural diversities within the framework of the democratic state of law, ${ }^{, 250}$ but did not put forward any concrete proposals. This strategy of avoiding specific policy commitments combined with moderate/conservative ideology allowed the AKP to appeal to various political groups that shared the common goal of a change of government, including the Kurds who saw the AKP as a potential challenger to the Kemalist establishment. However, after the AKP's transition from opposition to power in November 2002, it became difficult for the party's leaders to confine themselves to generalities. With no guidance to be found in their party's Program and having not previously held office, AKP had two options: either continue in the same general policy direction as its predecessors or head in some new and untried direction. ${ }^{251}$ AKP opted for the status-quo.

Throughout the AKP's administration, the Kurdish question remained one of the top items on Turkey's political agenda, particularly during the AKP's second and third terms in office. Nevertheless, despite periods of both implicit and explicit negotiations between the state and the PKK, the AKP failed to develop any coherent policy on this most critical issue. The reason for this failure lies in the defining characteristics of the AKP's approach to the Kurdish question, which can be summarized in the following way: the Kurdish problem is not about nationalism but rather forced secularism and Turkish nationalism of the type enforced by Kemalist ideology. ${ }^{252}$ Different from its predecessors,

\footnotetext{
${ }^{250}$ AKP Party Program (2001). Available online at http://www.akparti.org.tr (Accessed March 3, 2012).

${ }^{251}$ Bahcheli and Noel, 105.

${ }^{252}$ Yavuz, M. Hakan, Özcan, N. Ali (Spring 2006). “The Kurdish Question and Turkey’s Justice and Development Party," Middle East Policy, 13 (1): 103.
} 
AKP recognizes the "Kurdishness" of the Kurdish question, but calls for the subordination of such an identity to an Islamic one. In other words, from the perspective of the AKP, if Kurdishness is transformed and defined within an Islamic framework, then there will be no Kurdish question left to ponder. Thus, compared to its predecessors, AKP takes a different track with a similar bent, adopting an Islamist discourse but remaining loyal to the same statist framework as Kemalism, which was founded on the very exclusion of the Kurds. AKP's strategy can be best described as "inclusion through exclusion," which is based on the popularization of an alternative conception of Kurdishness aimed at discrediting the PKK-led Kurdish movement and presenting the AKP as the only genuine representative of the Kurds in Turkey.

Why, then, did the AKP consistently seek dialogue and negotiate with the leaders of the PKK, especially after 2007, which marks the beginning of its second term in office? This can be explained by two important dynamics: 1) the emergence of a new wave of political mobilization led by the PKK that has effectively used both armed struggle and peaceful protest since 2005; and 2) the AKP government's commitment to control the field of Kurdish politics in order to prevent possible PKK-led instabilities that would undermine its political power, particularly in the context of its fierce fight with the Kemalists to control state power. ${ }^{253}$

The eleven-year rule of the AKP witnessed a fierce competition of power between the AKP-led moderate Islamists and Turkey's Kemalist establishment, represented mainly by the Turkish military, which resulted in the clear victory of the former in 2010 .

\footnotetext{
${ }^{253}$ Ercan, Harun (2013). "Talking to the Ontological Other: Armed Struggle and the Negotiations between the Turkish State and the PKK," Dialectical Anthropology, 37 (1): 119.
} 
All engagements of the AKP, both with the PKK and the Kurdish parties in the formal political arena until the 2011 parliamentary elections, need to be understood within the context of this power struggle. During the five-year unilateral ceasefire declared by the PKK following Öcalan's capture, the cessation of political violence was portrayed by the Turkish military simply as an indication of the PKK's weakened military capabilities. The power of the AKP, on the other hand, was considerably fragile during its first term and the party's primary concern was possible threats from the Turkish military.

In this context, the PKK did not pose a major challenge to the AKP government until the completion of its ideological and organizational transformation in 2005. During this early period, AKP's attention to the Kurdish question revolved mainly around building on the reforms that had already been enacted by the previous government within the framework of Turkey's EU accession requirements. These measures were generally well received by the Kurds who saw them as a sign the Turkish state was finally beginning to fix past wrongs. Nevertheless, while removing some of the restrictions on Kurdish cultural expression, AKP carefully avoided engaging in any discussion about more politically sensitive demands such as the right to education in the mother tongue and administrative decentralization, which would risk unleashing a fierce national debate and put the government into conflict with Turkish nationalists and the Kemalist establishment.

The AKP's tentativeness gradually created skepticism among the Kurds that the AKP government was not genuine in its dealings with the Kurdish question. The PKK's decision to call off the five-year cease-fire in June 2004, further complicated the AKP's Kurdish policy. Confrontations between the PKK and the Turkish military proved that the 
PKK had maintained its capacity for armed resistance, while on the political; the Kurdish movement displayed growing success in successive elections from 2004 to 2011, increasing both the representatives in the Turkish parliament and winning the majority of municipalities in the Kurdish areas. These positive developments for the Kurds created an urgency on the part of the AKP to refine its policies to manage the growing Kurdish challenge.

\section{The Democratic Opening and the Oslo Process}

Since the end of its first term in office in 2007, the AKP followed a two-fold strategy in its approach to the Kurdish question. The first strategy was to engage in negotiations with the leaders of the PKK at the Oslo talks, which started with preliminary contacts in 2006, continued with face-to-face negotiations from 2008 to 2010, and came to a halt in 2011. The unilateral ceasefire declared by the PKK in October 2006 needs to be seen in this light. The Oslo talks took place between the PKK and Turkish officials from the National Intelligence Organization (MIT) in complete secrecy and were aimed at negotiating confidence-building measures, controlling the armed conflicts and possibly reaching a final settlement on the issue. ${ }^{254}$ As part of the confidence-building efforts the two sides agreed in October 2009 on an initial return of thirty-four PKK fighters and refugees through the Habur post on Iraq's border. Nevertheless, Habur process collapsed when the Kurds went to the border to celebrate the return of the guerillas and refugees, which was immediately depicted by the Turkish nationalists and the media as the PKK's proclamation of "victory" and an insult to the Turkish national identity. The government

\footnotetext{
${ }^{254}$ Ercan, 120.
} 
came under heavy pressure by the hard-line nationalists and the Kemalist opposition, and the process failed to serve its purpose when the returnees were later charged in Turkish courts, many of fled back to Iraq, and a planned return of diaspora exiles in Europe was cancelled. ${ }^{255}$ Öcalan's lawyers explain the Habur incident as follows:

Thousands of Kurds went to Habur to celebrate the return of guerillas. There was a reason for that. For the first time, their children were back home alive and not in coffins. For the first time, there was hope for peace. This was the reason for all the joy and happiness. However, upon reactions from the media and opposition parties, the government instantly stepped back. The idea of peace groups was negotiated between the government and Öcalan. They knew that the groups would come to Turkey. If the government was brave enough to stand by the Habur process and declared its support for the return of other peace groups, today we might have been at a completely different point within the peace process. ${ }^{256}$

What is wrong with people cheering for peace? The reactions of the government and society are completely psychological and a result of sovereign mentality. It was thought that the whole idea of peace groups is turning into a demonstration of the PKK's victory and the defeat of the government and Turkish army. Turkish society lost thousands of its children in this conflict. So, it was hard for a lot of people to put up with those scenes. It could have worked if the government was able to administer the process properly. The peace process could have continued if the government declared that those demonstrations were about peace and not victory. There are no winners and losers in a peace process. Peace is a win-win situation for all parties. ${ }^{257}$

The second strategy of the AKP towards the Kurdish question in the post-2007 period is the so-called "Kurdish opening," which was initiated in July 2009 with the purpose of finding a democratic solution to the Kurdish question. Although it was depicted as a genuine attempt by the government to settle the Kurdish question, the

\footnotetext{
${ }^{255}$ International Crisis Group, "Turkey: The PKK and a Kurdish Settlement," Europe Report No. 219, September 11, 2012, 3.

${ }^{256}$ Interview with İbrahim Bilmez, October 25, 2011, İstanbul.

${ }^{257}$ Interview with Faik Özgür Erol, October 25, 2011, İstanbul.
} 
initiative was not a "spontaneous" act of democratization. There were ongoing lowintensity confrontations between the Turkish military and the PKK in northern Iraq from early 2008. In order to break the stalemate, in early 2009 , Öcalan declared that he would announce a "road map for the resolution of the Kurdish question" by August. Öcalan's declaration created a momentum within the government to pre-empt his plan and announce a counter "Kurdish initiative" that would render Öcalan's plan useless. ${ }^{258}$ Furthermore, in the municipal elections of March 2009, AKP lost against the pro-Kurdish Democratic Society Party (DTP) in the predominantly Kurdish towns in southeastern Turkey. Thus, the AKP's Kurdish opening was indeed a response to Öcalan's road map and its decreasing electoral popularity among the Kurds.

After the initiation of the opening, AKP made a substantial effort to make sure it was pursuing all possible options without Öcalan's involvement. To this end, when Öcalan finally gave his 'road map' document to his lawyers in August, it was confiscated by the İmrali prison administration. ${ }^{259}$ The credibility of the Kurdish opening, however, soon became questionable. First, the opening was born into an environment dominated by a repressive campaign against the Kurdish politicians and activists called "the KCK operations," which started two weeks after the victory of the Kurdish movement in municipal elections in March 2009. Systematic waves of repression continued throughout the opening and led to the arrest of more than 1500 politicians, human rights activists,

\footnotetext{
${ }^{258}$ Unver, H. Akin (December 2010). "Turkey’s Kurdish Initiative: What Went Wrong? (Or dit it?)," Turkish Policy Center Reports.

${ }^{259}$ Ibid.
} 
writers, artisans, and leaders of civil society organizations. ${ }^{260}$ Consequently, in the eyes of the Kurds, the credibility of both the AKP and its Kurdish initiative was considerably damaged due to the fact that the opening went hand-in-hand with an official strategy aimed at paralyzing the legal Kurdish movement by closing the political system to it.

Second, AKP failed to engage the pro-Kurdish Democratic Society Party (DTP), one of the three opposition parties in the Turkish parliament, because of the DTP's refusal to condemn the PKK, as demanded by the government as a precondition for negotiations. The other two opposition parties in the parliament, the Kemalist CHP (Republication People's Party) and ultra-nationalist MHP (Nationalist Movement Party) also rejected the initiative as it soon became evident the AKP did not have any specific proposals regarding the opening. In addition, shortly after the Chief of General Staff İlker Başbuğ's statement on August 25, 2009, regarding the military's commitment to unitary and Turkish character of the republic, the "Kurdish" part of the initiative disappeared from the AKP's discourse and the title of the plan became "democratic opening."

In late October 2009, the Habur incident brought the stalling democratic opening to a full halt. The Constitutional Court's decision to ban the DTP for its alleged association with the PKK only made matters worse. The Peace and Democracy Party (BDP) quickly succeeded the DTP, but mass arrests and detentions against the BDP party members continued within the framework of the KCK operations. The democratic initiative news gradually disappeared from the media agenda only to be revived by the

\footnotetext{
${ }^{260}$ Gunter, Michael (Summer 2013). "Reopening Turkey's Closed Kurdish Opening," Middle East Policy, 20 (2): 89.
} 
AKP in January 2010, this time titled "National Unity and Brotherhood Project," which was more of a move to save face rather than a direct contribution to the process.

\section{The Limits of the AKP's Kurdish Policy}

The main problem with the AKP's Kurdish opening was that it was not designed as a genuine attempt to solve the Kurdish question in dialogue with the Kurdish political actors. Rather, it was initiated as part of the AKP's "containment" strategy towards the Kurdish movement, particularly in formal politics, in order to strengthen the claim that the AKP was the only true representative of the Kurds in Turkey. ${ }^{261}$ While the legal Kurdish movement was suppressed through the KCK operations, Öcalan was specifically kept out of the democratic opening process in order to consolidate the position of the AKP as the sole agent of the solution. Nevertheless, secretive talks with Öcalan and leaders of the PKK were already occurring through the Oslo process. The AKP did not succeed in administrating these parallel processes in a coherent way mainly because of its greater commitment to win the fight against the Kemalist establishment over providing a genuine solution to the Kurdish question.

From early 2010 until the June 2011 parliamentary elections, the process of finding a democratic solution to the Kurdish question was stalled. The Kurdish actors continued to put forward proposals for negotiation, but did not receive any concrete responses from the government. On the political front, the pro-Kurdish non-governmental organization, Democratic Society Congress (DTK), and the BDP were voicing a solution titled "Democratic Autonomy," which was an attempt to forge a new political paradigm

\footnotetext{
${ }^{261}$ Ercan, 120.
} 
based on the direct exercise of people's power through village, town and city councils. ${ }^{262}$ Instead of autonomy based on "ethnicity" or "territory," it suggested regional and local structures that would allow for the expression of cultural differences. ${ }^{263}$ In this respect, the democratic autonomy project is built on the idea of developing the autonomous capacities of people, through a more direct, less representative form of political structure that could be applied not only to the Kurdish region, but to the whole of Turkey.

The democratic autonomy model is in line with the guidelines already listed in the European Charter of Local Self-Government adopted in 1985, and was ratified by fortyone countries, including Turkey (with numerous reservations). The removal of the reservations and full implementation of the Charter has been part of Turkey's EU accession requirements since 2005. In that sense, one might argue that the democratic autonomy model as well as the BDP's and Öcalan's earlier calls for local autonomy would bring Turkey into conformity with the EU guidelines. Although the democratic autonomy proposal did not receive any concrete policy responses from the government, it started a heated debate in Turkey regarding strengthening of local administrations. In 2010 and 2011, the debate on democratic autonomy and local administrations also initiated a renewed phase of rapprochement between the Kurds and the Turkish left around the common theme of deepening the process of democratization in Turkey. This process paved the way for a wider political realignment in the June 2011 parliamentary

\footnotetext{
${ }^{262}$ Jongerden, Joost, Akkaya, A. Hamdi (2014). "Confederalism and Autonomy in Turkey: The Kurdistan Workers' Party and the Reinvention of Democracy," in The Kurdish Question in Turkey: New Perspectives on Violence, Representation, and Reconciliation edited by Cengiz Gunes, Welat Zeydanlioglu, London and New York: Routledge, 193.

${ }^{263}$ Ibid. 193-194.
} 
elections when the BDP formed a coalition with some twenty socialist parties and movements, which won thirty-six parliamentary seats.

On the part of the PKK and Öcalan, the Oslo talks continued until the June 2011 elections. Öcalan prepared three protocols on the principles to be followed and actions to be taken for ultimate peace. Some of the specific suggestions were the formation of a peace council, truth commissions, a democratic constitution, mutual forgiveness, political decentralization and recognition of Kurdish collective rights. ${ }^{264}$ Nevertheless, although Turkish authorities repeatedly stated the government would deliver its decision regarding the protocols after the parliamentary elections, the expected meeting did not take place, which practically ended the Oslo process. In the meantime, the AKP succeeded in taking the army and other elements of Kemalist bureaucracy under its tight control in 2011, and won its third election victory in June 2011 by getting fifty percent of the votes. Remzi Kartal explains how these developments were interpreted by the PKK:

Democratic opening was not an initiative planned by the AKP. It was the AKP's response to its defeat in southeastern Turkey in the 2009 municipal elections and to the public discussion which started as a result of Öcalan's proposed road map. AKP started this initiative but it had no preparation or a specific project. That's why it failed. That's also the reason why the Habur process collapsed. In order to overcome the stalemate, once again, Öcalan made a call and the PKK declared "no-action period" until the 2011 general elections. The PKK supported the AKP against the Turkish military with the expectation that the government will take the necessary steps for the solution of the Kurdish question after the elections. In the meantime, however, the AKP eliminated the power of the military and we saw that nothing changed after the elections. For us, the AKP government no longer has any credibility. From now on, progress on the solution of the Kurdish issue can be achieved only through mutual effort. ${ }^{265}$

\footnotetext{
${ }^{264}$ Ercan, 120.

${ }^{265}$ Interview with Remzi Kartal.
} 
From the perspective of the PKK, both the democratic opening and the Oslo negotiations were designed by the government as tactical diversions in order to both win the fight against the Kemalist establishment and implement a successful election campaign during the PKK's "no-action period." As the AKP lost its credibility in the eyes of the PKK, armed conflict resumed in 2011, shortly after the parliamentary elections and increasingly continued in 2012, until the historic Newroz statement of Öcalan. The statement renewed hope for peace and marked the beginning of yet another process of negotiation between the state and the Kurdish actors, this time openly including the PKK, Öcalan and the legal Kurdish parties.

The AKP's victory against the Kemalists was a positive step towards Turkey's democratization, particularly in terms of eliminating the influence of the military in politics. However, marginalization of Kemalism in Turkey during the AKP's rule was largely a consequence of the steps taken by the AKP to solve of the Kurdish question. Since the beginning of the AKP's first term in office, it was mainly the Kurdish issue, particularly the PKK, that shaped the course of power struggles between the AKP and the Kemalists. In this context, political violence pursued by the PKK was the biggest challenge facing the AKP in its struggle against the military. The AKP-PKK negotiations should be understood in this light. The democratic opening and the Oslo process were essentially part of the AKP's containment policy towards the Kurdish movement. The unintended consequence of this process was that it encouraged a shift in the "way of looking" at politics in Turkey, particularly regarding some important domestic issues which have long been considered as taboo. 
When a tape recording of the Oslo meetings was leaked to the media in September 2011, the incident did not lead to a public indignation, which was a major indication of strong public support for peace through negotiations with not only the legal Kurdish parties, but also with the Kurdish actors that have long been considered as "terrorists" and "separatists." It is important to recognize the role of the Kurdish movement in encouraging this shift in the mindset of Turkish society, which has made it possible for the AKP to carry out open negotiations with all the actors of the Kurdish movement, legal and illegal, since March 2013.

\section{The Road Ahead}

The AKP's engagement with the Kurdish question has not brought sustainable results mainly because the AKP replaced the power of Kemalism in Turkey not with the power of people, but with its own party establishment. Therefore, the conflict between the state and the Kurdish movement over the conceptualization of the Kurdish question, which has been the fundamental barrier to any meaningful solution, still prevails. The risky nature of "peace," which requires transformation of Turkey's ideological and political structures that have long been based on specific ethno-national hierarchies, is still largely in contradiction to the AKP's pragmatic, cautious and risk-averse approach to the Kurdish question.

Nevertheless, alongside the debate over whether the negotiations between the state and the Kurdish movement were a "success" or a "failure," it should also be recognized that the democratization discourse has gained considerable strength in Turkey since 2007. In their quest for a new definition of governance and citizenship in Turkey, the Kurdish actors saw the AKP's rise to power as an opportunity for establishing 
genuine peace and democracy in Turkey. Given the fifty percent voter support behind the AKP, the political environment in Turkey from 2007 to 2011 offered an opportunity to solve a number of important political problems, including the Kurdish question, through public consensus. The opportunity was missed, but the increased democratic consciousness in the country came back to haunt the AKP government in 2013 when the government faced mass-based protests known as the "Gezi Movement."

The Gezi movement started as a protest against the implementation of an urban management project in Istanbul in June 2013, but quickly gained momentum and spread to other cities. In a matter of days, the Gezi movement became a broad-based civilian resistance and expanded beyond its environmentalist focus to include subjects such as the restrictions on freedom of expression and the crackdown on opposition in Turkey. The AKP survived the Gezi protests, but its hold on power was severely shaken. By the end of 2013, the AKP was also shaken by serious corruption charges, which put the legitimacy of the party at further risk.

What makes this picture even more complicated is the slow pace of negotiations with the Kurds since March 2013, and the approaching local and general elections in Turkey in 2014 and 2015, respectively. Under these conditions, the AKP has once again turned to the Kurdish movement in order to maintain its power. As part of its preparation strategy for the elections, the AKP is increasingly using the Kurdish question and the nascent negotiation process with the PKK and Öcalan in order to strengthen its political leverage. The main manifestation of this strategy so far is the AKP's efforts to establish a direct connection between the fate of the solution process and the continuation of the AKP's majority power in the parliament. Considering the lessons of the past, it is 
unlikely the Kurdish movement will continue to support the ongoing peace process unless genuine steps are taken by the AKP. ${ }^{266}$ First and foremost, these steps must include the necessary constitutional changes to provide all ethno-national groups in Turkey with equal rights as well as the dismantling of centralized political structures.

\footnotetext{
${ }^{266}$ For an analysis of the ongoing peace talks in the context of the AKP's corruption scandal see Çandar, Cengiz. "Kürtler Yolsuzluk Şaibesi Altındaki İktidara Omuz Verir mi?" (Would the Kurds Support a government Stained by Corruption Charges?) Radikal, February 21, 2014.
} 


\section{CHAPTER V}

\section{KURDS IN SYRIA}

We demand a fundamental change to the oppressive system. There are some who hold up the slogan: the fall of the regime. In contrast we demand the fall of the oppressive authoritarian system. Our problems are not problems of powers. The ruling powers in Damascus come and go. For us Kurds, this isn't so important. What is important is that we Kurds assert our existence. The current regime does not accept us, nor do those who will potentially come into power. Our politics differ from a politics that seeks power. That needs to be clear. ${ }^{267}$

Syria is the last destination of the wave of uprisings in the Arab world that started in Tunisia in early 2011, and gradually spread to a large number of countries in the Middle East. Although the outcome of the Syrian revolution remains unforeseeable given the violent handling of protestors by the Syrian regime, and a heterogeneous and fragmented protest movement, there is an increasing demand for the fall of the regime. Nonetheless, as the statement made by the chairman of the Democratic Union Party (PYD), one of the most influential Kurdish parties in Syria, indicates, the Kurdish position concerning the recent political developments in Syria differs fundamentally from the position of the Syrian opposition regarding the issues of regime change and democratization in the country.

As the political events in Syria unfolded since March 2011, the relationship of the Kurdish parties to the Syrian opposition has become one of the most controversial matters in Syrian politics. Although they share the Arab oppositional groups' discontent with the current regime, the Kurds' participation in the Syrian uprising was limited and

\footnotetext{
${ }^{267}$ KurdWatch, Interview with Salih Muslim Muhammad, Chairman of the PYD, November 8, 2011. Available at http://kurdwatch.org/html/en/interview6.html (Accessed November 14, 2012).
} 
their regions remained have relatively calm. Since the beginning of the protest movement, the Kurds in Syria followed the strategy of becoming part of the revolution in order to further strengthen their case and criticize the dominant positions of both the regime and the opposition from a specific political position. In this regard, they demonstrated less for "toppling the regime" than for the Kurdish right to selfdetermination and "changing the entire system."

Until the Qamishli revolt of 2004, and particularly the Syrian uprising of 2011, the Kurdish question in Syria was overlooked both by the academic and policymaking communities, while attention has been lavished mainly on the Kurds of Turkey and Iraq, and more modestly on the Kurds of Iran. This situation is often explained by the fact that the Kurds of Syria are less numerous than those of Turkey, Iran, and Iraq, and more geographically dispersed, which accounts for their weaker mobilization in challenging the government in demand of their rights. ${ }^{268}$ Moreover, a major factor that distinguishes the Syrian Kurdish movement from its counterparts in Turkey, Iran and Iraq is that the Syrian Kurds have never taken up arms against the government of Damascus, while armed struggle has represented the primary mode of opposition for the Kurdish movements elsewhere. Therefore, the process through which the Syrian Kurdish parties were able to promote the "Kurdish issue" as a political problem to be resolved in Syria a situation which normally emerged after a period of armed conflict in other parts of Kurdistan - was slower compared to Turkey, Iran and Iraq.

\footnotetext{
${ }^{268}$ Vanly, Ismet Chériff (1992). "The Kurds in Syria and Lebanon" in The Kurds: A Contemporary Overview edited by Philip G. Kreyenbroek, Stefan Sperl, London \& New York: Routledge, 112.
} 
The Kurds constitute the largest ethnic minority in Syria, making up almost ten percent of the population, a not-inconsiderable proportion of Syrian society, and they have their own distinct language, culture and ethnic identity. ${ }^{269}$ Although the Kurdish movement in Syria was not as effective as it was in Turkey, Iran and Iraq in terms of influencing the movement for change, it played a significant role in linking the ethnic question to political goals in the country throughout the 1950s, and later during the Baathist regime.

The growth of a national consciousness among the Syrian Kurds was affected largely by the arrival of Kurdish immigrants in Syria from Turkey where they faced persecution following the Kemalist rule's brutal suppression of the Shaykh Said revolt of 1926. In the long term, the Kurdish movement in Syria became an autonomous struggle in an environment promoting the growth and affirmation of Arab nationalism, a powerful antagonist to the aspirations of the Kurds. Since the 1990s, the steady increase in Kurdish outspokenness in articulating their demands in Syria, combined with dramatic changes in the Kurdish political landscape at the regional level, resulted in renewed efforts by the Syrian Kurds to assert themselves as important political players in their own right. These efforts gradually expanded the boundaries of the "Kurdish problem" in Syria beyond the narrow limits of an "identity movement" to encompass the broader role of a

\footnotetext{
${ }^{269}$ The Syrian constitution (1973) calls the country "the Syrian Arab Republic" (Article 1), which implies that all its citizens are to be considered Arabs regardless of their ethnic origins. Therefore, there are no official statistics on the number of Kurds in Syria. For recent estimates of the Kurdish population in Syria see Nazdar, Mustafa (1993). "The Kurds in Syria" in A People Without A Country: The Kurds and Kurdistan edited by Gerard Chaliand, New York: Olive Branch Press, 194; McDowall, David (1996), 466. During February 2012, a new constitution was put to referendum which came into force on February 27 , 2012. The new constitution did not include any changes with regard to the Arab character of the Syrian nation. The referendum was boycotted by both the Syrian opposition and the Kurdish parties.
} 
"democratization" movement and respect for the human rights of all, a theme to which various groups could relate.

\section{Institutionalization of Kurdish Nationalism in Syria}

The Kurdish struggle to present their grievances by mobilizing through political parties dates back to the establishment of Kurdish Democratic Party in Syria (KDPS) in 1957. In fact, there have been many Kurds in positions of power and influence in Syria since the beginning of the French mandatory period through employment in the military and as deputies in the Syrian Parliament. Nevertheless, the Kurdish members of the parliament never presented themselves under the banner of a nationalist discourse, proclaimed their Kurdish background or promoted specifically Kurdish interests. They were considered "independents" who did not seek to create a political apparatus around their ethnic origin. Therefore, for the better part of the 1950s, the militancy of the politicized Kurds was associated with the Syrian Communist Party (SCP). ${ }^{270}$

Towards the end of the French mandate in Syria, the political engagement of the Kurds could be classified into three camps: Arab nationalism, Communism, and Kurdish nationalism. ${ }^{271}$ Some of the Kurdish tribes supported the Syrian independence movement in 1946 alongside Arab tribes. In the absence of any well-defined Kurdish groups or political parties with a Kurdish nationalist agenda, some of the politically engaged Kurds sympathized with the SCP in late 1940s. During that time, there was a widely held perception among minorities of the Middle East that communism might be their only bulwark against the pan-Arabist plan. Nonetheless, despite the fact that the SCP largely

\footnotetext{
${ }^{270}$ Tejel, 86.

${ }^{271}$ Ibid. 42.
} 
influenced the development of Kurdish nationalist politics, the conflict between nationalism and communism soon resulted in the dilution of the Kurdish identity of the party. The reluctance of the SCP to support Kurdish nationalist aspirations made it necessary for the Kurds to create an organization that was both left wing and nationalist.

The foundation of the KDPS addressed this demand by introducing the first popular Kurdish national party on the Syrian political scene. Syrian-Arab official discrimination against the Kurds, which became prominent after Syria gained independence from France in 1946, was the major impetus behind the rise of Kurdish nationalist activity in Syria. The struggle for Syrian independence was primarily fought not in terms of a "Syrian" nationalist discourse, but as one of "Arab" nationalism, which established pan-Arabism as the official ideology of the new state. ${ }^{272}$ The creation of the KDPS was a reaction to the ascending Arab nationalism in Syria in the 1950s and the exclusionary character of the emerging Syrian national identity, which denied the multiethnic and multi-religious make-up of the country.

The KDPS embraced the Syrian state as the institutional framework within which the rights of the Kurds would be sought, yet the party program explicitly promoted a nationalist discourse with a strong ethnic tone. Paragraph one of the program states that the party was founded in order to "protect the Kurds from mistakes, oppression, and from disappearing. ${ }^{273}$ Paragraph four defines the goal of the party with regard to the Kurdish question by stating that “... the KDPS demands special status for the four hundred

\footnotetext{
${ }^{272}$ Lowe (2007). 291.

${ }^{273}$ KurdWatch, Report 8, 6.
} 
thousand Kurds in the Jazirah, in 'Ayn al-'Arab, and Çiyayê Kurmênc (Afrin region), in order to ensure their political, social, and cultural rights within the Syrian state."274

Paragraph two of the program not only takes a position on the form of government sought, but also sets forth the understanding that it is only through democracy that Kurdish rights can be secured: "Because the Syrian Democratic Kurds' Party is a peace-loving and progressive party, it champions a people's democracy in its homeland Syria." ${ }^{275}$ Along with Kurdish nationalist positions, the program also reflects leftist principles and ideas. Paragraph five states: "The KDPS welcomes the Kurdish fight in Turkey, in Iran, and in Iraq, as well as the fight of all oppressed peoples for the liberation of their states from the imperialists. The KDPS will lend them a hand so that they secure their freedom. ${ }^{276}$ Here it becomes clear the party had a regional approach to the Kurdish issue and adopted a broad conception of liberation that pertains not only to the Kurds but to all the oppressed people in the region.

From its foundation in 1957 to the 1990s, the KDPS suffered heavily from splits deriving from internal divisions and ideological differences. Factionalism and fragmentation took a serious toll on Syrian Kurdish politics and created constant frustration on the part of ordinary Kurds who hoped for political strength. Nevertheless, the KDPS laid the foundations for the institutionalization of the Syrian Kurdish political scene and provided Kurdish nationalism in Syria with an organizational framework. The party was influenced greatly by regional events, particularly the evolution of the Kurdish

\footnotetext{
${ }^{274}$ Ibid. 6, 7.

${ }^{275}$ Ibid. 6.

${ }^{276}$ Ibid. 7.
} 
problem in Iraq. The leaders of the Kurdistan Democratic Party of Iraq played a decisive role in the building of the KDPS program, which later served as a platform for the Iraqi Kurdish parties to influence Kurdish politics in Syria.

Anti-Kurdish sentiment increased in Syria particularly after the union between Syria and Egypt in 1958. The newly created United Arab Republic (UAR) adopted a fiercely Arab nationalist rhetoric, which intensified anti-Kurdish propaganda and a campaign of arrest and detention against Kurdish political activists. In 1960, Gamal Abdul Nasser's rule imposed a heavy crackdown on the nascent Kurdish political movement in Syria and arrested large numbers of members and associates of the KDPS. Mullah Mustafa Barzani's uprising in Iraq in 1961 further fueled fears of a similar uprising in Syria and reinforced the perception that the Kurds posed a threat to Syria's sovereignty, security and territorial integrity. In the provisional constitution drafted after the collapse of the UAR in 1961, Syria was formally described for the first time as the "Syrian Arab Republic," which marked the denial of non-Arabs in the official ideology. This was followed by an extraordinary census in 1962 in al-Hasaka province, which arbitrarily stripped 120,000 to 150,000 Kurds of Syrian citizenship, leaving them without basic civil rights, and condemned to poverty and discrimination. ${ }^{277}$ The census allowed Syrian Kurds to pitch deeply into the discourse of victimhood, which continued to define Kurdish nationalism in Syria over the subsequent decades under the Baath rule.

\footnotetext{
${ }^{277}$ Lowe, Robert, (January 2006). "The Syrian Kurds: A People Discovered," Chatham House Briefing Paper, London, 4.
} 


\section{Hafez Al-Assad's Game}

Kurdish nationalism in Syria was largely dormant during the 1970s and 1980s because of the weight of official suppression. Nevertheless, the reawakening of Kurdish political activity in the 1990 s, which eventually culminated in the events of 2004, has its roots in the Baath era under the presidency of Hafiz Al-Assad. After the Syrian Baathists came to power in 1963 , the KDPS was banned and the party leaders were thrown into prison. The Baathists attached great importance to the consolidation of the status of Arab nationalism as the central element of Syrian political culture, started a relentless Arabization campaign in the Kurdish inhabited areas of Syria ${ }^{278}$ and increased coercion on the cultural, economic, and political life of the Kurds.

While the Baath policy towards the Kurds from 1963 to 1970 was marked by coercion as a method of managing the Kurdish problem, after Hafiz Al-Assad came to power in 1970, the regime adopted a more pragmatic approach by pursuing a policy of cooptation towards the Kurdish groups both within and outside of Syria. In Syria, besides the policy of repressing Kurdish political and cultural activity, Hafiz Al-Assad encouraged Kurdish participation in the Baath system. The Kurds were given positions in the military and the parliament only on the condition they would not embrace any particular consciousness with regard to Kurdish identity. Outside the borders of Syria, the regime provided the Kurdish groups fighting against Turkey and Iraq with relative freedom of action in Syria from the 1970s until the late 1990s, as part of its strategy to displace "its" Kurdish problem to the neighboring countries. This policy of cooptation

\footnotetext{
${ }^{278}$ The Arab belt plan was put into effect in the Jazira province after the Baathists came to power in 1963 . The plan anticipated massive deportation of the Kurds who were living in this area and their replacement by Arabs with the stated objective of "saving Arabism in Jazira".
} 
towards the Kurds of Turkey and Iraq not only served to facilitate the achievement of Assad's regional ambitions, but also enabled him to keep the Kurdish movement in Syria under control by encouraging the polarization of Syrian Kurds between the partisans of the Kurdish movements in Turkey and Iraq.

Assad's game initiated the long-term Syrian strategy known as the "playing the Kurdish card," which remained a crucial aspect of the Kurdish question as a regional phenomenon. Tension between Syria and Iraq, which manifested itself primarily in the struggle for Baathist ideological legitimacy in the 1960s, continued into the 1990s, and gave rise to increasing regional competition between the two countries, particularly after the 1991 Gulf War. During the 1970s, the conflict between the two major Kurdish parties in Iraq, the Patriotic Union of Kurdistan (PUK) and the Kurdistan Democratic Party (KDP), was the primary obstacle to any serious attempt by Syria to play the Kurdish card against Iraq. However, after the reconciliation between the PUK and the KDP in 1987, the ties between the Iraqi Kurdish parties and Damascus grew stronger. The weakening of the Baathist regime and the emergence of a Kurdish zone in northern Iraq following the Gulf War reduced Damascus' interest in an alliance with the Iraqi Kurdish parties. However, both the PUK and the KDP kept offices in Damascus until 2003.

The strategic alliance between Damascus and the Iraqi Kurdish parties ended after the American intervention in Iraq in 2003. The political gains made by the Iraqi Kurds after Saddam Hussein's fall led to a shift in the Iraqi Kurdish parties' approach toward the Kurdish issue in Syria. As a result of increased security, the Iraqi Kurdish leadership became more confident promoting the Kurdish cause in other countries. The implications of this change in the Iraqi Kurdish perspective were seen during the events of March 
2004 in Syria and later during the Syrian uprising in which Masoud Barzani played an active role in uniting the Syrian Kurdish opposition.

The conflict between Turkey and Syria dates back to the mandatory period when France transferred the Sanjak of Alexandretta from Syrian to Turkish control in 1939. The dispute over sharing the Euphrates River and Turkey's water projects, which threatened Syria's water supplies, further exacerbated already existing problems between the two states. In an effort to put pressure on Turkey, Assad took an interest in the Kurdish movement in Turkey in the 1980s, and allowed the Kurdish insurgent group, the PKK, to establish bases on Syrian territory from which the PKK militants were able to launch military operations against the Turkish army. The leader of the PKK, Abdullah Öcalan, who fled to Damascus before the 1980 coup d'état in Turkey, caused major friction between Damascus and Ankara until Öcalan's expulsion from Syria in 1998.

Although the tensions between Turkey and Syria slowly began to cool after the capture of Öcalan in 1999, the efforts to establish closer commercial and military ties between the two countries broke down as a result of the eruption of the Syrian uprising in 2011. Turkish-Syrian relations once again became strained due to Turkey's support of the Syrian opposition's efforts to overthrow the regime as well as the alleged support of Bashar Al-Assad for the Democratic Union Party (PYD) in Syria, which has close links with the PKK.

Kurds in Syria served heavily in the armed struggles of the Kurdish movements in Iraq and Turkey, mainly in Mulla Mustafa Barzani's insurgency in Iraq in 1961-1975 and in the PKK's struggle in Turkey from the early 1980s to the present. Throughout the 1980s and 1990s, northern Syria became the primary breeding ground for the PKK. As 
emphasized by Ismet Sharif Vanly, the cooperation between the PKK and the Syrian regime was of mutual interest to both parties: the PKK had a rear base in Syria for its military activities against the Turkish government and Hafiz Al-Assad had in the Kurds of Syria a shield against its internal and external enemies. ${ }^{279}$ Support from Damascus for the Kurdish parties of both Turkey and Iraq was available only on the condition that they would avoid any attempt at mobilizing the Syrian Kurds against Hafiz Al-Assad's regime. Thus, until the late 1990s, Kurdish elements in Syria acted largely as President Assad's personal guard against internal threats.

Assad's policy of cooptation of the Kurdish groups both within and outside of Syria had two conflicting consequences. On the one hand, the freedom of action enjoyed by the Iraqi Kurdish parties and the PKK came at the expense of the development of a Kurdish movement in Syria. The more dramatic struggles of the Kurds in Iraq and Turkey attracted the Syrian Kurds in great numbers to support the Kurdish cause in these countries. Nevertheless, the strategy of the Turkish and Iraqi Kurdish groups to avoid antagonizing their host and supporter resulted in denying the legitimacy of any Kurdish demands in Syria, a position that fit nicely with Assad's desire to channel Syrian Kurdish nationalist discontent towards Turkey and Iraq.

On the other hand, Assad's desire to minimize Kurdish mobilization in Syria by supporting the Kurdish movements of neighboring countries led to the unintended consequence of strengthening Kurdish identity and Kurdish nationalist sentiments among the Syrian Kurds. The Kurdish population in Syria gradually became more conscious of

\footnotetext{
${ }^{279}$ Vanly, 132.
} 
ethnic distinctions because of the weight of official suppression and the influential struggles of Kurdish groups across Syria's borders. As Kurdish cultural and political activity was continuously restricted in Syria, membership in the Iraqi Kurdish parties and the PKK were the only spaces left for the Syrian Kurds for ethnic expression and militancy. While the Kurdish movement in Syria pragmatically kept quiet and avoided challenging the regime in the Syrian context, the activities of the PKK and the Iraqi Kurdish parties made it possible for the Syrian Kurds to remain politically mobilized. This situation laid the foundations for the eventual collapse of the strategy of "dissimulation" 280 among the Kurdish groups in Syria in the 1990s.

Strategic alliances between Damascus and the PKK, KDP and PUK served to create tensions between these three competing parties. Furthermore, the collaboration of these parties with the "Syrian state," which is deemed an "enemy" for the Syrian Kurds, resulted in friction with the KDPS. The fact that the leaders of the PKK, KDP and PUK downplayed the problems of the Syrian Kurds because of the pressure from the Syrian "boss" was largely seen as a betrayal of the pan-Kurdish doctrine. Nevertheless, while using the Kurdish movement against Iraq and Turkey, Hafiz Al-Assad ironically contributed greatly to the consolidation of Kurdish transnational politics by encouraging the strengthening of cross-border relations between the Syrian Kurds and the Kurds of

\footnotetext{
${ }^{280}$ Tejel explains the concept of dissimulation as follows: "This sociological concept means that under certain adverse sociopolitical conditions actors disguise their differences or distinguishing traits in order to challenge the official unanimist ideology at its deepest roots. But when conditions permitted, the formerly hidden group ceases to play this game of conformity and insists on being visible and exposing their differences." Tejel. 83-84.
} 
Turkey and Iraq. This led to a revival of Kurdish identity and empowerment of panKurdish ideal in Syria by "proxy."

As the Syrian Kurdish parties were unable to establish themselves as a significant political opposition in the country, the political and cultural activities of the better organized and stronger Kurdish groups of Iraq and Turkey helped Kurdish politics in Syria maintain a certain level of organizational capacity. It was notably the activities of the PKK that played a significant role in providing the Kurdish culture with greater visibility in the Syrian public sphere. The implications of this process were manifested particularly through the establishment of the Democratic Union Party (PYD) by the sympathizers of the PKK in Syria in 2003, which became the most influential Kurdish party in Syria.

\section{Reawakening of Kurdish Nationalism in Syria}

During the 1980s and 1990s, the position of the Kurds in Syria can be categorized into three groups: Those who were responsive to Hafiz Al-Assad's policy of cooptation, namely, the Kurdish "clients" of the regime; the small partisan groups, which were mostly the splinters of the KPDS; and finally, those who joined the ranks of the Iraqi Kurdish parties or the PKK as a way to remain politically mobilized and express their Kurdish identity. Joining the Kurdish movements in Turkey and Iraq was very appealing for the majority of the Syrian Kurds within the framework of pan-Kurdish aims, while as Kurds of Syria, they remained mostly silent on Syrian issues. The small partisan groups largely opted for a policy of dissimulation, which was based on a refusal to submit to official repression while avoiding an open confrontation with the regime. By the 1990s, it was these groups that eventually broke away from the game of conformity and provided 
the Kurdish movement in Syria with a vocal wing to challenge the Arabist ideology of the regime through greater visibility.

Before the events of Qamishli, which took the Syrian authorities by surprise in March 2004, there was already a steady increase in Kurdish activism and outspokenness in Syria that had started in the 1990s. Periodic protests and confrontations were taking place, particularly on significant days such as Newroz (the Kurdish new year) or the anniversary of the 1962 census. The effort to raise the visibility of the Kurdish movement's demands was further intensified after the establishment of the Yekîtî Party in 1992, which was created by Kurdish partisan groups of diverse origins including the proponents of a Marxist ideology and Kurdish nationalism. Coming from the leftist strand that was primarily affected by the ideological debates of the Cold War, the Yekiti sought to draw youth into its ranks by focusing on the broader discourse of empowerment of civil society and respect for human rights, as well as the key events in "ethnic" memory, particularly the creation of Kurdish autonomy in northern Iraq in 1992.

As a clear indication of the collapse of the strategy of dissimulation, the Yekiti introduced a new repertoire of actions aimed at more "visibility" including publications, campaigning, protesting, demonstrations, and striking. Compared to the fairly modest demands of Kurdish parties in Syria in previous years, which were confined largely to cultural matters with no mention of self-government or regime change, the Yekiti adopted a more radical program. During the third party congress in November 1999, territorial demands, referencing a "Syrian Kurdistan" were incorporated into the Yekiti 
program. ${ }^{281}$ On the Kurdish issue, the party advocated for the constitutional recognition of the existence of the Kurdish people. On a political level, the Yekiti stressed the need for a decentralized political system that would take into account the democratic balance between all the components of the Syrian society and demanded the Kurdish people manage themselves in their legislative, administrative and judicial matters in the Kurdish majority areas within the framework of a democratic parliamentary system. ${ }^{282}$

The end of the strategic alliance between Damascus and the PKK after the expulsion of the PKK leader, Abdullah Öcalan, in 1998, further increased the influence of the Yekiti on the Kurdish political scene in Syria. Although the capture of Öcalan and its effects on the PKK dealt a major blow to the Kurdish cause in general, the elimination of the PKK's presence in Syria lent a more autonomous character to the Syrian Kurdish movement. As the PKK plunged into a crisis of reorganization after Öcalan's arrest, the Yekiti aspired to fill the void left by the PKK. The Yekiti organized several large and bold human rights demonstrations in Damascus and Aleppo during the early 2000s. In the meantime, dramatic changes were taking place in the Syrian political arena after the death of Hafiz Al-Assad, which gave further impetus to Kurdish political activity.

\section{Towards the Qamishli Revolt}

By the early 2000s, there were two important developments that had major impacts on Kurdish politics in Syria: in the domestic field, a period of intense political and intellectual debate started to take place in after the death of Hafiz Al-Assad, which

\footnotetext{
281 Tejel, 112.

282 The Yekiti party program amended and approved by the Sixth Conference in December 2009 is available online at http://yekiti-media.org/nuce.php? $\mathrm{z}=\& \mathrm{id}=33 \& \mathrm{z}=\mathrm{en}$ (Accessed February 8, 2013).
} 
raised hopes for democratic change in Syria. At the regional level, the fall of Saddam Hussein in Iraq in 2003, and the subsequent gains made by the Iraqi Kurds provided the Syrian Kurds with encouragement to take a more active stance in demanding their cultural and political rights in Syria. As a result of these events, the stage of "visibility" that had been in the making on the Syrian Kurdish political scene over the past decade gained further momentum and consolidated the status of the Kurdish element in the opposition movement.

Bashar Al-Assad's takeover in 2000 raised hopes for change in Syria and it initiated a civil society movement known as the "Damascus Spring," which made many people believe that young Assad might open up the country. From June 2000 to August 2001, Syria's long silenced civil society took advantage of this changed atmosphere to call for a democratic opening. Numerous discussion circles, debates, forums, and assemblies were formed all over the country with the purpose of addressing once taboo topics as political, economic and human rights reform, corruption, political prisoners and exiles, and the development of an autonomous civil society in Syria.

In September 2000, leading intellectuals signed the "Manifesto of the 99," which called for the repeal of the state of emergency and the emergency laws of 1963, the release of all political prisoners, the return of Syrians from exile, and freedoms of speech and press. ${ }^{283}$ It was followed by the "Manifesto of the 1,000" in January 2001, in which the demands for electoral reform and abolition of one-party rule were emphasized. Finally, in May 2001, the Syrian Muslim Brotherhood published a National Charter from

\footnotetext{
${ }^{283}$ KurdWatch (2009). "The Kurdish Policy of the Syrian Government and the Development of the Kurdish Movement since 1920”, Report 1, 17.
} 
exile in London calling for a modern, democratic Syria and the rejection of any form of political violence. ${ }^{284}$ The Kurdish parties and activists also took part in the Damascus Spring and made contacts with the Syrian opposition. The softening of the government's approach to the Kurdish movement allowed the Kurdish political organizations to meet more openly and increase their activity.

The regime's initial reaction to the public demand for democratic change was encouraging. Hundreds of political prisoners, including the communists and members of Muslim Brothers, were released, and several of the prisons notorious for the brutal treatment of inmates were shut down. ${ }^{285}$ However, the democratization drive came to a rapid halt in February 2001, when the Baath party started accusing activists of weakening and discrediting state institutions, and harming the stability and unity of Syria. Civil forums were declared illegal and terminated, and pioneers of the civil society movement and other prominent human rights activists were arrested. The government tightened censorship and issued new guidelines on publications that restricted the ownership of periodical publications to Syrian Arabs, suggesting that members of the Kurdish minority and stateless Kurds born in Syria were excluded. ${ }^{286}$

Although Bashar Al-Assad's regime initially adopted a reconciliatory attitude and made positive public statements in an attempt to subdue the demands for political change, it soon became apparent the government was not willing to undertake any real change.

\footnotetext{
${ }^{284}$ See Al-Hayat, May 4, 2001, quoted in International Crisis Group, "Syria Under Bashar: Domestic Policy Changes", February 11, 2004, 7.

${ }^{285}$ Ibid.

${ }^{286}$ Human Rights Watch (2002). Human Rights Watch World Report 2002, 468.
} 
Nonetheless, despite the end of Damascus Spring and the closed political context, between 2002 and 2004, Kurdish political actions in Syria in the form of demonstrations and protests increased dramatically in both frequency and scale. The fact that the return of suppression after the Damascus Spring was followed by a constant cycle of Kurdish protests clearly indicated a new level of confidence among the Kurds in Syria.

The most important aspect of Kurdish activism in this period was that increased international attention on human rights reflected positively on the actions of the Kurds who started to frame their dispute with the state specifically in human rights terms. As the leading actor in organizing the protests, the Yekiti played a crucial role during this process and strengthened its position in the Kurdish movement. On December 10, 2002, International Human Rights Day, approximately one hundred and fifty members of the Yekiti demonstrated in front of the Syrian Parliament, shouting demands for citizenship cultural rights for the Kurds as well as respect for human rights in Syria. The signs carried during the demonstration read "Syria is the country of all, be they Arab or Kurd," "We demand that the Syrian constitution recognize Kurds as the second official ethnicity of the country" and "We demand a definitive solution to the Kurdish question in the framework of national unity."287

The gathering of December 10, 2002, was certainly not the first public demonstration organized by the Kurds, but it was unique in many ways. First, the discourse of the protest was quite assertive in spite of the severely restricted political space in Syria. The demonstrators posed a direct challenge to the official ideology of the

\footnotetext{
${ }^{287}$ Gauthier, Julie (2009), “The 2004 Events in al-Qamishli: Has the Kurdish Question Erupted in Syria?" in Demystifying Syria edited by Fred H. Lawson, London: Saqi Books.
} 
Baathists by referring to the universal values against injustice and discrimination. Second, through the messages on the placards, the ideology of the regime was torn apart in the street, a space that had long been confiscated and manipulated by the state for its own glorification. ${ }^{288}$ Third, the demonstration indicated the Kurdish movement in Syria had managed to overcome its impotency and had revived the peaceful and democratic struggle it had long advocated. Finally, the gathering was a message to both those in power and the broader opposition in Syria that the Kurds' capacity for action can no longer be underestimated.

Yekiti's strategy of greater visibility and the subsequent arrest of two Kurdish leaders led to disputes with other parties in the Syrian-Kurdish party spectrum that argued further confrontation with the government could be damaging. Nevertheless, despite the arrests and repression, demonstrations and public actions organized by the Yekiti increasingly continued in 2003 and 2004.

On June 25, 2003, Yekiti organized a "parade of children" in front of the UNICEF building in Damascus, on the occasion of the World Children's Day. Once again, a symbolic date was chosen as part of Yekiti's strategy to associate Kurdish demands with universal issues. The banners were asking for freedom of cultural expression and language, particularly the right to teach in Kurdish language. This time, Yekiti did not find itself alone as other Kurdish parties agreed to participate. Broader participation was achieved on October 6, 2003, when Yekiti agreed to avoid overtly politicized messages and participate in a silent demonstration with other Kurdish parties to commemorate the census of 1962. Although, it was a retreat from the Yekiti's offensive strategy, the ${ }^{288}$ Ibid. 
demonstration not only provided greater collaboration among the Kurdish parties but also made it possible, for the first time, for the Kurds and the Arab opposition as well as certain human rights organizations to act in concert in Syria.

This cooperation further solidified on December 10, 2003, International Human Rights Day. The demonstration showed how dramatically things had changed in the one year after the December 2002 demonstration. Yekiti had broken its isolation and managed to obtain the support of a number of groups from both the Kurdish and Arab opposition. The number of participants in the December 2003 demonstration increased remarkably involving around a thousand people in front of the Syrian Parliament.

In late 2003 and early 2004, a number of demonstrations took place outside court buildings in protest of the trials of political detainees, Kurdish and other. In February 2004, the release of the Yekiti leaders, Marwan Usman and Hasan Salih, who were arrested after the December 2002 demonstration, mobilized 15,000 people who gave them a triumphant welcome to the city of al-Qamishli. ${ }^{289}$ On March 8, 2004, a counterdemonstration was organized by the Kurdish and Arab parties in front of the Syrian Parliament in Damascus on the anniversary of the 1963 revolution through which the Baath Party had come to power. The same day, large crowds of Kurds spontaneously appeared in the streets in the majority of Kurdish towns to celebrate the recognition of federalism in Iraq. Another large gathering on March 8, 2004 took place in al-Qamishli to celebrate International Women's Day. Despite the inclusive title, the celebration was used mainly as a "pretext" to affirm Kurdish identity in the public sphere.

\footnotetext{
${ }^{289}$ Ibid.
} 
The regularity of the demonstrations, the choice of symbolic dates associated with universal human rights, and the diversity of the actors involved - students, human rights associations, Kurdish and Arab parties - made the protests between 2002 and 2004 an undeniably new phenomenon in Syria. They represent not only the rapidly developing organizational capacity of democratic forces in Syria, but also the growing influence of the Kurds in the larger opposition movement. The security forces' repression continued against the Kurdish leaders as well as other activists, with increased numbers of people taken into custody after each action. Four days after the events of March 8, the Qamishli Revolt erupted, which intensified the Kurdish struggle against the state and opened another chapter in the process of democratization in Syria.

\section{The Beginning of a New Era: The Qamishli Revolt}

If the period between 2002 and 2004 showed the potential of the Kurdish movement to become an active member of the opposition movement in Syria, the Qamishli revolt and the events that unfolded in its aftermath represented the transformation of this potential into a substantial political force. On March 12, 2004, the protest movement of the previous two years took a different turn after unrest at a soccer match in al-Qamishli resulted in six dead, all Kurds. This situation quickly led to the ethnicization of the incident. The outrage over the death of six Kurds was transformed into Kurdish nationalist rallies during the demonstrations and funeral marches on March 13. A series of protests and violent incidents took place in Kurdish areas across Syria, including in other Kurdish towns in Jazira and further afield to Kobani, Aleppo, Afrin 
and Damascus. ${ }^{290}$ Massive clashes occurred between protesters and the security forces. More than thirty people were killed, several hundred injured, and roughly two thousand people were detained and exposed to ill treatment. ${ }^{291}$

It was particularly the young Kurds who took part in protests in large numbers. Grown up largely with ethnic discrimination and economic marginalization, they interpreted the events of March 12 as the state's attack on the Kurdish community and reacted with nationalist symbols. The regularity of arrests and torture between 2002 and 2004, had already reinforced solidarity among the Kurds in Syria and fueled Kurdish dissent against the state.

The nationalist charge of the situation was intensified by the political developments in Iraq, which had an undeniable impact on the events in Qamishli. The Iraqi Transitional Administrative Law, which secured the autonomous status of the Kurdistan region of Iraq, was signed on March 8, 2012. This development had its own dynamic in Syria, both among the Kurds and within the government. While the change of circumstances in Iraq was a major inspiration for the Syrian Kurds, for the Syrian government, events in Iraq created the fear of a domino effect. The mass demonstrations in Qamishli and other cities confirmed this fear. Accordingly, the reaction of the Syrian state against the demonstrators was considerably harsh and the number of those killed or arrested was unparalleled in comparison to earlier events. ${ }^{292}$

\footnotetext{
${ }^{290}$ Lowe, Robert (2010). "The Serhildan and the Kurdish National Story in Syria," in The Kurdish Policy Imperative edited by Robert Lowe, Garteh Stansfield, London: Royal Institute of International Affairs. 169.

${ }^{291}$ Amnesty International. "Kurds in the Syrian Arab Republic One Year after the March 2004 Events," March 10, 2005, 11-18.

${ }^{292}$ KurdWatch (December 2009). "The Al-Qamishli Uprising: The Beginning of a New Era for Syrian Kurds", Report 4, 3.
} 
As far as the scale of protests, the numbers involved, and the extent of the casualties, the Qamishli revolt was minor compared to Kurdish unrest in Turkey, Iran, and Iraq, but for Kurds in Syria, it was a momentous event. Qamishli not only redefined the Kurdish question in Syria, but also transformed the status quo between the Kurds and the Syrian government. Demonstrations of this magnitude had never before occurred in the history of the Kurds in Syria and the Syrian state faced the greatest popular challenge to its authority since the insurrection of the Islamic opposition led by the Muslim Brotherhood in 1982. For the first time, the protest movement united all the Kurdish parties and involved all the Kurdish territories in the country as well as the major Syrian cities with significant Kurdish populations, such as Damascus and Aleppo. This gave a powerful new expression to the existence of Kurds in Syria and underscored the symbolic unity of the Kurdish Syrian space. A Kurdish militant based in Germany clarified the importance of the events of March 2004, by stating, "the intifada of March delineated the map of Syrian Kurdistan."293

It is important to emphasize the popular and spontaneous nature of the uprising; Kurdish parties were certainly not the driving force behind the unrest. The demonstrations represented a genuinely popular expression of discontent and increased confidence in the public expression of Kurdish identity. At no other point in time was the Kurdish community's potential to mobilize as high as it was in March 2004. However, instead of seizing the occasion to strengthen their ranks and create greater unity, the Kurdish parties chose to pacify the street in the immediate aftermath of the regime's crackdown. Thus, the events in 2004 did not lead to political concessions by the

${ }^{293}$ Gauthier, 113. 
government. In June 2005, however, when mass rallies were held yet again, the approach of the Kurdish parties was different. Containing the riots was no longer the strategy in 2005 , although, opinions differed greatly on how to deal with the regime's ban on demonstrations. A split in the party spectrum gave way to the emergence of a passive wing known as the "moderates" and a more active wing known as the "radicals," which advocated for a more open confrontation with the state.

The split among the Kurdish parties was already evident in the late 1990s after the establishment of the Yekiti and the reorganization of the PKK in Syria. The collaboration between the PKK and the Syrian regime came to an end in 1999, following the Syrian government's decision to hand over Öcalan. The PYD was established in Syria in 2003, which immediately joined the ranks of the radical wing. Besides the Yekiti and PYD, the Azadi and the Future Movement, emerged as a result of the events in 2004, were the other members of the active wing.

The split within the Kurdish party landscape was well suited to the regime's traditional "divide and rule" policy, which was based on favoring one section of the Kurdish opposition while persecuting others. However, although the lines separating the "moderates" from the "radicals" hardened in 2005, the potential for a unified Kurdish movement in Syria had never been more present. The regime tried to prevent unified Kurdish action by favoring relations with the official representatives of the moderates to the detriment of the radicals. Nevertheless, it was apparent by 2005 that the traditional cooptation policy towards the Kurds in Syria was no longer a sustainable strategy to contain the Kurdish movement in the long term. 
Another significant impact of the Qamishli revolt was that it gave rise to a previously unknown degree of solidarity, not only among the Syrian Kurds but also between the Syrian Kurds, the Iraqi-Kurdish, and the Turkish-Kurdish populations. Traditionally, it had been the Syrian Kurds who were engaged in the national movements of Kurds in neighboring countries. The Kurds of Syria not only held demonstrations to express concern over events that took place in Iraqi and Turkish Kurdistan such as the poison gas attack on Halabja and the arrest of Öcalan, but had also joined the armed movements of the Kurds in Turkey and Iraq. During March 2004, countless Iraqi and Turkish Kurds in the European diaspora, as well as in Diyarbakir (Turkey), Erbil, Dohuk, Sulaymaniyah (Iraq) demonstrated to show solidarity with the Syrian Kurds. ${ }^{294}$ The events of Qamishli not only reaffirmed Kurdish identity as a transnational phenomenon, but also legitimized the autonomous character of the Kurdish movement in Syria and reinforced the sense of "Syrian Kurdishness."

\section{Evolving Relations between the Kurdish and Arab Opposition}

The demonstrations of March 2004 made the Kurdish capacity for mobilization acutely apparent to the Syrian opposition. The fact that a certain ethnic group was able to appear on the streets in such large numbers in defiance of the authorities was remarkable to other ethnic, religious and political groups in the country. The impact of the Qamishli revolt on the relations between the Arab and Kurdish opposition movements was twofold: first, the size of the Qamishli revolt forced Arab activists to recognize the Kurds constitute a political force in Syria that could no longer be ignored, and second, the growing Arab-Kurdish cooperation emerged in the wake of the Qamishli revolt ironically

\footnotetext{
${ }^{294}$ KurdWatch, Report 4, 3.
} 
crystallized the striking differences between Kurdish and Arab opposition groups' vision of a democratic Syria.

There had been certain level of cooperation between the Kurdish and Arab opposition groups since the Damascus Spring. However, prior to the events of Qamishli, the Kurdish issue had been largely ignored by the Arab opposition because of the perceptions regarding Kurdish secessionist aims. The events of March 2004 significantly brought the Kurdish question to the attention of Syrian opposition and led to increased contact between Arab and Kurdish leaders. Opposition groups issued a statement of unity and democratic change known as the Damascus Declaration in October 2005, which marked the official recognition of Kurdish opposition as a powerful political force in Syria. The document was signed by a large number of opposition figures and parties, including both secular and religious, Arab and Kurdish. The Declaration was an important initiative particularly because it included the Muslim Brotherhood, which was the most powerful Sunni-based Islamic opposition group in Syria. Furthermore, it was the first time the Muslim Brotherhood had publicly acknowledged the legitimacy of Kurdish grievances. The statement included an explicit reference to the status of the Kurds in Syria. The signatories declared that they were committed to:

Find a just democratic solution to the Kurdish issue in Syria, in a manner that guarantees the complete equality of Syrian Kurdish citizens with the other citizens, with regard to nationality rights, culture, learning the national language, and the other constitutional, political, social, and legal rights on the basis of the unity of the Syrian land and people. Nationality and citizenship rights must be restored to those who have been deprived of them, and the file must be completely settled. ${ }^{295}$

\footnotetext{
295 The English version of the complete text is accessible at http://www.demdigest.net/damascusdeclaration.html (Accessed October 28, 2012).
} 
However, despite the increased consciousness of Kurdish groups by the Arab opposition, cooperation remained limited because of the transformation of the Syrian Kurdish movement into a popular struggle. As the size of the Qamishli revolt conspicuously transcended the boundaries of Kurdish partisanship and underscored the mass base of the Kurdish movement in Syria, increased emphasis on the "identity" theme in the articulation of Kurdish demands radicalized the politicized ethnic divides in the country. Although the Damascus Declaration was an important step in terms of inserting the "Kurdish question" into the Arab opposition's agenda, striking differences between the opinions of Kurds and Arabs regarding democratic transformation in Syria and the solution to the Kurdish problem soon became apparent.

First, the limited Kurdish-Arab cooperation that took place in the aftermath of the Qamishli revolt soon fell victim to the mutual suspicions that had long been cultivated by the regime. The strongest opposition to the Baath regime during the 1970s and 1980s was the Sunni-based Islamic political groups, among which the Muslim Brotherhood was the most prominent. The Islamic insurgency that grew by the mid-1970s was eventually crushed by the bloody Hama massacre of 1982, in which thousands were killed including civilians. The Hama incident generally marked the defeat of the Islamic opposition movement led by the Muslim Brotherhood in Syria.

The relations between the Kurds and the Syrian government at the time were generally defined by Hafez Al-Assad's policy of alliance with the civil and religious Kurdish elites in order to keep the Kurdish nationalist movement in Syria in check and contain the Islamist threat in Syria. Collaboration with various Kurdish groups was strategically important for Hafez Al-Assad in order to maintain the stability of the regime 
as the Sunni affiliation of the majority of the Kurds helped him tone down the Sunni opposition's challenge to the regime's legitimacy. A major implication of this arrangement was that the Arab Sunni majority regarded the Kurds as partners of the regime. Moreover, having identified themselves as secularist parties characterized mainly by a tendency toward Marxist and socialist discourse, Kurdish parties in Syria never embraced the Islamic doctrine, which always put them at odds with the Islamist movement.

As second, Arab-Kurdish distinction was tied to the sudden outburst of Kurdish nationalism in 2004 that coincided with increasing U.S. and Israeli pressure on Syria as well as the fall of Saddam Hussein's regime in Iraq, creating a great deal of suspicion among the Arab nationalists who had shown support towards the Kurdish plight during the 2002-2004 protest movement. During the demonstrations of March 2004, there were explicit Iraqi-Kurdish references. The slogans "Free Kurdistan" and the use of nationalist symbols such as the Kurdish flag highlighted the territorial nature of Kurdish claims in Syria. The fact the demonstrators carried portraits of Iraqi-Kurdish leaders Masoud Barzani and Celal Talabani as well as of Abdullah Öcalan, suggested the Qamishli revolt represented the Syrian Kurds' solidarity with the Kurdish movements in Turkey and Iraq. Furthermore, through the demonstrators' references to the Iraqi government's poison gas attack on the Iraqi-Kurdish city of Halabja in 1988, a direct parallel was drawn between the suffering of the Iraqi Kurds in Halabja and that of the Kurds in Syria in al-Qamishli.

The references to the Iraqi-Kurdish experience played directly into the regime's hands. The extremely violent repression of demonstrations risked fueling Kurdish nationalist sentiments and contradicted the Syrian regime's traditional policy of 
cooperation with certain groups and individuals in the Kurdish community. This renewed assault on the Kurds was mainly a result of the changing dynamics of the Kurdish question at the regional level and concerns over the regime's internal legitimacy. Hence, it would be pertinent to interpret the regime's violent crackdown on the Kurds both as an indication of the Syrian authorities' concern over the growing American presence in the region, and as a response to the growing cooperation between the Kurds and Arabs after the Damascus Spring. This perspective suggests the regime intended to profit from the events in Qamishli by creating a schism between Arabs and Kurds in order to tighten the Arab ranks in defense of the regime and reorient the Sunni opposition towards Islamic/pan-Arab solidarity. ${ }^{296}$

The Assad government exploited the military and political events in Iraq after 2003 in order to "kill two birds with one stone." On the one hand, playing on the Arab concerns for Kurdish secessionism, the regime justified the violent dispersal of demonstrations by promoting the importance of preserving Syrian national unity. The emergence of a more aggressive Kurdish strategy towards the government and parallels drawn by the Syrian Kurds between the fall of Saddam Hussein and a possible fall of Bashar Al-Assad were used by the regime to accuse against the Kurdish parties of seeking U.S. intervention in Syria comparable to that in Iraq. The regime and official media established explicit parallels between the riots of Qamishli and the deteriorating public order in Iraq, playing on the fear that Syria would plunge into a similar situation of ethnic and religious violence after a foreign intervention. ${ }^{297}$

\footnotetext{
${ }^{296}$ Gauthier, 115.

297 Tejel, 130.
} 
On the other hand, playing on the secularists' concern of a possible rise of Islamism in Syria, the regime presented itself as the only solution to safeguard Syria from falling into the same sectarian violence and chaos as experienced in Iraq. This argument particularly resonated with some secularist Kurds who opposed the rise of an Islamic power in Syria and an increase in the Sunni Arab majority in politics, to the detriment of ethnic and religious minorities. Despite their strong distrust of the Baath regime, for the majority of the Syrian Kurds, Bashar Al-Assad was a more preferable enemy than a regime dominated by the Muslim Brotherhood.

The primary fear behind the regime's efforts to fracture the opposition was the potential for cooperation between the Kurds and the Muslim Brotherhood, the two largest opposition groups in Syria. It was believed that the Syrian opposition's ability to pose a real challenge to the regime was, to a large extent, contingent upon a compromise between the nationalist doctrine of the Kurds and the Muslim Brotherhood's Islamic doctrine. Although the Damascus Declaration of October 2005 was a significant step for the Syrian opposition to surmount the mutual suspicions defined along the lines of religious-secular and Arab-Kurd, the regime's strategy played on certain ethnic- and religiously-based fears in the Syrian society and took its toll on the nascent Arab-Kurdish cooperation that emerged following the Qamishli revolt. The radical wing composed of the Yekiti, Azadi, Future Movement and the PYD, despite praising the Damascus Declaration's demands for democratic change, did not sign the text due to their reservations regarding the absence of a passage referring to the explicit recognition of the 
Kurds as an independent national group with historic ties to the land along with the Arabs in Syria. ${ }^{298}$

The Damascus Declaration proposed no clear solution to the Kurdish problem other than emphasizing it had to be resolved within a democratic and inclusive framework. Furthermore, the text's special reference to Syria's affiliation to Arab order was decried by some of the Kurdish groups as evidence of unceasing Arab chauvinism. ${ }^{299}$ The territorial demands of the Kurds were seen unacceptable, particularly to the Muslim Brotherhood, which rejected every autonomist plan for the Kurds and insisted on the general rhetoric of democratization in Syria and equality for all citizens as a solution to the Kurdish question.

The fundamental problem was that while the majority of the Syrian opposition was confining the Kurdish question to the single issue of nationality rights and the return of citizenship to the stateless, the Yekiti and PYD and their allies were demanding the recognition of the Kurds as a separate nation and acceptance of the principle of administrative decentralization in Syria. After the launch of the Damascus Declaration, despite conciliatory declarations by the Muslim Brotherhood leadership concerning the cultural demands of the Kurds, there was widespread distrust among certain Kurdish parties upon seeing the reemergence of the Muslim Brotherhood as an organized force inside Syria.

\footnotetext{
${ }^{298}$ KurdWatch Report 1, 20.

${ }^{299}$ Pace, Joe, Landis, Joshua (2009). "The Syrian Opposition: The Struggle for Unity and Relevance, 20032008" in Demystifying Syria edited by Fred H. Lawson, London: Saqi Books.
} 
The radicalization of ethnic divides in Syria after the events of Qamishli as well as the fracture between the Kurdish parties and the rest of the Syrian opposition during the negotiation process of the Damascus Declaration made it acutely apparent that the basis of the problem was in the concept of the nation state. The radical wing of the Kurdish parties attempted to place their actions and demands under a more universal human rights framework with an emphasis on administrative decentralization in Syria. In other words, Kurdish cultural, political, social and legal rights and demands for complete equality of Syrian Kurds with the other citizens were linked directly to the demands for the recognition of the Kurds as a separate nation with their historic ties to the Kurdish lands in Syria. However, according to the majority of Syrian parties and human rights associations in the opposition, the Kurds, rather than constituting a separate nation, were ordinary Syrian citizens who had been deprived of some of their rights. Recognition of the Kurds as a separate nation would mean the official recognition of Syria as a multinational country, which, in the minds of the Syrian opposition figures, was not compatible with the idea of "national unity" required by the concept of nation state. Accordingly, rather than a principle of democracy, administrative decentralization was seen primarily in the context of the "hidden objectives" of certain Kurdish parties, notably the radicals.

As the wave of mass demonstrations and protests of the revolt of Qamishli cooled down at the end of 2005 , the Syrian political arena consisted of three main forces. The first, Bashar Al-Assad, imposed a large-scale crackdown on all opposition groups in Syria and managed to stabilize the regime in the international arena by 2006 . Departing from the Bush administration's policy of sanctions and lumping Syria together with Iran, 
Barack Obama adopted a new policy of engagement with Syria after he took office in 2009. This shift in American policy towards Syria helped Assad reduce its international isolation. Regarding the relations between the Kurds and the Syrian regime, Bashar AlAssad took note of this new era marked by a strong public display of the "Kurdish problem" in the Syrian political sphere. In his attempt at defusing the Kurdish unrest and international human rights criticisms, the Syrian government publicly raised the issue of the 1962 census and the problem of statelessness for the Syrian Kurds for the first time. Nonetheless, these occasional gestures and statements contradicted the government's policies, which, since 2004, have squeezed the political and cultural space available to the Kurds. ${ }^{300}$ The regime continued to favor relations with certain parties as official representatives of the Kurds, while increasing arrests and persecutions for others, most notably the Yekiti and the PYD, on grounds they sought to undermine the unity of the state through sectarianism.

The Syrian opposition, which is the second of the three major political forces in Syria, established a broad-based alliance as a result of the social and political mobilization provoked by the Kurdish parties between 2002 and 2005. For the first time in decades, Syria's bickering political parties, outspoken intellectuals, and civil society groupings came together, Kurdish and Arab nationalists found common ground, and socialists, communists, liberals and Islamists showed a willingness to unite over a single platform of democratic change and respect for another. ${ }^{301}$ The most crucial aspect of the Damascus Declaration was the fact that the Muslim Brotherhood and the secular groups

\footnotetext{
${ }^{300}$ Lowe (2010). 176.

${ }^{301}$ Pace, Landis, 126.
} 
were finally able to set aside their mutual suspicions and collaborate with the shared goal of democratic transformation in Syria. Nevertheless, while the secular and Islamist camps in the opposition managed to mitigate popular suspicions against each other, each camp continued to maintain its strong opposition to certain "identity" demands by the Kurds. Although the Syrian opposition, for its part, established ties with the Kurdish parties following the events of Qamishli, their refusal to look at the "Kurdish problem" beyond the nation state framework persisted.

In the wake of the Qamishli uprising, the Kurdish movement in Syria emerged as the "third force" within the movement for change in the country. The oppositional coalition formed by the Damascus Declaration set off alarm bells for the regime, particularly in terms of the reinstatement of an Islamist presence in the public sphere in Syria. Given the fact that the fundamental ideological principle of the Baathist regime was Arab nationalism, the striking rise of the Kurds within the opposition raised an even greater concern for the preservation of the last remaining pillar of the regime's ideological legitimacy. The Syrian opposition shared the Kurdish goal of advancing democracy in Syria, all the while maintaining their strong opposition to the recognition of the Kurds as a separate nation and their demands for decentralization. Although the radical wing of the Kurdish movement strived to place its actions in a more universal framework, emphasized human rights and peaceful coexistence of different nationalities, the identity theme embedded in the demands resulted in the exclusion of the movement by both the regime and the opposition.

After the events of Qamishli, a new equilibrium was put into place between not only the Kurds and the regime, but also the Kurds and the Syrian opposition. For the 
regime, Kurdish national identity was no longer the marginal political question that could be dealt with through the traditional cooptation policy. As for the opposition, the Kurdish movement became a major political force that constantly pushes the boundaries of the discourse of human rights and democratization promoted by the Muslim Brotherhood and other Arab opposition figures. Hence, accommodation with the Kurds in Syria became largely contingent on the capacity of both the regime and the opposition to meet the economic, political and cultural expectations of the Kurdish movement. While the question of how the aspirations of those politicized and radical Kurds would evolve remained on hold during the years following the Qamishli revolt, the spread of the Arab uprisings to Syria in 2011 opened a new chapter in the complex relationships among the Kurds, the Assad regime, and the Syrian opposition. The Kurdish movement, once again, emerged as a crucial player whose political leverage became critically important in tipping the scales of the emerging political instability.

\section{Syria: The Arab Spring's Final Destination}

When a series of pro-democracy uprisings hit the Arab world in late 2010, Bashar Al-Assad was confident that the spread of ongoing protests in other Arab countries to Syria was unlikely. Assad's belief in the stability of Syria was derived primarily from his contention that the state was aligned with its people in terms of its foreign policy. ${ }^{302}$ Assad's argument was based mainly on Syria's defiance towards the U.S, and support for the Palestinian and Lebanese resistance movements, which have long been the primary tools of the regime to maintain its legitimacy in the eyes of the Syrian people. However,

302 Interview with Syrian President Bashar al-Assad, The Wall Street Journal, January 31, 2011, http://online.wsj.com/article/SB10001424052748703833204576114712441122894.html (Accessed April 27, 2011). 
the other side of the coin, the domestic field, had been marked by sporadic social unrest and demands for reform towards democracy and open government since the Damascus Spring. The protests that started in Syria in March 2011, eventually proved Assad wrong and Syria became the last Arab country to join the wave of uprisings sweeping across the Middle East.

The Kurds have been active in the protests since the beginning of the uprising. There has been a large-scale mobilization, particularly among the Kurdish youth, in the form of street demonstrations. However, it is important to distinguish those activities from the official stance of the Kurdish parties in Syria, which largely avoided voicing open support for the Syrian opposition. The fact that the party-based Kurdish opposition maintained a low profile throughout the uprising did not derive from a reluctance to support regime change. Rather, it needs to be viewed more as a continuation of with the Kurdish position to act as a "third force" in the movement for change in Syria.

Anti-regime sentiment is deeply rooted among the Kurds in Syria given the discriminatory policies of Syrian Arab Baathism throughout the twentieth century. Furthermore, the Kurds have clearly shown they would not refrain from confronting the regime and resisting its oppressive policies after 2004. However, as Syria's conflict expanded, and many young Kurds joined the calls for the downfall of the regime, skepticism grew among the Kurdish parties that the Arab-dominated Sunni opposition lacked the inclusive vision necessary to satisfy the various minority groups in Syria. Hence, contesting the opposition's "anti-regime" rhetoric, the Kurdish response to the uprising was marked more by an "anti-systemic" stance, which was based on challenging 
both the regime and the Arab opposition on their exclusionary policies and insistence upon a particularist identity in Syria.

As the Kurds opted to remain on the sidelines of the Syrian uprising, their mode of participation in the ongoing upheaval was shaped by a complex set of factors including the Kurds' representation on the Syrian National Council (SNC) and National Coordination Body (NCB), the two main opposition coalitions established after the outbreak of the protests; the formation of a third body, the Syrian Kurdish National Council (KNC); the role of the PYD, which was facing alleged claims for getting support from the Assad regime; and the role of Turkey.

\section{The Kurds and the Syrian Opposition in the Wake of the Syrian Uprising}

Efforts to incorporate the Kurds into a unified opposition in Syria were problematic from the beginning of the uprising. The Kurds' skepticism approach of the opposition stemmed mainly from the predominantly Arab nationalist and Islamist ideology put forth by the opposition as well as its dependence on the sponsorship of Turkey whose inability to solve its own Kurdish problem was worrisome for many Kurds in Syria.

The Kurds attended successive meetings held by the opposition in Turkey and Brussels after the outbreak of the protests, which resulted in the establishment of Syrian National Council (SNC) in October 2011, an opposition coalition composed mostly of exiles. However, despite the shared goal of overthrowing the Assad regime, it quickly became evident the Kurdish and Arab opposition groups had largely differing visions of Syria's future. The Kurds were estranged immediately after the establishment of the SNC when the Arab opposition groups and the Kurdish parties remained sharply at odds over 
Kurdish demands for recognition as a distinct people within Syria, with their own cultural and linguistic rights under some form of "political decentralization." ${ }^{103}$ In the "Mission and Program" of the SNC, the opposition's vision for post-Assad Syria was described as:

The new Syria is a democratic, pluralistic, and civil state; a parliamentary republic with sovereignty of the people based on the principles of equal citizenship with separation of powers, smooth transfer of power, the rule of law, and the protection and guarantee of the rights of minorities. ${ }^{304}$

The SNC's political program also envisioned a transitional constitution for the post-Assad era, which included guarantees for the recognition of Kurdish identity and national rights:

The constitution guarantees national rights for the Kurdish people and a resolution to the Kurdish question in a democratic and fair manner within the framework of the unity of Syrian territory and people, as well as the exercise of rights and responsibilities of equal citizenship among all citizens. $^{305}$

Regarding the establishment of democratic rule in Syria and the solution of the Kurdish question, the SNC maintained the language of the Damascus Declaration by putting emphasis on the opposition's commitment to protect the minorities and their rights, including the Kurds, in the Syria's new constitution after the toppling of the Assad regime. ${ }^{306}$ While the SNC documents fulfilled the basic Kurdish demands for equal citizenship and an end to government discrimination, they fell short of the more

\footnotetext{
${ }^{303}$ Pollock, David, "Syria's Kurds Unite against Assad, but Not with Opposition", The Washington Institute for Near East Policy, July 31, 2012.

304 Syrian National Council Mission and Program available at http://www.syriancouncil.org/en/missionstatement.html (Accessed October 25, 2012).

${ }^{305}$ Ibid.

${ }^{306}$ Weiss, Michael, "Why Syria's Kurds Will Determine the Fate of the Revolution," The New Republic, November 16, 2011.
} 
fundamental demands for the recognition of the Kurds as a distinct "nation" in Syria and their right to self-determination according to the international conventions and agreements.

Besides the concerns over constitutional guarantees for Kurdish rights in the postAssad era, the larger factor that fueled Kurdish skepticism towards the SNC was the Council's dependence on its host nation, Turkey, and particularly its ruling Islamist Justice and Development Party. The Kurdish question was the prism through which Turkey approached the Syrian uprising because any constitutional recognition of the Kurds in Syria would have inevitable repercussions for Turkey's own Kurdish problem. Thus, the close relationship of the AKP to the Muslim Brotherhood and the prointervention stance of the SNC were alienating for most of the Kurdish parties that were concerned about the influence of a Turkish agenda aimed at marginalizing the demands of the Kurds and giving the Syrian Islamists a larger role in the opposition.

The Kurds remained wary about joining forces with the SNC anticipating they might be oppressed by a new Islamic Arab government in the post-Assad era if no powersharing guarantees were put in place. Those concerns were not unfounded. Dominated by an Arab/Islamist agenda advanced by the Muslim Brotherhood, the SNC failed to attract significant representation from the country's diverse ethnic and religious groups such as the Kurds as well as the Christians, Alawites and Druze. Furthermore, the delegates of the Council refused to change the name of the country from the "Syrian Arab Republic" to "Republic of Syria," which resulted in a walkout by almost all the Kurdish political parties at the Syrian National Salvation opposition conference held in Istanbul, Turkey, on July 16, 2011. 
The opposition, on the other hand, accused the Kurds of not adequately supporting the uprising against the Assad regime. The accusations against the Kurds were partly based on the fact that several Kurdish parties were members of the National Coordination Body for Democratic Change (NCB), an internal opposition group formed in June 2011, which was largely made up of secularist, leftist Arabs and Kurdish groups. The creation of the NCB was intended to rival the radical anti-regime line of Turkey conferences in the spring and summer of 2011, which resulted in the creation of the SNC. ${ }^{307}$ Although the NCB believed the Syrian regime had to be replaced by a democratic government, the coalition adopted a more moderate stance that encourages reform and dialogue instead of an open confrontation with the regime. The members declared they stood on the side of the revolution, yet were staunchly opposed to foreign intervention supported by pro-Western exiles. In this respect, the group's political line was generally determined by an anti-imperialist ideology and strong opposition to Western influence in the Middle East, as well as the severe security constraints facing its Syrian-based leadership.

The conservative Sunni groups, particularly the exiles, viewed the NCB's strong secularist and anti-imperialist credentials with great suspicion. The group was accused by the supporters of the SNC of "treachery" and being on the regime's side. Accordingly, the NCB remained considerably unattractive to Sunni Islamist opinion, which limited the coalition's popular outreach. Its strong secularist and anti-sectarian message encouraged

\footnotetext{
${ }^{307}$ Lund, Aron (May 2012.) "Divided They Stand: An Overview of Syria's Political Opposition Factions," Foundation for European Progressive Studies, Uppsala, Sweden, 47.
} 
more minority participation than the overtly Sunni dominated SNC, which later came under criticism on the grounds it lacked effective minority representation.

Given its moderate stance, the NCB, to a certain degree, was tolerated by the Assad government because it was in the interest of the regime to both agitate against foreign intervention and create infighting by the opposition, which was of great benefit to Assad. In addition, the government also wanted to send the message that as long as the opposition remains open to dialogue and stay clear of foreign ties, they will be able to express themselves freely. Aware of the regime's self-interested motives, the NCB, in return, maintained a pragmatic stance by taking advantage of this room to maneuver, while carefully confronting accusations of being pro-regime by avoiding any action that would confer legitimacy on the government. ${ }^{308}$

The regime's attitude towards the Kurds in the early days of the uprising emerged as another major factor that strained the relationship between the Kurds and the Arab opposition. When the uprising broke out in March 2011, fearful of the Kurds' ability to gear up the unrest, the regime promptly made political overtures to the Kurds. After half a century of regime indifference, the citizenship issue was suddenly resolved by a presidential decree in April 2011. Concerned primarily with diverting precious resources to the anti-regime demonstrations taking place in majority-Arab cities, the regime pursued the strategy of maintaining the loyalty of minority groups and depicting the uprising as an essentially Sunni Arab sectarian revolt. ${ }^{309}$

\footnotetext{
${ }^{308}$ Lund, 52.

${ }^{309}$ International Crisis Group. "Syria's Kurds: A Struggle within a Struggle", Middle East Report No. 136, Brussels, Belgium, January 22, 2013, 8.
} 
The Kurds had little sympathy for the regime and the memories of the Syrian Arabs' indifference towards the brutal regime crackdown on the Kurds in 2004 were still fresh. For the Kurds, being at the forefront of the protest movement not only carried the risk of harsh regime repression, but also might have allowed the regime to play up the ethnic divide and rally Arab support against "Kurdish secessionism" just as it had in 2004. Hence, the Kurdish parties kept any inclination to protest in check in order to spare the Kurdish areas violent confrontation, and to benefit from the regime's weakness to gain concessions regarding Kurdish rights. As a consequence, both the demonstrators and the government forces in Kurdish areas kept a low profile throughout 2011 to minimize the risk of clashes. This situation was interpreted by the radically anti-regime Sunni Arab opposition as an indication the Kurdish parties bet on a dialogue with the regime to the detriment of the revolution.

\section{Establishment of the Syrian Kurdish National Council}

Despite the fact that both the Kurds and the regime were intent on minimizing risks of confrontation in accordance with their own individual political concerns, this situation in no way meant that the Kurdish opinion of the regime, shaped by decades of repression, had shifted. According to the Kurdish parties, discrimination against the Kurds was not limited to either the regime or the opposition groups who would potentially come to power in case Al-Assad falls. In that sense, for the Kurdish parties and activists at large, the problem of the Kurds was not necessarily with the regime, but 
with the political and social structure that works to exclude them, disrupts their livelihood, and attempts to Arabize them. ${ }^{310}$

Hence, rejecting both the opposition and the regime and determined to keep the Kurdish areas free from fighting between the rebels and the government forces, the Kurdish parties took matters in their own hands by establishing their own opposition coalition in late 2011, the Syrian Kurdish National Council (KNC). The KNC was officially formed on October 26, 2011 in Erbil, Iraq, under the sponsorship of the Kurdistan Regional Government, following the creation of the SNC. The mission of the KNC was to find a peaceful solution to the Kurdish issue within the framework of a democratic and pluralistic Syria, while emphasizing that the Council is part of the revolution and refusing all negotiations with the regime. ${ }^{311}$

The KNC lists four main demands for the Kurds in the post-Assad era:

1. Political decentralization for the government that would be based on the recognition that Syria is a multi-cultural, multi-lingual, and multiethnic country.

\section{A secular state.}

3. Constitutional recognition of the Kurdish issue, a constitutional assurance that the Kurdish people are on their historic land, and the lifting of all discriminatory policies that have been deliberately applied to the Kurdish people such as the Arabization policies in Syria, the Arabized name changes of existing towns and villages and demographic changes.

\footnotetext{
${ }^{310}$ Khoury, Ernest, “Stuck in the Middle: The Struggle for Syria’s Kurds,” Alakhbar, 23 March, 2012.

${ }^{311}$ Hossino, Omar, Tanır, İlhan (March 2012). "The Decisive Minority: The Role of Syria's Kurds in the Anti-Assad Revolution," A Henry Jackson Society Report, 4-5.
} 
4. The recognition of the Kurds' right to self-determination in a form that would be decided in a national Kurdish referendum within the integrity and unity of the Syrian land. ${ }^{312}$

Dr. Abdulhakim Bashar, Chairman of the KNC, asserts that it is not only the Kurds, but also the Druze, Ismailis, Alawites and Christians in Syria who have been ignored by the SNC, which is responsible for the failure of Syria's minorities to participate as united communities in the revolution. He underscores the importance of political decentralization in Syria, particularly in the context of achieving an effective transition to democracy, which requires giving guarantees and assurances to the minorities befitting of their rights and benefits. ${ }^{313}$ He explains the role of the Kurds within this process as follows:

We (the Kurds) are more organized and recognized as a society within Syria and other Arab countries than other minorities. If we do participate (in the revolution) more actively, other minorities will feel more assured and follow suit. The regime has tried to convince the world that the conflict is between them and the Arab Sunnis. We want to prove that wrong. The revolution is not sectarian but it is being threatened by sectarian interests. ${ }^{314}$

In its inaugural session, the $\mathrm{KNC}$ voted against a demand to overthrow the regime and restricted itself to a more general call for democracy. It was declared that:

The crisis in Syria can only be resolved through a change in the authoritarian and totalitarian system and its organizational, political, and intellectual structures. The security state must be dissolved and a more secular, democratic, diverse, parliamentary, and decentralized state must be constructed. ${ }^{315}$

\footnotetext{
${ }^{312}$ Weiss, Michael, "Syrian Kurd Leader: Revolution Won't Succeed Without Minorities”, Interview with Dr. Abdulhakim Bashar, Chairman of the Kurdish National Council, The Atlantic, January 20, 2012.

${ }^{313}$ Ibid.

${ }^{314}$ Ibid.

${ }^{315}$ KurdWatch Report 8, 32.
} 
Alongside the protests organized by youth groups, the $\mathrm{KNC}$ staged demonstrations to promote its particular agenda. Rather than solidarity with the nationwide rebellion, street protests organized by the Kurdish parties specifically voiced demands for Kurdish self-determination and systemic change. A member of the KNC explains the Council's position in the following way:

It's not that we don't want the regime to fall. Let it fall 1,000 times. But if the political infrastructure stays the same, regardless of whether the regime stays or goes, we as Kurds won't have our rights. So we need to change the whole system, because the infrastructure hammers in the idea of a centralized state. ${ }^{316}$

The SNC made repeated attempts to incorporate the $\mathrm{KNC}$, as bringing in a major minority group was crucial for the SNC to claim that it represents a broad spectrum of the opposition. Nonetheless, the talks between the SNC and KNC collapsed in January 2012 when the SNC refused to provide in written guarantees of political decentralization and the right to self-determination for the Kurds within Syria's territorial unity. ${ }^{317}$ The attempts of the SNC to integrate the Kurdish parties continued in the "Friends of Syria" conference convened in Tunis in February 2013. Burhan Ghalioun, the head of the SNC, sought to reassure the Kurds by stating that the new Syria will have a decentralized government through the empowerment of local authorities. However, it was noted that the SNC is open to discuss only "administrative" decentralization and refuses any form of "political" decentralization that implies formal autonomy or federalism. Given the SNC's weak position on the Kurdish demands, all the Kurdish parties in the SNC, with the exception of the Future Party, suspended their membership and joined the KNC.

\footnotetext{
${ }^{316}$ Crisis Group Interview, Erbil, January 5, 2012 in International Crisis Group Report (2013). 11-12.

${ }^{317}$ Hossino, Tanir, 6.
} 
Tensions between the $\mathrm{KNC}$ and the $\mathrm{SNC}$ escalated further when the latter published a new document in April 2012,, titled "National Charter: The Kurdish Issue in Syria." The document confirmed the SNC's "commitment to constitutional recognition of the national identity of Kurdish people, and consider the Kurdish issue part and parcel of the national discourse, and recognize the national rights of the Kurdish people within the framework of the unity of Syria's land and people."318 The document also called for the "expansion and empowerment of local government" in order to mitigate Kurdish demands for decentralization. However, these overtures did little to advance SNC-KNC negotiations as the document excluded language recognizing the Kurdish nation within Syria living on their historical land. Furthermore, immediately following the publication of the document, Burhan Ghalioun stated in an interview there is no such thing as "Syrian Kurdistan" and that the Kurds should not be taken over with the illusion of federalism, equating it with a demand for secessionism. ${ }^{319}$ Ghalioun's statements caused renewed protests from the KNC and in Kurdish areas in Syria.

The Kurds became further alienated during the Arab League-hosted opposition meeting in Cairo in July 2012, when Arab participants refused to include the term "Kurdish nation" in the meeting's final declaration, which resulted in the withdrawal of Kurdish groups from the conference. It was stated by the Arab groups that the term "Kurdish nation" was rejected because of the "consequences" it might have. For Kurds,

\footnotetext{
318 Syrian National Council, National Charter: The Kurdish Issue in Syria, available at http://www.syriancouncil.org/en/issues/item/620-national-charter-the-kurdish-issue-in-syria.html (Accessed November 8, 2012).

319 “Burhan Ghalion: There is No Such Thing As Syrian Kurdistan,” Rudaw, April 17, 2012.
} 
on the other hand, the stance of the Arab opposition signified the possibility of a new era of persecution against them in the future. ${ }^{320}$

The Kurds' relationship with the Syrian opposition did not markedly improve after the decision of the SNC to unify with several other opposition groups, which resulted in the creation of the Syrian National Coalition in Doha, Qatar in November 2012. The members of the KNC participated in the preliminary talks. Nevertheless, immediately after the formation of the Coalition, its leader, Ahmed Moaz al-Khatib, stated that the Kurdish demands on a new constitution would be discussed only after the regime's ouster. As the new coalition insisted on postponing negotiations over the future status of Kurds after the regime's fall, the relations between the KNC and Syrian opposition once again came to an impasse. It was declared that the $\mathrm{KNC}$ refused to participate in the Syrian National Coalition unless written the opposition provided guarantees that Kurdish demands will be satisfied in the post-Assad state.

\section{The Role of the Democratic Union Party}

The PYD has considerable popular support in the Kurdish regions in Syria, which goes back to the support base the PKK built among the Syrian Kurds during the 1980s and 1990s. The establishment of the PYD in Syria in 2003 was the PKK's response to its weakened presence in Syria due to the improved Turkish-Syrian ties following the capture of Abdullah Öcalan. As the relationship between the PKK and the Syrian regime deteriorated after 1999, members of the PYD were exposed to widespread arrest and persecution during the regime's brutal repression of the Qamishli uprising in 2004. Nonetheless, this situation changed when Turkish-Syrian relations once again became

\footnotetext{
320 “Kurdish Parties Walk Out of Syrian Opposition Conference in Cairo,” Rudaw, July 5, 2012.
} 
strained because of Turkey's active support for the Syrian opposition after the eruption of the 2011 uprising. Bashar Al-Assad quickly revived the old policy of playing the "Kurdish card" by seeking to co-opt the PYD to strengthen his leverage vis-à-vis Turkey by using the threat of an empowered PKK. While this shifting landscape offered the PYD an opportunity to strengthen its presence in Syria, its reluctance to confront the regime prompted increasing charges of collusion.

The link between the PYD and the PKK has been a major matter of controversy for both the Syrian opposition and Turkey because of concerns over preventing the PKK from regaining power in northern Syria. The PYD leaders never denied PYD's affiliation with the PKK. Salih Muslim, the chairman of the PYD, has noted the PKK and the PYD share the same ideology and respect for Öcalan's leadership, but underscored that the organizational structure of the two parties is different and that the PYD is a distinct organization that acts according to the distinct characteristics of politics in Syria. ${ }^{321}$ Muslim acknowledged that the PKK and the PYD consult to each other in making decisions, yet the PKK respects that the PYD is in charge in Syrian Kurdistan and can do what is best for Syria's Kurds. ${ }^{322}$

Since the beginning of the uprising, PYD demonstrations were more pro-Kurd than anti-regime. In other words, rather than adopting the discourse of "regime change," the PYD focused on bolstering the position of the Kurds within the uprising as well as boosting its standing on the ground in Syrian Kurdistan. The fact the PYD abstained from

\footnotetext{
${ }^{321}$ BBC Turkish’s Interview with the PYD leader Salih Muslim Muhammad. May 27, 2012.

322 "PYD Leader Salih Muslim: Syrian Government Has Lost Control in Kurdish Areas," Rudaw, July 10, 2012.
} 
using anti-regime language, coupled with its reputation as the successor of the PKK's legacy in Syria, quickly put it in the spotlight on accusations of siding with the regime. Nonetheless, the accusations against the PYD relied largely on "suspicions" and "speculations" rather than any credible evidence. ${ }^{323}$ After the eruption of the uprising, the relationship between the PYD and the regime could be best explained in the context of their coinciding interests under the existing political circumstances in Syria. The regime sought to contain anti-regime protests by benefiting from Kurdish-Turkish and TurkishArab tensions while the PYD seized the opportunity to consolidate its position and advance the Kurdish cause in Syria. While the positions taken by the two towards each other developed mainly out of convenience, their relationship remained essentially contentious. The growing influence of the PYD in the Kurdish regions of Syria weakened the regime's hold in the country's northeast. The PYD, in the meantime, came into conflict with both the Arab and other Kurdish opposition groups due to persistent allegations of cooperating with the government.

In July 2012, significant developments took place in Syria that directly affected both the uprising and the Kurdish opposition. In mid-July, the PYD drove out government officials and security forces from several Kurdish cities, effectively taking control of these territories. On July 21, 2012, an ultimatum was issued by the PYD calling on all members of the Syrian army to withdraw from the Kurdish areas or face

\footnotetext{
${ }^{323}$ See Tanır, İlhan, Van Wilgenburg, Wladimir, Hossino, Omar (2012). "Unity or PYD Power Play? Syrian Kurdish Dynamics After the Erbil Agreement," Henry Jackson Society Report. The report was criticized on the grounds that it is biased and looks at the Kurds in Syria from the perspectives of dominant nationalist discourses in the region e.g. Turkish and Arab nationalism. See Keles, Janroj, "Kurds in Syria and the Old Concept of "Good Kurds" and "Bad Kurds," Kurdistan Commentary, November 15, 2012.
} 
consequences. ${ }^{324}$ By July 24, 2012, the PYD forces took control of all the Kurdish areas in Syria except for the city of Qamishli, following the withdrawal of the government security and political units from these areas. Anti-PYD actors, particularly Turkey, claimed that the capture of Kurdish towns by the PYD without resistance from the government forces is further proof of collaboration between the PYD and the regime. Nonetheless, the PYD pointed to the weakening of the regime and the Kurds' organizational power as reasons for the government's decision to avoid confronting the Kurds. In a BBC interview Salih Muslim underscored that observation:

As the clashes were spreading all over Syria, we took action to protect the Kurdish regions from violence. We are able to govern ourselves. We have the power for to do so. We warned them (government forces) to leave the Kurdish areas. Otherwise we would resort to different measures. They were aware of the people's demands and that's why they gave in without blood being spilled. ${ }^{325}$

It is true that despite sporadic clashes between the regime forces and the Kurds, the main Kurdish towns and cities in northern Syria were secured without much of a fight. The importance of July 2012 for the regime was that the Arab opposition launched an offensive in Damascus. For the first time, the uprising spread to the capital, which was alarming for the government. Bashar Al-Assad had loosened his grip on the Kurdish regions, which allowed him to tighten it elsewhere. Enhanced PYD control in the country's north was potentially beneficial for Assad in terms of constraining the Arab opposition and preventing them from taking control of the border areas, which provided

\footnotetext{
324 “Syria Update: Kurds give ultimatum to Syrian Security Forces," Rudaw, July 21, 2012.

325 "Crisis in Syria emboldens country's Kurds," BBC News Middle East, July 27, 2012, available at http://www.bbc.co.uk/news/world-middle-east-19021766 (Accessed October 19, 2012).
} 
the regime a further opportunity to exploit both the Turkish and Arab fears of Kurdish secessionist aspirations.

However, the regime was also aware of the Kurds' organizational capacity and its ability to mobilize on a large scale since the events of Qamishli in 2004. The PYD, in particular, draws its strength from its effective organization. After it was officially established in Syria, the PYD formed local committees that were in charge with specific activities in Kurdish regions. The local committees were formed mainly for the organization of Kurdish society as part of the PYD's “democratic self-governance project," which was accepted in the third party conference in 2007. After the beginning of the unrest, those committees took a more active stance by opening cultural and language centers throughout Kurd-populated areas. The fact that these activities met no government resistance played a significant role in raising suspicions about Baath-PYD collaboration. Nonetheless, Salih Muslim states that:

The regime has had no possibility to attack us. If it does attack us, it will see what happens. We are profiting from the unrest. It is a historical chance for us. We have a right and we are making use of it. ${ }^{326}$

Muslim also explains the purpose of these activities in the context of PYD's vision of the future of the Kurds and democracy in Syria:

These are concrete steps to democratic autonomy. By this we do not mean autonomy that needs to be clear. It's a matter of creating a new society from the bottom up. It's about culture, institutions, structure, organization, towns, and cities...the PYD advocates for a free, democratic and plural Syria in which all minorities are recognized and respected within the country's political framework. In this sense, what has been achieved so far

\footnotetext{
${ }^{326}$ KurdWatch. Interview with Salih Muslim Muhammad, Chairman of the PYD, November 8, 2011. http://kurdwatch.org/html/en/interview6.html (Accessed January 8, 2012).
} 
in Western Kurdistan could be seen as a model for the rest of the country. $^{327}$

The PYD also established a militia named People's Protection Units (YPG), which are responsible for maintaining order and protecting the lives of the people in Kurdish-inhabited areas. The YPG was established after the 2004 Qamishli clashes, but it did not become active until the 2011 uprising. Since the uprising, the YPG has functioned as a defensive security force in the Kurdish areas, deploying forces in cities, forming security check points, and controlling the boundaries of majority-Kurd populated areas as well as border areas alongside Iraqi Kurdistan and Turkey.

On the ground, Arab rebel groups have largely stayed away from Kurdishmajority areas. Similar to the strategy pursued with respect to the regime, the PYD leadership repeatedly warned the armed Arab opposition group, Free Syrian Army (FSA), to not intrude into Kurdish areas. The main concern of the PYD as well as the other Kurdish parties is to protect the Kurdish areas from Arab-Baath clashes as it is well known that once the FSA enters Kurdish towns, it will attract regime forces to intervene as well. The FSA, on the other hand, despite its priority to overthrow the regime, is unwilling to project weakness by allowing the Kurds to assert control in certain parts of Syria. With more important battles to wage elsewhere in the country, the FSA heeded to the warnings of the Kurds in practice, while at the same time adhering to its refusal to concede to Kurdish demands for political decentralization in principle. Although the FSA's continued efforts to form battalions in Kurdish areas caused tensions between the

${ }^{327}$ Ibid. See also Salih Muslim Muhammad, "Western Kurdistan Could Be a Model for a Free and Democratic Syria," Press Release, May 7, 2013, London. 
FSA rebels and YPG militias, the parties signed a truce on 5 November 2012, agreeing on cooperation in fight against the Assad regime. ${ }^{328}$

The actions of the PYD created discontent on all fronts. Turkey claimed that the PYD took control of the Kurdish areas in coordination with the regime, while the KNC and Arab opposition accused the PYD of betraying the revolution by collaborating with the government. Nevertheless, regardless of how each party interpreted the events, the movement of the PYD drew substantial world attention to the Syrian Kurds. As of November 2012, the PYD emerged as the dominant force on the ground in Syrian Kurdistan and established itself as a powerful third force in Syria that is willing to confront Turkey, the Arab opposition, and the Assad regime.

\section{Intra-Kurdish Party Relations}

Since the beginning of the uprising, the PYD has been exposed to much criticism by the other Kurdish parties because it primarily strives to consolidate its own position and monopolize the Syrian Kurds instead of working to advance the Kurdish cause. The party was also exposed to numerous allegations of threatening and kidnapping Kurdish activists from both the SNC and $\mathrm{KNC}$, which were all rejected by Salih Muslim. Moreover, membership of the PYD in the NCB further exacerbated the claims that the party is co-opted by the Assad regime.

On July 11, 2012, the PYD and KNC decided to take a united stand against Assad and signed an agreement to jointly administer the Kurdish areas in Syria that were liberated from the Assad regime with the newly-created Supreme Kurdish Committee

\footnotetext{
${ }^{328}$ Van Wilgenburg, Wladimir, "Syrian Rebels and Kurdish Group Sign Truce," Rudaw, November 5, 2012.
} 
(SKC). Until this accord (the Erbil Agreement), the Syrian Kurdish scene was largely defined by an uneasy rivalry between the $\mathrm{KNC}$ and the PYD. When the $\mathrm{KNC}$ was established in October 2011, the primary reason behind the PYD's refusal to join was the KNC's ties with the alliance between Turkey, the US and Kurdistan Regional Government. The fact the KNC was formed under the sponsorship of KRG distanced the PYD particularly because of the party's concern over a possible Turkish influence on Kurdish politics in Syria. Salih Muslim claimed that the PYD would not work with anyone who supports foreign intervention and that the PYD would join the $\mathrm{KNC}$ on the condition that the Council openly denounces its support for Turkish intervention in Syria.

The Erbil Agreement was the result of the two Kurdish camps' recognition of their own vulnerabilities. The discontent among the Kurdish opposition groups regarding the rise of the PYD had been mixed with an awareness concerning its efficiency. "Whether we want it or not, the PYD is currently the strongest force in al-Qamishli," said Azad Muhiyuddin, a member of a Kurdish youth group. "Without the PYD nothing works. What the PYD has accomplished in fifteen days, the KNC could not achieve in five months. ${ }^{329}$ Although the KNC was critical of the cultural and military activities of the PYD, the local committees and security forces organized by the PYD in the Kurdish areas played a significant role in filling the vacuum caused by the state's weakening power and it effectively responded to the Kurdish populations' thirst for strong and efficient leadership. Lacking both the grassroots support and a military force, it became increasingly hard for other Kurdish groups to avoid cooperation with the PYD.

\footnotetext{
${ }^{329}$ KurdWatch Interview with Azad Muhiyuddin, "The Kurdish Patriotic Conference is nothing more than a name. Compared to the PYD it has accomplished Nothing" KurdWatch, March 21, 2012. Available at http://www.kurdwatch.org/syria_article.php?aid $=2484 \& z=$ en\&cure $=240$ (Accessed June 21, 2012).
} 
As for the PYD, cooperation with the KNC was a necessary step in order for the party to strengthen both its domestic and international legitimacy. While the KNC enjoys international partners, the PYD has been largely isolated internationally despite being strong locally. There has also been a widespread expectation among Syrian Kurds, including the supporters of the PYD, that the Kurdish parties work together to secure Syrian Kurdish rights. Despite the strong domestic support it enjoys, it has been increasingly difficult for the PYD leadership to ignore this expectation. In that sense, the reconciliation reached through the Erbil Agreement was significant for the PYD in terms of both maintaining local legitimacy and countering the accusations of loyalty to the PKK and the regime by reassuring the Kurdish public that Syrian Kurdish interests are the party's priority.

The creation of the Supreme Kurdish Committee was an important step in terms of overcoming mutual suspicions. Nevertheless, tensions persisted mainly because of the fact that the PYD remained dominant in administering the Kurdish towns and commanding the Kurdish militia. As a single party, the PYD's organizational capacity largely derives from its ability to make decisions and execute tasks quickly, whereas the fact that the $\mathrm{KNC}$ has to accommodate the interests of fifteen different parties greatly hampers its ability to organize effectively. Despite the conciliatory rhetoric of the Erbil Agreement, distrust persisted on both sides. Both the PYD and the KNC accused each other of pursuing separate agendas instead of committing to the authority of the SKC. For the $\mathrm{KNC}$, the relationship of the PYD with the PKK and the regime continued to be a controversial issue. The PYD, for its part, expressed concern over fragmentation within $\mathrm{KNC}$ and its dysfunctional decision-making procedures. 
The implementation of the Erbil Agreement remained fragile. However, despite attempts by both parties to suspend their membership during the months following the accord, by late 2012, both the PYD and the KNC came to the conclusion that none of them could afford antagonizing the other and that preventing Kurdish infighting should be the priority of all the Kurdish parties in Syria. Although they hold different visions for the Kurds' role in a post-Assad Syria, ${ }^{330}$ the PYD and KNC reflect common concern over the Arab opposition's reluctance to recognize Kurdish rights, judging from the dominance of Muslim Brotherhood in the SNC and its vision of the new order that will eventually emerge in Damascus.

The Erbil Agreement created an opportunity for both camps to focus on the common desire to resist both the regime and Arab domination. The unfolding of the Syrian Kurdish political scene as a battleground between the pro-PKK and pro-Barzani forces only played into the hands of the regime and the Arab opposition which seek to benefit from Kurdish infighting. Furthermore, the lack of unity among the Kurdish political forces on the ground severely diminished the international backing that Syrian Kurds strongly need in order to increase their leverage vis-à-vis the Arab opposition and achieve Kurdish demands in the post-Assad Syria. Despite their ideological and political affiliations with their external sponsors, both the PYD and the members of the KNC must forge a political role that is attuned to local realities. Continued efforts to implement the Erbil accord despite continuing tensions are primarily the result of the understanding that

\footnotetext{
${ }^{330}$ The purpose of the KNC was mainly to achieve a federal Syria similar to the status that the Kurds achieved in Iraq. Whereas, the PYD mainly promoted the "democratic autonomy" project formulated by Abdullah Ocalan, which is based on a bottom-up organization of Syria's different regions according to their distinctive national, religious, economic and cultural characteristics.
} 
a strategy of reconciliation in the name of Syrian Kurdish unity has the best chance of succeeding.

\section{The Role of the Regional Actors in the Syrian Uprising}

The Syrian uprising has significant potential to challenge the status-quo in the Middle East as the consequences of a possible regime change in Syria are likely to affect the foreign policies of a number of critical players in the region. As far as the Kurdish question in Syria is concerned, this is shown in the relationships of the PYD and the KNC with three important actors: Turkey, the PKK and the Kurdistan Regional Government.

Throughout the first half of 2012, the KRG President Massoud Barzani made a concerted effort to reconcile the two Kurdish blocs in Syria. His attempts finally succeeded in July 2012 with the conclusion of the Erbil Agreement between the PYD and the KNC. The Erbil Agreement highlighted a number of concerns held by Barzani. By hosting the founding meetings of the $\mathrm{KNC}$, Barzani aimed at enhancing his potential role in Syrian Kurdish politics by uniting the fragmented Kurdish parties in the country. Nonetheless, Barzani's involvement with the Syrian Kurds was largely shaped by both the long-term tensions between the PKK and Barzani's KDP, and the KRG's close relationship with Turkey, whose primary aim was to contain the influence of the PYD in Syria.

Given their different ideological roots, Abdullah Öcalan's PKK and Barzani’s KDP have always presented two competing paradigms of Kurdish nationalism. The PKK's Marxist-Leninist background was set against the KDP's conservative-tribal character. The PKK abandoned most of its Marxist-Leninist thinking by the early 1990s, but remained essentially opposed to tribalism. Furthermore, the relationship of each party 
with Turkey has been in stark contrast since 2007, when the KRG started to develop strong economic ties with Turkey in order to reduce the Iraqi Kurds' dependence on Baghdad as opposed to the PKK's continued struggle against the Turkish government for the political and cultural rights of the Kurds in Turkey.

Barzani's strategy of supporting the KNC after the eruption of the uprising served the purposes of both expanding the KPD's sphere of influence among the Syrian Kurds vis-à-vis the PKK, and mitigating the concerns of Ankara, which saw Barzani as an ally in containing and marginalizing the PYD. However, given the political and military strength of the PYD, it soon became apparent that this strategy was not sustainable in the long run, particularly in the context of the pan-Kurdish ambitions of Barzani. There is no doubt Barzani has considerable influence over the Kurdish populations in Turkey, Iran, Iraq and Syria given the international legitimacy enjoyed by KRG as well as the respect for long-term political and military struggle conducted by the KDP throughout the twentieth century under the leadership of his father, Mullah Mustafa Barzani. Nevertheless, since its launch in the 1980s, the PKK movement has posed a serious challenge to the KDP by achieving extensive grassroots support not only among the Kurds of Turkey, but also in other parts of Kurdistan. In this respect, the Erbil Agreement underscored both Barzani's acknowledgement of the strength of the PKK and the recognition of the political and military risks associated with PYD-KNC fighting.

Given the memories of a bloody civil war between the KDP and PUK in the 1990s, Kurd-to-Kurd warfare is highly unpopular among the Kurds across the Middle East. Both the KDP and PKK are aware that they cannot ignore the expectations of the masses for Kurdish unity. Besides, it is well known that any Kurdish infighting in Syria 
will have implications for the already delicate PKK-KDP relations in northern Iraq. Thus, Barzani's efforts to establish a PYD-KNC pact reflects a careful balancing act between avoiding a PKK-KRG conflict in Iraq, refraining from antagonizing the KRG's regional ally, Turkey, and a quest for enhancing his regional image among the Kurds.

Turkey's policy towards the Kurdish issue in Syria is shaped entirely in the context of the long-term battle between the PKK and the Turkish government. It was alarming for Turkey when the PYD took control of several Kurdish towns in northern Syria in July 2012. Perceiving these developments as a manifestation of the PKK's growing power in Syrian Kurdistan, Turkish Prime Minister Recep Tayyip Erdoğan immediately declared that Turkey had the "undisputed right" to intervene if the PKK were to set up camps in Syria. ${ }^{331}$

Looking back on what happened in Iraq after the US intervention in 2003, Turkey's major concern is the possibility that Syrian Kurds might enjoy the same autonomy in the post-Assad Syria as did the Kurds in post-Saddam Iraq. However, a possible unilateral Turkish intervention not only lacks international backing but also carries the risk of causing conflict between Turkey and PYD's armed militia with direct consequences for Turkey's own Kurdish problem. The revival of the peace talks between Turkey and the PKK in the first half of 2013 put further pressure on Turkey to soften its policy towards the Syrian Kurds. Thus, Turkey increasingly turned to its ally, the Kurdistan Regional Government, in order to maintain influence over the course of events shaping the Syrian Kurdish politics throughout the uprising.

\footnotetext{
331 "Don't Provoke Us, Erdogan Says in Stern Warning to Syrian Kurds," Today's Zaman, July 26, 2012.
} 
Although Turkey gave Barzani a leading role in containing the PYD, the interests of the two actors are likely to diverge in the long term. Since the development of closer economic and diplomatic ties between Turkey and KRG after 2007, Turkey constantly put pressure on Barzani to fight against the PKK in Qandil Mountain. However, these pressures never led to a Turkish-KRG military cooperation against the PKK. Barzani declared the KRG is principally opposed to a military solution of the Kurdish problem in Turkey and that the peshmerga forces would not take part in any military operation against the PKK within Iraqi territory. Barzani's refusal to confront the PKK derives from both his unwillingness to get involved in a Kurd-on-Kurd military confrontation, and the popularity of the PKK among the Kurdish youth in Iraqi Kurdistan.

Since 2011, Turkey used the same strategy of putting pressure on Barzani to limit the influence of the PYD in Syria by playing on the competition between the KDP and PKK and Barzani's pan-Kurdish ambitions. From the perspective of Turkey, the Erbil Agreement represents a strategy of containing the PYD by increasing the voice of the pro-Barzani KNC in the decision-making procedures concerning the Kurds in Syria. For Barzani, the Erbil Agreement serves more to "integrate" the PYD, as opposed to "containing" it, with the expectation the PYD would be encouraged to cut ties with the PKK in order to become a political body focused exclusively on the Syrian Kurdish interests. This strategy gives Barzani additional leverage over Ankara by strengthening the KRG's soft power by putting it in the position to be a possible mediator between Turkey and the PYD, similar to the role Barzani is willing to play in the peace talks between Turkey and the PKK. 
The peace process that took effect between the PKK and Turkey in early 2013 is undeniably tied to the developments in Syria with important effects on Iraq. The possibility of the emergence of a decentralized Syria similar to the federal structure in Iraq after the collapse of the Assad regime coupled with the rise of the PYD among the Syrian Kurds, prompted Turkey to launch a solution process. The PKK, on the other hand, uses the power of the PYD in Syria as leverage against Turkey during the peace negotiations. As a response to the Turkish fears of the emergence of another autonomous Kurdish region across its borders, the PYD leader Salih Muslim repeated several times that he is ready to engage in dialogue with Turkey and that the PYD has no intention of threatening Turkish security. ${ }^{332}$

The relations between Turkey and PYD largely echo the pre-2007 situation between Turkey and KRG. Nonetheless, a more sanguine approach towards the alliance between the KNC and PYD and the emerging Kurdish region in Syria might, in fact, provide Turkey with significant opportunities to consolidate its regional power. Turkish support for the Syrian Kurds will not only make significant contributions to the ongoing peace process in Turkey, but also expand Turkey's role in the evolution of the Kurdish question in the Middle East. Lacking significant international support and largely alienated from the Tehran, Damascus and Baghdad regimes, the Kurds of the Middle East are increasingly looking to Turkey as their only potential ally in the region. Salih Muslim's statements since the Erbil Agreement confirm this stance, but on the condition that Turkey solves its own Kurdish problem in a democratic way and recognizes the rights of the Kurds in the region.

${ }^{332}$ Çandar, Cengiz, “Turkey’s Kurdish Initiative May Affect Syria’s Kurds,” Al Monitor, 14 April, 2013. 


\section{CHAPTER VI}

\section{KURDS IN IRAN}

It was a sensitive time and the world media was watching Iran. Kurdish participation in the protests would have shown that the Iranian movement was not only the Green Movement, and that the Kurdish movement was part of it. Because Kurds make up only twelve percent of the population in Iran, they cannot change Iran alone. ${ }^{333}$

The post-presidential election protests in Iran in 2009 had grown into a major popular opposition movement that posed a great challenge to Iran's power structure. It was a unique phenomenon that had not occurred since the Iranian revolution that took place nearly 30 years ago. The Kurdish areas in Iran as well as the other areas populated predominantly by Iran's ethnic and religious minorities remained mostly calm and did not join the so-called Green movement. Commenting on the Green movement's approach to the ethnic movements in Iran, Abdullah Muhtadi, the leader of one of the major Iranian Kurdish organizations, the Komala, emphasized, "the Green movement's platform was not very clear and did not include anything that would please the Kurds." 334

Muhtadi's statement is significant in the context of the multi-ethnic and multicultural structure of Iranian society, which goes back to pre-Islamic times, but this diversity has become a significant component of Iranian political life particularly during the post-constitutionalism era. Rather than homogeneous, the Iranian citizenry is a differentiated community with important crisscross divisions in terms of socioeconomic class backgrounds, genders, cultural practices, provincial and ethnic ties, and political

\footnotetext{
333 "Dissident Leader Says Plight of the Iranian Kurds Little Known in the West," Rudaw, June 15, 2012. ${ }^{334}$ Ibid.
} 
aspirations. ${ }^{335}$ In this respect, while the Iranian Kurdish movement has common ground with Kurdish movements in other parts of Kurdistan, its development in the Iranian context has been considerably intertwined with the broader problem of national minorities in Iran.

Although Iran had several characteristics favorable for the development of nationalism in the pre-modern period, such as the concept of a territorial Iran, the Persian language and Shia Islam, the phenomenon of nationalism has become a major key to understanding Iranian attitudes and political behavior in the twentieth century. There have been many different conceptions of Iranian nationalism in the modern era, including linguistic, territorial, ethnic and religious. Firouzeh Kashani-Sabet points out that "what is unique to the nationalist discourse in Iran is the way in which the varying emphasis on these complementary but often competing articulations of nationalism has transformed Iranian politics in radical ways. ${ }^{, 336}$ In this regard, different constructions of nationalism have generated a contentious sociocultural sphere at various stages of Iran's modern history.

Among the various articulations of Iranian nationalism, the policies of centralism and the emphasis on territorial integrity remain to be the most persistent themes when addressing the national question in Iran particularly after the inception of the first Pahlavi state in 1926. This situation created a relatively stable type of relationship between the

\footnotetext{
${ }^{335}$ Farhi, Farideh (Summer 2005). "What Does the Ninth Presidential Election Say About Iranian Politics?" in Middle East Program Occasional Paper Series, Iran After the June 2005 Presidential Election, Woodrow Wilson International Center for Scholars, 8-9.

${ }^{336}$ Kashani-Sabet, Firouzeh (2002). "The Evolving Polemic of Iranian Nationalism" in Iran and the Surrounding World: Interactions in Cultural Politics edited by Nikki R. Keddie, Rudolph P. Matthee Seattle: University of Washington Press, 162.
} 
state and minority groups in Iran that was manifested in the successive regimes' perception of Iran's national diversity as more of a "problem" than as a matter of pluralism and democratic participation. While the definition of "Iranianness" was affected by dramatic alterations in the understanding of nationalism in Iran throughout its modern history - ranging from the secular nationalism of the Pahlavi State to the religious focus of the Islamic Republic - minority-state relationships have been principally marked by "continuity" rather than "change."

Abbas Vali observes that Kurdish nationalism in Iran has its roots in the political and cultural processes and practices of the construction of the modern nation state and national identity in Iran. ${ }^{337}$ If the revolution of 1905-6 marks the birth of Iranian nationalism, Kurdish responses to the politics of territorial centralism and the cultural process of the construction of a uniform Iranian national identity pursued by the Pahlavi state mark the formation of a Kurdish nationalist movement in Iran, which culminated in the Republic of Mahabad in $1946 .^{338}$ The Mahabad Republic not only marked the advent of modern nationalism in Kurdistan, but it also defined the Kurdish issue in Iran as a denial of the Kurdish identity by the sovereign power and the Kurds' resistance to this denial.

The establishment of the Republic of Mahabad, along with the Azerbaijani movement in northern Iran during 1945-46, played a significant role in transforming the discursive articulation of the "national question," which was mainly defined in terms of a single Iranian national identity that eclipsed ethnic loyalties. In effect, the nationalist

\footnotetext{
${ }^{337}$ Vali (1998). 82.

${ }^{338}$ Vali (2011). 1-2.
} 
movements of the Kurds and Azeris transformed the national question in Iran into an "ethnic question" and challenged the democratic promise of the constitutional movement of 1906 on grounds it failed to recognize the ethnic and cultural diversity of the Iranian society.

In the essentially settled territorial self-understanding of Iran, the ethnic challenge the Kurdish and Azerbaijani movements posed was portrayed as a threat to the territorial integrity and unity of the Iranian nation. Additionally, the fact the ethnic challenges to the sovereign power emerged as Soviet-backed movements expanded the anti-imperialist scope of the Iranian national discourse and consolidated the territorial conception of Iranian nationalism, which was defined in terms of ethnic separatism and external intervention. The popular appeal of this anti-imperialist narrative has historically been facilitated by the association of domestic problems with external threats, which became an integral part of Iran's intricate political culture. The oil nationalization of 1951, the Iran-Iraq war of 1980s, and the recent discussions on Iran's nuclear program enabled successive governments to unite and rally the Iranian people around a common discourse of national strength, defense, and national pride. In this context, the reality of Iran's ethnonational diversity has often been represented as a national security issue in official state discourses rather than a political question of how to respond to the demands of ethnic minorities for equal rights.

\section{The Status of Ethnic and Religious Minorities in Iran}

The question of minorities has often remained obscure in Iranian nationalist historiography. The nationalist ideas promoted by the Constitutional Revolution of 1906 were oriented towards establishing a modern nation state, protecting Iran's autonomy vis- 
à-vis foreign powers and consolidating democracy through greater citizen participation in political life. Although the Constitutional Law of 1906 sets forth the institutional form and organizational structure of the state, the conditions of citizenship were explained vaguely and the concepts of citizen and citizenship were not explicitly addressed. Rather, Iranians are considered "subjects" of the monarch. The rights and obligations commonly associated with citizenship in the modern democratic sense of the term appear in this notion of "subject" in the Constitution.

The constitutionalist discourse introduced the millat (the people) as a unified force and the source of sovereignty, invested with the right to determine the policies of the government through its representatives to the Majlis (Parliament). ${ }^{339}$ In the constitutionalist discourse, millat signified everyone regardless of professional, social, or religious status. ${ }^{340}$ In defining the constituent elements of the millat, the constitutionalists emphasized language as the essential component of national identity, which resulted in attempts to purify the Persian language of Arabic terms and to dissociate Iran from Islam. In their struggle for a new identity, the emphasis on pre-Islamic history and the Persian language emerged as important components of a strategy for breaking away from ArabIslamic culture and identity and forming a new political conceptualization. ${ }^{341}$

The Constitutional Law of 1906-07 does not contain an ethnic definition of the conditions of citizenship and remains silent on the subject of minorities. The ethnic and

\footnotetext{
${ }^{339}$ According to article 26 of the Supplementary Constitutional Law of 1907, "The powers of the state derive from the nation." Quoted in Tavakoli-Targhi, Mohamad (1990). "Refashioning Iran: Language and Culture during the Constitutional Revolution," Iranian Studies, 23 (1/4): 98.

${ }^{340}$ Article 8 of the Supplementary Constitutional Law of 1907 states: "The inhabitants of the Empire of Iran shall enjoy equal rights before the law."

${ }^{341}$ Tavakoli-Targhi, 93.
} 
cultural diversity of the Iranian society were subsumed under the general notion of the Iranian people, whose identity was defined by pre-Islamic history and the Persian language. Using this framework, Millat was defined as a people speaking in one language and provided the primary discursive condition for the articulation of the Constitutionalist language and identity. Although the Constitution contains a separate section on the institutional framework for local administrations, the ethnic and linguistic particularities of certain provinces simply were not taken into consideration. The local and regional languages, including Kurdish, were neither recognized nor denied.

The marginalization of ethnic differences in the Constitutional era revealed the latent authoritarianism of the discourse of modernization, which required unity, permanence and the incorporation of citizens into Iran's nascent democratic polity on the basis of the rights and obligations defined in the Constitution. The incorporation of citizens on the basis of a collective identity was precluded by the silence of the Constitution on the ethnic and cultural diversity of Iran. Soon, however, the emerging Iranian nationalism broke this silence through the official public discourse, particularly after the rise of the Pahlavi State, with an argument for national revival and progress that was premised on the need for political and economic modernization requiring political and administrative centralism. ${ }^{342}$

Reza Shah Pahlavi (1926-1941) extended state control over all aspects of life the economy, transportation, education, language, culture, media, foreign trade, and

\footnotetext{
${ }^{342}$ Vali (2011). 5.
} 
religion ${ }^{343}$ History and language were the primary constituent elements of the emerging Iranian nationalism under the Pahlavis. In his attempt to diminish the influence of Islam in Iran, Reza Shah sought to shape Iranian nationalism by infusing it with a distinctly secular ideology. The state ideology advertised "Iranians" as a "pure Aryan race" in order to de-emphasize Arab and any Islamic influences on Iranian history. Hence, pre-Islamic culture and Persian language were officially promoted while writing or speaking in nonPersian languages in public places was declared illegal and punished. ${ }^{344}$ During Reza Shah's reign, all school textbooks were printed in Persian by the authorities in Tehran, and the teaching of any other languages was strictly prohibited. ${ }^{345}$

The policies of territorial centralism and the construction of a uniform Iranian national identity were pursued by force by the first Pahlavi state from 1926 to 1941, and then, after a short lull, enforced again by the second Pahlavi state until 1979. ${ }^{346}$ The Iranian Revolution of 1979 and the downfall of the monarchy did nothing to effectively change the national dynamic. Despite the dramatic and significant shift from the secular nationalism of the Pahlavi State to the religious focus of the Islamic Republic, relatively little change was seen in minority-state relations following the Islamic revolution. ${ }^{347}$ The

\footnotetext{
${ }^{343}$ Hassanpour, Amir (1994). "The Nationalist Movements in Azerbaijan and Kurdistan, 1941-46" in $A$ Century of Revolution: Social Movements in Iran edited by John Foran, Minneapolis: University of Minnesota Press, 86.

${ }^{344}$ Ibid.

${ }^{345}$ Atabaki, Touraj (2000). Azerbaijan: Ethnicity and the Struggle for Power in Iran, London: I. B. Tauris Publishers, 58.

346 Farhi, Farideh (March 2005). "Crafting a National Identity Amidst Contentious Politics in Contemporary Iran," Iranian Studies, 38 (1): 12.

${ }^{347}$ Higgins, Patricia J. (1984). "Minority-State Relations in Contemporary Iran,” Iranian Studies, 17 (1): 39.
} 
Islamic Revolution emphasized religious identity as supranational and supra-ethnic, and like the linguistically-defined conception of national identity promoted by the Pahlavis, the Republic refused to recognize heterogeneity in Iran.

After years of difficulties under the monarchy, minorities expected the Islamic Revolution would enhance their position and afford them greater autonomy and cultural rights. Some believed Ayatollah Khomeini's calls for the revival of the Islamic community would promote the recognition of the ethno-religious pluralistic nature of society and pave the way for the acknowledgement of the loyal, but autonomous ethnic areas. However, hopes for decentralization and greater rights for minorities were dashed early on as the new government continued to enforce the extant system and proved to be largely negligent of the ethnic issue in Iran. The Islamic Republic created a centrally controlled system similar to the Shah but, did it within an Islamic framework.

The most striking and obvious contrast between the Pahlavi and Islamic Republican State is the use of Islam as an element of common culture. Although the Pahlavis identified themselves as Muslims, religion was not used as a basis for identification with the state. Rather, the monarchy sought to develop and extend the sense of Iranian nation defined primarily in terms of Persian language and literature and preIslamic history. Islam is taken as the focal symbol of identity between the state and the people in the Islamic Republic, and is central to the common culture promoted by the state. ${ }^{348}$ However, the revolution imbedded Shia Islam as the main pillar of the Iranians'

\footnotetext{
${ }^{348}$ Beck, Lois (May 1980). "Revolutionary Iran and Its Tribal Peoples," MERIP Reports, no. 87; Cottam, Richard W. (1979), Nationalism in Iran: Updated through 1978, Pittsburgh: University of Pittsburgh Press; Helfgott, Leonard M. (1980). "The Structural Foundations of the National Minority Problem in Revolutionary Iran," Iranian Studies, 13 (1-4): 195-204; Frye, Richard N. (1968). Persia, London: George Allen and Unwin Ltd.
} 
collective identity, which prompted grievances by the Sunnis who were mostly Turkmen, a minority of Arabs, Balochs and Kurds. According to the Shia leadership, to talk about ethnic minorities in the Islamic domain was considered an offence against true religion.

In November 1979, Ayatollah Khomeini explained why the mention of ethnic minorities had been eliminated from the common culture:

Sometimes the word minority is used to refer to people such as the Kurds, Lurs, Turks, Persians, Balochs, and such. These people should not be called minorities, because this term assumes that there is a difference between these brothers. In Islam, such a difference has no place at all. There is no difference between Muslims who speak different languages, for instance, the Arabs or the Persians. It is very probable that such problems have been created by those who do not wish the Muslim countries to be united. They create the issues of nationalism, of panArabism, pan-Turkism, and such isms, which are contrary to Islamic doctrines. Their plan is to destroy Islam and the Islamic philosophy. ${ }^{349}$

Ethnic differences lie at the intersections of religious differences in Iran. Most of the Sunnis constitute distinct ethnic minorities residing in the Kurdistan, Sistan and Balochistan, Golestan and Khuzestan provinces. ${ }^{350}$ Under the Constitution of Islamic Republic, only certain religious minorities, such as Zaroastrians, Christians and Jews, are recognized. ${ }^{351}$ The constitution does not recognize ethnic minorities and the government does not use ethnicity or language as a variable in conducting the national census. Thus, it is difficult to find accurate numbers on the different ethnic groups in Iran. Estimates suggest that fifty-one percent of Iran's population is ethnic Persian with the rest being Azeris (twenty-four percent), Gilaki and Mazandarani (eight percent), Kurd (seven

\footnotetext{
${ }^{349}$ Radio Tehran, December 17, 1979, in BBC/SWB December 19, 1979, quoted in McDowall (1996). 271.

350 Tohidi, Nayereh (2009). "Ethnicity and Religious Minority Politics in Iran" in Contemporary Iran: Economy, Society, Politics edited by Ali Gheissari, Oxford: Oxford University Press, 299.

${ }^{351}$ Iranian Constitution, Article 13.
} 
percent), Arab (three percent), Lur (two percent), Baloch (two percent), Turkmen (two percent), and other (one percent). ${ }^{352}$

The Constitution of the Islamic Republic establishes the principle of equality in Article 19, which states that "all people of Iran, whatever the ethnic group or tribe to which they belong, enjoy equal rights; and color, race, language, and the like, do not bestow any privilege.” The constitution also has specific provisions guaranteeing equal rights to minorities. Article 15 of the constitution states that:

The official language and script of Iran, the lingua franca of its people, is Persian. Official documents, correspondence, and texts, as well as textbooks, must be in this language and script. However, the use of regional and tribal languages in the press and mass media, as well as for teaching of their literature in schools, is allowed in addition to Persian.

Persian, despite being the official language, is the mother tongue of barely half of the population in Iran. Other languages include Turkic, Kurdish, Balochi, Luri, Arabic, Gilaki, Assyrian, and Armenian. ${ }^{353}$ As a state entity, Iran is constitutionally at ease with its ethnic minorities and the Islamic Republican state has not passed sweeping laws to restrict minority language publications or cultural activities. Nor does the Islamic Republic proclaim itself for Persians in an exclusive way. Its constitution recognizes the national minorities' right to use their languages in the mass media and education so long as they are used in conjunction with Persian.

Although the constitution allows the teaching of local and ethnic languages in schools, no permanent measures have been introduced in Iran's education system to

\footnotetext{
${ }^{352}$ Hassan, Hussein D. (May, 2007). Iran: Ethnic and Religious Minorities, CRS Report for Congress, Public Broadcasting Service, Boston, MA.; CIA. World Fact Book, October 4, 2012.

${ }^{353}$ Tohidi, 299-300.
} 
facilitate teaching in minority languages or to teach such languages as a second language. ${ }^{354}$ Even if Article 15 is fully implemented, it falls short of guaranteeing the full scope of human rights associated with the use of one's mother tongue. While it permits the use of local languages in media and education, the phrase "regional and tribal languages" includes no recognition of the linguistic identities of national and ethnic minorities or of the mother language as a fundamental principle. Further, the article does not obligate - only "allows" - the state or private sector to provide instruction of literature or presentation of mass media in ethnic languages. ${ }^{355}$

The use of the Kurdish language in print and education in Iran is frequently thwarted. The ability to teach Kurdish in schools has long been an issue of contention between the Kurds and the central government. There are no Kurdish public schools in Iran. There are Kurdish courses in both public and private universities in Tehran, but not in the areas inhabited by the Kurds. ${ }^{356}$ The state-run radio and television broadcasts are predominantly in Persian and only a limited number of programs are run in minority languages. ${ }^{357}$ There are media in the Kurdish language, but this is subject to censorship as is any other media in the country. There is no Kurdish television channel but some programs broadcast in Kurdish on the general channels. ${ }^{358}$ Self-censorship is best strategy

\footnotetext{
${ }^{354}$ Amnesty International. “Iran: Human Rights Abuses against the Kurdish Minority,” July 30, 2008, 11.

${ }^{355}$ Tohidi, 303.

${ }^{356}$ See point 94 in The Cultural Situation of the Kurds. European Union Parliamentary Assembly, July 7, 2006. Available at http://assembly.coe.int/main.asp?Link=/documents/workingdocs/doc06/edoc11006.htm (Accessed October 11, 2011).

${ }^{357}$ Hakki, Majid (December 2008). "The Political System and Kurdish Question in Iran”, Kurdish Issue in Iran: Journal of Ghasemlou Center for Research and Political Development, Issue 1, 29.

${ }^{358}$ See point 93 in The Cultural Situation of the Kurds.
} 
to survive for many media-outlets. The regime establishes boundaries on discourse and topics such as regional ethnic demands are off limits. ${ }^{359}$ Journalist accounts and news media publishing in Kurdish or coverage of Kurdish-related issues have been targeted by the regime, especially since President Mahmoud Ahmedinejad took office in 2005.

The Islamic Republic clearly broke with the Pahlavi practice of disallowing the use of regional languages in broadcasting and publications. Problems arise when Kurdish rights activists link their human rights work - drawing attention to the government's failure to observe international human rights standards - to their Kurdish identity. ${ }^{360}$ In other words, while limited space exists to assert Kurdish cultural identity, there is no space to operate as Kurds politically. Kurds seeking to express their views or beliefs in connection with their opposition politics face the same restrictions as all Iranians. Thus, it can be said that it is the destruction of the political organization of the Kurds rather than their ethnic identity per se, that forms the strategic objective of successive regimes in Iran, particularly in the context of the persistent emphasis placed on politics of territorial centralism.

When analyzing the role of minority politics in the Islamic Republic, it is important to note the central problem lies more with the implementation than with the law itself. Though the correct implementation of the constitution could contribute to the solution of Iran's ethnic issues, the aforementioned provisions were never fully implemented and had little potency in reality. The essence of the legal problems facing

\footnotetext{
${ }^{359}$ Hakki, Majid (December 2008). "Kurdish language in the Iranian Legal Framework", Kurdish Issue in Iran: Journal of Ghasemlou Center for Research and Political Development, Issue 1, 44.

${ }^{360}$ Amnesty International (2008). 1.
} 
Iran's national minorities is not that there is a body of discriminatory, anti-minority or Persian-first legislation. Rather, the ethnic movements in Iran face the same obstacles confronted by other pluralistic, secular political movements in the country - that much law in the Islamic Republic permits arbitrary clerical rule and fails to protect basic freedoms. ${ }^{361}$ Constitutional provisions establishing the right to freedom of expression, political participation and other basic freedoms are rendered impotent by clauses asserting the primacy of undefined Islamic interests. ${ }^{362}$

\section{The Legacy of the Republic of Mahabad}

The discourse on the rights of ethnic and religious minorities officially became part of Iran's political agenda during the post-revolutionary period and importance of the ethnicity in the discussion on democratization in Iran increased in the 1990s. The issue of minority rights became part of the political agenda during the reform movement of the 1990s, which was evidenced in the slogan of Mohammad Khatami's presidential election campaign in 1997, "Iran for all Iranians." To better understand of both the pro-democracy movement in Iran and the role of ethnicity in the evolution of the democratization discourse, one needs to focus on the process that resulted in the establishment of the Kurdish Republic of Mahabad in 1946.

The Mahabad Republic is generally addressed in academic discourse from two perspectives: as a symbol of Kurdish nationalism and statehood in the twentieth century and as an attempt at Kurdish independence that was victimized by the power politics of

\footnotetext{
${ }^{361}$ Hicks, Elahé Sharifpour, Hicks, Neil (2007). "The Human Rights of Kurds in the Islamic Republic of Iran" in Kurdish Identity: Human Rights and Political Status edited by Charles G. MacDonald, Carole A. O'Leary, Florida: University Press of Florida, 212.

${ }^{362}$ Ibid.
} 
the Cold War era and Soviet expansionism in the Persian Gulf. Western scholarship explains the Kurdish movement of 1945-46 in terms of Soviet communist intentions rather than from the perspective of the Kurds' legitimate rights to self-determination or self-rule. ${ }^{363}$ Unified by the ideological and political perspectives of anticommunism, these accounts protected the monarchical system that was a stronghold of the West against the USSR and avoided highlighting the struggle of the peoples of Iran for democracy, rights, and freedom. ${ }^{364}$ Besides providing historical and descriptive accounts of the rise and fall of the Republic, the literature generally falls short of portraying the Mahabad Republic as a genuine national struggle of the Kurds, particularly in terms of its repercussions for the transformation of the "national" question in Iran into a question of rights, civil and democratic liberties.

Abbas Vali's (2011) detailed discussion of Kurdish nationalism from 1905 to 1947 provides an in-depth analysis of the Kurdish nationalist discourse promoted by the Republic of Mahabad. However, Vali considers the relationship between the Kurdish movement and Iranian government largely within the framework of an ethnically and linguistically defined dichotomy between the Kurdish "self" and Persian "other," which he sees as the main defining characteristic of Kurdish identity. ${ }^{365}$ In this respect, Vali

\footnotetext{
${ }^{363}$ See Ramazani, Roullah (1975). "The Autonomous Republic of Azerbaijan and the Kurdish People's Republic: Their Rise and Fall," in The Anatomy of Communist Takeovers edited by Thomas Hammond, New Haven: Yale University Press; Sicker, Martin (1988). The Bear and the Lion: Soviet Imperialism and Iran, New York: Praeger.

${ }^{364}$ Hassanpour, 81.

${ }^{365}$ According to Vali, the ethnic and linguistic unity of the Kurdish community in Iran is constituted by its otherness and hence its differences with the sovereign identity in modern Iran. In this sense, the sovereign identity is constitutive of the Kurdish community and the processes and practices which reproduce Kurdish otherness also at the same time define its unity and cohesion (Vali 2011, xiii-xiv).
} 
emphasizes the importance of the Kurdish Republic in terms of the Kurdish resistance to strategies of domination and control, which were expressed in terms of the struggle for the defense of ethnic and linguistic rights. Accordingly, he does not consider the demands for cultural rights and autonomy as part of the Kurdish political endeavor to challenge and transform the foundations of Iran's body politic. Rather, he views the political requirements of the autonomist discourse emphasized in the founding manifesto of the Republic as incompatible with the ethnic-nationalist political project as defined in terms of political sovereignty of the Kurdish nation.

Shortly before the declaration of the Republic, when asked whether it was true that the Kurds wanted separation and independence from Iran, Qazi Muhamad, the leader of the Democratic Party of Iranian Kurdistan (KDPI), responded, "No, it is not true, this is because we want the Iranian government to implement the constitutional law, we want to live autonomously under the Iranian flag." ${ }^{366} \mathrm{He}$ explained the position of the KDPI by stating, "The Kurdish nation in Iran should be free to administer its own affairs and live within the Iranian borders." ${ }^{367}$ The political objectives expressed in Muhammad's statements were also listed in the KDPI's party program, declared on November 8, 1945. According to the program, some of the party policies were:

1. The Kurds to be free and independent in the management of their local affairs and to receive Kurdish independence within the borders of Persia.

2. Be allowed to study Kurdish and to administer their affairs in the Kurdish language.

\footnotetext{
${ }^{366}$ Ghazi Muhammed's remarks in conversation with the editors of the press in Tehran shortly before the declaration of the Republic. Kurdistan, No. 1, January 11, 1946.

${ }^{367}$ Ibid.
} 
3. Government officials definitely to be appointed from among the local population.

4. Members of the Kurdistan Provincial Council to be elected immediately in accordance with the Constitutional laws, to supervise all public and Government works. ${ }^{368}$

The autonomist discourse in the KDPI Program and the founding manifesto of the Republic of Mahabad is informed by a specific reading of the Iranian Constitution of 1906, which provides the legal basis for advocating pluralism, the decentralization of political power, administrative and cultural autonomy, and respect for ethnic and religious differences. The Iranian Kurdish movement tied the realization of the ethnic and linguistic rights of the Kurds directly to the establishment of a genuine and lasting democratic political process in Iran through the "correct" implementation of the constitution. The Kurdish leadership referred to the institutional framework outlined by the constitutional provisions that regulate the Provincial and District Councils (anjumans) in providing their demands for self-government with legal legitimacy. The articles concerning the Provincial Councils in the Constitution of 1906 included:

Art. 90. Throughout the whole empire provincial and departmental councils shall be established in the accordance with special regulations. The fundamental laws regulating such assemblies are as follows.

Art. 91. The members of the provincial and departmental councils shall be elected immediately by the people, according to the regulations governing provincial and departmental councils.

Art. 92. The provincial and departmental councils are free to exercise complete supervision over all reforms connected with the public advantage, always provided that they observe the limitations prescribed by Law.

\footnotetext{
${ }^{368}$ Great Britain, Public Record Office, Foreign Office (FO), Series FO, FO/371/45436, 8 November 1945. Quoted in Koohi-Kamali, Farideh (2007). 242-243.
} 
The Kurdish leadership considered to the Provincial and District Councils to be democratic measures and devices for the decentralization of power in Iran, which could provide an appropriate venue for the recognition of the multi-ethnic and multi-cultural structure of Iranian society. Thus, it became tantamount to revive the Provincial and District Councils in order to implement decentralized administration, which had been suppressed by the Pahlavi regime, and fulfill the Kurdish quest for cultural and administrative autonomy.

Speaking as the leader of the KDPI at a press conference in Mahabad two weeks before the declaration of the Republic, Qazi Muhammad made it clear the Kurdish demands were based on the "implementation of the Constitutional Law by the Iranian Government and that the Provincial and District Council for Kurdistan, as stipulated in the Constitutional Law, should be established at once to administer and supervise all social and governmental affairs." ${ }^{, 369}$ The Kurdish leadership's articulation of the demand for regional autonomy not only underscores a legitimate, popular democratic right central to democratic governance in Iran as a whole, but also the ethno-cultural aspect of the movement that demanded the recognition of Kurdish identity and cultural and administrative autonomy.

According to Vali, the popular-democratic presentation of the politics of regional autonomy marginalized Kurdish ethnicity and ethnic/national differences. ${ }^{370} \mathrm{He}$ asserts that "early statements of the Kurdish position played down ethnic differences with Persians; they are subordinated to the necessity of a common Iranian cause, the struggle

\footnotetext{
${ }^{369}$ Kurdistan, No. 1, January 11, 1946 and No. 2, January 13, 1946.

${ }^{370}$ Vali (2011), 92.
} 
for democracy in Iran." ${ }^{371}$ Vali's analysis of the discursive dynamics of Kurdish demands is driven essentially by his definition of Kurdish identity, which he characterizes primarily by the Kurdish community's ethnic-linguistic difference and its "otherness" relative to the sovereign identity in Iran. Accordingly, for Vali, the Kurdish search for autonomy and cultural rights in the struggle for democracy in Iran marginalizes the Kurdish ethnicity and its ethnic and linguistic otherness in the Kurdish nationalist discourse.

Consider, on the other hand, the democratic discourse promoted both in Qazi Muhammad's statements and in KDPI's party program, which principally targets the dictatorial apparatus in Tehran which is viewed as the primary obstacle to the recognition of the distinctiveness of the Kurds vis-à-vis the Persians and other ethnicities. For them, it is the ethnic and linguistic distinctiveness of the Kurds that underlies the conception of Kurdish independence, which is principally associated with the establishment of a democratic institutional framework to provide the Kurds with authority over the management of their local affairs. Qazi Muhammad, addressing a public meeting in Mahabad shortly after the declaration of the Republic, argues:

The dictatorial apparatus in Tehran ... for reasons that I have explained has not yet understood the affairs of the Kurds properly. Otherwise [it would have understood that] even after achieving our full independence, we would wish to make it clear to the central government and also show to the world that the Kurds have not done these things in order to deny their brotherhood with the Persians, or to be proved not to be Iranians, but rather to oppose the dictatorial apparatus [in Tehran] ... . Otherwise if freedom could be established in Iran there is no reason why all those who live in Iran could not hold hands in brotherhood. ${ }^{372}$

\footnotetext{
${ }^{371}$ Ibid.

${ }^{372}$ Kurdistan, No. 50, May 27, 1946.
} 
There is no doubt ethnic and linguistic differences played a role in the formation of the Kurdish identity not only in Iran, but also in other parts of Kurdistan. However, as confirmed by Qazi's statements, if "otherness" is to be considered as a constitutive element in the formation of Kurdish identity, then it is not the "Persian" ethnicity per se, but the dictatorial apparatus of the Iranian central government that defines "otherness" for the Kurds. The presentation of the Kurdish cause as such does not serve to marginalize the Kurdish ethnicity as claimed by Vali. On the contrary, it promotes a discourse of "coexistence" between the Kurds and the Persians as two distinct ethnicities under a single democratic framework.

Kurdish demands for the implementation of the 1906 Constitution focused on the need to implement the Provincial and District Councils, but the discourse of the Republic involved more than political and administrative decentralization. Implicit in the demands for the use of the Kurdish language in cultural, educational and administrative realms and the appointment of government officials in the Kurdistan Province from among the local population was a demand for a reformulation of the constitutional concept of citizenship. The demand for local administrative autonomy not only involved political decentralization, but also sought recognition of the multi-ethnic nature of Iranian society.

The autonomous governments established by the Kurdish and Azerbaijani movements in 1945-46 implemented various reforms in the fields of education, economy, agriculture, women's and minority rights, which were seen by opposition forces throughout Iran as a model of progress under a democratic regime. ${ }^{373}$ The emergence of Kurdish and Azerbaijani autonomous regimes transformed the crucial problem

\footnotetext{
${ }^{373}$ Hassanpour, 93-94.
} 
confronting the various collectivities co-existing under the same political rubric in Iran. The national question was no longer defined merely as a question of national identity and national rights, but also as a constant reminder of the deficiencies and shortcomings of the citizenship, democracy, and democratic political process within the juridico-political framework of Iranian sovereignty. In other words, the focus of the national question in Iran became less of an identity issue - "Who is an Iranian?" - and more of an institutional matter - "How can the Iranians of all colors and ethnicities build a common political life and effective institutions of government?"374

\section{The Kurds and the State After the Islamic Revolution}

After the collapse of the Mahabad Republic, the Kurdish movement in Iran suffered serious setbacks. The KDPI continued its presence mostly as a clandestine organization. Throughout the 1950s and 1960s, the Kurdish political activists sought safe haven in Iraqi Kurdistan, which made it practically impossible to effect change in Iran.

Since the autonomous governments in Mahabad and Tabriz were crushed by the central government of Tehran in 1945-1946, successive governments saw any ethnicrelated demands as a security issue and threat to Iran's territorial integrity. These autonomous movements remained largely in the background until they reappeared in the antimonarchy push that precipitated the 1979 Revolution. As the Iranian regime was facing serious unrest in the late 1970s, the political conditions provided the KDPI an opportunity to come back and raised hopes it could once again be a legal political party. The end of the monarchy was viewed by the Kurds as a unique opportunity to push for autonomy and recognition of their cultural rights by the new government in Iran.

\footnotetext{
${ }^{374}$ Farhi, 13.
} 
Therefore, the Kurds enthusiastically supported the Iranian Revolution of 1979, and broadly participated in the revolutionary process from the outset. However, Kurdistan and Tehran quickly became antagonistic as it became apparent the goals of the Kurds were not compatible with Ayatollah Khomeini's objective of establishing a strong and centralized Islamic state.

Although the purpose of ridding Iran of the Pahlavi Dynasty's rule mobilized the entire Iranian population and brought together diverse political interests, from clerics to communists as well as democrats and human rights activists in 1979, the democratic and republican interests were soon subsumed by the more conservative, theocratic rule of Ayatollah Khomeini. A renewed opposition to the Islamic government in Iran began to form shortly after the revolution. Having toppled the Shah, the former revolutionaries were soon being challenged by groups thirsting for change.

In post-revolutionary Iran, religion became a major divisive factor. The 1979 revolution created an Islamic state with a Shia leadership and marked a shift from a linguistic nationalism to a religious one. The new Iranian nationalism gained great strength from having the majority of the people from a single sect, but for those outside the Shia orbit, identification with this nationalism became difficult. ${ }^{375}$ Sunni Muslims made up about ten percent of the population in Iran and majority of Kurd, Baloch and Turkmen populations are of this sect. As non-Persian speakers in Sunni Muslim communities, the Kurds found their relationship vis-à-vis the Islamic Republic similar to their relationship with the Pahlavi state.

${ }^{375}$ Cottam, 67. 
After the fall of the Shah's regime, Kurdistan was among the first areas to rise up against the new Islamic Republic. The reasons were easily discernible. When the Kurds put their demands before the Islamic Republic, they were told all Iranians are Muslim and ethnic identification is not to be emphasized. As individuals of non-Persian Muslim background, one might expect the Kurds to have been integrated into the Islamic Republican state more easily than into the Pahlavi state. However, according to Article 12 of the Constitution of the Islamic Republic, the official religion of Iran is Islam and the Twelver Ja'fari School, which emphasizes the Shia nature of the state and establishes Shia Islam as the principle of unity. The article states, "this principle will remain eternally immutable." If the Kurds could not be distinguished as an ethnic minority, then a majority of them might have been able to invoke minority status as Sunnis. However, Article 13 of the Constitution recognizes only the Zoroastrian, Jewish and Christian Iranians as religious minorities. Consequently, the Islamic Republic's Shia exceptionalism as well as its binding ideology of pan-Islamism, which dismisses ethnic identification, the Kurds remain marginalized with respect to the state either as Kurds or as Sunnis.

The first official Kurdish challenge to the new government occurred on April 1, 1979, when a national referendum was held in Iran concerning the name and form of the new government. The Kurds, at the decision of the major Kurdish parties, KDPI and Komala, and many other secular groups in the country boycotted the referendum. When the referendum resulted in an overwhelming victory for the new Islamic regime, the Kurds shifted the focus of their political struggle to the drafting of Iran's new constitution. They took part in the election of Assembly of Experts on August 18, 1979, 
a group responsible for writing the new constitution. However, the Kurds were denied seats at the Assembly of Experts gathering in 1979, when Dr. Abdul Rahman Ghassemlou, the elected representative of the Kurdistan region, was prevented from participating in the Assembly's first meeting. ${ }^{376}$

Although the draft constitution contained democratic provisions to safeguard the rights of all Iranians, the Kurds as well as many other nationalist and secularist groups felt the constitution did not address their demands adequately. For example, Sheikh Ezzeddin Hussein, the spiritual leader of the Sunni Kurds in Mahabad, argued since Iran was a multinational state, its constitution must legally recognize the cultural, economic, and sociopolitical rights of all ethnic and religious groups in the country. ${ }^{377}$ Having no identity as Kurds or as Sunnis, according the constitution, the Kurds saw no point in voting for the new constitution after the proclamation of the Islamic Republic. They abstained almost unanimously.

Because of their numbers, the Kurds' actions had little effect in hampering the project of the Islamic government, but they were strong enough to present a localized threat to the fledgling regime. The new leadership ignored the Kurdish demands and opted to crush unrest through military means. Regular clashes between the Kurds and government forces continued until the late 1980s with occasional interruption for peace negotiations. In 1988, following the Iran-Iraq war, several negotiations took place

\footnotetext{
${ }^{376}$ Ahmadzadeh, Hashem, Stansfield, Gareth (Winter 2010). "The Political, Cultural and Military Reawakening of the Kurdish Nationalist Movement in Iran," The Middle East Journal, 64 (1): 18.

377 Entessar, Nader (2007). "The Kurdish National Movement in Iran Since the Islamic Revolution of 1979" in The Evolution of Kurdish Nationalism edited by Mohammed M. A. Ahmed, Michael Gunter, Costa Mesa, CA: Mazda Publishers, 263.
} 
between the Iranian government and the Kurdish side, led by the KDPI and Dr. Abdul Rahman Ghassemlou. Ghassemlou was ultimately assassinated by the armed diplomats of the Iranian government in Vienna on July 13, 1989, and three years later his successor, Dr. Sadiq Sharafkandi was also assassinated in Berlin on September 17, 1992. ${ }^{378}$ The deaths of the two leading Kurdish figures dealt a heavy blow to the Kurdish nationalist movement in Iran and evidenced the determination of the Islamic government to silence any opposition to its authority and.

\section{Towards the First Wave of Reform}

The wave of reform that emerged in Iran in the 1990s was a result of pressure coming from social forces such as students, women, and secularist and nationalist groups, who were seeking to change Iran's authoritarian political system and foster a democratized polity that respects fundamental human rights and freedoms. The reform movement played a significant role in crystallizing the power struggle among the contending forces within the Iranian regime: those who favored the democratization of the state, expansion of civil society and the creation of a legal order versus the conservative opposition. The reformist faction's popular quest for democracy, human rights and civil society posed a crucial challenge to the status of the Velayat-e Faqih and questioned its legitimacy. ${ }^{379}$

\footnotetext{
${ }^{378}$ Ibid. 21.

379 Ayatollah Khomeini expounded the concept of Velayat-e Faqih as a doctrine of governance that purports the government should be run in accordance with the Islamic sharia under the political "guardianship" (velayat) of a leading Islamic jurist (faqih) over the people. According to this doctrine, Ayatollah Khomeini was the first faqih or Supreme Leader of Iran after the Islamic Revolution of 1979.
} 
The source of power struggle between the reformist and conservative factions within the regime was rooted in the two conflicting and competing conceptions of sovereignty enshrined in the Iranian Constitution. One is the "popular sovereignty," which is derived from the indivisible will of the Iranian nation. The other one is the "divine" conception of sovereignty as derived from God's will. According to Article 5 of the constitution, the divine concept of sovereignty is by definition indisputable, unquestionable and absolute. It defines the predominance of the living "faqih" as the supreme source of authority and legitimacy whose absolute will defines the boundaries of political power and the juridical-political framework for the conduct of the state. ${ }^{380}$

The reform movement underscored the antagonism between the popular and divine conceptions of sovereignty in Iranian politics and tried to marginalize the divine conception of sovereignty in order to give the popular-democratic conception its due place in the constitution. ${ }^{381}$ The contentious relationship between the conservatives and reformists also gave rise to a conflict regarding the question of national identity in Iran. The religio-national identity promoted by the conservatives maintained a continuity from the Pahlavi state's focus on territorial centralism as the foundation of a nation-state and a uniform Iranian national identity, but based on the Shia culture. The reformists, on the other hand, emphasized liberal nationalist ideas identified with popular nationalism, which is distanced from strict Islamic morality and emphasizes instead the development of civil society, basic freedoms and human rights.

\footnotetext{
380 Vali, Abbas. Washington Kurdish Institute Conflict Resolution Forum, July 28, 1998, http://www.kurd.org/kcrf/ValiKCRF.html (Accessed December 23, 2011).

${ }^{381}$ Ibid.
} 
Many reformist intellectuals moved beyond the old paradigms of secular Aryancentered and religious Shia-centered homogenized Iranian identity. ${ }^{382}$ As the next revolution came of age, the reformist ideas showed an awareness that the experience with the Islamic Republic had made Islam, from a political standpoint, part of the problem and not the solution. ${ }^{383}$ The Iranian youth who comprise a large portion of the country's population became the main force behind the reform movement. The restrictive social conditions under which they lived increasingly alienated the youth from the conservative clerical establishment and led young people to distance themselves from religion and turned them, instead, into proponents of democracy and human rights. Nonetheless, despite the rights-based language of the pro-democracy forces in Iran, the status of religious and ethnic minorities continued to be a neglected in the movement's human rights discourse. The reformist goal to democratize the Iranian political culture did not question the state-sponsored notion of national identity that was based on the Shia Islamist exclusionary discourse of the conservatives.

Activists concerned with ethnic minority rights argue their ethnic-related demands are inseparable from national demands for greater democracy and socioeconomic development for all people of Iran. ${ }^{384}$ However, tension and distrust exist between many of the Iranian pro-democracy and human rights activists, and the ethno-nationalists who emphasize ethnic and minority rights. ${ }^{385}$ The tension derives from the fact that many

\footnotetext{
382 Tohidi, 319.

${ }^{383}$ Gheissari, Ali, Nasr, Vali (2006). Democracy in Iran: History and the Quest for Liberty, Oxford: Oxford University Press, 9.

${ }^{384}$ Tohidi, 310.

${ }^{385}$ Ibid. 308.
} 
politically active minority groups bear the stigma of separatism. On many occasions, human rights activists, intellectuals, and political organizations in the opposition were criticized by the minority groups on grounds they have been hesitant to speak out in support of ethnic and religious minorities of Iran or to condemn government repression of minorities. ${ }^{386}$ According to the proponents of ethnic minority rights, the democratic discourse of the Iranian opposition does not aim genuine political change in Iran, but serves to preserve the status-quo. In this respect, they accuse the opposition forces of making common cause with the regime's efforts to concentrate power in the central state and deny the political and cultural rights of minorities in Iran.

In challenging the state-sponsored notion of national identity, the ethnic movements emerged as "the third force" within the reform movement in Iran. While minority demands were congruent with the reformists' goals for greater democracy, economic progress and an end to clerical control over law and behavior, they also advocated for pluralism and multiculturalism, and criticized the reformist intellectuals for their failure to recognize Iran's multiethnic reality. In their attempt to shift the question of Iranian identity from its "national" perspective to its component peoples, minority groups speak not of an Iranian nation, but of Iranian peoples who are made up of different nationalities with distinct ethnic and cultural characteristics. Implicit in this notion is the

\footnotetext{
${ }^{386}$ Yusef Azizi Bani-Torof, for example, the former prisoner of conscience and an Iranian Arab writer and advocate of minority rights, complains about how human rights organizations in Iran such as the Center for Defenders of Human Rights in Iran (CDHRI) (Kanun-e Modafe'an-e Hoquq-e Bashar dar Iran), founded by Shirin Ebadi, and the Writers Association (Kanun-e Nevisandegan) fail to speak out in support of people in Khuzestan and in condemning government repression of Iranian Arabs. Quoted in Shemirani, Khosrow. "Vaqaye'-e Khuzestan az manzar-e hoquq-e bashari-hava siasat-madaran" (Events in Khuzestan from the viewpoint of human rights activists and politicians) Shahrvand, May 6, 2005.
} 
promotion of Iranian nationalism as a political force that is pluralistic and inclusive rather than homogeneous and exclusive.

The atmosphere of distrust is particularly strong between the Kurdish political parties and Iranian opposition groups because of the old suspicions of secessionism and autonomy-phobia among the Persian population. Similar to the successive regimes in Iran, the Iranian opposition groups including liberals, republicans, moderate Islamists and leftists, often showed indifference to Kurdish demands by rebutting the idea Iran is a multinational country. Given the continual socio-economic disparity between central Iran and its provincial peripheries, which are predominantly populated by ethnic minority groups, the interests of the minorities are linked with those of the Persian underclasses. Accordingly, the Marxist and socialist groups in Iran often had a closer association with the Kurdish cause than other opposition groups. However, even the Marxist-inclined Tudeh Party, which the KDPI relied on after the collapse of the Mahabad Republic, avoided the term "nationalities" in referring to the minorities in Iran in its program. ${ }^{387}$ Other opposition groups such as the National Front and Iranian National Republicans accused the KDPI leadership of separatism and argued that the idea that Iran is a multinational country was incompatible with the structure of the Iranian society and would cause the possible partition of Iran. ${ }^{388}$

\footnotetext{
387 Ghassemlou, A. R. (1993). "Kurdistan in Iran" in A People Without A Country: The Kurds and Kurdistan edited by Gerard Chaliand, New York: Olive Branch Press, 116-117.

388 Quoted in Tahiri, Hussein (December 2008). "Kurdish Nationalism in Iran: A Reassessment," Kurdish Issue in Iran: Journal of Ghasemlou Center for Research and Political Development, Issue 1, 13; Reaction to the Events of Kurdistan in Persian Publications, Compiled and published by the KDPI, No.7, June 1993, 31; Kurdistan, Organ of the Central Committee of Democratic Party of Iranian Kurdistan, No.189, September 1992, 4.
} 
Concerns over territorial integrity and the external threat of exploitation of ethnic tensions in Iran date back to the Kurdish and Azerbaijani movements of 1946-47. Kurds are only one-third the size of the Azeri community, which is the largest ethnic minority group in Iran. However, after the proclamation of the Islamic Republic, while the relationship between the Kurds and the Iranian state became strained, the Azeri community ceased to constitute a threat in the eyes of the new regime. Although Azeri aspirations for cultural rights continued, the Azeri people as a Shia community were better integrated into the religio-national identity promoted by the Islamic Republic. In this regard, despite the persistence of cultural, regional and linguistic differences, Azeri integration to the social and political system in Iran was smoother than other minorities, and they enjoyed representation at all levels of the political, military, intellectual and religious hierarchy. ${ }^{389}$

After the Islamic revolutionary regime established power, Iran's Turkmen, Baloch, Arabs, and Kurds staged revolts. The demands, despite their diversity, had much in common. Autonomous peoples in Kurdistan, Turkman Sahra, Balochistan or Khuzestan should exercise power in their own social, cultural, linguistic and economic affairs while the federal government managed foreign policy and economic, financial and defense issues at the national level. ${ }^{390}$ With the exception of the Kurdish challenge, the

\footnotetext{
${ }^{389}$ Wimbush, S. Enders (1979). "Divided Azerbaijan: Nation Building, Assimilation, and Mobilization between Three States" in Soviet Asian Ethnic Frontiers edited by William O McCagg, Brian D. Silver, New York: Pergamon Press, 61-81.

${ }^{390}$ Mojab, Shahrzad, Hassanpour, Amir (1996). "The Politics of Nationality and Ethnic Diversity" in Iran After the Revolution: Crisis of an Islamic State edited by Saeed Rahnema, Sohrab Behdad, New York: I. B. Tauris \& Co Ltd, 234.
} 
regime put each down relatively quickly. ${ }^{391}$ While the Islamic Republic was able to suppress the autonomous movements in Turkman Sahra, Khuzistan and Balochistan, it lost control to the Kurds in much of Kurdistan, especially in Mahabad. ${ }^{392}$ Although the regime eventually won the battle militarily in 1985, it lost the ideological and political war against Kurdish nationalism and there has been little support for the Islamic state, its ideology and politics in Iranian Kurdistan.

The Iranian state feels less threatened by Kurdish aspirations than Turkey, Iraq or Syria. However, from the perspective of the central government, the Kurds are more threatening than other ethnic groups in Iran not only because they are more geographically concentrated and a border minority, but because they are not demanding minor changes to the state framework, but a major reorganization. ${ }^{393}$ The major Kurdish opposition groups in Iran, KDPI and Komala, not only underscore the necessity of democratizing the political process in Iran, but also stress the need to accommodate the demands of the Kurds and other national minorities in a decentralized structure. The Kurdish call for democratization includes demands for rights and freedoms, and an examination of the rules and institutions Iranian society requires in order to achieve a more inclusive democracy. This articulation of Kurdish demands generates a new discursive terrain whereby the "ethnic" question becomes one of important arenas in which democratic and civil liberties in Iran and the struggle to build effective institutions converge with one.

\footnotetext{
${ }^{391}$ See Hiro, Dilip (1987). Iran Under the Ayatollahs, New York: Routledge, 111-113; Higgins, 56-59.

${ }^{392}$ Mojab, Hassanpour, 235.

${ }^{393}$ Higgins, 58.
} 
The Kurdish political forces in Iran have managed to continue their activities and maintain their organizational capacity to revive and challenge the regime time and again since 1946, despite the repression they have suffered. Although they lack the power to independently influence the course of events within Iran, the Kurds remained active in voicing the political, cultural and economic demands of minorities and played a crucial role in instigating public discussion of the ethnic minority issues in Iran. In sum, the Kurds became pivotal players with respect to the emergent role of the minorities as a "third force" in oppositional politics and in the movement for change in Iran.

The Kurdish movement's ability to sustain its capacity for struggle has led to recognition by the Islamic regime that should Kurds be joined by similarly situated minorities and/or by Shia Persian forces intent on the establishment of a secular state and a confederacy, the regime's support could be severely undermined. ${ }^{394}$ Given the fact the minorities make up a significant portion of the population, the Kurds had the potential to become key actors in achieving political change in Iran. Although the situation of the Kurds remained stagnant in the aftermath of the Iran-Iraq war, as the reform movement unfolded during the mid-1990s, the Kurds' potential to wield power was a factor difficult to dismiss by either the regime or the opposition.

\section{The Reform Movement and the Kurdish Challenge}

Muhammad Khatami's presidential election victory on May 23, 1997, was unexpected for the conservatives who had monopolized politics since the Islamic Revolution. The subsequent defeat of the conservatives in the February 2000

\footnotetext{
${ }^{394}$ Higgins, 58-59.
} 
parliamentary elections further increased expectations of political change. Khatami's election not only heightened hopes he would take Iran in new directions both at home and abroad, but also showed the genuine public demand for democratization in Iran.

Whether President Mohammad Khatami and his administration were truly advocates for reform and whether they lived up to the Iranian society's expectations of change are complicated questions to answer. Khatami's campaign promises did not materialize during his two terms in office and even though his policies opened up cultural and political space to a degree not previously witnessed in the Islamic Republic, he was harshly criticized by some opposition groups who claimed he was part and parcel of the clerical establishment that had ruled Iran with ferocity in the past two decades. They believed his presidency failed to bring major changes to any of the fundamental policies of the theocratic regime, particularly in terms of executions and the assassination of dissidents as well as women's rights. ${ }^{395}$ For these groups, Khatami's victory was nothing more than an extension of the internal factional fighting of the Shia political elite and genuine change in Iran could only come through the organization of a general uprising to overthrow the regime completely.

Regarding the question of minorities in Iran, Khatami's campaign put considerable emphasis on the inclusion of all Iranians in the political decision-making process with a specific focus on greater social and political freedoms for religious and ethnic minorities. Feeling deeply unhappy about the hardline Islamic regime, the Kurds and a majority of other ethnic groups, supported Khatami and his reform movement.

\footnotetext{
${ }^{395}$ Mohaddessin, Mohammad (1998). "The Myth of Moderation" in Foreign Affairs Committee of the National Council of Resistance of Iran, Iran Under Khatami: The Myth of Moderation, Auvers-sur-Oise, France, 2.
} 
After taking office in 1997, Khatami appointed Abdullah Ramazanzadeh to be the first Kurdish Governor General of Iranian Kurdistan. Ramazanzadeh, himself a Shia, appointed many Sunni Kurds to key roles in the government. ${ }^{396}$ In the sixth parliament (2000-2004), the Kurdish members of the Iranian Parliament organized themselves into a single faction representing the Kurdish provinces of Kurdistan and Kermanshah. ${ }^{397}$

Despite the relative cultural and political freedom enjoyed by the Kurds during Khatami's administration, political tensions and cultural grievances remained high in Iranian Kurdistan. The situation deteriorated following Khatami's failure to do anything about the violent suppression of the Kurdish demonstrators in February 1999, when Iranian Kurds staged mass protests against Turkey's arrest of the PKK leader Abdullah Öcalan. The President was exposed to harsh criticisms by the Kurdish parliamentarians who complained the central government did not apply same attention to the legal matters of the Kurds as it did in the capital. ${ }^{398}$ In 2001, the Kurdish representatives resigned en masse from the parliament, accusing Khatami's government of discrimination against the Kurds. ${ }^{399}$ Khatami's credibility further decreased when over half of the Kurdish MPs were prevented from participating in the February 2004 parliamentary elections. The

\footnotetext{
${ }^{396}$ Yildiz, Kerim, Taysi, Tanyel B. (2007). The Kurds in Iran: The Past, Present and Future, London: Pluto Press, 44.

${ }^{397}$ Ahmadzadeh, Stansfield, 21.

${ }^{398}$ The Kurdish parliamentarians were referring to the student protests of July 1999 in Tehran which were condemned by Khatami on July 13, 1999.

${ }^{399}$ Yildiz, Taysi, 44.
} 
election was boycotted by over seventy percent of the Kurds, and civil unrest occurred in Kurdish cities to protest the unfair elections. ${ }^{400}$

While Khatami enjoyed unprecedented public support, he had to work under certain institutional and operational constraints intrinsic to the complex nature of the Iranian political system, which is based on an uneven distribution of power divided between institutional political power and religious power. By the end of Khatami's eight years in office, the Iranian public was greatly disappointed with him and the reformist process. Similarly, the Iranian Kurds expressed dissatisfaction with the government, believing that Khatami's reformist platform fell far short of the promised improvement in integration and participation and had failed to engage the Kurds in a political process with the regime. ${ }^{401}$

Despite the overall dissatisfaction of the Iranian society with the Khatami government, the movement for change in Iran gained enormous momentum during the reformist process. The reformist ideal of advancing human rights, democracy and freedom in Iran had important effects on Iranian society. It is important to note, however, that reformist ideas derived from within the society itself, which had gradually became vigorous in initiation and agency after the revolution and eight-year war against Iraq. Therefore, although Khatami significantly influenced the grassroots movements in Iran, the changes promoted during his presidency were shaped by the social transformations that took place over a few decades that led to growing social pressure for democratic change.

\footnotetext{
${ }^{400}$ Ibid.

${ }^{401}$ Ibid.
} 
During the election that culminated in Khatami's victory, the ethnic factor emerged as one of the important aspects of the movement for change in Iran. This was particularly important in the context of the Islamist authorities' portrayal of Iran as a cohesive Shia state and its policy of denying recognition of ethnicities. As the rise of ethno-nationalism clearly influenced the reform movement, the power struggle between the reformist and conservative factions within the regime entered into a new phase. Challenging both the conservatives' portrayal of the ethnic problem in Iran as "artificial" and "foreign instigated," and the opposition's concerns about ethnic issues and “separatism," minority groups in Iran played a significant role in influencing Khatami's election campaign and the presidential election of 1997.

The focus of Khatami's presidential campaign was on the rule of law, democracy and inclusion of all Iranians in the political decision-making process. Khatami made a concerted effort to reach out to non-Persian and non-Shia constituencies. His supporters distributed election materials in Kurdish and Azeri, and Khatami campaigned on a pledge to expand the language rights of Iran's non-Persian minorities. ${ }^{402}$ This theme of inclusiveness and respect for differences featured prominently in his campaign slogan, "Iran for all Iranians," which implicated a major re-articulation of Iranian nationalism. Indeed, the support of minority groups was crucial to his two electoral victories. Alongside the youth and women, who were the primary supporters of Khatami, the ethnic minority participation in the 1997 elections showed the potential of these groups to make a difference in the democratic process in Iran. The support for Khatami in Iranian

\footnotetext{
${ }^{402}$ Shaffer, Brenda (2002). Borders and Brethren: Iran and the Challenge of Azerbaijani Identity, Cambridge, Mass.: MIT Press, 219.
} 
Kurdistan as well as in the other minority provinces was overwhelming and was clearly reflected in the election results.

One of the striking aspects of 1997 presidential elections in Iran was the overwhelming increase in the voter turnout compared to previous elections. The total voter turnout in 1997 elections was around eighty percent compared to 50.66 percent in the 1993 presidential elections, and 54.59 percent in $1989 .{ }^{403}$ Seventy percent of the voting population, roughly twenty million out of twenty-nine million voters, cast their votes in favor of Khatami, that is, in favor of democracy, civil rights and liberties. Both the increase in voter turnout over previous years and the margin of support for Khatami were significant indicators of the potency of the pro-democracy movement in Iran.

In the presidential election of 1997 , more than seventy percent of the population of ethnic regions voted for Khatami. This vast participation was a record in these areas. ${ }^{404}$ The level of popular participation in the elections in Kurdistan was itself very significant. The Kurds refused to participate in the referendum to ratify the Islamic identity of the post-revolutionary state, did not vote for the constitution of the Islamic Republic in 1979, and basically boycotted the previous presidential elections. The KDPI, which had boycotted the elections for about twenty years, encouraged the Kurdish people participate in 1997, and the change in Kurdish political participation behavior was remarkable. In the 1997 presidential elections, the voter turnouts in West Azerbaijan, Ilam, Kurdistan and Kermanshah - the provinces inhabited primarily by the Kurds in Iran - were 73.71

\footnotetext{
403 See Princeton University Iran DataPortal at http://www.princeton.edu/irandataportal/elections/ (Accessed September 14, 2012).

${ }^{404}$ Khorshidi, Majid, Zoeram, V. Amani Z, Fee, L. Yok, Jawan, Jayum A. (2011). "Politics of Ethnic Participation During Kahatmi’s Presidency in Iran (1997-2004)," Canadian Social Science, 7 (4): 148.
} 
percent, 87.16 percent, 79.04 percent and 75.15 percent, respectively. The voter turnout in these provinces in the presidential elections of 1993 and 1989 was much lower. ${ }^{405}$

A quick look at the voting behavior in other major minority provinces in 1997 elections shows similar results. Sistan and Balochistan, where the Iranian Balochs live, showed a voter turnout of 65.28 percent in the 1997 election, compared to 42.87 percent in the 1993 presidential election and 38.68 percent in the 1989 elections. Khuzestan, which is inhabited by a number of ethnic minorities, particularly the Arabs, showed a voter turnout of 74.08 percent in the presidential election of 1997 , compared to 45.60 percent in the 1993 presidential election and 59.02 percent in the 1989 election. ${ }^{406}$

The high participation in the 1997 elections in the minority provinces was the response of ethnic groups to Khatami's campaign mottos and inclusive statements. Although his support of ethnic rights might be viewed as a strategy to attract voters, Khatami's emphasis on democracy, rule of law and political participation was the result of ongoing pressure from minority political groups and political and civil rights activists in the ethnic regions. Even before the 1997 election, Iranian ethnicities were an important force for change in the status quo in Iran.

In their open letters to presidential candidates, both Azeri and Kurdish groups focus on the failure of the state to properly implement the Article 100 of the Constitution, which regulates the establishment of Provincial Councils for the management of local affairs. Although the idea of "councils" and administrative decentralization had been in

\footnotetext{
${ }^{405}$ The voter turnouts for the presidential election of 1993 in West Azerbaijan, Ilam, Kurdistan and Kermanshah are $48.80 \%, 66.26 \%, 54.96 \%$ and $52.57 \%$ respectively; and $55.23 \%, 85.39 \%, 58.68 \%$ and $53.20 \%$ in 1989 presidential elections.

${ }^{406}$ See Princeton University Iran DataPortal at http://www.princeton.edu/irandataportal/elections/
} 
Iranian constitutions since the constitutional revolution of 1906, it was never implemented because of the centrist approaches of both the Pahlavi and Islamic Republican states. The implementation of city and village councils was one of the most important of Khatami's campaign mottos. Moving towards decentralization and in response to the minority demands to run their own local social, cultural and economic affairs, Khatami announced the elections for the city and village councils less than one year after he took office. A national election, with active participation in the minority provinces, led to the creation of the councils in 1999.

The unelected power organs of the state, which were dominated by the conservatives, and internal conflicts within many city councils left them deprived of power, authority, and effectiveness. ${ }^{407}$ Despite their councils' marginal status in the decision making and administrative organs of the country, the implementation of the councils was very significant and an important first step towards the establishment of democratic institutions in Iran. The decision to strengthen local administration not only showed Khatami's strong will to respond to the minority demands but also the ethnic movements' capacity to shape state policies and improveme of the ethnic groups' participation in power.

After the election of hard-line Islamist Mahmoud Ahmadinejad to the presidency in 2005, the meager concessions of the Khatami era for ethnic minorities disappeared. Nonetheless, the ethnic factor never disappeared from the landscape of Iranian politics. Presidential candidates continued to place special emphasis on their slogans and promises concerning ethnic and religious minorities in the 2005, 2009 and 2013 presidential

${ }^{407}$ Tohidi, 317. 
elections as the ethnic movements continued to be an influential force in shaping the political agenda. Although the election of Ahmadinejad was seen as a sign that the movement for change in Iran had sunk into lassitude, civil unrest and opposition to the regime's policies continued in the ethnic regions, which became an increasingly important component of the growing civil society. Minority politics and ethnic mobilization provided a crucial social and political outlet for the growth of the prodemocracy oppositional movements in Iran. The vitality of developing a more inclusive approach to democracy that would address minority demands became evident again as another wave of reform emerged in the aftermath of 2009 presidential elections, showing signs that it would make a stronger push to achieve political change in the country.

\section{Presidential Election and the Second Wave of Reform}

The reform process that culminated in Khatami's presidency played a significant role in infusing democratic thoughts into society and strengthening liberal demands even though he had failed to realize many of his democratic promises. Iranian civil society had experienced an important period of rejuvenation during Khatami's presidency from 1997 to 2005. Preserving the advances of this period of reform became increasingly difficult after Ahmadinejad's rise to power, but the voices of civil society that had been gathering steam over the previous decade proved resilient and nudged the reform movement along even under conservative rule.

The 2005 presidential election closed the window of opportunity for democratic reforms. Events since then, however, suggest that the forces for democratic change in Iran continued to display considerable dynamism. Disputed results of the presidential election in 2009 triggered pro-democracy protests, but the protest movement had been in 
the making since the 2005 election. Developments on the minority rights front were particularly stirring.

In April 2005, the oil-rich Khuzestan province became the scene of severe ethnicrelated clashes. The uprising was against a government plan to alter the Arab composition of Khuzestan by transferring a great number of Arabs to other parts of Iran and replacing them with non-Arab ethnic groups, and changing the Arab names of various places and streets in the province to Persian names. ${ }^{408}$ Following the election of Ahmadinejad, the appointment of a Shia from Sistan as the governor of Balochestan, Habibollah Dehmordeh, who was known for his hard-line anti-Sunni Islamism, resulted in outrage among the Baloch and two Baloch deputies in the parliament resigned in protest. ${ }^{409}$ The same year, the Kurds took to the streets when the security forces killed and dragged the body of a Kurdish activist, Shawaneh Ghaderi, throughout Mahabad. Mass demonstrations took place in Kurdish towns and villages in July and August 2005, which resulted in an untold number of arrests and the deaths of at least seventeen people at the hands of security forces. ${ }^{410}$ In May 2006, a widespread campaign was organized by the Azerbaijanis following the publication of an insulting article by a state-sponsored daily. In February 2007, the Azerbaijanis marched in massive numbers in observance of the International Mother Language Day to protest the state-sponsored suppression of their heritage and language.

\footnotetext{
${ }^{408}$ Tohidi, 313.

${ }^{409}$ Ibid. 312.

${ }^{410}$ See Human Rights Watch, "Iran: Security Forces Kill Kurdish Protesters", August 11, 2005; Iran Human Rights Documentation Center (April 2012). "On the Margins: Arrest, Imprisonment and Execution of Kurdish Activists in Iran Today," 11-12.
} 
Similar to the Khatami era, ethnic factors continued to influence the presidential campaigns of the candidates in 2005 . The fact that massive riots and confrontations occurred in Khuzestan only two months before the election played an important role in prompting the candidates emphasizing the rights of ethnic and religious minorities in their slogans and promises. Both conservative candidates, such as Ali Larijani and Mohsen Rezai, and reformist candidates, such as Mustafa Moin and Mehdi Karrubi, visited the minority regions and made promises to implement the articles of the constitution regarding the cultural rights of the minorities and provincial councils.

The results of the 2005 election indicate the ethnic-related promises of the candidates were not received as favorably as they were in the presidential election of 1997. In the first round, the five provinces with the lowest turnouts were either Kurdish or Azeri regions. ${ }^{411}$ The rate of participation in the Kurdish cities was the lowest: nine percent in Mahabad, eleven percent in Bukan, twenty percent in Sanandaj, and fifteen percent in Mariwan. ${ }^{412}$ Increasing signs of alienation among the ethnic and religious minorities was one of the significant challenges Ahmadinejad had to cope with as president. Nevertheless, after a year in office, Ahmadinejad's intention to roll back the little progress that had been made during Khatami's presidency on minorities' rights and freedoms was clear. Banning Kurdish newspapers and imprisoning Kurdish activists

\footnotetext{
411 Sadjadpour, Karim (Summer 2005). "The Iranian Street in the Post-Khatami Era," in Middle East Program Occasional Paper Series, Iran After the June 2005 Presidential Election, Woodrow Wilson International Center for Scholars, 19.

${ }^{412}$ Quoted in Ahmadzadeh, Stansfield, 22; See www.dw-world.de/popup_printcontent/0,3118311,00.html
} 
became a common occurrence during Ahmadinejad's presidency. ${ }^{413}$ Following the 2005 demonstrations, the Iranian government forcibly closed down or banned more than 43 Kurdish publications, detained several Kurdish journalists and human rights, activists and forbid the study of the Kurdish language in universities. ${ }^{414}$

The post-presidential election protests in Iran in 2009 erupted against the officially declared victory of Mahmoud Ahmadinejad and grew into a major popular opposition movement, posing a great challenge to the country's power structure. This was a unique phenomenon not seen since the Iranian revolution that took place nearly 30 years ago. Just as the show of popular will and resistance through street protests brought down the Shah's regime in 1979, so the new protest movement, called the green movement, cast the divine authority of the Islamic Republic into a shadow of perpetual doubt. ${ }^{415}$ The green movement emerged as a result a sense of agency among different strata in Iranian society. While it was an important step in terms of moving the reform process forward in Iran, the green movement also underscored significant developments concerning the relations between diverse actors that constituted the pro-democracy movement.

First, the green movement crystallized the fact that the reformist leaders were no longer the only actors to shape the reform agenda in Iran. Different from the reform

\footnotetext{
${ }^{413}$ Courts have banned at least six daily and weekly bilingual Persian and Kurdish publications such as Payam-e Mardom (People's Message), Ashti (Befriend), Asu (Horizon), Rozhe Helat (East), Payam-e Kurdistan (Kurdistan Message), and Didgah (Viewpoint).

${ }^{414}$ Human Rights Watch. "Iran: Freedom of Expression and Association in the Kurdish Regions," January 9, 2009, 10-15.

${ }^{415}$ Monshipouri, Mahmood, Assareh, Ali (2009). "The Islamic Republic and the Green Movement: Coming Full Circle," Middle East Policy, 16 (4): 27.
} 
process during Khatami era, Iranian people who took to the streets in June 2009, were ahead of the political leaders of the green movement and reflected the increasing strength of Iran's emerging civil society. The leaders of the reform movement of the 1990s remained loyal to the Islamic movement, but rejected the conservatives' Islamic orthodoxy and fundamentalism and demanded, instead, the consolidation of democratic institutions. Given the absence of any discourse of democracy for nearly twenty years, Khatami's electoral campaign had led people to view him as the leader who could signal change and liberalize the political system.

The democratic discourse surrounding the green movement, on the other hand, was shaped by a sharper rejection of the existing political system and a deeper demand for structural changes. It explicitly underscored the contradictions associated with demanding democratic change within the framework of the many anti-democratic institutions fundamental to the Islamic Republic. Although they were recognized as leaders of the green movement, Mir Hussein Mousavi and Mehdi Karroubi, who were former high-ranking officials of the Islamic Republic, did not have a significant role in creating and organizing the movement and were only swept into power by a spontaneous wave of activism and the grass-roots movement.

Second, the loss of momentum the green movement suffered in the months following the election highlighted the drawbacks in the opposition's failure to develop an agenda that includes the demands of the ethnic minorities. Although the inhuman crackdown by the government security forces played a major role in suppressing the protests, a significant deficiency of the movement was its lack of widespread support from Iran's ethnic minorities, including the Kurds, Balochs, Arabs, Turkmen and others. 
The fact the protests remained limited to the northern areas of Tehran and a few more Persian cities considerably limited the green movement's struggle for power. As the ethnic minorities make up almost half of Iran's population, their reluctance to figure significantly in the protests restricted the green movement's potential to become a nationwide movement and painted it mostly an internal struggle or factional divisions of the Shia political elite.

The green movement was largely limited to Tehran and the peripheral ethnic minority-dominated areas that were under more pressure and exposed to greater discrimination remained silent. The green movement's unsuccessful campaign outside of Tehran was due in large part to the movement's leaders' lack of plans to include the Arabs, Azeris, Kurds and the Baloch, as well as the pro-democracy opposition groups' historical tendency to steer clear of direct contact with minority political groups. Wary about their status in the future of the movement, ethnic groups kept their distance from the protest movement despite the fact that they share most of the goals of the green movement such as increasing popular representation in government and opening Iranian society for greater internal political dialogue.

The discourse on ethnic politics expanded drastically during the 2009 presidential campaigns. Both of the reformist candidates, Mousavi and Karroubi, campaigned intensely in the minority regions to gain support from Iran's large ethnic and religious minority voting blocs. Mousavi, in particular, campaigned widely in the minoritydominated provinces of Azerbaijan, Khuzestan, Kermanshah, Mazandaran and Golestan and proposed detailed policies to address minority grievances in addition to standard assurances of respect for cultural rights and greater minority incorporation in 
government. Given the failure of the Khatami administration to bring about any sustainable changes to the status of ethnic groups in Iran, expectations remained low among Kurds and other ethnic groups that either reformist would have the political capital to implement the full range of their promises and change the authoritarian bent of the regime. The fact that pro-democracy reformists did not pay much attention to the human rights abuses of the Kurds during the first term of President Ahmadinejad played a significant role in dissolving the last remaining ties between the reform movement and ethnic minority demands.

Although demonstrations were not as widespread as in Tehran, minorities outside the capital did participate in protests pressing for their specific demands along with the green movement. However, given that no known formal or informal ties were ever established between the green movement's prominent politicians and minority political groups, it makes more sense to view the participation of ethnic minorities as a continuation of their long-term grievances and active opposition to the regime rather than a commitment to the green movement. The security and militarized atmosphere of the ethnic regions and the vulnerability of these areas to repressive activities by the regime are also factors that influenced the degree of minority participation in protests.

After the start of the protests in June 2009, many minority political groups expressed reluctance to put any faith in the Green Movement. The Kurdish Globe, an Erbil-based website affiliated with the Kurdistan Regional Government of Iraq, declared that the dispute between opposition leaders and the government was simply the latest of many internal power struggles among the political elites of Tehran, which have existed since the early years of the Islamic Republic. A new leader would not fundamentally 
change the government's position on minority rights or its human rights stand. ${ }^{416}$ The Kurdish political groups were reluctant to become involved with the green movement in any tangible way, opting instead for silence, or, at most, a statement of solidarity. In January 2010, the Democratic Party of Iranian Kurdistan issued a statement regarding the Kurdish movement's stance on the future of the green movement:

Democracy in its real form can only be obtainable when the national rights of the various nationalities are acknowledged explicitly. The Green Movement will succeed if it joins its cause with ethnic minorities. But that's something we believe the Green Movement is, so far, afraid to do. ${ }^{417}$

On June 7, 2010, Abdullah Mohtadi, secretary general of the Kurdish Komala Party, issued a statement aimed at forging solidarity between the Kurds and the green movement:

The people of Kurdistan do not demand special rights or benefits for themselves. They do not demand separation from Iran. Their demands are not outside the common framework of contemporary democratic regimes and recognized standards of human rights. The people of Kurdistan rightly demand that the effective leaders and political and cultural figures of the Green Movement and the practical activists of the movement, approve and support the demands of the people of Kurdistan, and in so doing allay their rather legitimate fears. ${ }^{418}$

Realization of the green movement's goals, by definition, includes the goals of many Iranian minority groups for increased self-expression and cultural autonomy. The reformist arguments for democratization and constitutional change, however, have largely left out appreciation and respect for ethnic and religious differences in the

\footnotetext{
${ }^{416}$ Ghajar, Shayan. "Iran's Minorities Look to Greens for Equal Rights," http://www.insideiran.org/criticalcomments/iran\%E2\%80\%99s-minorities-look-to-greens-for-equal-rights/ (Accessed March 22, 2013).

417 “The main Iranian Kurdish Party speaks to the Green Movement," Medya News, January 21, 2010.

${ }^{418}$ Mohtadi, Abdullah. "The Kurds and the Green Movement," Frontline Tehran Burau, available at http://www.pbs.org/wgbh/pages/frontline/tehranbureau/2010/06/the-kurds-and-the-green-movement.html (Accessed March 22, 2013).
} 
country. That said, throughout the green movement the Kurdish leadership was not very assertive in putting their case forward, but opted for silence. The green movement provided the Kurds with an opportunity to consolidate their position as the "third force" of democratization in Iran and integrate their demands into the emergent grassroots democratic front in the country. Although the Kurds criticized the green leadership's lack of an inclusive discourse to satisfy Iran's minorities, they did not make any real attempt to become a part of the protest movement by critically challenging the positions of both the regime and the reformists, and making their case.

The Kurdish movement in Iran is strong, but realizes its fate is intertwined with the Iranian opposition, as the minorities cannot overthrow the regime alone. Building alliances between the Iranian opposition and ethnic political groups depends on the ability of green movement to develop a more inclusive leadership who would approach the ethnic groups while ignoring the discourse of separatism. The establishment of mutual trust is possible only if a common discourse is formed with a common democratic agenda that genuinely includes the demands of the minorities.

\section{The Kurds and the Iranian Opposition: New Horizons for Cooperation}

The green movement has done more to rock the foundation of the Islamic Republic than three decades of sanctions and containment imposed by the U.S. and the United Nations. Since its inception, the Islamic Republic pursued a policy of harboring nationalist sentiments in Iran by referring to the "external enemy" argument as a method of avoiding intractable internal problems. The reformist process that started with the Khatami era and continued with the 2009 green movement has significantly challenged this policy by bringing the internal problems of Iran to the attention of both domestic and 
international actors. Although the regime managed to suppress the protests of June 2009, the green movement or the pro-democracy movement in Iran should be regarded as an ongoing political project rather than a failed attempt to challenge the government. In this regard, while the regime appears unyielding, the political and moral victories Iran's reform movement has achieved is beyond dispute and are likely to propel further efforts for democratic change.

While the regime's violent crackdown on activists in 2009 widened the gap between ethnic minorities and the regime, the reformists' failure to effectively confront the conservatives and challenge the status quo was disappointing for the minority political groups. Since the repression of the protest movement, the Iranian opposition and minority groups held a number of meetings under the name, "Unity for Democracy in Iran," in an attempt to unite the opposition and strengthen the green movement. The first sitting of the conference took place on February 4-5, 2012, in Stockholm, Sweden, where the participants discussed the political conditions in Iran, and methods to establish democratic rule, free elections and the future of minorities. To implement the recommendations of the Stockholm conference, a second meeting of the movement convened in Brussels on July 7-8, 2012, which proposed a further extension of the membership of the conference. Finally, on November 17-18, 2012, a third conference was held in Prague, which addressed the issues of unity within the Iranian opposition, the plight of women, and the political demands of the various nations living within Iran's borders.

Kurdish opposition leaders stressed the importance of achieving a federal democracy in Iran in order to accommodate the political demands of the minorities living 
within Iran's borders. In the last meeting, which was held in Prague, Hassan Sharafi, the Deputy Secretary General of the KDPI, and Abdullah Mohtadi, leader of Komala Party of Iranian Kurdistan, highlighted the importance of genuine and frank dialogue among various opposition groups and underscored that denying the multinational character of Iran and describing it as a country consisting of one nation is contrary to reality. ${ }^{419}$ Although the opposition groups showed a general reluctance to address and respond to the Kurdish demands for a democratic federalist state as an alternative to the Islamic Republic, the meetings provided the Kurds with a chance to express their views and show they are a strong and active part of the Iranian opposition. Considering the decades-long separatist stigma attached to the minority political groups in Iran - particularly, the Kurdish parties - the fact the Iranian opposition groups took part in the meetings and listened to the aspirations of the Kurds was itself a sign of progress and a growing awareness on the part of all groups that ethnic demands in Iran need to be addressed.

After the protest movement of 2009 , both the green movement leadership and the Iranian opposition showed signs of willingness to compromise and work with ethnic groups. As a daring move, Mir Hussein Moussavi released a statement on May 10, 2010, condemning the "unjust" executions of five Kurdish activists by the Iranian judiciary. Moussavi's remarks particularly surprised the hardliners in the Iranian government who did not expect the leader of the green movement to take an anti-government position on a

419 "PDKI participated in an Iranian opposition meeting in Prague," November 22, 2012, http://pdki.org/english/pdki-participated-in-an-iranian-opposition-meeting-in-prague/ (Accessed March 25, 2013). 
topic deemed sensitive even by the members of the Iranian opposition. ${ }^{420}$ Likewise, in a statement issued on January 15, 2013, the Coordination Council of the Green Path of Hope, an important body within the opposition movement, voiced its criticism of government measures aimed at curbing the use of Kurdish at schools in the province of Kermanshah. The Coordination Council stated that the move was a clear breach of article 15 of the Iranian constitution, which allows for the use of local languages in press, media and the education system, and such actions are against human rights norms and the will of the majority of Iranians from all ethnicities, languages and religions. ${ }^{421}$

The eleventh presidential election in Iran, which was held on June 14, 2013, renewed hopes for the Kurds and the other ethnic groups for greater rights for Iran's minorities. Newly elected President Hassan Rouhani’s election motto was “moderation and change." He was the only candidate who promised to ensure the cultural and language rights of minority groups, and assist in the return of Iranian Kurds living abroad. $^{422}$ Rouhani won the votes of seventy percent of fifty million eligible voters in Iran. ${ }^{423}$ His campaign pledge during to work for minority rights and include minorities in his administration resulted in a high voter turnout in favor of Rouhani in major Kurdish

\footnotetext{
420 "Moussavi Takes Political Risk and Condemns Kurdish Executions," May 11, 2010, http://insideiran.org/media-analysis/moussavi-takes-political-risk-and-condemns-kurdish-executions/ (Accessed March 25, 2013).

421 “Iranian Opposition Slams Limitations On Use Of Minority Language In Schools,” January 19, 2013, http://en.irangreenvoice.com/article/2013/jan/19/3914 (Accessed April 24, 2013).

422 “Kurdish Vote Contribute to Rouhani’s Victory in Iran,” Rudaw, June16, 2013.

423 “Rouhani Wins Iran's Presidential Election,” Al Jazeera, June 15, 2013.
} 
populated provinces such as West Azerbaijan, Kermanshah and Kurdistan. ${ }^{424}$ However, the hopes of the Kurds and other minorities for greater rights in Iran were soon dashed when Rouhani, immediately following his election victory, stated in a television interview that Iran is "not a multi-ethnic state" and that "there is only one nation in Iran and that is structured by Islamic system." ${ }^{425}$

It might be too early to judge Rouhani's attitude towards the ethnic question in Iran, but his rhetoric so far displays continuity rather than a break with the policies of previous administrations. Voting patterns since the establishment of Islamic Republic show that ethnic groups turn out to vote in higher numbers for the candidates who support their rights. The reformists, however, have failed to improve minority rights in Iran, and the Kurds' already skeptical attitude towards the election system in the country has deepened and since the Khatami era, led to consistently lower rates of Kurdish voter turnout compared to other provinces in the country. Lower rates of turnout in provinces where non-Persian ethnic groups are concentrated indicate a strong "rejectionist" sentiment towards the political system in general. Before the 2013 elections, in an interview with BBC Arabic, Khalid Azizi, secretary general of the Iran's Kurdistan Democratic Party (IKDP), said that:

The elections and their outcome would not change anything for the people of Iran. These elections aren't about human rights or the rights of the Iranian people. It is a way for the Iranian regime to come out of its

\footnotetext{
${ }^{424}$ The results of $11^{\text {th }}$ Presidential Election in Iran by provinces are available at http://www.moi.ir. For an English source see Princeton University Iran Data Portal at http://www.princeton.edu/irandataportal/ elections/ (Accessed June 22, 2013).

425 "Rouhani Comments in Iran Surprise Kurds, Other Minorities," Rudaw, July 4, 2013.
} 
own crisis. People participate only to find a solution for the economic crisis the regime has got them into. ${ }^{426}$

Unless the deep-rooted flaws embedded in the core institutions of representative democracy in Iran are eliminated, a regime change would be unlikely to change the political and social positions of ethnic or religious minorities in Iran. It has been shown time and again, be they reformist or conservative, successive regimes in Iran have refused to recognize the multi-ethnic reality of the country and the legitimate rights of the minorities. That is why it is imperative for the Kurds and other pro-democracy forces in Iran to collaborate under the common theme of systemic political change. Political developments since Mohammad Khatami's presidential victory in 1997, and the corresponding rise of the reform movement reveal that the ethnic dimension of Iranian politics is the country's most revolutionary force. Many Iranian officials, religious leaders, and intellectuals, particularly those associated with the reformist movement, have gradually come to realize that Iran's ethnic minorities have significant potential to wield power in terms of challenging the regime. This growing awareness concerning the capacity of ethnic groups might propel further rapprochement between the opposition and the minority political groups. Within this framework, the incorporation of the perspectives of Iran's different ethnic groups into the reformist agenda may constitute an important part of the evolution of the green movement.

\section{The International Dimension of the Kurdish Question in Iran}

The internationalization of the Kurdish issue that affected three parts of Kurdistan since the early 1990s, in Iraq, Turkey and Syria, may appear to have bypassed the Kurds

\footnotetext{
426 “Kurdish Vote Contribute to Rouhani’s Victory in Iran,” Rudaw, June 16, 2013.
} 
of Iran. Even though the Iranian Kurdish movement seems to be politically dormant in recent years compared to the Kurdish movements in Turkey, Iraq and Syria, the Kurds in Iran have never stopped opposing the country's successive governments and have always maintained the potential for profound change in Iran. ${ }^{427}$

The toppling of Saddam Hussein's regime in Iraq in 2003, the EU accession process of Turkey, the expansion of the PKK movement beyond Turkey's borders and the dramatic developments taking place in Syrian Kurdistan resulted in increased world attention to the Kurdish movements in Iraq, Turkey and Syria. The Kurds of Iran, on the other hand, have been isolated internationally, and lack allies outside the country. The establishment of political ties between external actors and Iran's ethnic movements to support political change in Iran is not very likely at the moment. The sheer size of Iran, in terms of both territory and population, the stability of the regime, and the support base the regime has among the Shia conservatives make it quite challenging for any outside actor to intervene in Iran. Unlike Iraq and Syria, which are weak states and had been ruled by minorities, Iran is ruled by its largest ethnic and religious group, the Shia Persians, supported by the tradition of a strong and bureaucratic state.

That said, the Iranian regime has its own vulnerabilities. Iran is extremely troubled by the regional uprisings, particularly in Syria. Given the long-term strategic alliance between Iran and the Assad regime, the prevalent view concerning the possible consequences of Assad's overthrow in Syria is that "when Assad is defeated it is the turn of Iran." Therefore, Iran has supported Bashar Al-Assad at all costs. Should Assad's

${ }^{427}$ Bengio, Ofra. “A Kurdish Awakening in Iran,” Haaretz, October 26, 2012. 
regime collapse, Iran will lose its most important ally in the region with significant repercussions for its own Kurdish population. Should the upheavals reach Iran, the Iranian Kurds are likely to be the pioneers of change along with the other minority groups and pro-democracy forces in the country.

In the meantime, the synergy of cooperation among the Kurds of Iran as well as with Kurds in other parts of Kurdistan is increasing rapidly. The Iranian Kurds have benefited from the pan-Kurdish spirit developing in the Kurdistan Regional Government of Iraq, closely watching the ongoing peace talks between the PKK and the Turkish government and following the inspiring developments taking place on the Syrian Kurdish political scene. In August 2012, two major Iranian Kurdish parties, KDPI and Komala, signed a cooperation agreement that raised hopes for a united Iranian Kurdish front. It was declared that the agreement would not only be the basis for collaboration between the two parties in policy, diplomacy and media, but also serve as a basis for more cooperation among the other Kurdish political forces in Iran. ${ }^{428}$

A few months later, in December 2012, the KDPI and Iran's Kurdistan Democratic Party (IKDP) met for the first time since splitting in 2006 for talks at possible reunification. At a 2006 convention, KDPI members elected Mustafa Hijri as the leader of the KDPI, which led to a split in the party that created IKDP under the leadership of Khalid Azizi. ${ }^{429}$ Although the meeting did not result in the conclusion of an official

\footnotetext{
428 "Kurdish Parties of Iran Sign Cooperation Agreement," Ak News, August 22, 2012.

429 "Iranian Kurdish Parties KDP, KDPI Meet for First Time since 2006 Split," Rudaw, December 14, 2012.
} 
agreement for reunification, it marked an important step towards reconciliation and reaching a common settlement.

Finally, in July 2013, thirty-nine Kurdish political groups from all parts of Kurdistan gathered in Erbil, Iraq, under the auspices of the Kurdistan Regional Government for preliminary talks to organize a Kurdish National Conference. This became an important unifying factor for the Iranian Kurdish parties, particularly the three different branches of the Komala Party. Since its foundation, Komala has gone through several divisions due to ideological differences. The planned National Conference made a significant impact on bringing together Komala's three factions to win a seat at the conference and improved the dialogue between all groups working under the name, Komala. The preliminary talks on the organization of the conference also played an important role in toning down the tension between the Party of Free Life of Kurdistan (PJAK) and the other Kurdish parties in Iran by creating a common ground of action. PJAK, since its establishment in 2004, gained significant popular support among the Kurdish youth in Iran and managed to capture the attention of the world with its guerilla actions against the Iranian regime. Nevertheless, the party's affiliation with the PKK has always strained the relations between PJAK and the other major Kurdish parties in Iran.

In an interview following his party's cooperation agreement with Komala, Mustafa Hejri, Secretary General of the KDPI, observed that the agreement was made in preparation for the collapse of the Iranian regime. ${ }^{430}$ The creation of a common ground of action is crucial in order for the Kurdish political groups to effect change in Iran.

430 "KDPI Leader: Agreement with Komala is Preparation for Collapse of Iranian Regime," Rudaw, September 5, 2012. 
Overcoming internal divisions is important for the Iranian Kurds so they can enhance the status of the Iranian Kurdish movement as a strategic partner in the eyes of both the Iranian opposition and international actors. Considering the possibility that the ongoing revolutionary wave in the Middle East might reach Iran, it is imperative the Iranian Kurds reduce their own internal conflicts and develop a strategic plan to improve their situation in the event Iran, too, undergoes a process of political change in the future.

\section{CHAPTER VII}

\section{CONCLUSION}

Since the early 1990s, the Kurdish national movements in Turkey, Iran, Iraq and Syria have undergone important political and ideological transformations that created multiple and intertwined layers of domestic and foreign policy considerations in each country. The most significant aspect of this transformation process is the incorporation of "democratic discourse" into the movement's objectives and the resulting reconceptualization of Kurdish nationalism. The democratic discourse is characterized by demands for recognition of the multi-ethnic and multi-cultural nature of the countries in which the Kurds live, and by requests for an inclusive definition of citizenship that would transform the ethno-national hierarchies and pave the way for redistribution of power and sovereignty on an equal basis. Within this framework, over the past two decades, the Kurdish national movement has acquired a dual character: it is at once an ethno-cultural struggle for the recognition of Kurdish identity and demands, and also a democratization 
movement that seeks to redefine the concepts of governance and citizenship in Turkey, Iran, Iraq and Syria.

There has been a significant realization within the Kurdish movement that the preservation of their ethnic identity and culture can be possible only within a democratic polity. From this perspective, the struggle for an ethno-cultural identity and the struggle for democracy have become closely intertwined and it is not possible to win one without winning the other. In line with this reconceptualization of Kurdish nationalism, the Kurds began to play an increasingly important role in shaping the debates on governance, human rights and democratization in Turkey, Iran, Iraq and Syria starting in the early 1990s. In this context, the Kurds' role as ethnic actors has been largely transformed into one that is centered on the Kurds as "democratic agents" who influence the relationship of the Kurds to their respective central governments in significant ways. These observations raise four questions: (1) Under what conditions have the Kurds become agents of change for democratization? (2) Why did this role become particularly visible in the 1990s? (3) How does this role affect the political systems of the countries in which the Kurds live? (3) How does the adoption of the "democratic discourse" impact the transnational aspect of the Kurdish movement?

While the Kurdish movements acting in the different parts of Kurdistan share a number of common characteristics, the answer to each of these questions unfolds differently in Turkey, Iran, Iraq and Syria due to the fact that each of these countries has a distinct political and ideological structure, which interacts with the regional and international dynamics in different ways. Three factors have the strongest explanatory power in accounting for the first question: the size and geographical location of the 
Kurds; the use of political violence for the accomplishment of Kurdish nationalist goals; and the definition of Kurdish question as a problem of "democracy" rather than a problem of "statelessness."

The Kurds comprise a sizable portion of the population in each of the four countries in question and this provides them with a the capacity to influence the domestic politics of the countries in which they live and put pressure on their respective central governments to effect political change. The Kurds are also a geographically concentrated group, mostly inhabiting a region known as Kurdistan. The fact that they live predominantly across the borders of each of the four countries in question creates an important opportunity for engaging in cross-border activity. This situation underscores the fact that the Kurds are not only a domestic, but also a foreign policy concern for Turkey, Iran, Iraq and Syria.

The size and geographical location of the Kurds become significant for their role as democratic agents particularly in the context of the Kurdish movements' use of political violence to achieve their goals. Armed struggle was seen by the majority of the Kurds as the only viable way to create an effective political struggle and to force the central governments to a solution because of the highly authoritarian structure of all the four countries in which the Kurds live. In this respect, Turkey can be considered as an exception due to its more open political system as compared to the other three countries. This was the main reason why the Kurds in Turkey initially embraced political struggle in the 1960s and 1970s, yet felt obliged to turn to armed struggle when it became apparent there were no sufficient political avenues available to force the Turkish state to consider a negotiated settlement. 
The link between armed struggle and democratization is more visible in Turkey and Iraq than in Iran and Syria because of the proportion of Kurds among the total population in Turkey and Iraq is considerably higher as compared to Syria and Iran. This situation influences not only the potential number of recruits for the guerilla forces, but also the number of people who can be politically mobilized through armed struggle. Both in Turkey and Iraq, masses followed the PKK, the PUK and the KDP because of their capacity to successfully challenge the military forces of their respective central governments. In both countries, armed struggle played a significant role in mobilizing the Kurds and opening space for the political struggle, which made it considerably difficult for both Turkey and Iraq to ignore the Kurdish demands. Given the strong military capacity of the Kurdish movements in both Iraq and Turkey, the armed conflict became protracted in both countries, which made the political costs of ignoring the demands of the Kurds increase and put pressure on the central governments to open negotiations to find a political solution. These processes of negotiation encouraged both democratization and the peaceful settlement of the Kurdish question in Iraq and Turkey.

In Iran, on the other hand, the armed struggle of the Kurds did not bring the same results for a number of reasons. Iranian Kurds are a sizable minority in Iran like the Kurds in Iraq and Turkey, but the Kurdish parties in Iran never managed to develop a military capacity as strong as their counterparts in Turkey and Iraq. The armed confrontations between the Kurds and the Iranian regime often resulted in brutal suppression and the defeat of the Kurdish movement. While Iranian Kurds always maintained their organizational capacity to revive and challenge the regime, this only led to an intermittent war rather than the protracted battle that tormented the Turkish and 
Iraqi governments and made it difficult to ignore the Kurds' demands. In other words, the political costs of ignoring the Kurds' demands never became high enough for the Iranian regime to open negotiations to implement concrete political changes.

Armed struggle did not play a major role in mobilizing the Kurdish populations in Iran politically as it did in Turkey and Iraq. After each defeat, resources were used to revive the armed struggle, which prevented the emergence of a strong pro-Kurdish political opposition in Iran. Another factor that influenced the Kurdish movement in Iran is the Sunni-Shia divide - the most significant factor that determines the policies of inclusion and exclusion in the country. Different from the Kurds in Iraq and Turkey who were able to mobilize around the common theme of "ethnic unity," the Kurds in Iran were vulnerable to the cooptation policies of the Iranian government on the basis of sectarian divides.

In Syria, the relatively smaller number of the Kurds within the total population considerably reduced the capacity of the Syrian Kurds to develop a strong movement either politically or militarily. The cross-border activities between the Kurds worked both against and in favor of the Syrian Kurds. The fact the Kurdish movements in Turkey and Iraq cooperated with the Syrian regime worked against the formation of an autonomous Syrian Kurdish movement until the early 1990s. However, that the Kurdish parties of Turkey and Iraq had relative freedom of action in Syrian Kurdistan was a positive contribution to the development of national consciousness among the Kurds of Syria. This situation not only increased Kurdish political mobilization in Syria in the 1990s, but also prompted the emergence of the Kurdish movement as a key actor in the Syrian uprising since 2011. 
The definition of the Kurdish question as a problem of "democracy" rather than a problem of "statelessness" considerably increases the chances of a negotiated settlement. The use of political violence, and the size and geographical location of the Kurds plays an important role in bringing the Kurdish question to the attention of the central governments of Turkey, Iran, Iraq and Syria. However, these factors also give the central governments the opportunity to disregard the Kurdish movements on grounds The Kurds are "separatists" and "terrorists." The perception of the Kurds as separatists and terrorists automatically eliminates the possibility of reaching a negotiated settlement and prolongs the war. Therefore, it is considerably important that the "democratic discourse" be consistently incorporated into the official party programs and political activities so as to create incentives for the central governments to respond to the armed struggle and come to the negotiation table.

The Kurdish movement in Turkey has repeatedly emphasized a democratic discourse in defining its goals since the early 1990s. Over the years, the goals of the PKK were defined and redefined in the official party programs through different formulations proposed by Öcalan, including "democratic unity," "democratic civilization," "democratic republic," "democratic confederalism" and "democratic autonomy." Each of these proposed solutions was based on respect for the territorial integrity of Turkey and the idea of a peaceful coexistence between the Kurds and Turks on an equal basis within a democratic polity. Democratization in Turkey cannot be analyzed without giving due consideration to the role these concepts had in influencing both public opinion and the political agenda in Turkey. 
In their negotiations with the successive regimes of Iraq, Iraqi Kurds always repeated their main motto, "autonomy for Kurdistan, democracy for Iraq." This formulation became even more significant after the establishment of the Kurdistan Regional Government in 1991, as the external support for the Iraqi Kurds was, for the most part, tied to an international commitment to the territorial integrity of Iraq. By remaining part of Iraq, the Iraqi Kurds not only consolidated their autonomous status, but also influenced the process of democratization in the country, especially after the American-led invasion in 2002.

In a similar vein, both the Iranian and Syrian Kurds always mainstreamed the discourse of autonomy and cultural rights while defining their goals since the 1990s. Their demands played a significant role in influencing the agenda of a number of important political opposition movements in both countries such as the Damascus Spring and the 2011 uprising in Syria and the reformist movement and the 2009 Green movement in Iran.

The role of the Kurds as "democratic agents" became particularly visible in the 1990s. This dynamic can be explained by considering both regional and international factors. The Kurdish movements in each of these four countries were affected by socialist ideas throughout the Cold War due to the appeal of Marxism-Leninism by the oppressed and marginalized groups. However, socialism's uneasy relationship with nationalism made it difficult for the Kurds to reconcile socialist ideology with their national liberation discourse. Moreover, the position taken by the Soviet Union as well as the post-Cold War Russia towards the Kurdish question was generally in the form of supporting the Kurds' central governments because of strategic interests. This situation prevented the 
establishment of strong alliances between the socialist groups and the Kurdish nationalist groups throughout the Cold War with the exception of Turkey. Until the end of the Cold War, although the majority of the Kurdish parties declared their commitment to the emancipatory values of socialist ideology, it was Kurdish nationalism that was the prominent ideological force in defining the movement's goals. As a result, the Kurdish movement figured predominantly as an ethnic actor, which limited its appeal to ethnic Kurds.

In the early 1990s, the collapse of the Soviet Union and the global turn to "democracy" affected the Kurdish movement. As the center-left and socialist groups were left without an identifiable political project in the post-Cold War era, the discourse of human rights and democracy provided the Kurdish movement with an opportunity to add a universal appeal to its demands for decentralization and cultural rights. Throughout the twentieth century, the lack of international support was one of the biggest political handicaps of the Kurdish movement. By adopting the democratic discourse in the postCold War era, the Kurds attempted to remove this handicap. The discourse of human rights and democracy contributed to the establishment of ties between the Kurdish movements and external actors, particularly in the case of Turkey and Iraq.

The debate on Kurdish rights greatly influenced the political reforms implemented in Turkey within the framework of Turkey's EU accession process. The Iraqi Kurds, on the other hand, have become the most ardent supporters of the promotion of democracy in Iraq after the establishment of the KRG in 1991, given the close relationship between Iraq's democracy and consolidation of the autonomous status of the Kurds. Because of the highly authoritarian and closed nature of the political systems in Iran and Syria, the 
Kurdish organizations there have not managed to gain direct access to external actors. However, a strong emphasis on the discourse of human rights and democracy enabled the Kurdish groups to establish alliances with other pro-democracy groups within their respective political environments, and expanded the appeal of the Kurdish movement beyond the ethnic Kurds.

The greatest impact of the Kurds' role as democratic agents in Turkey, Iran, Iraq and Syria has been the challenge it posed upon the nation-state system. The Kurds' demands for the recognition of the multi-ethnic and multi-cultural structure of the countries in which they live have shaped important debates on democracy, governance and citizenship in Turkey, Iran, Iraq and Syria since the early 1990s. In Turkey, the Kurdish movement shapes such important debates as the strengthening of local administrations in accordance with the EU criteria, and changing the constitution to establish a more inclusive conception of citizenship and education in the mother tongue. In Iraq, the autonomous Kurdish rule not only translates into democracy for the people of Iraqi Kurdistan, but also offers the best way to keep Iraq together and democratic through decentralization and power sharing. In Iran, the Kurdish movement is the most influential actor in terms of the expression of minority demands in the country and has the strongest potential to successfully democratize Iran should similarly situated minorities and/or other pro-democracy forces join it. The Syrian uprising, which has been ongoing since 2011, is the first serious possibility of democratic change in Syria. In the context of the fierce struggle for power between the Assad government and the Islamist forces, the Kurdish parties in Syria currently offer the best democratic alternative and are evidence 
that democracy in Syria cannot be achieved without accommodating Kurdish identity and demands.

How the Kurds' emergent role as democratic agents affects the transnational aspect of the Kurdish question is crucial not only for the countries with sizable Kurdish populations, but also for the entire Middle East. It can be argued that since the 1990s the Middle East has witnessed the emergence of a new conception of "Greater Kurdistan" defined by the goal of establishing decentralized polities across Turkey, Iran, Iraq and Syria, which would strengthen the political and cultural interaction between the Kurdish communities living in different countries and render national borders less significant. The broader implication of the new conception of Greater Kurdistan is that it offers an alternative institutional framework to the current state system in the Middle East, a system that is more suitable to the current era of democratization. As an alternative to the highly centralized and elitist political structure that prevails in the Middle East, the Kurdish movement proposes a new political framework that would result in an open, participatory and plural democratic society.

Today, the Kurdish political situation in the Middle East is largely dominated by political rivalry between Öcalan and Barzani. While this rivalry is usually portrayed in the scholarly and policy circles as an indication of the fragmented nature of the Kurdish movement, it actually suggests a growing understanding among the Kurdish parties regarding the rules of political competition. One of the major weaknesses of the Kurdish movement throughout the twentieth century was that the Kurds fought with each other as much as they fought with their central governments. Bloody episodes of civil war occurred in Iraq between the KDP and PUK, and armed confrontations between the PKK 
and KDP played a significant role in damaging "Kurdish unity" in the Middle East. This new conceptualization of Greater Kurdistan not only offers an alternative institutional framework for the Middle East, but it redefines the concept of "Kurdish unity" within the framework of respect for the individual characteristics of Kurdish movements in each part of Kurdistan. Currently, the political competition between the Kurdish movements in Turkey and Iraq can be observed in the Syrian context. However, there has also been substantial agreement to avoid infighting among Kurdish groups and to resolve disputes through regional meetings. The Kurdish meetings that took place in Erbil during the course of the Syrian uprising should be seen in this light.

The most significant manifestation of the Kurds' increasing role as democratic agents in the Middle East is the emergence of the Kurdish movements as a "third force" in each of the four countries in question. Without the Kurdish dynamic within their respective political systems, Turkey, Iran, Iraq and Syria have a lesser chance of becoming true democracies. The Kurdish movements in each country act as important opposition groups by shaping debates over political change. However, what makes the Kurdish groups key actors in this process is that instead of bandwagoning, they playoff both the regimes and the main opposition groups. The Kurdish movements take the "third player" position vis-à-vis the ongoing power struggles between the Shia and Sunni Arabs in Iraq, the moderate Islamists and Kemalists in Turkey, the conservatives and reformists in Iran, and the Assad regime and Islamist opposition in Syria.

The Kurds" position as the "third players" derives directly from the way they incorporate the democratic discourse within their political objectives. While the regime and opposition in Turkey, Iran, Iraq and Syria are in a fierce struggle for power, they 
make common cause regarding the protection of the nation-state and the denial of the ethnic diversity of their respective societies. Hence, from the perspective of the Kurds, regime change, defined as the replacement of one administration or government by another, will not lead to genuine democracy in any of the four countries as long as the exclusionary character of the nation-state system remains intact. What is suggested by the Kurdish movement instead is the need for a structural transformation of the political systems of Turkey, Iran, Iraq and Syria that would transform the prevailing ethnonational hierarchies by redistributing political power and sovereignty on an equal basis.

A wave of popular pro-democracy protests has swept through the Middle East since late 2010 and led to important political transformations in the region. However, three years after the outbreak of what is now referred to as the Arab Spring, the fledgling democracies of the Middle East face great uncertainty. Despite the toppling of old authoritarian regimes in a number of Arab countries and the widespread aspiration for change, the state of human rights and democracy in the region remains dire. One of consequences of the disintegration of the authoritarian regimes is they set the stage for communal strife along ethno-sectarian lines as it was seen in Egypt, Libya, Yemen and increasingly in Syria. The long-term distrust and bitterness built up under the centralized, authoritarian nation-states of the Middle East has become a significant barrier to the establishment of genuine democracies in the region.

The experience of the Kurds indicates that the Middle East's multi-ethnic and multi-sect reality needs to be considered not as a "problem," but as a matter of "pluralism" and "democratic participation." By raising claims for a competing vision of culture, governance and political representation, the Kurdish movement rejects the 
concept of nation-state. Instead, it offers the establishment of decentralized governments as an alternative institutional framework to address the problems facing the multinational states of the region and to achieve open, participatory and plural democratic societies. Given that the nation-state constitutes a fundamental problem for the "identity" demands in the Middle East, such a perspective has important implications not only for the countries with significant Kurdish populations, but for the wider debate on regime change and democratic transition in the region. 


\section{BIBLIOGRAPHY}

Ahmadzadeh, Hashem (2010). "Kurdish Political Mobilization in Iran" in The Kurdish Policy Imperative edited by Robert Lowe and Gareth Stansfield, London: Royal Institute of International Affairs.

Ahmadzadeh, Hashem, Stansfield, Gareth (Winter 2010). "The Political, Cultural and Military Reawakening of the Kurdish Nationalist Movement in Iran," The Middle East Journal, 64 (1): 11-27.

Ahmed, Mohammed M. A. (2007). "Laying the Foundation for a Kurdistani State in Iraq: 1991-2006" in The Evolution of Kurdish Nationalism edited by Mohammed M. A. Ahmed, Michael Gunter, Costa Mesa, CA: Mazda Publishers.

AKP Party Program (2001). http://www.akparti.org.tr (Accessed March 3, 2012).

Ali, Othman. "The Struggle for the Hearts of Kurds in Syria: Barzani vs. Öcalan," Today's Zaman, February 13, 2012.

Al-Marashi, Ibrahim, Salama, Sammy (2008). Iraq's Armed Forces: An Analytical History, New York: Routledge.

Al-Rikabi, Ramsey. "The Kurds and the Constitution," Al-Ahram Weekly, March 18, 2004.

Amnesty International, "Iraq: Hope and Fear; Human Rights in the Kurdistan Region of Iraq," April 14, 2009.

Amnesty International. “Days of Rage: Protests and Repression in Iraq,” April 12, 2011.

Amnesty International. "Iran: Human Rights Abuses against the Kurdish Minority," July 30, 2008.

Amnesty International. "Kurds in the Syrian Arab Republic One Year after the March 2004 Events," March 10, 2005.

Anderson, Liam (2008). "The Non-Ethnic Regional Model of Federalism: Some Comparative Perspectives" in An Iraq of Its Regions: Cornerstones of a Federal Democracy edited by Reidar Visser, Gareth Stansfield, New York: Columbia University Press.

Arango, Tim. "Kurds Prepare to Pursue More Autonomy in a Fallen Syria," New York Times, September 19, 2012. 
Arendt, Hannah, Kohn, Jerome (ed.), Felman, Ron H. (ed.) (2007). The Jewish Writings, New York: Schocken Books.

Atabaki, Touraj (2000). Azerbaijan: Ethnicity and the Struggle for Power in Iran, London: I. B. Tauris Publishers.

Bahcheli, Tozun, Noel, Sid (2011). "The Justice and Development Party and the Kurdish Question," in Nationalisms and Politics in Turkey: Political Islam, Kemalism and the Kurdish Question edited by Marlies Casier, Joost Jongerden, London and New York: Routledge.

Ball1, Rafet (1991). Kürt Dosyası (Kurdish File), İstanbul: Cem Yayınevi.

Barakat, Sultan (2005). "Post-War Reconstruction and Development: Coming of Age" in After the Conflict: Reconstruction and Development in the Aftermath of War edited by Sultan Barakat, London: I. B. Tauris.

Barkey, H. and G. E. Fuller (1998). Turkey's Kurdish Question, Boston: Rowman \& Littlefield.

Barkey, Henri (1996). "Under the Gun: Turkish Foreign Policy and the Kurdish Question," in The Kurdish Nationalist Movement in the 1990s: Its Impact on Turkey and the Middle East edited by Robert W. Olson, Kentucky: The University Press of Kentucky.

Beck, Lois (May, 1980). "Revolutionary Iran and Its Tribal Peoples," MERIP Reports, no. 87.

Beiner, Ronald (2003). Liberalism, Nationalism, Citizenship: Essays on the Problem of Political Community, Vancouver: UBC Press.

Bengio, Ofra (2005). "Autonomy in Kurdistan in Historical Perspective" in The Future of Kurdistan in Iraq edited by Brendan O'Leary, John McGarry, and Khaled Salih, Philadelphia: University of Pennsylvania Press.

Bengio, Ofra (November/December, 2012). "Will the Kurds Get Their Way?," The American Interest.

Bengio, Ofra (Summer 2003). "Iraqi Kurds Hour of Power," Middle East Quarterly, 10 (3): 39-48.

Bengio, Ofra. “A Kurdish Awakening in Iran,” Haaretz, October 26, 2012.

Beşikci, Ismail, (1992). Doğu Mitinglerinin Analizi (Analysis of the Eastern Meetings), Ankara: Yurt Yayınevi 1992. 
Birand, Mehmet Ali, "Turkish Public Opinion is Softening towards the Kurds," International Herald Tribune, July 8, 1999.

Bozarslan, Hamit (2003). "Kurdish Nationalism in Turkey: From Tacit Contract to Rebellion (1919-1925)" in Essays on the Origins of Kurdish Nationalism edited by Abbas Vali, Costa Mesa, CA: Mazda Publishers.

Bozarslan, Hamit (2004). Violence in the Middle East: The Political Struggle to Self Sacrifice, Princeton: NJ: Markus Wiener Publishers.

Bozarslan, Hamit (2007). "Kurdish Nationalism under the Kemalist Republic: Some Hypotheses," " in The Evolution of Kurdish Nationalism edited by Mohammed M. A. Ahmed and Michael Gunter, Costa Mesa, CA: Mazda Publishers.

Bozarslan, Hamit (2003). "Kurdish Historiographic Discourse in Turkey," in Essays on the Origins of Kurdish Nationalism edited by Abbas Vali, Costa Mesa: Mazda Publishers.

Breuilly, John (2001). "The State and Nationalism" in Understanding Nationalism edited by Montserrat Guibernau and John Hutchinson, Cambridge: Polity Press.

Brown, David (1989). "Ethnic Revival: Perspectives on State and Society," Third World Quarterly, 14 (4): 1-16.

Brown, Sarah Graham (1999). Sanctioning Saddam: The Politics of Intervention in Iraq, New York: I. B. Tauris.

Brubaker, Rogers (1996). Nationalism Reframed: Nationhood and the National Question in the New Europe, Cambridge: Cambridge University Press.

Brubaker, Rogers (2002). "Ethnicity without Groups," Archives Européenes de Sociologie, 43 (2), 163-189.

Burhan Ghalion: There is No Such Thing as Syrian Kurdistan. Rudaw, April 17, 2012.

Cafiero, Giorgio. "The Dreams and Dilemmas of Iraqi Kurdistan," Foreign Policy in Focus, January 24, 2012.

Cafiero, Giorgio. "Who will Govern Syrian Kurdistan?," Foreign Policy in Focus, August 31, 2012.

Calhoun, Craig (1997). Nationalism, Minneapolis: University of Minnesota Press.

Çalışlar, Oral (1993). Öcalan ve Burkay'la Kürt Sorunu (The Kurdish Problem with Öcalan and Burkay), Istanbul: Pencere Yayınları. 
Çandar, Cengiz (2013). “On Turkey's Kurdish Question: Its Roots, Present State, Prospects," in Understanding Turkey's Kurdish Question edited by F. Bilgin, A. Sarıhan, Maryland: Lexington Books.

Çandar, Cengiz, “Turkey’s Kurdish Initiative May Affect Syria’s Kurds,” Al Monitor, 14 April, 2013.

Çandar, Cengiz. "Kürtler Yolsuzluk Şaibesi Altındaki İktidara Omuz Verir mi?" (Would the Kurds Support a government Stained by Corruption Charges?) Radikal, February 21, 2014.

Çandar, Cengiz. "Öcalan's Message is Much More Than a Cease-fire," AlMonitor, March 24, 2013.

CIA. World Fact Book, October 4, 2012.

Ciment, James, The Kurds: State and Minority in Turkey, Iraq and Iran, New York: Facts On File, 1996.

Connor, Walker (1994). Ethnonationalism: The Quest for Understanding, Princeton: Princeton University Press.

Connor, Walker (April, 1972). "Nation-Building or Nation-Destroying?," World Politics, 24 (3), 319-355.

Connor, Walker (January, 1993). "The Politics of Ethnonationalism," Journal of International Affairs, 27: 1-21.

Cottam, Richard W. (1979), Nationalism in Iran: Updated through 1978, Pittsburgh: University of Pittsburgh Press.

Crisis in Syria emboldens country's Kurds. BBC News Middle East, July 27, 2012. http://www.bbc.co.uk/news/world-middle-east-19021766 (Accessed October 19, 2012).

Dann, Uriel (1969). Iraq under Qassem: A Political History, London: Pall Mall.

Dawisha, Adeed (2005). "The Prospects for Democracy in Iraq: Challenges and Opportunities," Third World Quarterly, 26 (4/5): 723-737.

Dawisha, Adeed (2009). Iraq: A Political History from Independence to Occupation, Princeton, NJ: Princeton University Press.

Dawoody, Alexander (2006). "The Kurdish Quest for Autonomy and Iraq's Statehood," Journal of Asian and African Studies, 41 (5-6): 483-505. 
Day, Graham, Thompson, Andrew (2004). Theorizing Nationalism, New York: Palgrave Macmillan.

Demir, Eyüp (2005). Yasal Kürtler (Legal Kurds), Istanbul: Tevn Yayınları.

Democratic Principles Working Group (2002). Final Report on the Transition to Democracy in Iraq, Washington D. C.

Dilip, Hiro (1987). Iran under the Ayatollahs, New York: Routledge.

Dinçer, O. Bahadır. "The Kurds in Syria, the PKK and Turkey," The Journal of Turkish Weekly, August 16, 2012.

Dissident Leader Says Plight of the Iranian Kurds Little Known in the West. Rudaw, June 15, 2012.

Don't Provoke Us, Erdoğan Says in Stern Warning to Syrian Kurds. Today's Zaman, July 26, 2012.

Eagleton, William (1963). The Kurdish Republic of 1946, London: Oxford University Press.

Eccarius-Kelly, Vera (2011). The Militant Kurds: A Dual Strategy for Freedom, New York: Praeger.

Entessar, Nader (1992). Kurdish Ethnonationalism, London: Lynne Rienner Publishers.

Entessar, Nader (2007). "The Kurdish National Movement in Iran since the Islamic Revolution of 1979" in The Evolution of Kurdish Nationalism edited by Mohammed M. A. Ahmed, Michael Gunter, Costa Mesa, CA: Mazda Publishers.

Epözdemir, Şakir (2005). Türkiye Kürdistan Demokrat Partisi: 1968/235 Antalya Davasl Savunmasl (Kurdistan Democratic Party of Turkey: 1968/235 Antalya Lawsuit Defense), Istanbul: Peri Yayınları.

Eppel, Michael (2004). Iraq from Monarchy to Tyranny: From the Hashemits to the Rise of Saddam, Florida: University Press of Florida.

Ercan, Harun (2013). "Talking to the Ontological Other: Armed Struggle and the Negotiations between the Turkish State and the PKK," Dialectical Anthropology, 37 (1): 113-122.

Farhi, Farideh (March, 2005). "Crafting a National Identity amidst Contentious Politics in Contemporary Iran," Iranian Studies, 38 (1): 7-22. 
Farhi, Farideh (Summer 2005). "What Does the Ninth Presidential Election Say About Iranian Politics?" in Middle East Program Occasional Paper Series, Iran After the June 2005 Presidential Election, Woodrow Wilson International Center for Scholars.

Farouk-Sluglett Marion, Sluglett, Peter (2001). Iraq since 1958: From Revolution to Dictatorship, London: I. B. Tauris.

Fırat, Bahar Şahin, Fırat, Mesut (2011). 'Kürt Hareketi'ni Diyarbakır Cezaevi'ne Hapsetmek: Iktidar, Özne ve Siyaset Üzerine Eleştirel Bir Deneme" (Confining the Kurdish Movement to Diyarbakir Prison: A Critical Essay on Power, Agent and Politics), Toplum ve Kuram, 5: 93-105.

Frye, Richard N. (1968). Persia, London: George Allen and Unwin Ltd.

Galbraith, Peter (2006). The End of Iraq: How American Incompetence Created a War Without End, New York: Simon and Schuster.

Gamson, W. A., Meyer, D. S. (1996). “Framing Political Opportunity” in Comparative Perspectives on Social Movements: Political Opportunities, Mobilizing Structures, and Cultural Framings edited by Doug McAdam, John D. McCarthy, Mayer N. Zald, Cambridge, Cambridge University Press.

Gauthier, Julie (2009), "The 2004 Events in al-Qamishli: Has the Kurdish Question Erupted in Syria?" in Demystifying Syria edited by Fred H. Lawson, London: Saqi Book.

Geertz, Clifford (1973). The Interpretation of Cultures: Selected Essays, New York: Basic Books.

Gellner, Ernest (1964). Thought and Change, Chicago: The University of Chicago Press.

Gellner, Ernest (1997). "The Turkish Option in Comparative Perspective" in Rethinking Modernity and National Identity in Turkey edited by S. Bozdoğan, R. Kasaba, Seattle and London: University of Washington Press.

Ghajar, Shayan. "Iran's Minorities Look to Greens for Equal Rights," http://www.insideiran.org/critical-comments/iranpercentE2percent80percent99sminorities-look-to-greens-for-equal-rights/ (Accessed March 22, 2013).

Ghassemlou, A. R. (1981). Report of the Central Committee to the Fifth Congress of the Kurdistan Democratic Party of Iran, Paris: PDKI.

Ghassemlou, A. R. (1993). "Kurdistan in Iran" in A People without a Country: The Kurds and Kurdistan edited by Gerard Chaliand, New York: Olive Branch Press. 
Gheissari, Ali, Nasr, Vali (2006). Democracy in Iran: History and the Quest for Liberty, Oxford: Oxford University Press.

Giddens, Anthony (1985). A Contemporary Critique of Historical Materialism. Vol. 2. The Nation State and Violence, Cambridge: Polity Press.

Güneş, Cengiz (2007), "Kurdish Politics in Turkey: A Question of Identity," The International Journal of Kurdish Studies, 21 (1/2): 17-36.

Güneş, Cengiz (2012). The Kurdish National Movement in Turkey: From Protest to Resistance, London and New York: Routledge.

Gunter, Michael (2000). “The Continuing Kurdish Problem in Turkey after Öcalan's Capture," Third World Quarterly, 21 (5): 849-869.

Gunter, Michael (Summer 2013). "Reopening Turkey's Closed Kurdish Opening," Middle East Policy, 20 (2): 88-98.

Gunter, Michael. (2011). "Arab-Kurdish Relations and the Future of Iraq," Third World Quarterly, 32 (9): 1623-1635.

Gunter, Michael (2008). The Kurds Ascending: The Evolving Solution to the Kurdish Problem in Iraq and Turkey, New York: Palgrave Macmillan.

Hakk1, Majid (December, 2008). "Kurdish language in the Iranian Legal Framework", Kurdish Issue in Iran: Journal of Ghasemlou Center for Research and Political Development, Issue.

Hakk1, Majid (December, 2008). "The Political System and Kurdish Question in Iran", Kurdish Issue in Iran: Journal of Ghasemlou Center for Research and Political Development, Issue 1.

Hassan, Hussein D. (May, 2007). Iran: Ethnic and Religious Minorities. CRS Report for Congress, Public Broadcasting, Boston, MA.

Hassanpour, Amir (1994). "The Nationalist Movements in Azerbaijan and Kurdistan, 1941-46" in A Century of Revolution: Social Movements in Iran edited by John Foran, Minneapolis: University of Minnesota Press.

Helfgott, Leonard M. (1980). "The Structural Foundations of the National Minority Problem in Revolutionary Iran," Iranian Studies, 13 (1-4): 195-204. 
Hevra: Devrimci Türkiye Kürtleri Örgütü (Organization of Revolutionary Turkish Kurds) (1974). Türkiye Şartlarına Ters Düşen Bir Tez: Milli Demokratik Devrim (A Thesis that Runs Counter to the Conditions in Turkey: National Democratic Revolution). Zurich: Ronahi Yayınları.

Hicks, Elahé Sharifpour, Hicks, Neil (2007). "The Human Rights of Kurds in the Islamic Republic of Iran" in Kurdish Identity: Human Rights and Political Status edited by Charles G. MacDonald, Carole A. O’Leary, Florida: University Press of Florida.

Higgins, Patricia J. (1984). "Minority-State Relations in Contemporary Iran," Iranian Studies, 17 (1): 37-71.

Hobsbawm, Eric (1990). Nations and Nationalism since 1780: Program, Myth, Reality, Cambridge: Cambridge University Press.

Hoff, Ruud, Leezenberg, Michiel, Miller Peter (1992). Elections in Iraqi Kurdistan: An Experiment in Democracy, Brussels: Pax Christi International.

Hossino, Omar, Tanır İlhan (March, 2012). "The Decisive Minority: The Role of Syria's Kurds in the Anti-Assad Revolution," A Henry Jackson Society Report.

Houston, Christopher (2003). Islam, Kurds and the Turkish Nation State, Oxford and New York: Berg.

Human Rights Watch (2002). Human Rights Watch World Report 2002.

Human Rights Watch. "Iran: Security Forces Kill Kurdish Protesters”, August 11, 2005.

Human Rights Watch. "Iran: Freedom of Expression and Association in the Kurdish Regions”, January 9, 2009.

Human Rights Watch. "Iraqi Kurdistan: Growing Effort to Silence Media," May 24, 2011.

Hutchinson, John (1987). The Dynamics of Cultural Nationalism: The Gaelic Revival and the Creation of the Irish State, London: Allen \& Unwin.

Ichijo, Atsuko, Uzelac, Gordana (2005). When is the Nation? Towards an Understanding of Theories of Nationalism, New York: Routledge.

İmset, İsmet (1992). The PKK: A Report on Separatist Violence in Turkey, Ankara: Turkish Daily News Publications.

International Crisis Group. "Iraq and the Kurds: Confronting Withdrawal Fears," ICG Middle East Report 103, March 28, 2011. 
International Crisis Group. "Syria Under Bashar: Domestic Policy Changes", February 11, 2004.

International Crisis Group. "Turkey: The PKK and a Kurdish Settlement," Europe Report No. 219, September 11, 2012.

International Crisis Group. "Iraq's Constitutional Challenge," Baghdad and Brussels: ICG Middle East Reports 19, November 13, 2003.

International Crisis Group. "Syria's Kurds: A Struggle within a Struggle", Middle East Report No. 136, Brussels, Belgium, January 22, 2013.

Interview with Syrian President Bashar al-Assad, The Wall Street Journal, January 31, 2011, http://online.wsj.com/article/SB10001424052748703833204576114712441122894 (Accessed April 27, 2011).

Iran Human Rights Documentation Center (April, 2012). On the Margins: Arrest, Imprisonment and Execution of Kurdish Activists in Iran Today.

Iranian Kurdish Parties KDP, KDPI Meet for First Time since 2006 Split. Rudaw, December 14, 2012.

Iranian Opposition Slams Limitations on Use of Minority Language in Schools. January 19, 2013. http://en.irangreenvoice.com/article/2013/jan/19/3914 (Accessed April 24, 2013).

Jabary, Kawa, Hira, Anil (Summer 2013). "The Kurdish Mirage: A Success Story in Doubt," Middle East Policy, 20 (2): 99-112.

Jongerden, Joost (2007). The Settlement Issue in Turkey and the Kurds: An Analysis of Spatial Policies, Modernity and War, Leiden and Boston: Brill.

Jongerden, Joost, Akkaya, A. H. (2011). "Born From the Left: The Making of the PKK," in Nationalism and Politics in Turkey: Political Islam, Kemalism and the Kurdish issue edited by Marlies Casier and Joost Jongerden, London and New York: Routledge.

Jongerden, Joost, Akkaya, A. Hamdi (2012). "The Kurdistan Workers Party and a New Left in Turkey: Analysis of the Revolutionary Movement in Turkey through the PKK's Memorial Text on Haki Karer," European Journal of Turkish Studies, 14: 2-17.

Jongerden, Joost, Akkaya, A. Hamdi (2014). "Confederalism and Autonomy in Turkey: The Kurdistan Workers' Party and the Reinvention of Democracy," in The Kurdish Question in Turkey: New Perspectives on Violence, Representation, and Reconciliation edited by Cengiz Güneş, Welat Zeydanlıŏglu, London and New York: Routledge. 
Jongerden, Joost, Akkaya, A. Hamdi. (2011). "The PKK in the 2000s: Continuity through Breaks," in Nationalism and Politics in Turkey: Political Islam, Kemalism and the Kurdish Issue edited by Marlies Casier, Joost Jongerden, London and New York: Routledge.

Kanan, Makiya (2003). “A Model for Post-Saddam Iraq," Journal of Democracy, 14 (3): $5-12$.

Kanat, Kılıç Buğra (2013). "Ending Ceasefires for Political Survival: The Use of Diversionary Strategies by the PKK Leadership" in Understanding Turkey's Kurdish Question edited by F. Bilgin, A. Sarıhan, Maryland: Lexington Books.

Kashani-Sabet, Firouzeh (2002). "The Evolving Polemic of Iranian Nationalism" in Iran and the Surrounding World: Interactions in Cultural Politics edited by Nikki R. Keddie, Rudolph P. Matthee Seattle: University of Washington Press.

Katzman, Kenneth. "The Kurds in Post-Saddam Iraq," Washington, DC: Congressional Research Service, October 1, 2010.

Kavak, Şeref (2012). "Kürt Siyasetinin 2000'li Yılları: “Türkiyelileşme” ve Demokratik Toplum Partisi" (Kurdish Ethnopolitics in the 2000s: Turkey-fication and the Democratic Society Party) in Türkiye Siyasetinde Kürtler: Direniş, Hak Araylşı, Katıllm (Kurds in Turkish Politics: Resistance, Struggle for Freedom, Participation) edited by Büşra Ersanl1, Güney Göksu Özdoğan, Nesrin Uçarlar, İstanbul: İletişim Yayınları.

KDPI Leader: Agreement with Komala is Preparation for Collapse of Iranian Regime. Rudaw, September 5, 2012.

KDPI Program and Internal Regulations Adopted in the $13^{\text {th }}$ Congress, July 3-7, 2004. http://pdki.org/english/Program-and-internal-regulation/ (Accessed October 2, 2012).

Keles, Janroj, "Kurds in Syria and the Old Concept of "Good Kurds" and "Bad Kurds," Kurdistan Commentary, November 15, 2012.

Khorshidi, Majid, Zoeram, V. Amani Z, Fee, L. Yok, Jawan, Jayum A. (2011). "Politics of Ethnic Participation during Khatami's Presidency in Iran (1997-2004)," Canadian Social Science, 7 (4): 144-153.

Khoury, Ernest, "Stuck in the Middle: The Struggle for Syria's Kurds," Alakhbar, 23 March, 2012.

Kirişci, Kemal, Winrow, Gareth M. (1997). The Kurdish Question and Turkey: An Example of a Trans-state Ethnic Conflict, London: Frank Cass \& Co. Ltd. 
Kısacık, Raşit (2011). Kürt Sorunu ve Etnik Örgütlenmeler - 2: Rizgari ve Ala Rizgari (Kurdish Problem and Ethnic Organizations - 2: Rizgari and Ala Rizgari), Istanbul, Ozan Yayıncilik.

Kohn, Jerome (2007). "Preface: A Jewish Life: 1906-1975" in The Jewish Writings edited by Jerome Kohn and Ron H. Feldman, New York: Schocken Books.

Koohi-Kamali, Farideh (2003). The Political Development of the Kurds in Iran, New York: Palgrave Macmillan.

Koohi-Kamali, Farideh (2007) "The Kurdish Republic in Mahabad: Formation of a National Movement" in The Evolution of Kurdish Nationalism edited by Mohammed M. A. Ahmed, Michael Gunter, Costa Mesa, CA: Mazda Publishers.

Kurdish Parties of Iran Sign Cooperation Agreement. Ak News, August 22, 2012.

Kurdish Parties Walk Out of Syrian Opposition Conference in Cairo. Rudaw, July 5, 2012.

Kurdish Vote Contribute to Rouhani’s Victory in Iran. Rudaw, June 16, 2013.

Kurdistan (September, 1992). Organ of the Central Committee of Democratic Party of Iranian Kurdistan. no.189.

Kurds See Federalism as Best Solution for Syria. Rudaw, August 17, 2012.

KurdWatch (2009). "The Kurdish Policy of the Syrian Government and the Development of the Kurdish Movement since 1920", Report 1.

KurdWatch (December, 2009). "The Al-Qamishli Uprising: The Beginning of a New Era for Syrian Kurds", Report 4.

KurdWatch (December, 2011). "Who is the Syrian Kurdish Opposition? The Development of Kurdish Parties, 1956-2011," Report 8.

KurdWatch Newsletter. May 23, 2011. http://www.kurdwatch.org/newsletter/newsletter _en_230511.html (Accessed February 12, 2012).

KurdWatch. Interview with Salih Muslim Muhammad, Chairman of the PYD, November 8, 2011. http://kurdwatch.org/html/en/interview6.html (Accessed November 14, 2012).

KurdWatch. Interview with Azad Muhiyuddin, "The Kurdish Patriotic Conference is nothing more than a name. Compared to the PYD it has accomplished Nothing," March 21, 2012. http://www.kurdwatch.org/syria_article.php?aid=2484\&z=en\&cure $=240$ (Accessed June 21, 2012). 
KurdWatch. Interview with Salih Muslim Muhammad, Chairman of the PYD, November 8, 2011. http://kurdwatch.org/html/en/interview6.html (Accessed January 8, 2012).

Landis, Joshua, Pace, Joe (Winter 2006-2007). “The Syrian Opposition,” The Washington Quarterly, 30, (1), 45-68.

Lawrence, Quil (2008). Invisible Nation: How the Kurds Quest for Statehood is Shaping Iraq and the Middle East, New York: Walker \& Company.

Leezenberg, Michiel (2005). "Iraqi Kurdistan: Contours of a Post-Civil War Society," Third World Quarterly, 26 (4/5): 631-647.

Lowe, Robert (2007). "Kurdish Nationalism in Syria" in The Evolution of Kurdish Nationalism edited by Mohammed M. A. Ahmed and Michael Gunter, Costa Mesa, California: Mazda Publishers.

Lowe, Robert (2010). "The Serhildan and the Kurdish National Story in Syria," in The Kurdish Policy Imperative edited by Robert Lowe, Gareth Stansfield, London: Royal Institute of International Affairs.

Lowe, Robert, (January, 2006). "The Syrian Kurds: A People Discovered," Chatham House Briefing Paper, London.

Lund, Aron (May, 2012.) "Divided They Stand: An Overview of Syria's Political Opposition Factions," Foundation for European Progressive Studies, Uppsala, Sweden.

Mansour, Renad. "The Role of Iraqi Kurdistan in the Syrian-Kurd Pursuit of Autonomy," Aljazeera Center for Studies, September 19, 2012.

Marr, Phebe (1985). The Modern History of Iraq, Boulder, Colorado: Westview Press.

Massoud Barzani's Response to protests in Iraqi Kurdistan. Ekurd.net, February 27, 2011.

McAdam, D., McCarthy, J. D., Zald, M. N. (1996). Comparative Perspectives on Social Movements: Political Opportunities, Mobilizing Structures, and Cultural Framings, Cambridge: Cambridge University Press.

McAdam, Doug (1996). "Conceptual Origins, Problems, Future Directions" in Comparative Perspectives on Social Movements: Political Opportunities, Mobilizing Structures, and Cultural Framings edited by Doug McAdam, John D. McCarthy, Mayer N. Zald, Cambridge, Cambridge University Press.

McDowall, David (1996). A Modern History of the Kurds, London and New York: I. B. Tauris. 
Meeting Minutes of the Erbil Agreement, http://www.kurdwatch.org/pdf/KurdWatch_ D027_en_ar.pdf(Accessed September 16, 2012).

Meyer, David S. (2004). "Protest and Political Opportunities," Annual Review of Sociology, 30: 125-145.

Mohaddessin, Mohammad (1998). "The Myth of Moderation" in Foreign Affairs Committee of the National Council of Resistance of Iran, Iran Under Khatami: The Myth of Moderation, Auvers-sur-Oise, France.

Mohtadi, Abdullah, "The Kurds and the Green Movement," Frontline Tehran Bureau, http://www.pbs.org/wgbh/pages/frontline/tehranbureau/2010/06/the-kurds-and-the-greenmovement.html (Accessed March 22, 2013).

Mojab, Shahrzad, Hassanpour, Amir (1996). "The Politics of Nationality and Ethnic Diversity" in Iran After the Revolution: Crisis of an Islamic State edited by Saeed Rahnema, Sohrab Behdad, New York: I. B. Tauris \& Co Ltd.

Monshipouri, Mahmood, Assareh, Ali (2009). "The Islamic Republic and the Green Movement: Coming Full Circle," Middle East Policy, 16 (4): 27-46.

Moussavi Takes Political Risk and Condemns Kurdish Executions. May 11, 2010. http://insideiran.org/media-analysis/moussavi-takes-political-risk-and-condemns-kurdishexecutions/ (Accessed March 25, 2013).

Natali, Denise (2005). The Kurds and the State: Evolving National Identity, New York: Syracuse University Press.

Natali, Denise (2010). The Kurdish Quasi-State: Development and Dependency in PostGulf War Iraq, New York: Syracuse University Press, 2010.

Natali, Denise (Summer/Fall 2003). "The Kurdistan Region of Iraq: Stabilizer or Spoiler?," Georgetown Journal of International Affairs, 71-79.

Natali, Denise. “Syria’s Kurdish Quagmire,” AlMonitor, May 1, 2012.

Nezan, Kendal (1993). "Kurdistan in Turkey," in A People without a Country: The Kurds $\&$ Kurdistan edited by Gerard Chailand, New York: Olive Branch Press.

O'Leary, B., McGarry, J., Salih, K. (2005). The Future of Kurdistan in Iraq, Philadelphia: University of Pennsylvania Press.

O”Leary, Brendan, Salih, Khaled (2005). "The Denial, Resurrection, and Affirmation of Kurdistan" in The Future of Kurdistan in Iraq edited by Brendan O'Leary, John McGarry, and Khaled Salih, Philadelphia: University of Pennsylvania Press. 
Öcalan, Abdullah (1978). Kürdistan Devriminin Yolu (The Path to Kurdistan Revolution) (Manifesto), Weşanên Serxwebun, Köln.

Öcalan, Abdullah (1995). PKK 5. Kongresine Sunulan Politik Rapor (The Political Report Presented to the PKK $5^{\text {th }}$ Congress), Weşanên Serxwebun, Köln.

Öcalan, Abdullah (2000). Dönüşüm Süreci Üzerine Perspektifler: Politik Rapor (Perspectives on the Transformations Process: The Political Report), Weşanên Serxwebun, Köln.

Öcalan, Abdullah (2008). War and Peace in Kurdistan, Cologne: International Initiative Freedom for Öcalan - Peace in Kurdistan.

Öcalan, Abdullah (2011). Prison Writings: The PKK and the Kurdish Question in the $21^{\text {st }}$ Century, London: Transmedia Publishing Ltd.

Öcalan, Abdullah (1999). Declaration on the Democratic Solution of the Kurdish Question, London: Mesopotamian Publishers.

Öcalan's Historic Newroz 2013 Statement. March 24, 2013. http://peaceinkurdistancamp aign.wordpress.com/2013/03/24/Öcalans-historic-newroz-2013-statement/（Accessed January 8,2014$)$.

Olson, Robert (2005). The Goat and the Butcher: nationalism and State Formation in Kurdistan-Iraq since the Iraqi War, Costa Mesa, CA: Mazda Publishers.

On eve of Kurdish New Year, President Barzani delivers key address. March 21, 2012. http://www.krg.org/a/d.aspx?l=12\&s $=02010100 \& \mathrm{r}=223 \& \mathrm{a}=43432 . \& \mathrm{~s}=010000$ (Accessed November 11, 2013).

Özcan, Ali Kemal (2006). Turkey's Kurds: A Theoretical Analysis of the PKK and Abdullah Öcalan, New York \& London: Routledge.

Özcan, Nihat Ali (Spring 2004). "Could a Kurdish State Be Set Up In Iraq?," Middle East Policy, 11 (1): 119-122.

Özdağ, Ümit (2003). The PKK and Low Intensity Conflict in Turkey, Ankara: Frank Cass.

Özpek, B. B. (Summer 2012). "Democracy or Partition: Future Scenarios for the Future of Iraq," Insight Turkey, 14 (3): 127-140.

Pace, Joe, Landis, Joshua (2009). "The Syrian Opposition: The Struggle for Unity and Relevance, 2003-2008" in Demystifying Syria edited by Fred H. Lawson, London: Saqi Books. 
Park, Bill (2012). "Turkey, the US and the KRG: Moving Parts and the Geopolitical Realities," Insight Turkey, 14, (3): 109-125.

Party Program. Komala Party of Iranian Kurdistan. http://www.komala.org/english/ sidor/2011/Introduction_eindex.htm (Accessed October 3, 2012).

Paty Program. Party of Free Life of Kurdistan. http://pjak.org/eng/about.php (Accessed October 3, 2012).

PDKI participated in an Iranian opposition meeting in Prague. November 22, 2012. http://pdki.org/english/pdki-participated-in-an-iranian-opposition-meeting-in-prague/ (Accessed March 25, 2013).

Penrose, E. F., Penrose, Edith (1978). Iraq: International Relations and National Development, Boulder: Westview Press, 1978.

Perinçek, Doğu (1990). Abdullah Öcalan ile Görüşmeler, İstanbul: Kaynak Yayinları.

Phillips, Louise, Jørgensen, Marianna W. (2002). Discourse Analysis as Theory and Method, London: Sage Publications.

PKK ile organik değil ideolojik bağ var (There is an ideological, rather than an organic bond, with the PKK). BBC Turkish's Interview with the PYD leader Salih Muslim Muhammad. May 27, 2012. http:// www.radikal.com.tr/Radikal.aspx?aType=RadikalDet ayV3\&ArticleID=1095199\&CategoryID=81_(Accessed September 22, 2012).

Political Statement of the Iraqi Opposition Conference in London. December 14-16, 2002. http://www.kurdmedia.com/article.aspx?id=8850 (Accessed November 20, 2013).

Pollock, David, "Syria's Kurds Unite against Assad, but Not with Opposition”, The Washington Institute for Near East Policy, July 31, 2012.

President Barzani: We don't threaten the unity of Iraq; it is dictatorship that threatens the unity of Iraq. May 8, 2012. http:/www.malpress.com/english/news/302-presidentbarzani-we-dont-threaten-the-unity-of-iraq-it-is-dictatorship-that-threatens-theunity-ofiraq.html. (Accessed June 4, 2012).

Princeton University Iran DataPortal http://www.princeton.edu/irandataportal/elections/ (Accessed September 14, 2012).

PUK Falls to Third Place in Iraqi Kurdistan Elections. Al-Monitor, September 27, 2013.

PYD Leader Salih Muslim: Syrian Government Has Lost Control in Kurdish Areas. Rudaw, July 10, 2012. 
Qadir, Kemal Said (2007). “Iraqi Kurdistan’s Downward Spiral,” Middle East Quarterly, 14 (3): 19-26.

Rafaat, Araam (Fall 2007). "An Independent Kurdish State: Achievable or Merely a Kurdish Dream?” The Journal of Social Political and Economic Studies, 32 (3): 267-304.

Ramazani, Roullah (1975). "The Autonomous Republic of Azerbaijan and the Kurdish People's Republic: Their Rise and Fall," in The Anatomy of Communist Takeovers edited by Thomas Hammond, New Haven: Yale University Press.

Reaction to the Events of Kurdistan in Persian Publications (June 1993). Compiled and published by the KDPI, no.7.

Rouhani Comments in Iran Surprise Kurds, Other Minorities. Rudaw, July 4, 2013.

Romano, David (2006). The Kurdish Nationalist Movement: Opportunity, Mobilization and Identity, New York: Cambridge University Press.

Romano, David (2010). "Challenges of Autonomy in the Wake of U.S. Withdrawal," International Affairs, 86 (6): 1345-1359.

Rouhani Wins Iran's Presidential Election. Al Jazeera, June 15, 2013.

Sadjadpour, Karim (Summer 2005). "The Iranian Street in the Post-Khatami Era," in Middle East Program Occasional Paper Series, Iran After the June 2005 Presidential Election, Woodrow Wilson International Center for Scholars.

Salih Muslim Muhammad: Western Kurdistan Could Be a Model for a Free and Democratic Syria. Press Release, May 7, 2013, London.

Salih, Khaled (Spring 2004). "Kurdish Reality in an Emerging Iraq," Middle East Policy, 11 (1): $122-126$.

Serxwebun, Monthly periodical of the Central Committee of the PKK, October 1995.

Shaffer, Brenda (2002). Borders and Brethren: Iran and the Challenge of Azerbaijani Identity, Cambridge, Mass.: MIT Press.

Shemirani, Khosrow. "Vaqaye'-e Khuzestan az manzar-e hoquq-e bashari-hava siasatmadaran" (Events in Khuzestan from the viewpoint of human rights activists and politicians) Shahrvand, May 6, 2005.

Sicker, Martin (1988). The Bear and the Lion: Soviet Imperialism and Iran, New York: Praeger. 
Smith, Anthony (1998). Nationalism and Modernism, New York: Routledge.

Smith, Anthony (1999). Myths and Memories of the Nation, Oxford: Oxford University Press.

Stansfield, G., Anderson, E. (2010). Iraqi Kurdistan: Political Development and Emergent Democracy, London and New York: Routledge.

Stansfield, G., Anderson, L. (Spring 2009). "Kurds in Iraq: The Struggle between Baghdad and Erbil," Middle East Policy, 16 (1): 134-145.

Stansfield, Gareth (2005). "Governing Kurdistan: The Strengths of Division" in The Future of Kurdistan in Iraq edited by Brendan O'Leary, John McGarry, Khaled Salih, Pennsylvania: University of Pennsylvania Press.

Stansfield, Gareth (2007). Iraq: People, History, Politics, Cambridge: Polity Press.

Stansfield, Gareth (2010). "From Civil War to Calculated Compromise: The Unification of Kurdistan Regional Government in Iraq" in The Kurdish Policy Imperative edited by Robert Lowe, Gareth Stansfield, London: Chatham House.

Stansfield, Gareth, Ahmadzadeh, Hashem (2008). "Kurdish or Kurdistanis? Conceptualizing Regionalism in the North of Iraq" in An Iraq of Its Regions: Cornerstones of a Federal Democracy edited by Reidar Visser, Gareth Stansfield, New York: Columbia University Press.

Syria Update: Kurds give ultimatum to Syrian Security Forces. Rudaw, July 21, 2012.

Syrian National Council Mission and Program http://www.syriancouncil.org/en/missionstatement.html (Accessed October 25, 2012).

Syrian National Council, National Charter: The Kurdish Issue in Syria. http://www.syriancouncil.org/en/issues/item/620-national-charter-the-kurdish-issue-insyria.html (Accessed November 8, 2012).

Tahiri, Hussein (December, 2008). "Kurdish Nationalism in Iran: A Reassessment," Kurdish Issue in Iran: Journal of Ghasemlou Center for Research and Political Development, Issue 1.

Talabani acknowledges protesters and MP vote on their demands. Ekurd.net, March 18, 2011.

Tanır, İlhan, Van Wilgenburg, Wladimir, Hossino, Omar (2012). "Unity or PYD Power Play? Syrian Kurdish Dynamics after the Erbil Agreement," Henry Jackson Society Report. 
Taşpınar, Ömer (2005). Kurdish Nationalism and Political Islam in Turkey: Kemalist Identity in Transition, London and New York: Routledge.

Tavakoli-Targhi, Mohamad (1990). "Refashioning Iran: Language and Culture during the Constitutional Revolution," Iranian Studies, 23 (1/4): 77-101.

Tejel, Jordi (2009). Syria's Kurds: History, Politics, and Society, New York: Routledge.

Tezcur, G. Murat. (2009) "Kurdish Nationalism and Identity in Turkey: A Conceptual Reinterpretation," European Journal of Turkish Studies, 10: 2-18.

The Cultural Situation of the Kurds. European Union Parliamentary Assembly, July 7, 2006. http://assembly.coe.int/main.asp?Link=/documents/workingdocs/doc06/edoc 11006.htm (Accessed October 11, 2011).

The main Iranian Kurdish Party speaks to the Green Movement. Medya News, January 21, 2010.

Yekiti Party Program http://yekiti-media.org/nuce.php?z=\&id=33\&z=en (Accessed February 8, 2013).

Tilly, Charles (1978). From Mobilization to Revolution, Reading, PA: Addison-Wesley.

Tohidi, Nayereh (2009). "Ethnicity and Religious Minority Politics in Iran" in Contemporary Iran: Economy, Society, Politics edited by Ali Gheissari, Oxford: Oxford University Press.

Tripp, Charles (2007). A History of Iraq, New York: Cambridge University Press.

Turgut, Hulusi (1969). Barzani Dosyası (Barzani File), Istanbul: Hasmet Matbaas1.

Ünver, H. Akın (December, 2010). “Turkey's Kurdish Initiative: What Went Wrong? (Or dit it?)," Turkish Policy Center Reports.

Vali, Abbas (1998). “The Kurds and Their 'Others': Fragmented Identity and Fragmented Politics", Comparative Studies of South Asia, Africa and the Middle East, 18 (2): 82-95.

Vali, Abbas (2003). "Genealogies of the Kurds: Constructions of Nation and National Identity in Kurdish Historical Writing" in Essay on the Origins of Kurdish Nationalism edited by Abbas Vali, Costa Mesa, California: Mazda Publishers.

Vali, Abbas (2011). Kurds and the State in Iran: The Making of Kurdish Identity, London \& New York: I. B. Tauris \& Co Ltd. 
Vali, Abbas. Washington Kurdish Institute Conflict Resolution Forum, July 28, 1998, http://www.kurd.org/kcrf/ValiKCRF.html (Accessed December 23, 2011).

Van Wilgenburg, Wladimir, "Syrian Rebels and Kurdish Group Sign Truce," Rudaw, November 5, 2012.

Vanly, Ismet Chériff (1992). "The Kurds in Syria and Lebanon" in The Kurds: A Contemporary Overview edited by Philip G. Kreyenbroek, Stefan Sperl, London \& New York: Routledge.

Vanly, Ismet Sheriff (1993). "Kurdistan in Iraq" in A People without a Country: The Kurds and Kurdistan edited by Gerard Chaliand, New York: Olive Branch Press.

Views differ on PUK-KDP Agreement, Kurdish Globe, August 8, 2007.

Visser, R., Standfield, G. (2007). Iraq of Its Regions: Cornerstones of a Federal Democracy?, New York: Columbia University Press.

Visser, Reidar (2008). "Two Regions of Southern Iraq," in An Iraq of Its Regions: Cornerstones of a Federal Democracy edited by Reidar Visser, Gareth Stansfield, New York: Columbia University Press.

Von der Osten-Sacken, Thomas (March, 2006). "Working Paper: Iraqi Kurdistan; a Model for Iraq?" Presented to the ASPEN Conference: Greater Middle East, Doha, Qatar.

Watts, Nicole F (2007). "Silence and Voice: Turkish Policies and Kurdish resistance in the mid- $20^{\text {th }}$ Century" in The Evolution of Kurdish Nationalism edited by Mohammed M. A. Ahmed and Michael Gunter, Costa Mesa, CA: Mazda Publishers.

Watts, Nicole F. (2010). Activists in Office: Kurdish Politics and Protest in Turkey, Seattle, WA: University of Washington Press.

Watts, Nicole F. (2012). "The Role of Symbolic Capital in Protest: State-Society Relations and the Destruction of the Halabja Martyrs Monument in the Kurdistan Region of Iraq," Comparative Studies of South Asia and the Middle East, 32 (1): 70-85.

Weiss, Michael, "Syrian Kurd Leader: Revolution Won't Succeed Without Minorities," Interview with Dr. Abdulhakim Bashar, Chairman of the Kurdish National Council, The Atlantic, January 20, 2012.

Weiss, Michael, "Why Syria's Kurds Will Determine the Fate of the Revolution," The New Republic, November 16, 2011.

Weiss, Stanley. "It's Time for an Independent Kurdistan," Huffington Post, November 5, 2012. 
White, Paul (2000). Primitive Rebels or Revolutionary Modernizers? The Kurdish National Movement in Turkey, London: Zen Books.

Wimbush, S. Enders (1979). "Divided Azerbaijan: Nation Building, Assimilation, and Mobilization between Three States" in Soviet Asian Ethnic Frontiers edited by William O McCagg, Brian D. Silver, New York: Pergamon Press.

Worth, Robert F. "Kurds Turn Violent in Protest against Their Leaders," The New York Times, March 16, 2006.

Yavuz, Hakan (Spring 2004). "Provincial Not Ethnic Federalism in Iraq," Middle East Policy, 11 (1): 126-131.

Yavuz, M. Hakan, Özcan, N. Ali (Spring 2006). "The Kurdish Question and Turkey's Justice and Development Party," Middle East Policy, 13 (1): 102-119.

Yeğen, Mesut (1999). "The Kurdish Question in Turkish State Discourse," Journal of Contemporary History, 34 (4): 555-568.

Yeğen, Mesut (2007). "Turkish Nationalism and the Kurdish Question," Ethnic and Racial Studies, 30 (1), 119-151.

Yıldı, Kerim, Taysi, Tanyel B. (2007). The Kurds in Iran: The Past, Present and Future, London: Pluto Press.

Yüce, M. Can (1999). Doğuda Yükselen Güneş I, Istanbul: Zelal Yayınları. 
VITA

\section{OZUM YESILTAS}

Born, İzmir, Turkey

2001

B.A., Sociology

Middle East Technical University

Ankara, Turkey

2005

M.S., European Studies

Middle East Technical University

Ankara, Turkey

2006

M.S. International Relations

Middle East Technical University

Ankara, Turkey

2007-2010

Graduate Teaching Assistant

Florida International University

Miami, Florida

2010-2014

Ph.D. Candidate

Florida International University

Miami Florida

Adjunct Instructor

Florida International University

Miami, Florida

\section{ACADEMIC AND PROFESSIONAL CONFERENCE PRESENTATIONS}

Yesiltas, Ozum (June, 2013). A Non-Arab Spring: Syria's Kurdish Predicament. Paper presented at the Peace Science Society-International Studies Association Joint Conference, Budapest, Hungary.

Yesiltas, Ozum (April, 2013). Reinterpreting Ethnic Nationalism and Democratization: The Kurdish Experience. Paper presented at the International Studies Association Annual Conference, San Francisco, CA.

Yesiltas, Ozum (November, 2012). The Role of Ethnic Movements in the Formation of a Democratic Iran. Paper presented at the Middle East Studies Association Annual Meeting, Denver, CO. 